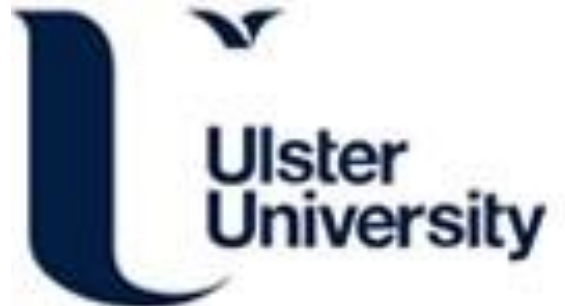

\section{Strengthening nursing, midwifery and allied health professional leadership in the UK - a realist evaluation}

Ryan, A., Jackson, C., McBride, T., Manley, K., Dewar, B., Young, B., \& Roberts, D. (2021). Strengthening nursing, midwifery and allied health professional leadership in the UK - a realist evaluation. Leadership in Health Services, 34(4), 392-453. https://doi.org/10.1108/LHS-11-2020-0097

Link to publication record in Ulster University Research Portal

\section{Published in:}

Leadership in Health Services

Publication Status:

Published (in print/issue): 21/09/2021

DOI:

10.1108/LHS-11-2020-0097

\section{Document Version}

Author Accepted version

\section{General rights}

Copyright for the publications made accessible via Ulster University's Research Portal is retained by the author(s) and / or other copyright owners and it is a condition of accessing these publications that users recognise and abide by the legal requirements associated with these rights.

\section{Take down policy}

The Research Portal is Ulster University's institutional repository that provides access to Ulster's research outputs. Every effort has been made to ensure that content in the Research Portal does not infringe any person's rights, or applicable UK laws. If you discover content in the Research Portal that you believe breaches copyright or violates any law, please contact pure-support@ulster.ac.uk. 


\section{Leadership in Health Se}

Strengthening Nursing, Midwifery and Allied Health Professional Leadership in the UK- a realist evaluation

\begin{tabular}{|r|l|}
\hline Journal: & Leadership in Health Services \\
\hline Manuscript ID & LHS-11-2020-0097.R2 \\
\hline Manuscript Type: & Original Article \\
\hline Keywords: & $\begin{array}{l}\text { Transformational Leadership, nurses, midwives, allied health } \\
\text { professionals, Leadership, realist evaluation, appreciative inquiry }\end{array}$ \\
\hline \multicolumn{2}{|l}{} \\
\hline
\end{tabular}

\section{SCHOLARONE \\ Manuscripts}




\section{Strengthening Nursing, Midwifery and Allied Health Professional Leadership in the UK: a realist evaluation \\ Authors:}

Carolyn Jackson *, Director ImpACT Research Group, Associate Professor Practice Transformation, Faculty of Medicine and Health Sciences, University of East Anglia, Norwich Research Park, Norwich

Tamsin MacBride, University of the West of Scotland, High Street, Paisley, PA1 2BE

Professor Kim Manley CBE, Professor of Practice Development, Co-Director ImpACT Research Group, Faculty of Medicine and Health Sciences, University of East Anglia, Norwich Research Park, Norwich. Emeritus Professor Practice Development, Canterbury Christ Church University, Canterbury, Kent

Professor Belinda Dewar, Co-Director My Home Life International, Director Wee Culture, Scotland.

Beverley Young, Senior Lecturer, Post Graduate Research School Lead, School of Health and Life Sciences, UWS Lanarkshire Campus, Stephenson Place, Hamilton International Technology Park, South Lanarkshire G72 OLH

Assumpta Ryan, Professor of Ageing and Health, Institute of Nursing and Health Research, University of Ulster, Londonderry, Northern Ireland BT48 7JL

Professor Debbie Roberts, Director of School of Nursing and Allied Health, Faculty of Health, Liverpool John Moores University, Liverpool L2 QP.

${ }^{*}$ Corresponding Author

\section{Funding}

This study was conducted in 2018-2019, funded by a research grant from the Burdett Trust for Nursing in the UK. 
39 Acknowledgements

40 We are extremely grateful for the detailed feedback provided by Dr Cathy Sharp (Research 41 for Real) and Dr Katie Shearn (Sheffield Hallam University) which has helped shape this 42 article.

43 The research team would like to thank the invaluable contributions from the Project Advisory 44 Board who have supported the project team with critical review and ideas, namely:

45 University of the Third Age

46 University of South Wales

47 Queens Nursing Institute

48 Northern Ireland Government/NHS Scotland

49 Deirdre Munro, Founder Global Village midwives \& researcher, Eire

$50 \quad$ NHS Improvement, England

51 East Kent Hospitals NHS Foundation Trust 52 


\section{Abstract \\ 54 Purpose}

55 This paper shares the findings of a realist evaluation study that set out to identify how to 56 strengthen nursing, midwifery and allied health professions (NMAHP) leadership across all 57 health care contexts in the UK conducted between 2018-2019. The collaborative research 58 team were from the Universities of Bangor, Ulster, University of the West of Scotland and 59 Canterbury Christ Church University.

\section{Design}

61 Realist evaluation and appreciative inquiry were used across three phases of the study. 62 Phase 1 analysed the literature to generate initial programme theories (IPTs) about what 63 works, tested out in Phase 2 through a national social media twitter chat and sense making 64 workshops to help refine the theories in Phase 3. Cross cutting themes were synthesised 65 into a leadership framework identifying the strategies that work for practitioners in a range of 66 settings and professions based on the context, mechanism and output (CMO) configuration of 67 realist evaluation. Stakeholders contributed to the ongoing interrogation, analysis and 68 synthesis of project outcomes.

\section{Results}

70 The study generated 3 initial programme theories and five Guiding Lights of leadership that 71 enable and strengthen NMAHP leadership across a range of contexts in addition to a 72 leadership impact framework, and 360 feedback and reflection tool to aid leadership 73 development in the workplace.

\section{Originality/value}

75 The realist evaluation with additional synthesis from key stakeholders has provided new 76 77 knowledge about the principles of effective NMAHP leadership in health and social care, presented in such a way that facilitates use of the 5 guiding lights to inform future practice, education, research and policy development.

79 Classification of Article: Original Research.

80 Keywords: Transformational leadership, nurse, midwifery, allied health professions 81 leadership, realist evaluation, appreciative inquiry.

82 


\section{Introduction}

This paper presents the findings of a three-phase study which aimed to strengthen nursing, midwifery and allied health professionals' (NMAHP) leadership practice in the UK across a range of practice based contexts. The study, funded by The Burdett Trust, intended to identify what NMAHP leadership strategies work, why and for whom. The outcome was five 'guiding lights', a metaphor describing the salient features of leadership that reflect a strong relationship and value-based approach relevant to contemporary health and social care. The term 'guiding lights' has been coined in preference to 'simple rules' used by other researchers when translating complex insights or findings into principles based on realist reviews undertaken by Best et al. (2012) and Plsek and Wilson (2001). The project also created a vision for the future of leadership through a narrated visual presentation at https://hml.helix.uws.ac.uk/Play/17172, a leadership impact framework and 360 degree feedback tool to facilitate practitioner self-reflection and assessment.

Over the past couple of years there has been a noticeable philosophical shift in understanding about how leadership impacts on culture, quality, safety, staff and patient experience in health and social care (Cardiff et al., 2020; Manley and Jackson 2020; Manley et al., 2019). This shift has prompted debate about the need to identify what works well in both formal leadership programmes as well as in workplace teams and organisations. It is especially important in a pandemic world that NMAHP leadership contributions are visible and valued in all international contexts and literature (Duignan et al., 2020; Bell and Colleran, 2018). UK evaluations of leadership programmes (Hocking et al., 2020; University of Manchester 2017) are heavily weighted towards the NHS, exclude social care and do not identify i) what difference they make in practice longitudinally, ii) whether there is any cost benefit for system investment, iii) what impact they have on reducing workforce inequalities, or on improving patient and staff outcomes. The purpose of this paper is to contribute to this debate by presenting the principles for strengthening nurse, midwifery and allied health professionals' leadership distilled through the lens of a realist evaluation and appreciative inquiry approach.

\section{Aim of the Study and Research Questions}

The study aimed to identify the enablers, processes and indicators that nurse, midwife and allied health professional leaders use to achieve and demonstrate impact and embed innovative practices across different contexts (clinical care, environment of care, social care $\&$ education, organisations, communities and multi-professional teams), addressing four specific research questions:

1. What are the enablers required for NMAHP leaders to achieve impact and embed innovation in different contexts?

2. What are the processes that NMAHP leaders use to achieve impact and embed innovation in different contexts?

3. What are the indicators of effectiveness of leaders in different contexts?

4. What are the indicators of outcome that demonstrate impact and embed innovation in different contexts? 
128 The research team had expertise in realist review methods, appreciative inquiry, practice 129 improvement, practice development, clinical and systems leadership and were based across 130 the UK with a link University in each of the four countries. An advisory board comprising 131 national nursing, midwifery and allied health professional leaders from England, Northern 132 Ireland, Scotland, Wales and Eire provided additional expertise across practice, education, 133 research and strategic contexts and acted as a peer review group auditing the development 134 of the guiding lights framework and associated tools.

135 In this study, the literature was interrogated as a data set to generate tentative programme 136 theories to evaluate and synthesize what leadership strategies work, as opposed to identifying 137 what the gaps are. We briefly outline here our contemporary understanding of leadership 138 theory in order to make our assumptions and definition of leadership clear in the theoretical 139 framework section below. It is important for us to distinguish here that our study focused on 140 contemporary theories of transformational leadership as opposed to management practices. 141 Management we identify as having a focus on the delivery of organisational tasks carried out 142 in the best possible way to achieve organisational goals that are appropriately resourced 143 (finance, human resources) and meet the needs of the organisation. The main aim of 144 management is the achievement of order and consistency (stability), through planning, 145 organisation, directing or guiding, and supervising and monitoring activities (Gopee and 146 Galloway, 2017). Kouzes and Posner's theory of transformational leadership (1987) on the 147 other hand, defines leadership as a set of five observable, learnable practices: challenging 148 familiar processes, inspiring a shared vision, enabling people to act in accordance with their 149 vision, modelling the way through living shared values, and encouraging others by recognising 150 and celebrating success. For our team, transformational leadership is a relationship-based 151 leadership approach associated with positively improving the workplace and its culture at 152 different levels across the system, with impact on quality and safety outcomes for both 153 healthcare users as well as staff (Bogh Andersen et al., 2018; Boamah et al., 2018; Manley et 154 al., 2019; Tomlinson 2012; Manley et al .,2011; Wang et al., 2011; Mullen and Kelloway; 2009).

\section{Literature Review}

156 Health and social care systems are complex because of dynamic changing inter-relationships 157 characteristic of open systems (Greenhalgh \& Papoutsi 2018). The pandemic poignantly 158 demonstrated this, with every part of the system experiencing unforeseen consequences due 159 to change in other parts (Jackson et al., 2021). A great deal of the published literature 160 assumes that leadership happens within 'a stable, albeit complicated, arrangement of 161 individual elements ' rather than a dynamic, ecological system that is multi-facetted and 162

164 The key challenge facing all NHS organisations is to nurture cultures that ensure the delivery 165 of continuously improving high quality, person centered, safe and compassionate care (West 166 et al.,2015). Leadership is the most influential factor in shaping organisational culture so 167 ensuring the necessary leadership behaviours, strategies and qualities are developed is 168 fundamental (Manion et al., 2005). The literature cites three contemporary views of leadership 169 needed for the $21^{\text {st }}$ century which move away from focusing on the individual qualities and 170 skills of leaders: 
172 i) greater emphasis on collective leadership which embraces collective capability and

173

174

175

176

177

178

179

180

181

182

183

184

185

186

187

188

189

190

191

192

193

194

195

196

197

198

199

200

201

202

203

204

205

206

207

208

209

210

211

212

213

214

215

216

217 endeavour when acting and learning together to shape the culture (Manley et al., 2019; Sharp 2018; McAuliffe et al., 2017; West et al., 2014 and West et al., 2015);

ii) distributed leadership with a shared distributive and adaptable focus, not just across organisations but also across boundaries and systems (Endres and Weibler, 2020; Beirne, 2017; West et al., 2015); and,

iii) social leadership which recognises that social capital is embedded in people with different expertise working together through social movements, connected relationships and networks (Stodd, 2016).

There is clear evidence of the link between leadership and a range of important outcomes within health services, including patient satisfaction, patient mortality, organisational financial performance, staff well-being, engagement, turnover and absenteeism, and overall quality of care (West et al., 2015). Using theory to guide research into leadership in health care is vital to ensure the concepts and constructs the research seeks to address are both appropriate and the most relevant. However, there is a reported preponderance of weak study designs in health care leadership research (Wong et al., 2013), which include small sample sizes; lack of underpinning theory; survey instruments with inadequate reliability and validity; failure to measure important control variables; cross sectional designs; reliance on self-report (e.g. for measuring patient safety); and poor measurement of leadership (not systematic), all of which make it difficult to draw more wide-ranging conclusions about the processes by which leadership affects key outcomes, in terms of moderators or mediators.

Wong et al., (2013) conducted two systematic literature reviews of nursing leadership and patient outcomes, which identified 20 articles of good methodological quality (research design, sampling, measurement, and statistical analysis). Of these, only nine were based on an explicit leadership theory. Transformational leadership theory is to date the most influential theory guiding health care leadership research. In their review Wong et al. (2013) found six out of the nine articles were influenced by transformational leadership theories (Bass \& Avolio, 1994; Kouzes \& Posner, 1995). Other theories identified included authentic leadership (Wong et al., 2013), and servant leadership theories (Nagel \& Andenoro, 2012). Positive effects of transformational leadership are cited as work-life balance, staff well-being, positive nursing outcomes, patient safety, openness about errors, and patient and staff satisfaction (Kvist et al. 2013; Wong et al., 2013). Authentic leadership emphasises the importance of building leader legitimacy through honest relationships which foster trust with followers by valuing their contributions and behaving ethically and transparently. Trust then leads to engagement and improved individual and team performance. Wong et al., (2010) found nurses who reported higher levels of authentic leadership in their managers also reported a greater level of trust, work engagement and perceptions of quality of care. Wong et al., (2013) found positive relationships between authentic leadership and managerial trust, working life, and patient outcomes. Moreover, authentic leaders supported and encouraged nurse empowerment in their roles and this empowerment led to improvements in job performance.

Leadership types, styles and experience impact on teamwork and team culture (Cardiff et al., 2020; Manley et al., 2019; Manley et al., 2011). The use of different leadership styles continues to be recognised as relevant to different situations, particularly when creating the conditions through relationships for enabling individuals, teams, organisations and more widely, communities to become empowered or in situations that require a more transactional style, for example in the context of emergencies and safety (Fynes, et al., 2014). 


\section{Theoretical Framework of Effective Leadership underpinning the Study}

220 Our theoretical framework of effective leadership is informed by four key theories. Firstly, 221 complex adaptive systems theory that explains the interrelationships and interdependence across systems and the few simple rules that guide local development of the 21st-century healthcare (Plsek, 2001). Secondly the theory of transformational leadership and the importance of developing leadership expertise and skills at every level of the health and social care system to support transformation (Manley and Jackson, 2020; Manley et al., 2019; Manley et al., 2018; Martin and Manley; 2017). Effective leadership is embodied in compassionate relationship centred values, key to enabling empowerment of bottom-up teams and creative solutions to sustainable system change that is person-centred (Manley and Jackson 2020; Dewar et al ., 2017; Dewar and Cook, 2014). Leadership expertise in the form of authentic enabling relationships is required for developing collective direction across boundaries, to grow others as leaders, and to enable transformation to happen in every part of the system as well as across it. (Dewar et al., 2017a; Dewar and Cook 2014). Leadership skills for supporting sustainable person-centred transformation are recognized at three levels: micro, meso, and macro (Manley and Jackson, 2020). Transformational leadership across these levels characterize quality clinical leaders, facilitators, and reflect the tenets of Kouzes and Posner's (1995) model of leadership practices modelling the way; inspiring a shared vision; challenging the process; enabling others to act; and encouraging the heart. Transformative leaders are compassionate, collaborative, visible and use positive language, building trust and recognise good work - this changes how others around them behave, react and respond (West et al., 2015). Through learning from and building on what went well, leaders nurture a safety culture that minimises the occurrence of harm (Hollnagel et al., 2015). Finally the theory of relationship centered practice (Dewar and Cook, 2014) emphasizes that appreciative approaches build on what works, and are a powerful strategy for countering the negativity that impairs readiness to change supports self-organising change processes that generates new ideas, new ways of thinking and collective ambition. (Cardiff et al., 2020; Dewar et al., 2017; Sharp et al., 2017; Watkins et al.,2016).

These four leadership theories were based on our paradigmatic/underpinning philosophy /epistemology/ontological stances. The focus on transformational and facilitative leadership

250 informed a movement from individual leadership behaviours to collective action and cocreation, but also a focus on adaptability and complexity further endorsed by complex adaptive systems theory. There is very little published evidence of systems approaches to leadership and transformation so this study offers important insights into how NMAHP leaders can be 254 more influential in supporting and leading system integration for the future to meet the health and social care needs citizens globally.

There follows an explanation of the study design, methodology and methods used.

\section{Study Design}

\section{Methodology}


263 The study design was based on principles associated with realist evaluation methodology 264 (Emmel et al., 2018; Wong et al., 2016; Dalkin et al., 2015; Pawson and Tilley, 2004; Pawson, 265 2006) and appreciative inquiry (Cooperrider et al., 2008; Dewar and MacBride, 2017; Sharp 266 et al., 2017. Appreciative inquiry (Al) aims to create new lenses (knowledge, models and/ or 267 theories) for looking at old issues (Bushe and Kassam, 2005). It is a move away from 268 traditional 'problem-solving' approaches (problem identification followed by solution 269 implementation). The focus is on stakeholder engagement and dialogue, identifying strengths 270 and positives through provocative questioning so that 'what might be' can emerge; these are 271 considered more powerful generators of momentum and sustainable change (Cardiff et al., 272 2020). This basis for the research implied a need to engage with NMAHP leaders who were 273 willing to share their experiences and ideas in helping to shape a contemporary practice driven 274 view of what works and does not work in different practice contexts. The appreciative focus 275 framed the questions asked in the study design and in the realist evaluation methods used in 276 Phase 2 and 3 of the study.

277 Realist evaluation is a theory-based approach to evaluation enabling the use of mixed278 methods to explore the research question of interest. It is being increasingly applied to the 279 evaluation of complex social programmes that involve human decisions and actions as it seeks 280 to provide an in-depth understanding of what works, for whom, in what contexts and why things 281 work. A central tenet of realist methodology is that programs work differently in different 282 contexts therefore taking account of contexts is important (Wong et al., 2016). Realist 283 evaluation enables the generation of initial programme theories (IPTs) that provide more 284 detailed explanation and insight into strategies that work in practice. A realist programme 285 theory specifies which outcomes are linked to the intervention, what mechanisms generate 286 the outcomes and what features of the context affect them (Emmel et al., 2018). The realist 287 approach explores the relationship between the context, mechanisms and outcomes and the 288 configurations ('CMOCs'; i.e., $\mathrm{C}+\mathrm{M}=\mathrm{O}$ ) that are uncovered become part of an explanatory 289 initial programme theory (IPT) to be tested and refined. The function of the IPT is to describe 290 and explain as far as possible how and why the programme (NMAHP leadership) may be 291 working for some people and not others, depending on which mechanisms are or are not 292 triggered in specific contexts (De Brun and McAuliffe, 2020). These chains of inference enable 293 the exploration of generative causation, by explicitly linking the triggering of mechanisms to 294 contextual conditions and specific outcomes (Davidoff et al., 2015). Through elicitation of the 295 patterns of CMOCs that are evident across settings it is possible to establish the NMAHP 296 leadership CMOCs that operate as the common thread across various contexts (De Braun 297 and McAuliffe, 2020).

298 The realist evaluation process starts with the construction of an initial programme theory (or 299 theories) on how and why an intervention/programme/policy is thought to work. These are 300 then (repeatedly) applied, reviewed and refined to (eventually) produce a realist programme 301 theory that describes which contexts, combined with which mechanisms, produce particular 302 outcomes for specified groups (Wong et al., 2016). The Rameses II reporting standards for 303 realist evaluation research (Wong et al., 2016) guided the conduct of our work. Since 304 programmes work differently in different contexts and through different mechanisms, 305 programmes cannot simply be replicated from one context to another and automatically 306 achieve the same outcomes. Theory-based understandings about 'what works, for whom, in 307 what contexts, and how' are, however, transferable (Wong et al., 2016). 
308

309

310

311

312

313

314

315

316

317

318

319

320

321

322

323

324

325

326

327

328

329

330

331

332

333

334

335

336

337

338

339

340

341

342

343

344

345

346

347

348

Figure $\mathbf{i}$ illustrates the relationship between Context, Mechanisms and Outcomes in the research process.

$<$ Insert Figure | $>$

To our knowledge, this is the first study of NMAHP leadership that combines realist evaluation with appreciative inquiry to explore why and how NMAHP leadership interventions operate to trigger mechanisms that lead to certain outcomes. Recent publications have used qualitative mixed methods evaluation to explore clinical academic careers for the NMAHP workforce (Miller et al., 2020; Coad et al., 2019) and realist evaluation has been used to evaluate the impact of collective leadership on team working and safety culture in health care teams (De Brun et al .2020, De Brun and MacAuliffe, 2020).

\section{Methods}

The study comprised three interrelated phases using mixed methods of data collection (Table I). At the start of the study, terms of reference, definitions, inclusion and exclusion criteria were discussed and agreed to ensure a shared understanding within the team to inform the literature review and research processes.

<Insert Table I: Study Design>

\section{Ethical approval}

Ethical approval was achieved through University Ethics at Canterbury Christ Church University (Ref 17/H\&W/24C). A full application through the National Health Service's Integrated Research Application System (IRAS ID/2234444) was additionally completed but was deemed unnecessary by them when reviewed. Informed consent for participation in the social media twitter chat was provided through a nomination strategy and participants were advised that we would be thematically analysing the data for research purposes to generate initial programme theories.

\section{Phase 1: Interrogation of the literature to generate tentative programme theories}

Phase 1 involved interrogating the literature using a realist evaluation approach to generate insights between contexts, mechanisms and outcomes that would inform the development of initial programme theories about what works, in what context and for whom, regarding leadership in NMAHP contexts. Realist evaluation recognises the restrictions with a fixed search protocol and instead utilises an iterative approach which begins with a broad aim which is progressively refined during the review of the literature (Pawson et al., 2005; Pawson, 2006).

The search strategy was collaboratively discussed, developed and refined by the study team. Two members of the study team focused on searching, sourcing and identifying relevant literature and in collaboration with the team refined the search strategy using an iterative approach for the lifetime of the study. In addition, working in partnership with the team, 
349 identification of key authors in the field of leadership, seminal papers, secondary sources and 350 grey literature informed and shaped the review of the literature. In the realist review literature value is placed on all types of evidence that can answer any part of the review question - then using this evidence to corroborate or refute emerging programme theories

The search strategy (Figure II) included: Soclndex, and Health Source: Nursing/Academic Edition databases. Search terms included nurse leadership combined with impact, culture, practice, education, organisation, policy and education.

364 Due to the vast amount of literature retrieved on an initial search using the terms health professionals and allied health professionals, a decision was made to confine the search to 366 nursing only and to build on this through seeking contributions on relevant allied health professional literature from the advisory board members and other stakeholders from the social media and workshop elements of this study. Following removal of duplicates; titles, abstracts and reference lists were reviewed and pertinent secondary sources added to the review. This is an important process as premise of realist review is to err on the side of inclusion to avoid omitting data that could contribute to programme theory development (Rycroft-Malone et al., 2012). This process generated a total of 132 papers to be included in the review which were then subjected to three levels of iterative analysis to develop some tentative programme theories about leadership strategies that work. Wong et al. (2013) discuss the necessity to 'contain' a review as it has potential to go in many different directions. The review was therefore 'contained' in the sense that it focussed on nursing leadership in all contexts as exploring other midwifery and allied health professional contexts was not practicable within the given timeframe. However, grey literature for midwifery and allied health professional contexts was additionally reviewed at the end of this phase. The themes

380 emerging from the review were analysed thematically to generate a refined CMO table linked 381 to the literature themes.

382 In the first level analysis of the literature a framework was developed to support data extraction

383 focused on identifying the context, mechanisms and outcomes (CMO) that described what 384 leadership strategies work, in what context and for whom in every context from each of the 385132 papers identified. An example is provided in Table II.

390 Often outcomes were implicit, with very few studies presenting theoretical insights to the relationship between contexts, mechanisms and outcomes. Most papers highlighted factors 392 that could tentatively contribute to insights across different contexts, mechanisms and 393 outcomes of NMAHP leadership rather than specific middle range theories. Middle range 
394 theories focus on a narrow dimension of the leadership practice reality and often attempt to 395 describe, explain, or predict certain phenomenon in clinical practice (Smith and Liehr, 2008).

396 The synthesis of the literature from the CMO tables for the 3 broad cross-cutting themes and 397 hypotheses identified the contexts and mechanisms that contributed to both process 398 outcomes and ultimate outcomes for different stakeholder groups. Using the idea of 399 developing "simple rules" from the emergent findings (Plsek \& Wilson, 2011; Best et al., 2012); 400 the analysis of the CMO configuration identified common cross cutting themes which informed 401 the basis of broad principles which nurse leaders may use to achieve impact and embed 402 innovative practices across different contexts. At this initial stage, the three cross-cutting 403 themes reflecting three initial programme theories for testing were identified as: 1) Authentic 404 relationships and connections $(\mathrm{C} 1), 2)$ Transformational leadership linked to collective 405 leadership and social capital $(\mathrm{C} 2,3,4)$, and 3) Supporting everyone to have a voice in complex 406 and changing contexts $(C 5,6,7,8,13)$.

407 For each of these themes the context mechanisms and outcomes were identified at micro408 meso and macro levels of the health and care system to identify what works, how it works and 409 for whom. This distillation was intended to identify the essence of what the themes were about 410 in a way that would help nurses, midwives and allied health professionals to easily remember 411 and apply general principles of leadership practice in their everyday work. This process was 412 informed by a large reputable Canadian study which used realistic evaluation to explore large 413 systems transformation (Best et al., 2012). This approach had previously been identified as a 414 way of focusing on middle range theories that can inform ways of thinking and being, where 415 these were referred to as 'simple rules' and a way of working with complexity to aid decision416 making (Plsek, 2001; Plsek and Wilson, 2011). To strengthen the quality of a review, Wong 417 et al. (2013) emphasise the need to have a detailed audit trail of iterative processes and draw 418 upon external stakeholder expertise. Whilst the supplementary literature table identifies the 419 CMO factors distilled from the full literature review, here we present an excerpt of the second 420 level analysis of the literature, to illustrate the audit trail for the development of CMO 421 relationships for cross cutting theme 1 authentic relationships and connections (C1).

422

<Insert Table III: Illustration of second level analysis CMO relationships in relation to NMAHP leadership derived from interrogating the literature for cross cutting theme Authentic Relationships and Connections>

426 In Table III it is possible to see that the literature identified that contexts that develop NMAHP 427 leaders who can build and nurture authentic, caring \& successful relationships with 428 individuals, those important to them, staff and stakeholders (C1) enable staff to feel valued 429 and supported (O1), experience an increased self awareness, sense of empowerment (O2) 430 and self confidence to speak up (O3), as well as strengthened more compassionate and 431 respectful relationships (O4). This in turn impacts on outcomes that improve staff wellbeing, 432 reduce stress and emotional exhaustion (O5), improve staff morale and satisfaction (O6) and 433 improve the quality of leadership so that it is more compassionate, inclusive and valued by 434 others (O7). At a team and service user level, this impacted on enhanced team effectiveness 435 and learning culture (O8), staff engagement and healthy safe workplace cultures (O9). The 436 following mechanisms were identified from the second level analysis of the literature as being 437 crucial behaviours for creating these outcomes: 
461

462

463

464

465

466

467

468

469

470

471

472

473

474

475

476

477

478

479

480

481

- Facilitating caring, compassionate civil conversations, caring reflections and practices (M1).

- Leaders are authentically present building ethical, trusting relationships where people feel safe to speak up (M2).

- Leaders develop appreciative, mutual learning relationships with all and nurture these in others (M3).

Further the literature identified the importance of leaders being able to connect emotions (M4), using different opportunities through powerful inquiry-based questions to promote conversation-based change (M5). Their ability to enable self and situational awareness in others through self assessment, inquiry, self motivation, self-compassion, self-reflection for learning and role clarity (M6).was a powerful mechanism for enabling others to learn, grow and flourish.

Each of the three cross cutting themes were then distilled into a more condensed version as CMO configurations that separated out intermediate and ultimate outcomes, using all the theme titles for CMOs from the second level analysis (any embellishments in the titles (in green) came from a second round of literature analysis F1-F32. This was relevant literature that previously did not come up in the first literature review which focused mainly on nursing , explained earlier, and embraced AHPs (including what was suggested by advisory board) and more general research and theoretical insights. Table IV provides an illustration of the further development of cross cutting theme 1 authentic relationships and connections which was later shared with workshop participants.

$<$ Table IV Illustration of Cross Cutting Theme 1 Authentic Relationships and Connections further refined in preparation for presentation to workshop participants>

As part of the study, there was a planned and comprehensive approach to test out theoretical development with external stakeholders. Leaders from a diverse range of health and social care contexts within the four countries of the UK were invited to workshops from social media events on Twitter (\#Strengthening, the hashtag used for the twitter chat) and through professional networks and an advisory board. These activities also asked leaders to consider the cross-cutting themes which had been developed and discuss the processes and indicators they use to achieve and demonstrate impact and embed innovative practices. These are described in Phase 2 and 3 below. The stakeholders (advisory board and workshop participants) were invited to contribute to the ongoing refinement of three tentative programme theories arising from the integrative literature review and reflected in three sets of $\mathrm{CMO}$ relationships.

\section{Phase 2- Social Media Twitter Chat}

Phase 2 was used to test out and add to our initial programme theories and themes generated from Phase 1 with senior NMAHP leaders and practitioners across the UK. Twitter was used to help support nomination of NMAHP leaders in practice, education, research and strategy/policy contexts who we could invite to the sense making workshops and/or have further dialogue around our emergent analysis. Additionally, this phase served to generate other insights about leadership, particularly in the midwifery and allied health care professional 
482 contexts to complement the lower inclusion of these areas in the literature. This process was 483 informed by a recently developed UK-wide Social Media research strategy for health care 484 research that draws on the unique selling points of 'rapidity of access' and 'scale of consensus' 485 to engage health professionals and key stakeholders.

486 (https://hartsofthepossible.wordpress.com/about/).

487

Two one-hour twitter chats were advertised through all professional bodies and networks in each of the four countries of the UK. Across the 2 twitter chats held on the $11^{\text {th }}$ and $19^{\text {th }}$ July 2018 there were 199 participants sending 998 tweets with 4.035 million social media impressions. Of the 199 participants, 26 were AHPs holding senior leadership positions as Professors, Professional Leads, Clinical Fellowships in University, policy, workforce, government departments, professional bodies and practice contexts. Twenty-one participants held senior nursing leadership positions as Professors, Policy Leaders, Directors of Nursing, Senior Advisors, and Consultant Practitioners in University, government departments, global think tanks and practice settings. Thirty-one participants held Midwifery leadership positions as Professors, Lead Midwives and social entrepreneurs in University, global think tanks and practice settings. The remaining 121 participants were front line NMAHP practitioners from across the UK. The two transcripts of each twitter chat were printed off and turned into a manuscript. Each line of tweet entry was numbered and retweets highlighted as repetition of a key message that participants felt very important. The transcripts were then subjected to a content analysis drawing out the key words and phrases that could be used to test out and interrogate the language used in the guiding light document to ensure that language used was practical and grounded in the real world so that it would be readily understandable and used by practitioners in practice and others less familiar with professional leadership terms. The analysis was completed by two members of the research team independently. Table $\mathrm{V}$ illustrates an excerpt for Guiding Light 1 of how the themes generated from the Twitter Chat were used to populate a table testing out our IPT and guiding lights, and providing supportive evidence from practice for:

i) Identifying leadership attributes useful for developing a 360-degree assessment tool.

ii) Impact of leadership experienced by them that had a significant impact on their own leadership behaviours and practices.

iii) Leadership processes perceived as most influential in working with others.

iv) More general impacts on developing followers, teams, evidencing impact in practice and on strategic thinking.

\section{<insert Table $\mathrm{V}$ example of national twitter chat for guiding light $1>$}

Table $V$ illustrates that Guiding Light 1, focused on working towards or building authentic caring relationships was a core finding from the literature review and the data generated through the workshops and twitter chat. Leadership attributes identified as most influential in the twitter chat were themed as:

1. Approaching, personable, compassionate and generous.

2. Sparkle, authentic, relaxed and passionate.

3. Are able to observe, listen and are non-judgemental. For twitter chat participants the impact of this kind of leadership on themselves was identified as being encouraged to follow their own passion and in thinking about modelling the way, that they are a real person. The leadership processes identified as being most influential were 
529 connecting in a way that makes everyone feel special and being authentic and true to your 530 values. These twitter chat comments and themes helped to reinforce the findings from the 531 workshops and the literature review to inform development of Guiding Light 1 and the other 532 guiding lights in the framework.

\section{Phase 3- Exposure of IPTs and Guiding Lights for further critique and/or validation}

\section{National Sense Making Workshops}

537 This phase focused on bringing a range of key stakeholders together for sense making 538 workshops. The work was complemented by the professional networks known to each UK 539 country lead in the project team. The workshops in each country focused on presenting and 540 getting further critique of the three IPTs, generated from the CMO relationships as well as 541 engaging with future perspectives through participants' shared leadership stories and 542 collaborative critique. Participants were self-identified from the twitter chat complemented by 543 professional networks known to each country's lead in the project team. Table VIII 544 summarises the number of participants involved. In total there were 61 participants of which 54528 were nurses, 9 midwives, 18 allied health professionals and 6 University of the Third Age 546 reflecting a citizen contribution.

547

<Insert Table VI Summary of Participants in the National Workshops>

The workshops used the creative methods of appreciative framing and dialogue in order to promote collaborative sensemaking of the data presented as the draft IPTs, CMOs and Guiding Lights. In this context, sensemaking is understood as a social process where meaning is 'negotiated, contested and mutually co-constructed' (Maitlis and Christianson, 2014, p 66). This can springboard action that might otherwise be impeded (Hultin and Mähring, 2017). The use of symbolic representation or imagery can help to deepen inquiry, to unleash latent, tacit or unconscious knowledge (Dewar, 2012; Sharp et al., 2018). A collaborative sensemaking tool developed by the LIFE programme (Sharp et al., 2017; Dewar, 2012) was used consisting of 12 images with words to promote generativity. Words are provocative prompts and thus have generative potential, provoking reflection or stimulating alternative dialogue, leading to new insights or thinking (Bushe and Marshak, 2016). The intention was to add a playful and experimental dimension to the workshops as this is at the heart of $\mathrm{Al}$ (Sharp et al., 2018). Each person explained why they had chosen a particular image or images and what feelings or thoughts that image had provoked in them in relation to NMAHP leadership. Figure III provides the composite of images chosen by participants and the conversations this sparked about leadership. Generally the feedback from the workshops

$568<$ Insert Figure III> Composite of images chosen by participants and the conversations this 569 sparked about leadership

\section{Analysis of the Data and Development of the Guiding Light}

571 A requirement for realist evaluation research is that data collection and analysis takes a 572 "retroductive" approach (Gilmore et al., 2019). Retroduction refers to "the identification of 573 hidden causal forces that lie behind identified patterns or changes in those patterns" (The 574 RAMESES II Project, 2017, p. 1). Retroduction uses both inductive and deductive reasoning 
575 and includes researcher insights to understand generative causation, by exploring the 576 underlying social and psychological drivers identified as influencing programme outcomes. 577 For retroduction to occur, it is important to have multiple data sources and incorporate one's 578 common sense to test and refine programme theories (PTs), (The RAMESES II Project, 2017, 579 p. 1).

580

The analysis phase comprised a synthesis of the data from Phases 1-3 and a purposeful discussion around which key theories influenced our synthesis based on our past experience and applied research as researcher-practitioners. This is an important principle in appreciative inquiry that requires researchers to be curious in asking questions of the data to focus on what is emergent in relation to what matters most to NMAHP leaders. These substantive theories were based on our values and beliefs about what we strive to understand as researchers, namely:

i) pragmatic aspects of contexts, relationships, what works and why this works through theorising from practice but building on what is known.

ii) how we want to be as researchers, that is; appreciative, transparent, authentic and collaborative; and,

iii) what counts as knowledge; recognising the interrelationship between contexts, complexity, actors and systems and that no knowledge is value free (Guba and Lincoln, 1994); and,

iv) developing knowledge with generative capacity (Gergen,1982) that challenges the status quo and creates a vision of what is possible.

597 The final distillation of the CMO relationships informing each of the 3 IPTs derived from 598 interrogating the literature and workshop dialogue are shared as a supplemental table 599 (Supplemental Table 2). The refinement of the CMO relationships from this integrative 600 literature review, the workshops and social media exercise led to further development and co601 creation of five "simple rules". (Plsek, 2001; Best et al., 2012). This included refining the 602 concept of simple rules to 'guiding lights' which acts as a set of principles to enable and 603 strengthen leadership within a range of contexts. Work in progress was presented to the 604 Advisory Board at key points in the project to ensure that there was sufficient external objective 605 review and critique of the development of the framework and guiding lights and that the audit 606 trail was clear.

607 <Insert Table VII: The Three IPTs and Guiding Lights>

608 The next section outlines each guiding light (Table VIII) and provides an overview of the 609 context and mechanisms that enable each guiding light to happen and their outcomes in 610 practice. The full Guiding Light framework is provided as Supplemental file 2. It is important 611 to emphasise that all guiding lights are interrelated, and, in our discussion, we present each 612 guiding light using the metaphor of light and aim to focus on a specific aspect of the principles 613 that we suggest enable and strengthen leadership across a range of contexts in nursing, 614 midwifery and allied health professional practice. Excerpts from the literature review and data 615 gathered from Phase 2 and Phase 3 of the study are integrated to illustrate supporting 616 evidence.

617 <Insert Table VIIII The Guiding Lights of NMAHP Leadership> 


\section{Findings}

619

620

As a result of the retroductive processes used in Phases 1-3 of the study five Guiding Lights of NMAHP Leadership were distilled for the three IPTs. These are presented here supported by evidence from stakeholders and supportive literature.

623

\section{The Five Guiding Lights of NMAHP Leadership}

\section{Guiding Light 1: "The Light Between Us as interactions in our relationships"}

627 Guiding light 1 emphasises the importance of giving attention to what is happening between 628 us when we are together. In response to a question about what makes a good leader, this 629 excerpt from the twitter chat illustrates the light metaphor as a catalyst for others.

630 'They sparkle with passion and authenticity and encourage others to act' (Twitter chat, 631 response 58)

632

633

634

635

636

637

638

639

640

641

642

643

644

645

646

647

648

649

650

651

652

653

654

655

656

657

658

659

660

661

662

Three contextual enablers identified were:

\section{1) Being authentic, working towards ensuring a space of civility}

'Civility is claiming and caring for one's identity, needs, and beliefs without degrading someone else's in the process....[Civility] is about disagreeing without disrespect, seeking common ground as a starting point for dialogue about differences, listening past one's preconceptions, and teaching others to do the same.' (Brown, 2017 citing Dahnke and Spath). Examples from the twitter chat that reinforce authenticity and civility include 'Leading humbly by example with respect and kindness' (T1 L85), being "inclusive and open to ideas (T2, L852) and 'supporting me with tough decisions' (T 1 L 162).

\section{2.) Careful listening}

Listening enables what is important to people to be heard and is the starting point for reflection, stretching our current thinking and innovating together. A "Willingness to listen" was a consistent theme generated in the workshops. Here one twitter chat participant explains the importance of "Being present and facilitate a safe space to listen, hear, learning, understand and fuel action of the journey" (T 1 L236).

\section{3.) Developing positive respectful relationships}

The realist evaluation identified a contextual focus on relational practices as a key principle to enabling and strengthening leadership (Cummings, 2010; Adamson et al., 2011; Dewar and Cook, 2014; Manley, 2014; Hewison and Morrell, 2014; Hannah, 2016; Dewar et al., 2017; Gotlieb, 2013). We have previously highlighted one of our underpinning substantive theories informing this study as being relationship centred care. The term relationship-centred care was first used by Tresolini and the Pew-Fetzer taskforce in 1994, who highlight the importance and centrality of relationships within healthcare. Tresolini and the Pew-Fetzer taskforce (1994) assert the foundation of high-quality care is on developing positive relationships not only between care provider and the person receiving care but with all those in the care process, that is, patient, staff members and relatives as well as communities. Whilst relationship centred practice has largely been discussed in the context of patient care (Nolan et al., 2006, 
663 Solkadaris et al., 2016), the findings from this review also highlighted a focus on relationships 664 as a key contextual enabler for strengthening leadership in health and social care. Workshop 665 participants identified that as NMAHP leaders "You succeed when you help others to 666 succeed..... Working in a place where 'I've got your back' rather 'than watch your back' as well 667 as the importance of "going the road less travelled - having the courage - what is the road? 668 Focussing deeply on relationships - one step at a time".

669 Three key mechanisms explain why a focus on building authentic caring relationships are 670 linked to having caring and civil conversations. The first mechanism is including different 671 methods, to focus moment by moment, on what matters to people (Dewar et al., 2017).

"We need to nurture talent enabling others to take supported risks and learn from outcomes that are not always as desired" (T1 454)

The second explains how caring relationships focus on encouraging and sustaining genuine curiosity and kindness for self and others (Peus et al., 2012; Dewar et al., 2017). This linked to the importance of civility as well as caring in these conversations.

"They are approachable and happy to hear other people's thoughts and perspectives" (T1 L318)

The third mechanism that enabled caring relationships was having a deep understanding of self - our vulnerability, strengths, weaknesses, aspirations and what keeps us healthy in those relationships (Akerjordat and Severensson, 2008; Peus et al., 2012). "Quiet determination, self-belief and absolute faith and determination are important in nurturing young talent building capacity and capability takes time" (T1 L 353)

This twitter chat participant identified the importance of a memorable leader that influenced their practice "Took time with me and shared their vulnerabilities' (T1 L95)

A focus on developing relationship with self, practicing self-compassion and building resilience all relate to emotional intelligence and the impact on the development of caring relationships.

690 Building emotional intelligence as such is a key ingredient in strengthening leadership which 691 leads to the final mechanism - working with and connecting with emotions (Akerjordet and 692 Severinsson, 2008; Dewar et al., 2017; Sharp, 2018). "They are wise, have great insight, can 693

694 Literature widely supports the value of emotional intelligence in enabling and strengthening 695 leadership, as a transformational leadership behaviour that enhances creativity and fosters 696 the development of positive workplace cultures (Gifford et al., 2018; Prezerakos, 2018).

697 Two outcomes result for all who are touched by this aspect of leadership

- it is experienced as compassionate and credible, authentic, caring and appreciative - underpinned by positive working relationships.

700 As this twitter chat participant explains" Leaders who connect with each individual, who are 701 willing to be authentic, true to their values and at the same time value the values of others. 702 (T2 L770) 
704 Guiding lights two and three relate to the extensive literature on transformational leadership

705

706

707

708

709

710

711

712

713

714

715

716

717

718

719

720

721

722

723

724

725

726

727

728

729

730

731

732

733

734

735

736

737

738

739

740

741

742

743

744

745

746

747

748

749

practices with a focus on collectively exploring multiple contributions and strengths to shape what people collectively want to happen. This is done through sharing stories and our hearts, motivating with passion, inviting inquiry and questions, admitting mistakes and celebrating successes. (Dewar et al. 2017a; Dewar et al. 2017b; Dewar and MacBride 2017; Gottlieb, 2013; Sharp, 2018; Soo Young, 2017).

\section{Guiding Light 2:' Seeing People's Inner Light and keeping it glowing'}

Seeing people's inner light is a metaphor for seeing each person's worth (including own), and cherishing the varied ways people connect, contribute and bring about change as illustrated by this comment in response to a question about when leadership is working well:

\section{'They see something in you that you do not immediately see in yourself' (Twitter chat response, 136).}

It is manifested through working with others, creating experiences of being safe to be authentic and share ideas and emotions. It is underpinned by three contextual enablers, with a focus on:

1) Creating the conditions of psychological safety (Edmonson and Lei, 2014) where people are clear about the positive consequences of voicing opinion, where people listen to understand and inquire together to explore shared meanings to help everyone to flourish and grow (Manley et al., 2011).

2) Valuing, spotting and drawing on multiple perspectives - including our own - and nurturing talents for change (Dewar et al., 2017a; Sharp, 2018); and,

"It's about helping you see the best you there is, helping you to stretch those boundaries and grow- not judging". (T2 L 855)

3) Seeking out, inquiring into and valuing the experiences of those who give and receive services provides the basis for exploring and learning together so that practice can be celebrated, and places value on a culture of continuous development (Dewar et al., 2017a; Sharp, 2018). This was described by one twitter chat participant as "They walk the talk, role modelling an inclusive approach that takes people on a journey, consistently questioning to promote learning opportunities" (T2 545)

\section{Guiding Light 3: 'Kindling the Spark of light and keeping it glowing'}

The metaphor for guiding light 3 builds on 'seeing the inner light'. 'Kindling the spark', and then, 'keeping it glowing' each demonstrate different subtleties. Kindling involves generating shared understanding of what lights people's fire and finding ways for people to get energy from each other's different light sources (priorities, values, beliefs, enabling them to come into their own - as described above). Keeping the light glowing when the light flickers involves 
750 helping ourselves and others to take risk and harness learning from disappointments

751

752

753

754

755

756

757

758

759

760

761

762

763

764

765

766

767

768

769

770

771

772

773

774

775

776

777

778

779

780

781

782

783

784

785

786

787

788

789

790

791

792

793

794

795

796

797

alongside delights, as represented by the following comment from the Twitter Chat.

'Spreading a baton of encouragement, creating a pandemic of positivity and kindness' (Twitter chat response, 105 )

Mechanisms that enable guiding light two and three to happen include building collective trust and respect (Gottlieb 2013; Soo Young, 2017; Sharp, 2018) enabling the development of relationships (Franks-Meeks, 2018); and creating a relational space where there is shared meaning about what matters to people (King's Fund, 2011; NHS Improvement, 2018; Sharp 2018).

"It is the ability to paint a compelling picture of the future and then chunk it up into bite sized chunks that people can see in relation to the whole picture" (T2 L593)

The second mechanism is actively seeking out multiple perspectives with a real desire to see the world through the eyes of others, recognising everyone is an expert of their own experience (National Improvement and Leadership Development Board, 2017; Soo Young, 2017; Sharp, 2018). This mechanism places value on cultures that place value on patient experience (Akhtar et al., 2016) and commitment to hearing a range of perspectives - for example patient stories - and using this evidence to inform practice (Dewar and Cook, 2014; Sharp, 2018). This links to a third mechanism that enables the exploration of contributions and strengths - by focussing on engagement (Davies, 2013, West et al., 2015, Akhtar et al., 2016) in different and creative ways enabling a blending of different types of knowledge (people's experience, research, policy etc) (Sharp, 2018). This reduces the hierarchy of knowledge where intuitive knowledge - knowledge generated from hearing stories about people's experience - has equal value to research knowledge (Sharp, 2018). The fourth mechanism is around openness to shared learning and willingness to take collective action which fosters shared accountability, shared decision-making, shared priorities and shared learning across teams, organisations and systems (Manley and Jackson, 2020; Cardiff et al., 2020, Kuluski and Guilcher, 2019). The fifth mechanism is around developing teams that can self-organise, moving from individual and heroic leadership models to that of shared, distributive and collective leadership (de Zelueta, 2016; Manley and Jackson, 2020; Cardiff et al., 2020, Sharp, 2018). As one participant identified, leaders are "those willing to see beyond hierarchy, see beyond the conditioned and traditional systems and challenge" (T2 L770)

The building of self- organising teams requires the fostering and sharing of knowledge, skills, and learning and creating the conditions where individuals feel safe to experiment and able to share mistakes so that new learning can be generated (Parker et al., 2015). Participants in the twitter chat talked about the importance of being 'Inclusive and open to ideas (T2 L 852)

"It's about helping you see the best you there is, helping you to stretch those boundaries and grow- not judging" (T2 L 855)

The outcomes of Guiding Lights 2 and 3 are that leadership is experienced as inclusive, collective, shared and distributive by all who are touched by it, thereby dispersing traditional views of leadership as something practiced only by hierarchical leaders. Additionally, there are also outcomes for staff and teams. Staff feel valued, supported, involved and heard, which leads to: 
- improved morale, commitment, wellbeing, staff satisfaction and retention, with reduced burnout, stress and exhaustion

- Improved confidence to speak up, self-awareness, and empowerment, contributing to increased skills, improved relationships, and career development.

Teams are recognised as healthy, effective and empowered with cultures of active learning, engagement, reflection and adaptation. This results in a strong team commitment to better practice, creativity, innovation and improving performance.

\section{Guiding Light 4: "Lighting up the known and the yet to be known”}

Guiding Light 4 illustrated by the metaphor of a lighthouse with its rotating light beam, reveals features illuminated, before plunging them into darkness as the beams passes by.

The lighthouse metaphor was chosen as a way of acknowledging that there are stable structures in health and social care contexts, but also unlit unknown places, the light illuminates both. The light beam represents our aspiration to be a source of steadiness during change by sharing information on what is known and stable. This may include shared foundation values, purpose and ways of working as well as recognising that we work and live in contexts that are complex, often unpredictable or are yet to be known as the COVID-19 pandemic has shown.

Complex adaptive systems theory accounts for changes in different parts of a system often having unintended and unanticipated consequences for other parts and recognises that its continual creativity is a natural state, as is a constancy between tension and balance (Plsek, 2001).

Complexity covers a spectrum of factors from relationships e.g. service users with complex health and social care needs (Hurlock-Chorostecki and McCallum 2016); turbulent and human complexities linked to power emotions and relationships (Sharp, 2018); inter- professional and ethical issues; the complexity of medical and biological, psychological and social, multiple pathways with a choice of destination - navigating through difficult terrain; being able to make sense of confusion and conflict (Manley et al., 2008); through to complexity generated by environments, the service, or the health and social system (NHS, 2017). Complex environments can lead to value conflicts with potential for moral distress (Morley et al., 2018; Morley et al., 2017).

Leadership in this guiding light involves showing a level of comfort when engaging with uncertainty - the unpredictability of the darkness; and valuing that which lights the way forward to be found in relationships that facilitate flexible and creative approaches. These approaches may differ from action plans, risk aversion strategies and hierarchical rules due to the relational aspect of NMAHP leadership.

The study identified two important contextual enablers:

1) Contexts that aspire to being a source of steadiness in the midst of change where information is shared on what is known and stable, and 
837 2) Contexts where there is a commitment to both pro-activity and adaptability that show a level 838 of comfort when engaging with uncertainty; and valuing that which lights the way forward.

839 'Leadership isn't easy, it's dangerous at times. It's stepping out of your comfort zone doing 840 the right thing, whilst bringing others with you' (Twitter chat response, 377)

841

842

843

844

These contexts support relationships which facilitate flexible and creative approaches that may differ from action plans, risk aversion strategies and hierarchical rules where instead minimum specifications yield more creativity than detailed plans (Cardiff et al., 2020; West et al., 2015). A number of mechanisms when combined with these two contextual factors explain leadership outcomes. One, identified explicitly in the workshops, as sharing our knowledge for leadership and innovation in a way that everyone can make sense of, in order to learn, share, innovate and create. This approach, experienced as supportive by staff is also understood as motivating, stimulating and facilitating reflection, learning and action for improvement, including risk taking that is also safe.

851

'Be present and facilitate a safe space to listen, hear, learning, understand and fuel action of the journey' (Twitter chat response, 236)

The outcomes of guiding light 4 are for people and organisations.

- People experience better healthcare outcomes, quality and satisfaction.

- Organisations demonstrate improvement in services, performance, safety and quality with healthy teams.

These organisational outcomes further the positive outcomes for patients, clients and service users; and also, staff through improved retention, stability, and commitment aligned with the qualities of a learning organisation.

865 Guiding Light 5 is about fostering ways of connecting to maximise possibilities for collective action. This requires responding to the unique nature of local context and practicing adaptability in order to tap into the distinctive riches on offer. Such an approach benefits the system and society through building social capital (Stodd, 2016), identified as a resource for system change; increasing resources available to people, organisations and communities for change; and ultimately improving population health. The constellation of stars metaphor is used as stars are individually brilliant sources of energy. When connected invisibly through electromagnetic forces holding them in constellations, they are awesome. This metaphor accentuates the power of collective leadership and collective action through tuning into local resources, networks, communities, and recognising where there is potential for enhanced futures. The following comment from the Twitter Chat illustrates this point:

'Power to interconnect ideas into a brand-new vision or concept'(Twitter chat response, 148)

Contextual enablers that underpin this guiding light include:

881 1) a commitment to fostering ways of connecting together which maximise the possibilities for 882 this collective action, and 
883 2) responding to the unique nature of the local context and practicing adaptability in order to 884 tap into the distinctive riches on offer.

885

886

887

888

889

890

891

892

893

894

895

896

897

898

899

900

901

902

903

904

905

906

907

908

909

910

911

912

913

914

915

916

917

918

919

920

921

922

923

924

925

926

927

Mechanisms that enable this to happen include the co-creation of systems/infrastructures and working together across these to share rich information about better practices. In order for this co-creation to flourish, there needs to be a good understanding of social network relationships among people within the organisation and those external to the organisation (Soo Young, 2017). In addition, the mechanism of building and using social capital through collaborative relationships and networks is key. Social capital exists in the active connections between people where trust, mutual understanding, shared values and behaviours link the members of human networks, making cooperative action possible. (Cardiff et al., 2020; Manley and Jackson 2020; Manley et al., 2019) . Developing these networks connects people to others from different backgrounds with a potentially different range of ideas and resources. This has the potential to open up new opportunities, span professional and social boundaries, and provide connections to useful resources such as knowledge, skills and new networks that may be beyond current networks.

Developing social capital emphasises adopting an open-systems mindset where emergence is valued and leveraging relational and interpersonal aspects of leadership development.

As one twitter chat participant identifies, it is "Definitely about being interested, knowing people, forming relationships and trust, saying what you mean and meaning what you say. You need to position yourself where you can look forwards and backwards" (T2 L 652)

Specific skills include the ability to identify tacit knowledge within individuals and networks, facilitating purposeful conversations, crafting insightful and curious questions to explore what is valued, working as coaches where sharing of learning builds collective energy which in turn leads to the creation and sharing of new understandings, engage others with compelling stories, building commitments and developing extended social networks (Soo Young, 2017). Statements that were made by twitter chat participants included the importance of influential NMAHP leaders having the "Power to interconnect ideas into a brand new vision or concept" (T1 L148) and "Seeing the world differently, free thinkers understanding the importance of co creation" (T1 157). "They are wise, have great insight, can alter their approach depending on the situation of people involved" (T1 158)

The potential impact of building social capital results in outcomes related to enhanced work motivation by increasing the sense of unity in an organisation, increased knowledge about resources available to people, organisations and communities for change, improving the organization's efficiency by promoting cooperation between individuals and groups and improved population health (Edmonstone, 2011; Soo Yong 2017).

\section{Implications for Practice}

The study has developed additional important resources to enable NMAHP leaders to demonstrate their leadership impact in a range of contexts through the Leadership Impact self -assessment framework (Figure III) which can be used for 360 feedback in the workplace using the appreciative assessment and reflection tool (Figure IV). Impact is defined as 'making 
928 a positive difference' to individuals, including, colleagues, providers or recipients of health care 929 or associated contexts, and the systems that support communities (NHS England, 2015).

930 The framework can be used for a number of different purposes, to:

931

932

933

934

935

936

937

938

939

940

941

942

943

944

945

946

947

948

949

950

951

952

953

954

955

956

957

958

959

960

961

962

963

964

965

- Self-assess for the purpose of guiding the practitioner in their professional and or career development.

- Demonstrate how the practitioner's leadership role contributes to or supports impact with others.

- Contribute to academic or professional accreditation and or professional revalidation.

- Facilitating continuing inquiry into the practitioner's own effectiveness of their leadership practice.

- Further development of leadership programmes that are based on sound theoretical principles.

The guiding lights are used to frame impact of leadership at three different levels- i) impact on self and others ;ii) impact on team(s)/ workplace(s); iii) impact on the system/communities, regionally, nationally or internationally.

\section{<insert Leadership Impact Framework Figure IV and Figure V 360 Reflective Tool >}

\section{Implications for Research, Policy and Education}

Firstly, it is important to acknowledge that this study has illuminated the a-theoretical nature of the relationships between contexts, mechanisms and outcomes in the existing leadership literature. There is more scope to develop the tentative programme theories developed in this study with NMAHP leaders in a variety of different contexts. The outcomes of leadership research mostly focused on staff outcomes and intermediate outcomes that are then linked to ultimate outcomes in both staff and patients (supplemental). More consideration needs to be given to the impact of leadership on patients, carers and their families.

Whilst policy makers note the increasing importance of leadership in facilitating the culture change needed to support health and care systems to adopt sustainable change at pace, there is still a prevailing focus on traditional approaches to individual leadership development as opposed to collective leadership across teams, services and systems. If we fail to understand how to transform leadership policy and education, then it will be impossible to support the workforce to adapt and flex to the increasingly complex contexts they are working in. This will serve to undermine system integration for health and social care if the capacity and capability for transformation is not attended to. Whilst there are ambitious global plans (WHO, 2015) to enable integrated services to be driven by citizen need, there is still a considerable void in understanding how to authentically engage with people to ensure transformation is driven by their needs as opposed to what we think they need. There is therefore a need for systems leaders with the full skillset required to enable integrated services across place-based systems, particularly clinicians who are able to break down barriers and silo working across boundaries through the credibility, leadership and facilitation expertise they provide. 


\section{Areas for Development}

967 Six key areas were identified in this study for development. The first is linked to the nature of 968 the leadership literature which is predominantly atheoretical in its understanding of the links 969 between contexts, mechanisms and outcomes. Hence the distillation of insights has been 970 based at a level of abstraction that informs the scope of the research landscape but is much 971 more tentative in generating theory. Recognising that theory is tentative, the level of 972 abstraction applied has been very broad. There is therefore more scope to research this 973 further and more specifically.

974

The second area, is that we have been heavily influenced by our philosophical predispositions captured in the substantive theories that have influenced the study and which have led us to focus on contexts and mechanism of leadership in health care contexts that are practical and common to any context. We have not been able to distil whether there are discriminating contexts and mechanisms that relate specifically to practice, education, research and 980 strategic/policy contexts. The focus on leadership in military contexts is an area recognised 981 as requiring further research, this arose from the Wales workshop.

982

983 The time limited nature of this inquiry into the strategies that work and why they work based 984 on realist evaluation has enabled the development of theories that have been refined to a 985 certain level. So whilst the key influential mechanisms have been distilled through working 986 with leaders working in different contexts across nursing, midwifery and allied health 987 professional practice through the workshops and social media, continued opportunities for 988 989

990 Fourth, the methods used have focused on perspectives from the literature and the 991 perceptions of nurses, midwives and allied health professions themselves across a wide range 992 of contexts, many of whom who have been recognised by peers as leaders in their own rights. 993 Other methods to refine the CMO relationships would therefore benefit further consideration, 994 995

996 Fifth, whilst developing philosophical understandings of leadership, other terms that focus on e.g. observational research and also longitudinal research.

1000 co-creation, social capital, self-organising communities etc. have been used in the literature and the search terms used may not have been inclusive enough to pick up innovations. This relates also to our focus in the search term - for pragmatic reasons- on nursing and consequentially, we may not have picked up on some of the innovative leadership happening within the allied health professionals and other healthcare contexts.

Lastly, the outcomes of leadership research mostly focused on staff outcomes and intermediate outcomes that are then linked to ultimate outcomes in both staff and patients (Supplemental). The relationship between staff outcomes and patient outcomes has previously been demonstrated (West et al; 2017), more consideration needs to be given to the impact of leadership on patients, carers and their families.

\section{Limitations}

1009 The study provides a detailed snapshot of the context, mechanisms and outcomes of NMAHP 1010 leadership that warrants further detailed exploration in a follow up study. We have not been 
1011 able to distil whether there are discriminating contexts and mechanisms that relate specifically 1012 to practice, education, research and strategic policy/contexts from the work undertaken to 1013 date. Continued opportunities for engagement with practitioners would have enabled further 1014 refinement of the mechanisms distilled. Other methods to refine the programme theories 1015 would benefit further consideration such as observational and longitudinal research. Further, 1016 our work is heavily influenced by our philosophical predispositions that have influenced the 1017 approach taken in this study.

\section{Conclusion}

1019 This realist evaluation has led to the development of a detailed landscape of factors distilled 1020 into relationships between context, mechanisms and outcomes that influence nursing, 1021 midwifery and applied health professional leadership in a range of different contexts. Three 1022 phases of collaborative work have included an interrogation of the literature, combined with 1023 appreciative framing and dialogue with workshop participants across the four countries of the 1024 UK, and an innovative social media strategy. Through a process of refinement and critique the 1025 initial programme theories 1) Authentic relationships and connections, 2) Transformational 1026 leadership linked to collective leadership and social capital and 3) Providing everyone a voice 1027 in complex and changing contexts. In the spirit of complex adaptive theory and the concept of 1028 'simple rules' these have been distilled into five guiding lights illuminated through a leadership 1029 as light metaphor. These capture the focus of effective leadership for contemporary nursing, 1030 midwifery and allied health practice in all contexts, and also guide a vision for strengthening 1031 what leadership needs to be in the future. They also provide an important practical resource 1032 for supporting the development of leadership talent and capability across the system to 1033 strengthen NMAHP career development and capacity building for the future. The work has 1034 highlighted the a-theoretical nature of leadership theory currently and will be the focus of a 1035 future paper by the authors in which we seek to challenge the leadership landscape and offer 1036 a contemporary critical review and argument for why theory is important for understanding and 1037 sustaining change at micro-meso and macro levels of the health and care system. 


\section{References}

1040 Adamson, E., Dewar, B., Donaldson, J. H., et al.(2011), 'Leadership in compassionate care 1041 programme: final report.', Edinburgh, Scotland: NHS Lothian/ Edinburgh Napier University. 1042 [Online] Available: https://www.napier.ac.uk/ /media/worktribe/output1043 192596/compcarefinreptallapr13pdf.pdf [Last accessed 14th January 2019].

1044 Akerjordet, K. and Severinsson, E. (2008), 'Emotionally intelligent nurse leadership: a 1045 literature review study', Journal of Nursing Management. Vol.16, pp.565-577.

1046 Akhtar, M., Casha, J.N., Ronder, J., et al. (2016), 'Leading the health service into the future: 1047 transforming the NHS through transforming ourselves', International Journal of Practice 1048 Development, Vol.6, No.2, [Online] Available: https://www.fons.org/library/journal/volume61049 issue2/article5 (Last accessed 14th January 2019).

1050 Bass B.M. \& Avolio B.J. (1994), 'Improving Organizational Effectiveness Through

1051 Transformational Leadership'. Sage, CA.

1052 Beirne M. (2017),'The reforming appeal of distributed leadership', British Journal of Health 1053 Care Management, Vol. 23 No. 6, pp. 262-70.

1054 Bell, C.A., and Colleran, V. (2018), 'Empowering Nurses, Midwives and Allied Health 1055 Professionals to Gain an Academic, Research and Quality Improvement Experience within 1056 Clinical Practice," International Journal of Practice-Based Learning in Health and Social 1057 Care, Vol. 7, No.2, pp. 69-79. https://doi.org/10.18552/ijpblhsc.v7i2.641

1058 Best, A., Greenhalgh, T., Lewis, S., et al. (2012), 'Large-System Transformation in Healthcare: 1059 A Realist Review', The Milbank Quarterly, Vol.90. No. 3, pp. 421- 456. DOI: 10.1111/j.1468$1060 \quad 0009.2012 .00670 . x$

1061 Bøgh Andersen, L., Bjørnholt, B., Ladegaard Bro, L., and Holm-Petersen, C. (2018). 1062 'Achieving High Quality Through Transformational Leadership: A Qualitative Multilevel 1063 Analysis of Transformational Leadership and Perceived Professional Quality'. Public 1064 Personnel Management, Vol.47, No.1, pp. 51-72.

1065 Boamah SA, Spence Laschinger HK, Wong C, Clarke S. (2018). 'Effect of transformational 1066 leadership on job satisfaction and patient safety outcomes'. Nursing Outlook Mar-Apr Vol 66, 1067 No.22, pp.180-189. doi: 10.1016/j.outlook.2017.10.004. Epub 2017 Nov 23. PMID: 29174629.

1068 Brown, B. (2017), 'Braving the Wilderness. The Quest for True Belonging and the Courage 1069 to Stand Alone'. Random House: New York.

1070 Bushe, G. and Kassam, A. (2005), 'When is appreciative inquiry transformational? A meta1071 case analysis'. The Journal of Applied Behavioral Science, Vol. 41 No. 2, pp. 161-181. 1072 https://doi. org/10.1177/0021886304270337.

1073 Bushe, G. and Marshak, R. (2016). 'The dialogic mindset: leading emergent change in a 1074 complex world.' Organization Development Journal, Vol. 34, No. 1, pp 37-65.

Cardiff, S., Sanders, K., Webster, J., Manley, K., (2020), 'Guiding lights for effective workplace cultures that are also good places to work.' International Practice Development Journal, Vol 10, Issue 2, Article 2. https://doi.org/10.19043/ipdj.102.002. 
1080 Coad J., Manning J.C., Mills E., Semple C., et al., (2019), 'Capturing the Real Impact of 1081 Clinical Academics in Practice'. International Journal of Practice-Based Learning in Health 1082 1083 1084 1085 1086 1087

\section{8} 1089

1090 1091 1092 1093 1094 1095 1108 1109 1110 1111

1118 Dewar, B., and Cook, F. (2014), 'Developing compassion through a relationship centred 1119 leadership programme.' Nurse Education Today, Vol. 34 No. 9, pp.1958-64.

1120 Dewar, B., and MacBride, T. (2017), 'Developing Caring Conversations in care homes: an 1121 appreciative inquiry'. Health and Social Care in the Community 2 Vol.25 No.4, pp.1375-1386.

De Brún, A. and McAuliffe, E. (2020), 'Identifying the context, mechanisms and outcomes underlying collective leadership in teams: building a realist programme theory '. BMC Health Services Research, Vol 20, p:261 https://doi.org/10.1186/s12913-020-05129-1

De Brún, A., O’Donovan, R. \& McAuliffe, E.(2019), 'Interventions to develop collectivistic leadership in healthcare settings: a systematic review.' BMC Health Services Research Vol. 19, p. 72, https://doi.org/10.1186/s12913-019-3883-x

de Zulueta, P.C. (2016), 'Developing compassionate leadership in health care: an integrative review.' Journal of Healthcare Leadership, Vol.8, pp.1-10.

Dewar, B., Barrie, K., Sharp, C. and Meyer, J., (2017a), Implementation of a Complex Intervention to Support Leadership Development in Nursing Homes: A Multimethod Participatory Study. Journal of Applied Gerontology, Vol. 38 No. 7, pp/ 931-958. DOI: 10.1177/0733464817705957

1122

Cohn S., Clinch M., Bunn C., Stronge P. (2013), 'Entangled complexity: why complex interventions are just not complicated enough.' Journal of Health Services Research Policy.

Cooperrider, D., Whitney, D., Stavros, J. (2008), 'Appreciative Inquiry Handbook.' Ohio:

Cummings, G., MacGregor, T., Davey, M., et al., (2010), 'Leadership styles and outcome patterns for the nursing workforce and work environment: a systematic review' International Dalkin S.M, Greenhalgh J., Jones D., et al., (2015), 'What's in a mechanism? Development of a key concept in realist evaluation. Implementation

Davidoff, F., Dixon-Woods, M., Leviton, L., et al. (2015)., Demystifying theory and its use in Davies, N. (2013), 'Visible leadership: going back to the front line.' Nursing Management UK. Vol.20 No.4, pp. 22-26.

De Brun A., Rogers L., O'Shea M., McAuliffe E.(2020), 'Understanding the impact of a collective leadership intervention on team working and safety culture in healthcare teams: a realist evaluation protocol.' HRB Open Research. Mar Vol. 26 No. 2, p. 5. doi: 10.12688/hrbopenres.12860.2. 
1123 Dewar, B., Sharp, C., Barrie, K., MacBride, T., and Meyer, J. (2017b), 'Caring conversation 1124 framework to promote person centred care: synthesising qualitative findings from a multiphase 1125 programme of research'. International Journal of Person-Centred Medicine, Vol.7 No. 1, 1126 pp.21-35.

1127 Dewar, B. (2012). 'Using creative methods in practice development to understand and 1128 develop compassionate care'. International Practice Development Journal. Vol 2. No. 1. 1129 Article 2. pp 1-11. Retrieved from: fons.org/library/journal/volume2-issue1/article2. (Last accessed $16^{\text {th }}$ September 2020).

1131

1132

Duignan, M., Drennan, J., McCarthy, V.J.C. (2020), 'Impact of clinical leadership in 1133 advanced practice roles on outcomes in health care: A scoping review' Journal of Nursing 1134 Management pp. 1- 10. https://doi.org/10.1111/jonm.13189

1135

Edmonson, A.C., and Lei, Z. (2014), 'Psychological Safety: The History, Renaissance, and 1136 Future of an Interpersonal Construct.' Annual Review of Organizational Psychology and 1137 Organizational Behaviour. Vol.1, pp.23-43.

1138 Edmonstone, J. (2011), 'Developing leaders and leadership in health care: a case for 1139 rebalancing?' Leadership in Health Services, Vol. 24 No. 1, pp: 8-18.

1140 Emmel N., Greenhalgh J., Manzano A., et al., (2018), 'Doing realist research'. London: SAGE.

1141

1142

1143

1144

1145

1146

1147

1148

1149

1150

1151

1152

1153

1154

1155

1156

1157

1158

1159

1160 1161

Endres, S., Weibler, J. (2020), 'Understanding (non)leadership phenomena in collaborative interorganizational networks and advancing shared leadership theory: an interpretive grounded theory study.' Business Research, Vol 13, pp. 275-309. https://doi.org/10.1007/s40685-019-0086-6

Franks-Meeks, S. (2018), 'Clinical staff nurse leadership: Identifying gaps in competency development'. Nursing Forum, Vol.53, pp.35-39.

Fynes, E., Martin, D., Hoy, L., and Cousley, A. (2014), 'Anaesthetic nurse specialist role: leading and facilitation in clinical practice,' Journal of Perioperative Practice, Vol.24 No. 5, pp. 97-102.

Gergen, K.J. (1982). 'Towards transformation of social knowledge'. Spring Valley: New York Gifford, W.A., Squires, J.E., Angus, D.E. et al. (2018).'Managerial leadership for research use in nursing and allied health care professions: a systematic review'. Implementation Science, Vol 13, p. 127. https://doi.org/10.1186/s13012-018-0817-7

Gilmore B, McAuliffe E, Power J, Vallières F.(2019), 'Data analysis and synthesis within a realist evaluation: toward more transparent methodological approaches.' International Journal of Qualitative Methods, 18:1609406919859754

Gopee, N., \& Galloway, J. (2017). 'Leadership and Management in Health Care. $3^{\text {rd }}$ edition. London: Sage. 
1162 Gottlieb, K. (2013), 'The Nuka System of Care: improving health through ownership and 1163 relationships.' International Journal of Circumpolar Health,Vol 72. [Online] Available: 1164 https://www.ncbi.nlm.nih.gov/pmc/articles/PMC3752290/ [Accessed 11 th March 2019].

1165

1166

1167

1168

1169

1170

1171

1172

1173

1174

1175

1176

1177

1178

1179

1180

1181

1182

1183

1184

1185

1186

1187

1188

1189

1190

1191

1192

1193

1194

1195

1196

1197

1198

1199

1200

1201

1202

1203

1204

1205

1206
Greenhalgh, T., \& Papoutsi, C. (2018), 'Studying complexity in health services research: desperately seeking an overdue paradigm shift'. BMC Medicine, Vol 16 No.1, p. 95. https://doi.org/10.1186/s12916-018-1089-4

Guba, E. G., \& Lincoln, Y. S. (1994), 'Competing paradigms in qualitative research'. In N. K. Denzin \& Y. S. Lincoln (Eds.), Handbook of qualitative research (pp. 105-117). Sage

Publications, Inc.

Hannah, M. (2016), 'Humanising health care, Independent Nurse.' [Online] Available: http://www.independentnurse.co.uk/professional-article/humanising-healthcare/141730.

[Accessed 14th January 2019].

Hewison, A., and Morrell, K. (2014), 'Leadership development in the English National Health Service: A counter narrative to inform policy'. International Journal of Nursing Studies, Vol.51 No. 4, pp.677-688.

Hocking L, Newbould,J. Parkinson, S. et al , (2020), 'An evaluation of the Q Initiative 20162020'. RAND Europe. https://www.rand.org/randeurope/research/projects/evaluating-qinitiative-2016-2020.html. (accessed 3.12.2020).

Hollnagel E., Wears R.L. and Braithwaite J. (2015), 'From Safety-I to Safety-II: A White Paper'. The Resilient Health Care Net: Published simultaneously by the University of Southern Denmark, University of Florida, USA, and Macquarie University, Australia.

Hurlock-Chorostecki, C., and McCallum, J. (2016), 'Nurse Practitioner Role Value in Hospitals: New Strategies for Hospital Leaders'. Nursing, Vol.29 No. 3, pp: 82-92.

Hultin, L. and Mähring, M. (2017). 'How practice makes sense in healthcare operations: studying sensemaking as performative, material-discursive practice'. Human Relations, Vol. 70, No. 5. pp 566-593. https://doi.org/10.1177/0018726716661618.

Jackson, C., Manley, K.,Webster, J., Hardy, S. (in press),'System wide learning from first wave Covid 19: A realist synthesis of what works?". BMC Health Services Research.

King's Fund (2011) ,'The Future of Leadership and Management in the NHS: No More Heroes. London: The King's Fund.

Kouzes J.M. \& Posner B.Z. (1995) , 'The Leadership Challenge: How to Get Extraordinary Things Done in Organizations', 2nd edn. Jossey-Bass Publishing, San Francisco, CA.

Kuluski K, Guilcher SJT. (2019), 'Toward a Person-Centred Learning Health System: Understanding Value from the Perspectives of Patients and Caregivers'. Healthcare Papers, Dec, Vol. 18,No.4, pp.36-46. doi: 10.12927/hcpap.2019.26030. PMID: 31901067.

Kvist T, Mäntynen R, Turunen H, Partanen P, et al. (2013), ' How magnetic are Finnish hospitals measured by transformational leadership and empirical quality outcomes?' Journal of Nursing Management, Jan, Vol.21 No. 1, pp. 152-64. doi: 10.1111/j.1365-

2834.2012.01456.x. 
Manley, K. (2014), 'Professional credibility: A Framework for executive nurse effectiveness. Final Report.' ECPD ISBN 9781909067233

1210

Manley, K., \& Jackson, C.(2020), 'The Venus model for integrating practitioner-led workforce transformation and complex change across the health care system' . Journal of Clinical Evaluation, Vol. 26 No. 2, pp. 622-634.

Manley. K., Jackson. C., McKenzie C., (2019), ' Microsystems culture change- a refined theory for developing person centred, safe and effective workplaces based on strategies that embed a safety culture'. International Journal of Practice Development, Vol. 9 No.2, pp. 134-141.

Manley, K., Martin, A., Jackson, C., \& Wright, T. (2018), 'A realist synthesis of effective continuing professional development (CPD): A case study of healthcare practitioners' CPD'. Nurse Education Today, Vol. 69, pp. 134-141.

Manley, K., Sanders, K., Cardiff, S., Webster, J. (2011a), 'Effective Workplace Culture: The Attributes, Enabling Factors and Consequences of a New Concept'. International Practice Development Journal Vol 1 No2 Article 1. https://www.fons.org/Resources/Documents/Journal/Vol1No2/IPDJ_0102_01.pdf

Manley, K., Webster, J., Hale, N., Hayes, N. et al. (2008), 'Leadership role of Consultant Nurses working with older people: a co-operative inquiry.' Journal of Nursing Management. Vol.16, pp.147-158.

Mannion, R., Davies, H.T.O. and Marshall, M.N. (2005), "Cultural characteristics of "high" and "low" performing hospitals", Journal of Health Organization and Management, Vol. 19 No. 6, pp. 431-439, https://doi.org/10.1108/14777260510629689

Martin, A. \& Manley K. (2017), 'Developing standards for an integrated approach to workplace facilitation for interprofessional teams in health and social care contexts: a Delphi study', Journal of Interprofessional Care, Jan, Vol. 32 No. 1, pp. 41-51.

https://www.tandfonline.com/doi/abs/10.1080/13561820.2017.1373080?journalCode=ijic20

\section{Maitlis, S. and Christianson, M. (2014). 'Sensemaking in organizations: taking stock and moving forward.' Academy of Management Annal, Vol. 8, No. 1. pp 57-125. https://doi.org/10.5465/19416520.20 14.873177.}

McAuliffe E, De Brún A, Ward M, et al. (2017), 'Collective leadership and safety cultures (CoLead): protocol for a mixed-methods pilot evaluation of the impact of a co-designed collective leadership intervention on team performance and safety culture in a hospital group in Ireland.' BMJ Open, Vol 7:e017569. doi: 10.1136/bmjopen-2017-017569

Miller C, Cook J, Gibson J et al. (2020), 'Clinical academic research internships for nurses, midwives and allied health professionals: a qualitative evaluation', Nurse Researcher. doi: 10.7748/nr.2020.e1724

Morley G. (2018), 'What is "moral distress" in nursing? How, can and should we respond to it?.'Journal of Clinical Nursing, Vol 27 No. 19-20,pp. 3443-3445. https://doi.org/10.1111/jocn.14332 
1257 Morley, G. , Ives, J. , Bradbury-Jones, C. , \& Irvine, F. (2017), 'What is 'moral distress'? A 1258 narrative synthesis of the literature'. Nursing Ethics. 10.1177/0969733017724354 [Online 1259 First].

1260

Mullen, J. and Kelloway, E. (2009). 'Safety leadership: a longitudinal study of the effects of transformational leadership on safety outcomes'. Journal of Occupational and Organizational Psychology, Vol.82, pp.253-272.

Nagel, C., \& Andenoro, A. (2012), 'Healing leadership: the serving leader's impact on patient outcomes in a clinical environment.' Journal of Healthcare Leadership, Vol. 4. 1266 10.2147/JHL.S30046.

1267 National Improvement and Leadership Development Board. (2017), 'Developing People 1268 Improving Care: a national framework for action on improvement and leadership 1269 development in NHS-funded services'. [Online] Available: https://improvement.nhs.uk/uploads/documents/Developing_People-Improving_Care010216.pdf (Accessed 14th January 2019).

NHS England (2015), 'How to understand and measure impact'. Available at: https://www.england.nhs.uk/wp-content/uploads/2015/06/bcf-user-guide-04.pdf.pdf. (Accessed 14 $4^{\text {th }}$ January 2019)

NHS Improvement (2018), 'Creating a Culture of Compassionate and Inclusive Leadership'. 1276 [Online] Available: https://improvement.nhs.uk/resources/culture-leadership/ (Accessed 14th 1277 January 2019).

Nolan, M., Brown, J., Davies, S., et al. (2006), 'The senses framework: improving care for 1280 older people through a relationship centred approach'. Getting Research into Practice (GRiP) Report No 2. Study Report. Sheffield: University of Sheffield.

Parker D., Holesgrove M., Pathak R. D. (2015), 'Improving productivity with self organised teams and agile leadership', International Journal of Productivity and Performance Management, Vol. 64, pp. 112-128.

1285 Pawson, R. (2006), 'Evidence Based Policy. A Realist Perspective’. London: Sage.

Pawson, R., Greenhalgh, T., Harvey, G., Walshe, K. (2005), ' Realist Review-A New Method of Systematic Review Designed for Complex Policy Interventions.' Journal of Health Services Research and Policy, Vol.10 S1, pp.21-34.

1289 Pawson, R. \& Tilley, N. (2004), 'Realist Evaluation in Community Matters: Practical support 1290 for community services '[online] http://www.communitymatters.com.au/RE_chapter.pdf

1291 Peus, C., Wesche, J.S., Streicher, B., et al. (2012), 'Authentic leadership: an empirical test of 1292 its antecedents, consequences, and mediating mechanisms'. Journal of Business Ethics, 1293 Vol.107, pp.331-348.

Plsek, P. (2001), 'Redesigning Health Care with Insights from the Science of Complex Adaptive Systems.' In: Committee on Quality of Health Care in America, Institute of Medicine. Crossing the Quality Chasm: A New Health System for the 21st Century.[Online] pp.309-322. 1297 Available: https://www.ncbi.nlm.nih.gov/books/NBK222274/pdf/Bookshelf_NBK222274.pdf 1298 [Accessed 11th March 2019]. 
1299 Plsek, P. E., and Wilson, T. (2001), 'Complexity, leadership and management in healthcare 1300 organisations'. British Medical Journal, Vol. 323 No.7315, pp.746-749.

1301 Prezerakos P. E. (2018). 'Nurse Managers' Emotional Intelligence and Effective Leadership: 1302 A Review of the Current Evidence'. The Open Nursing Journal, Vol 12, pp. 86-92.

1303 https://doi.org/10.2174/1874434601812010086

1304 RAMESES II. Retroduction in realist evaluation: RAMESES II Project (2018), Available from: 1305 http://www.ramesesproject.org/Standards_and_Training_materials.php.

1306 Rycroft-Malone, J., McCormack, B., Hutchinson, A.M., et al. (2012). 'Realist synthesis: 1307 Illustrating the method for implementation research'. Implementation Science, Vol.7 No. 33, 1308 pp.1-10.

1309 Sharp, C. (2018), 'Collective leadership: Where nothing is clear and everything keeps 1310 changing.' Exploring new Territories for Evaluation, Workforce Scotland. [Online] Available: 1311 http://tinyurl.com/y6vll2hp [Accessed 11th March 2019].

1312 Sharp, C., Barrie, K., and Dewar, B. (2017), 'Forming new futures through appreciative 1313 inquiry'. [Online] Available: https://www.iriss.org.uk/resources/insights/forming-new-futures1314 through-appreciative-inquiry [Accessed 14th January 2019].

1315 Sharp, C., Dewar, B., Cook, F., Fulham, C., Arnott, T. and Brown, L (2017). 'A framework to 1316 learn from stories'. Retrieved from: tinyurl.com/Sharp-framework. (Last accessed 23rd June 1317 2020).

1318 Smith, M.J., and Liehr, P.R. (2008), 'Middle Range Theory for Nursing'. $2^{\text {nd }}$ edition. New York: 1319 Springer.

1320 Solkaridis, S., Ravits, P., Nevo, G.A., Lieff, S. (2016), 'Relationship Centred Care in Health: 1321 A 20 year Scoping Review.' Patient Experience Journal, Vol.3 No.1, pp.130-145.

1322 Soo Young, J. (2017), 'Mediating Effect of Social Capital between Transformational 1323 Leadership Behavior and Organizational Citizenship Behaviour in Hospital Nurses'. Journal of 1324 Korean Academy of Nursing Administration, Vol.23 No.5, pp.558-566.

1325 Stodd, J. (2016),'The Social Leadership Handbook'. (2nd edition). California: Smashwords.

1326 Tomlinson, J, (2012). 'Exploration of transformational and Distributed Leadership'. Nursing 1327 Management, Vol. 19, No. 4, pp.30-34.

Tresolini, C.P. and the Pew-Fetzer Taskforce (1994),'Health Professions Education and 1330 Relationship Centred Care. Report of the Pew-Fetzer Taskforce on advancing Psychosocial 1331 Health Education. '[Online] Available: https://healthforce.ucsf.edu/publications/health1332 professions-education-and-relationship-centered-care [Accessed 19th December 2018].

1333 University of Manchester (2017), 'Evaluation of the NHS Leadership Academy Intersect 1334 systems leadership programme - Part 2.' NHS Leadership Academy. (accessed 14.11.2020) 
1335 Wang, G., Oh, I., Courtright, S.H., Colbert, A.E. (2011). 'Transformational leadership and 1336 performance across criteria and levels: a meta-analytic review of 25 years of research.' Group 1337 \& Organization Management, Vol.36, No.2, pp. 223-270.

Watkins S., Dewar B., and Kennedy C. (2016), 'Appreciative Inquiry as an intervention to change nursing practice in in-patient settings: An integrative review.' International Journal of Nursing Studies, Vol. 60, pp. 179-190.

1342

1343

West, M., Armit, L., Eckert, R., et al. (2015), 'Leadership and Leadership Development in Health Care: The Evidence Base.' [Online] Available: tinyurl.com/KF-west- evidence 1345 1346 [Accessed $14^{\text {th }}$ January 2019].

West, M., Steward, K., Eckert, R. and Pasmore, B. (2014), 'Developing Collective Leadership for Healthcare'. [Online] Available: tinyurl.com/KF-west [Accessed 14th January 2019].

1349

1350

1351

1352

1353

World Health Organisation (WHO) (2015). 'WHO global strategy on people-centred and integrated health services'. Interim report. Geneva, Switzerland: World Health Organization. http://apps.who.int/iris/bitstream/10665/155002/1/WHO_HIS_SDS_2015.6_eng.pdf (accessed 20 January 2020).

Wong, C.A., Laschinger, H.K.S., and Cummings, G.G. (2010), 'Authentic leadership and nurses' voice behaviour and perceptions of care quality'. Journal of Nursing Management, 1356 Vol.18, No.8, pp.889-900.

Wong CA, Cummings GG, Ducharme L. (2013)., 'The relationship between nursing leadership and patient outcomes: a systematic review update.' Journal of Nursing Management., Jul, Vol. 1359 21 No 5, pp.709-24. doi: 10.1111/jonm.12116.

1360 Wong, G., Wethorp, G., Pawson, R., Greenhalgh, T. (2013), 'Realist Synthesis. Rameses 1361 Training.' [Online] Available:

1362 http://ramesesproject.org/media/Realist_reviews_training_materials.pdf [Accessed 8th 1363 March 2019].

1364 Wong G, Westhorp G, Manzano A, et al. (2016), 'RAMESES II reporting standards for realist 1365 evaluations' BMC Medicine, Vol 14 No.1, pp. 96. 19. 


\begin{tabular}{|c|c|c|c|c|c|c|c|c|c|}
\hline $1^{\text {No }}$ & & Reference & itegory & Setting & ntext & Mechanisms & Outcomes & Impact on whom & \\
\hline $\begin{array}{l}2 \\
3 \\
4 \\
5 \\
6 \\
7 \\
8 \\
9 \\
10 \\
11 \\
12 \\
13 \\
14 \\
15 \\
16\end{array}$ & 5 & 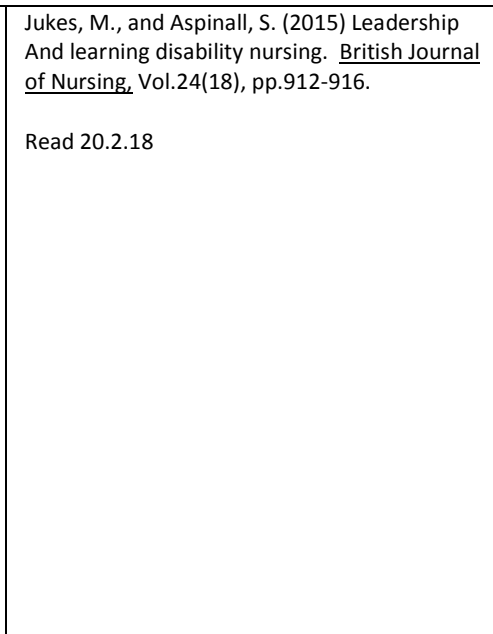 & \begin{tabular}{|l} 
Peer review journal \\
Discussion paper
\end{tabular} & $\begin{array}{l}\text { Learning disability nursing and } \\
\text { learning disability services. }\end{array}$ & 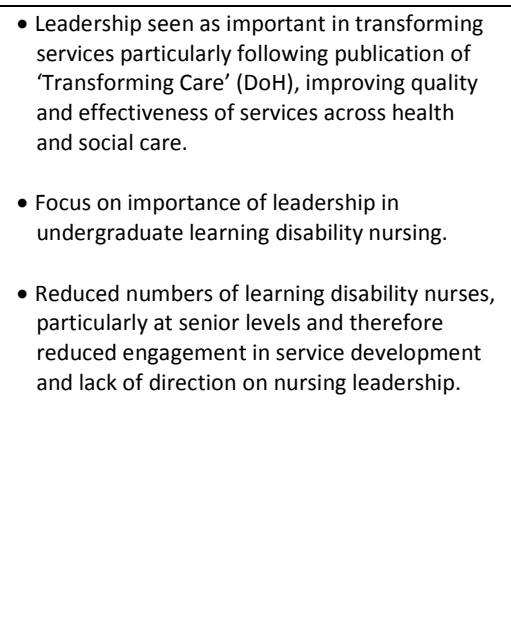 & 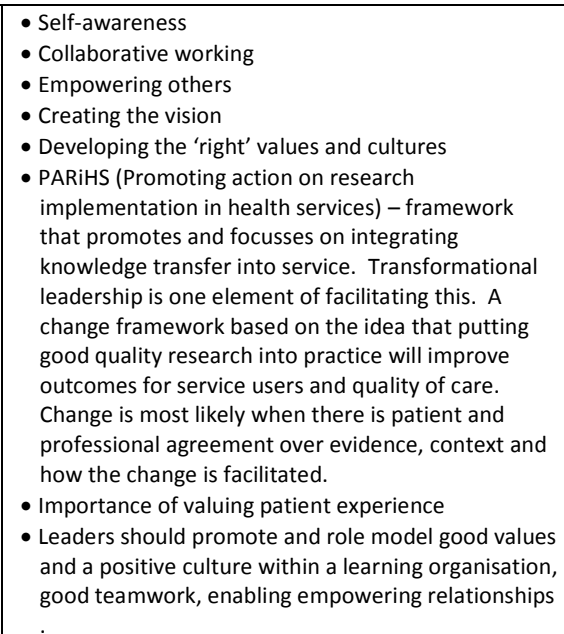 & $\begin{array}{l}\text {-Improved care/quality } \\
\text { - Change is more likely to happen }\end{array}$ & $\begin{array}{l}- \text { Service users (people with } \\
\text { learning disabilities) }\end{array}$ & \\
\hline $\begin{array}{l}18 \\
19 \\
20 \\
21 \\
22 \\
23 \\
24 \\
25 \\
26 \\
27 \\
28 \\
29 \\
29 \\
30 \\
31 \\
32 \\
33 \\
34\end{array}$ & 6 & 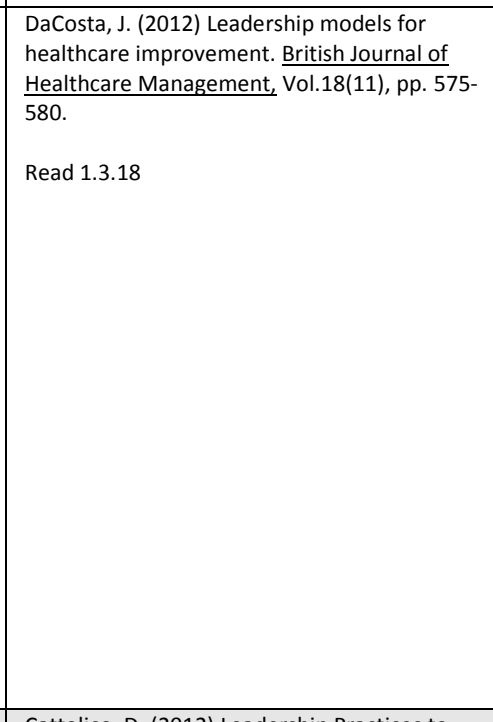 & \begin{tabular}{|l} 
Peer review journal \\
Review
\end{tabular} & 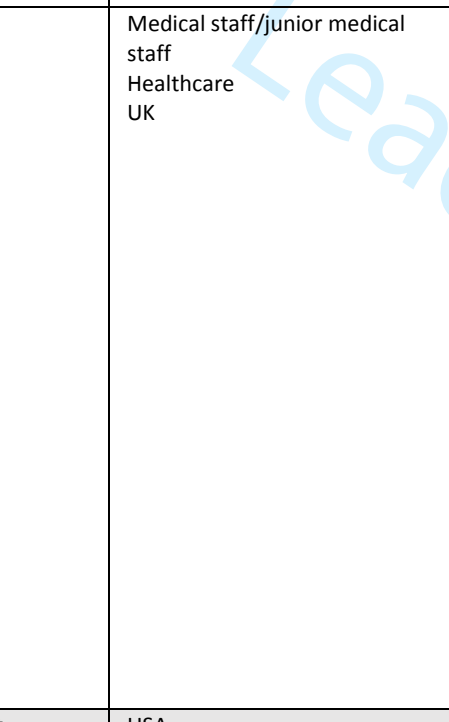 & 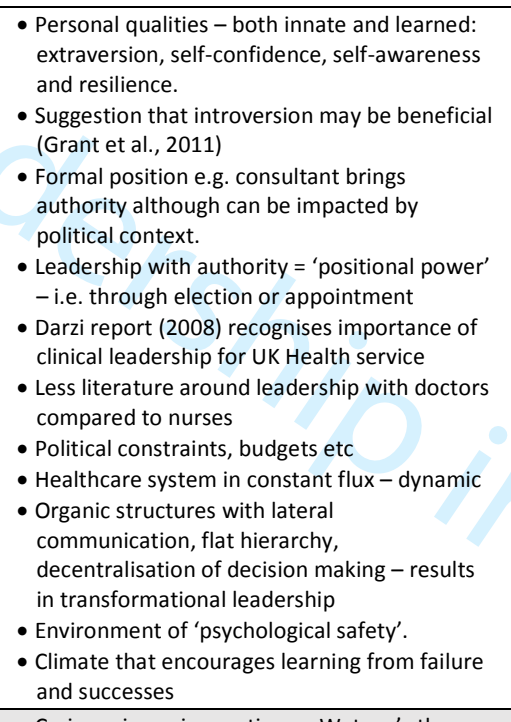 & 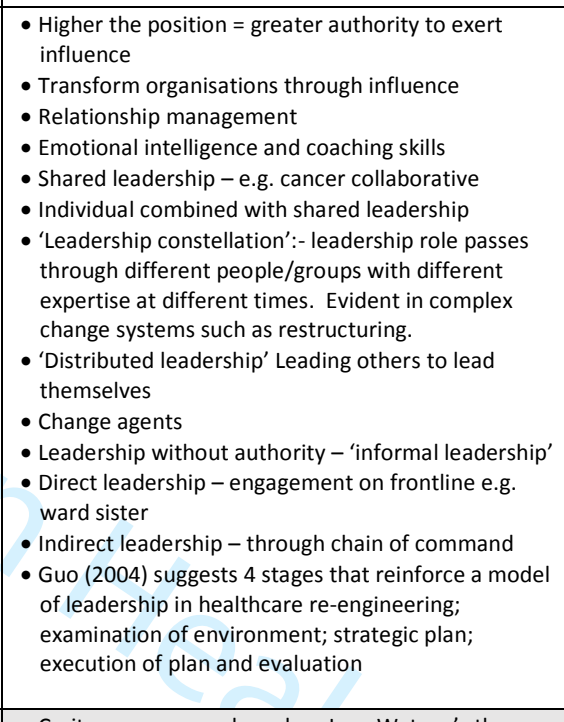 & 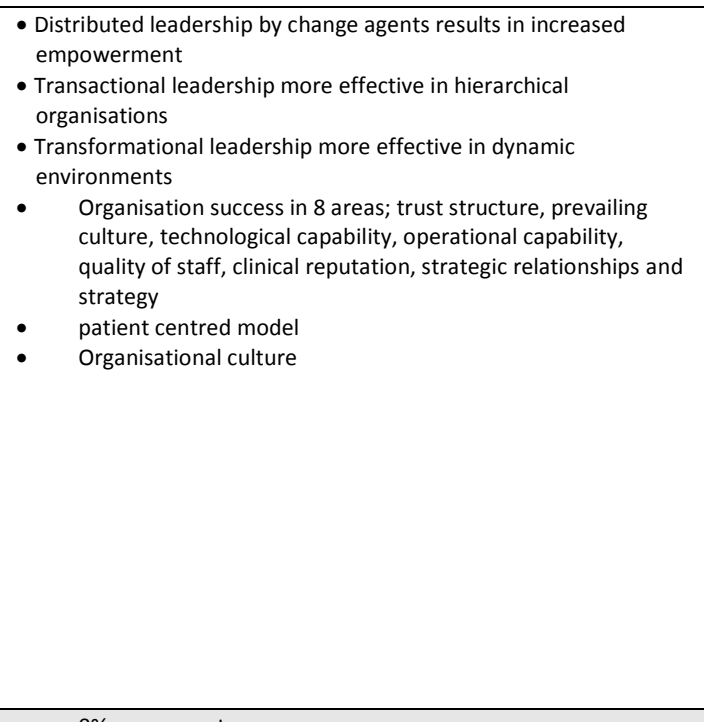 & $\begin{array}{l}- \text { Multi-Factor Leadership } \\
\text { Questionnaire (Avolio et al., 1990) } \\
\text { - Greater focus on nurses } \\
- \text { Increased transformational } \\
\text { leadership in particicative } \\
\text { organisations } \\
\text { - Organisation } \\
-\quad \text { Patients }\end{array}$ & $\begin{array}{l}\text { Paper also discusses } \\
\text { disadvantages of } \\
\text { transformational } \\
\text { leadership }\end{array}$ \\
\hline $\begin{array}{l}34 \\
35 \\
36 \\
37 \\
38 \\
39 \\
40 \\
41 \\
42\end{array}$ & 7 & 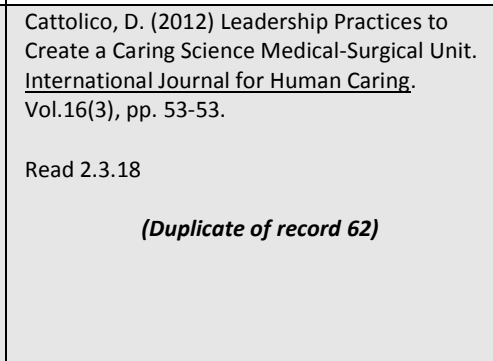 & \begin{tabular}{|l|l} 
Conference abstract \\
\end{tabular} & $\begin{array}{l}\text { USA } \\
\text { Acute nursing } \\
\text { 'Watso Caring science } \\
\text { Affiliate' }\end{array}$ & 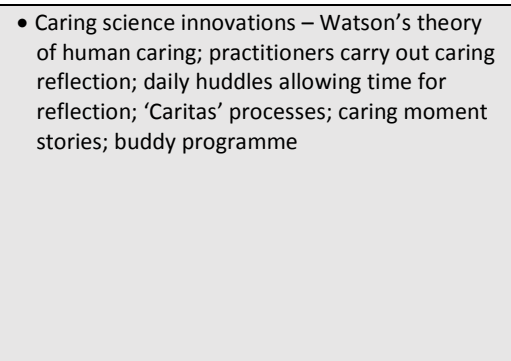 & 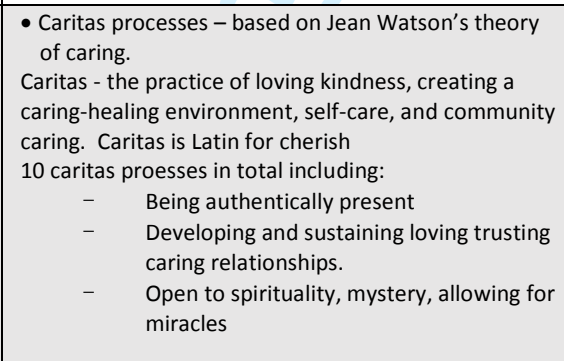 & $\begin{array}{ll}\text { : } & \text { \% vacancy rate } \\
\text { Informal comments that unit is 'changing' }\end{array}$ & & $\begin{array}{l}\text { This } \mathrm{CMO} \text { record is } \\
\text { duplicted } \\
\text { record } 62\end{array}$ \\
\hline $\begin{array}{l}43 \\
44 \\
45 \\
46 \\
47 \\
48 \\
49 \\
50 \\
51 \\
52 \\
53 \\
54 \\
55\end{array}$ & 8 & $\begin{array}{l}\text { Giltinane, C.L. (2013) Leadership styles and } \\
\text { theories, Nursing Standard. Vol.27(41), pp.35- } \\
\text { 39. } \\
\text { Read 2.3.18 }\end{array}$ & \begin{tabular}{|l} 
Peer review journal \\
Review paper
\end{tabular} & UK Heatthcare & 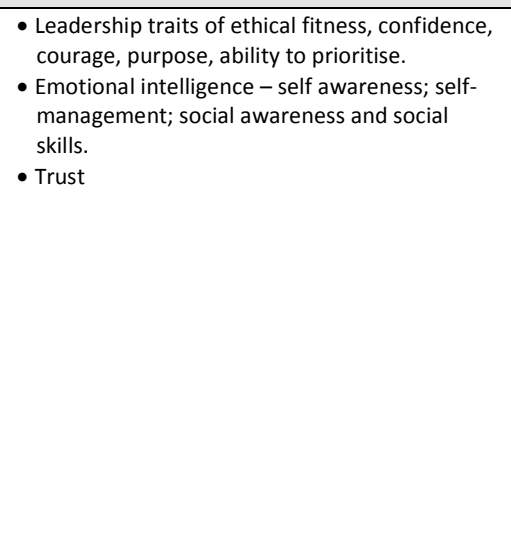 & 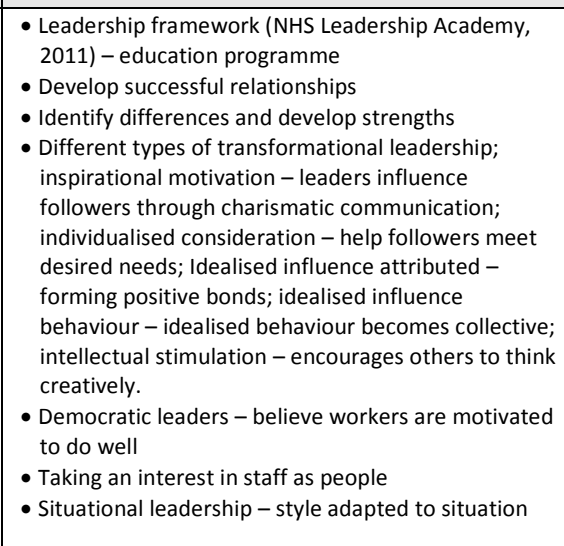 & $\begin{array}{l}\text { - Ability to influence others } \\
\text { - Empower others to become leaders } \\
\text { - Increased organisational loyalty, increased motivation and job } \\
\text { satisfaction, decreased sickness } \\
\text { - Positive work environment } \\
\text { - Feel valued, improved self-esteem }\end{array}$ & $\begin{array}{l}\text { - Improved patient outcomes } \\
\text { - Greater empowerment and clarity } \\
\text { over role for nurses }\end{array}$ & $\begin{array}{l}\text { Comparison of } \\
\text { transformatitional and } \\
\text { transactional } \\
\text { leadership as well as } \\
\text { situational and } \\
\text { democratic. }\end{array}$ \\
\hline $\begin{array}{l}56 \\
57 \\
58 \\
59 \\
60\end{array}$ & 9 & \begin{tabular}{|l} 
Norman, K. (2012) Leading service \\
improvement in changing times. \\
of Critish Journal \\
Community Nursing Vol.17(4), pp.162-167. \\
Read 2.3.18
\end{tabular} & \begin{tabular}{|l} 
Peer review journal \\
Discussion paper
\end{tabular} & $\begin{array}{l}\text { UK } \\
\text { Community nursing }\end{array}$ & 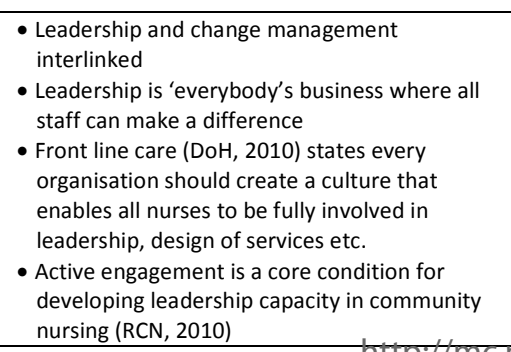 & 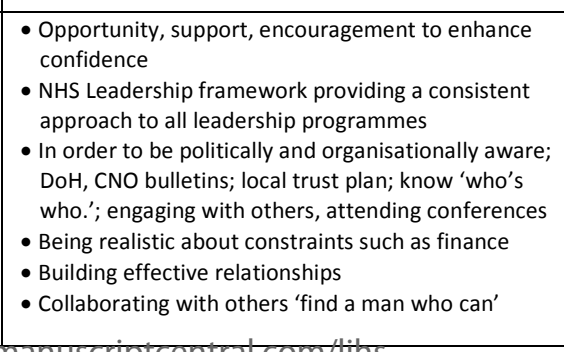 & - Improved delivery of services for patients, service users and carers & - Patients, service users, carers & $\begin{array}{l}\text { Discussion interlinks } \\
\text { change manageament } \\
\text { and leadership - focus } \\
\text { on PDSA cycle. }\end{array}$ \\
\hline
\end{tabular}




\begin{tabular}{|c|c|c|c|c|c|c|c|c|c|}
\hline & & Reference & itegory & & ntext & Mechanisms & Outcomes & Impact on whom & Notes \\
\hline $\begin{array}{l}3 \\
3 \\
4 \\
5 \\
6 \\
6 \\
7 \\
8 \\
9\end{array}$ & & & & & 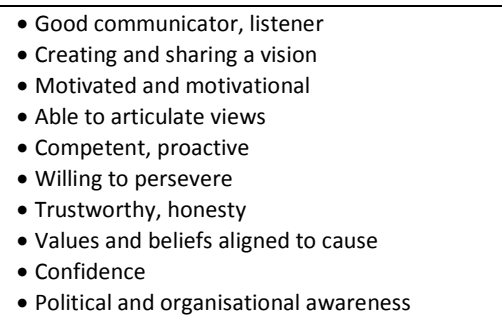 & \begin{tabular}{|l|}
$\begin{array}{l}\text {-Transformational leadership style with participative } \\
\text { methods }\end{array}$ \\
\end{tabular} & & & \\
\hline $\begin{array}{l}10 \\
11 \\
12 \\
13 \\
14 \\
15 \\
16 \\
17 \\
18\end{array}$ & 10 & $\begin{array}{l}\text { Grogan, L. (2011) Leading the way. World of } \\
\text { rirish Nursing \& Midwifery, Vol. 19(9), pp.38-39. } \\
\text { Read 2.3.18 }\end{array}$ & \begin{tabular}{|l|}
$\begin{array}{l}\text { Journal article } \\
\text { Pictorial }\end{array}$ \\
\end{tabular} & $\begin{array}{l}\text { Healthcare } \\
\text { Nursing and Midwifery } \\
\text { Ireland }\end{array}$ & $\begin{array}{l}\text { - Less staff and less available finance } \\
\text { - Increasingly complex organisations }\end{array}$ & $\begin{array}{l}\text { - Leadership at all levels } \\
\text { - Influencing and motivating others to achieve } \\
\text { mutually agreed goals } \\
\text { - Trust } \\
\text { - Supporting and guiding colleagues through } \\
\text { mentorship, supervision and inspiration } \\
\text { - National leadership and innovation centre for } \\
\text { Nursing and Midwifery - leadership programmes, } \\
\text { resources, } \\
\text { - entworks and partnership strategies, evaluation } \\
\text { tools }\end{array}$ & $\begin{array}{l}\text { High quality safe care } \\
\text { - Develop leadership competencies in nurses and midwives }\end{array}$ & $\begin{array}{l}- \text { Patients } \\
: \text { Nurses and midwives } \\
\text { O Organisation }\end{array}$ & \\
\hline $\begin{array}{l}19 \\
20 \\
21 \\
22 \\
23\end{array}$ & 11 & \begin{tabular}{|l} 
Goodare, P. (20177) Literature review: Why do \\
we continue to lose our urrses? Australian \\
Jounnal of Advanced Nursing, Vol. 34(4), pp. 50- \\
56. \\
Read 5.3.18 \\
Re
\end{tabular} & \begin{tabular}{|l|} 
Peer review journal \\
Research \\
Systematic review- \\
quantititative and qualitative
\end{tabular} & $\begin{array}{l}\text { Australia } \\
\text { Female dominated } \\
\text { Avergae age en1.6 vears } \\
\text { Increased acuity, workload } \\
\text { Ageing workforce }\end{array}$ & • Shortage of nurses & 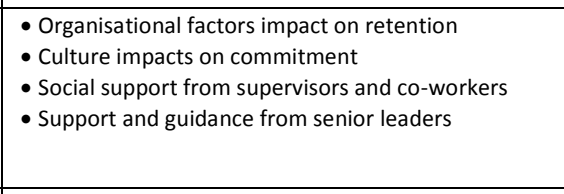 & - Retention of staff & & \\
\hline $\begin{array}{l}24 \\
25 \\
26 \\
27 \\
28 \\
29 \\
30 \\
31 \\
32 \\
33 \\
34 \\
35 \\
36 \\
37 \\
38 \\
39 \\
40 \\
41 \\
42 \\
43 \\
44 \\
45 \\
46 \\
47 \\
48 \\
49 \\
50\end{array}$ & 12 & $\begin{array}{l}\text { Zimring, C., Hyun-Bo, S. (2012) Making Acuity- } \\
\text { Adaptable Units Work Lessons From the field. } \\
\text { Health Envirnments Research \& Design } \\
\text { Journal Vol. } 5(3) \text {, pp.115-128. } \\
\text { Read 5.3.18 }\end{array}$ & \begin{tabular}{|l|} 
Peer review journal \\
Qualitative research
\end{tabular} & $\begin{array}{l}\text { Acuity adaptable units (AAUs) } \\
\text { USA } \\
\text { Nurses }\end{array}$ & 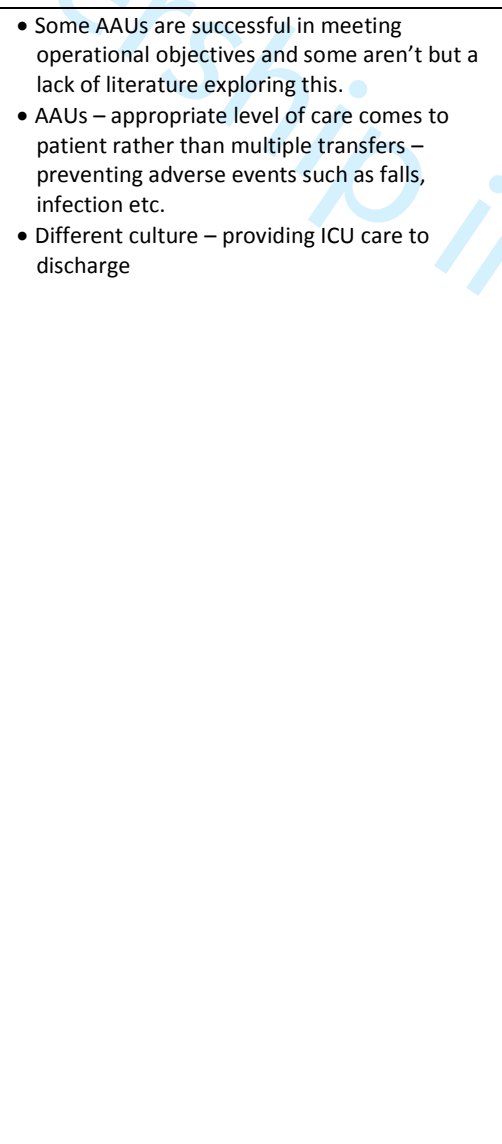 & 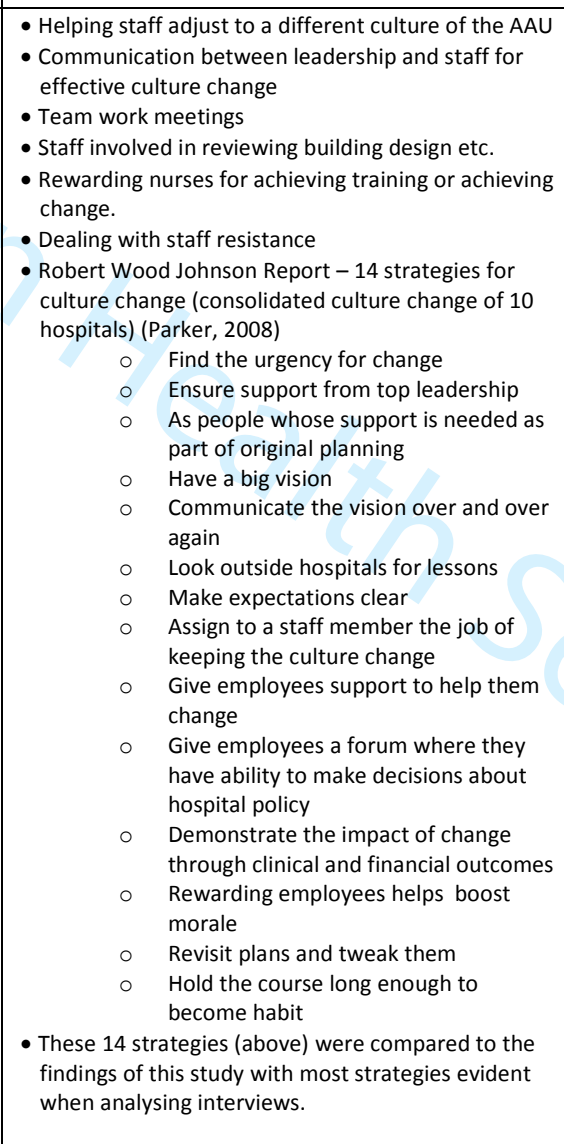 & $\begin{array}{l}\text { - Patient satisfaction - continuity with staff } \\
\text { - Reduced adverse events }\end{array}$ & $\begin{array}{l}\text { - Patients } \\
\text { - Organisation }\end{array}$ & \\
\hline $\begin{array}{l}51 \\
52 \\
53 \\
54 \\
55 \\
56 \\
57 \\
58 \\
59 \\
60\end{array}$ & 13 & 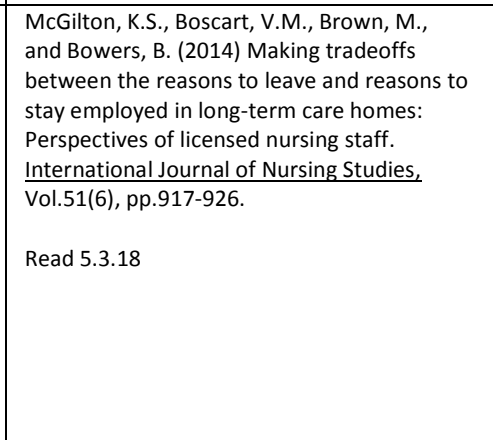 & \begin{tabular}{|l|} 
Peer review journal \\
Mixed methods \\
Quantitative and focus \\
groups
\end{tabular} & $\begin{array}{l}\text { Canada } \\
\text { Long term care } \\
\text { Nurses }\end{array}$ & 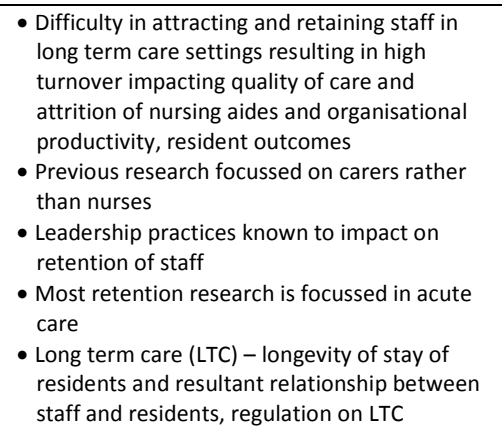 & 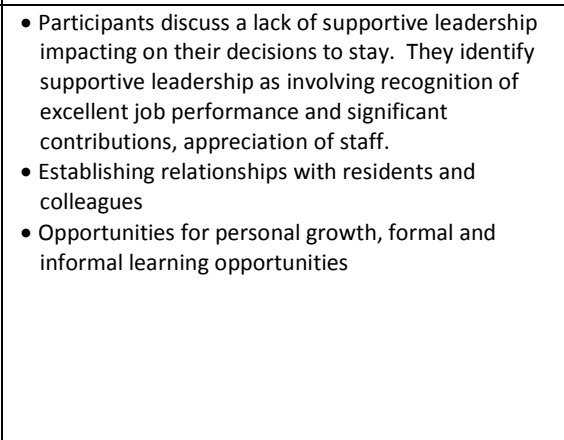 & $\begin{array}{l}\text { - Staff retention } \\
\text { - Enhanced resident outcomes }\end{array}$ & $\begin{array}{l}\text { Residents } \\
\text { - Staff } \\
\text { - Organisation }\end{array}$ & \\
\hline & 14 & \begin{tabular}{|l} 
Shearer, D.A. (2012) Management styles and \\
motivation. Radiology Management, Vol. 34(5), \\
pp. .77-52.
\end{tabular} & \begin{tabular}{|l|} 
Peer review journal \\
Literature review
\end{tabular} & Healthcare & $\begin{array}{l}- \text { Combinations of transformational and } \\
\text { - transactional leadership } \\
\qquad \mathrm{http}: / / \mathrm{mc} \text {. }\end{array}$ & 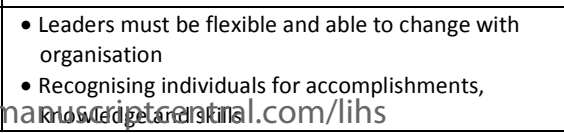 & $\begin{array}{l}\text { - Staff motivation } \\
\text { Staff satisfaction - by combination of transactional contingent } \\
\text { - eward system and transformational leadership behaviours. } \\
\text { Followers findinn own nath to a autonomy }\end{array}$ & $\begin{array}{l}\cdot \text { Staff } \\
\cdot \text { Service quality }\end{array}$ & \\
\hline
\end{tabular}




\begin{tabular}{|c|c|c|c|c|c|c|c|c|c|}
\hline 1 No & & Reference & tegory & & ntext & Mechanisms & Outcomes & Impact on whom & Notes \\
\hline $\begin{array}{l}3 \\
3 \\
4 \\
5 \\
6 \\
7 \\
8 \\
9 \\
10\end{array}$ & & \begin{tabular}{|l|l|} 
Read 5.3.18 \\
\end{tabular} & & & & 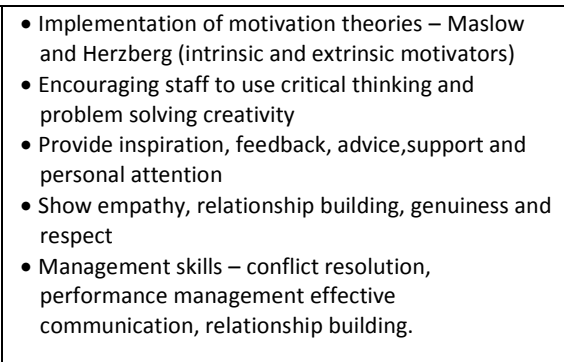 & & & \\
\hline $\begin{array}{l}11 \\
12 \\
13 \\
14 \\
15 \\
16 \\
17 \\
18 \\
19 \\
20 \\
21 \\
22 \\
23 \\
24 \\
25 \\
26 \\
27\end{array}$ & 15 & 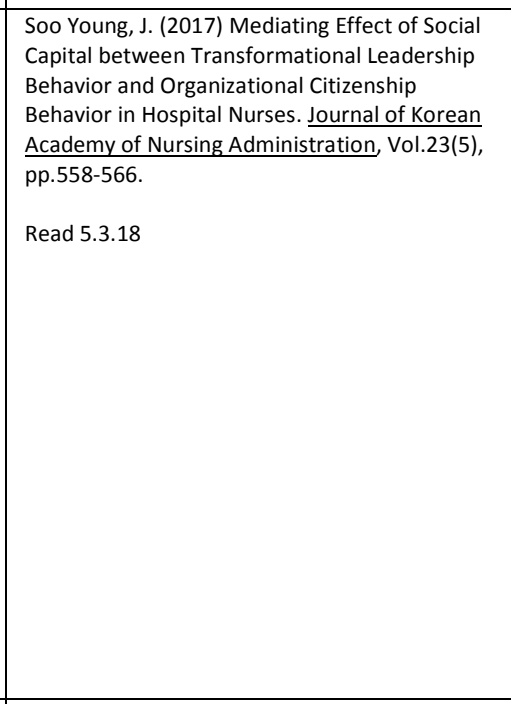 & \begin{tabular}{|l|} 
Peer review journal \\
Cross-sectional descriptive \\
studyd exploring relationship \\
between transformational \\
leadership behaviours, social \\
capita and organisation \\
citizenship behaviour
\end{tabular} & $\begin{array}{l}\text { South Korea } \\
2 \text { 2hospitals } \\
\text { Nurses }\end{array}$ & 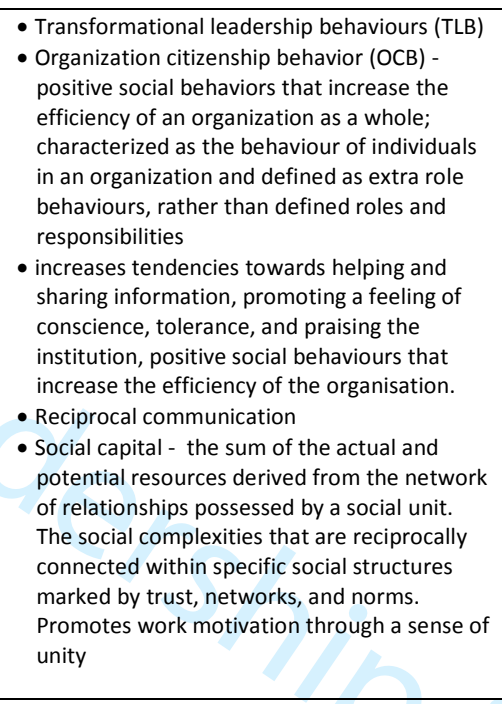 & $\begin{array}{l}\text { - Enhance OCB and determine OCB levels } \\
\text { - Infrasctructure that helps members actively interact } \\
\text { - Organisational training programmes } \\
\text { - Support nurses to have confidence in their practice } \\
\text { - Shared vision }\end{array}$ & 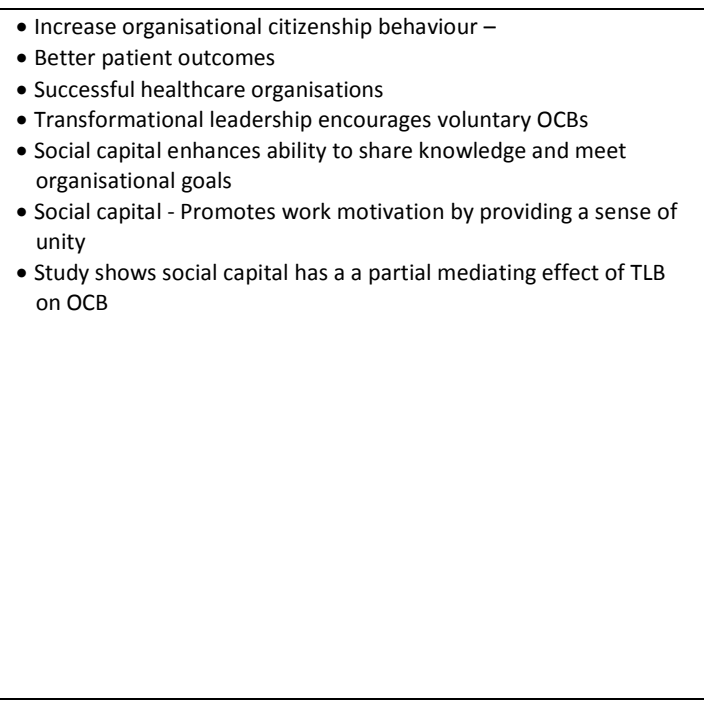 & $\begin{array}{l}\text { - Patients } \\
\text { - Organisations }\end{array}$ & 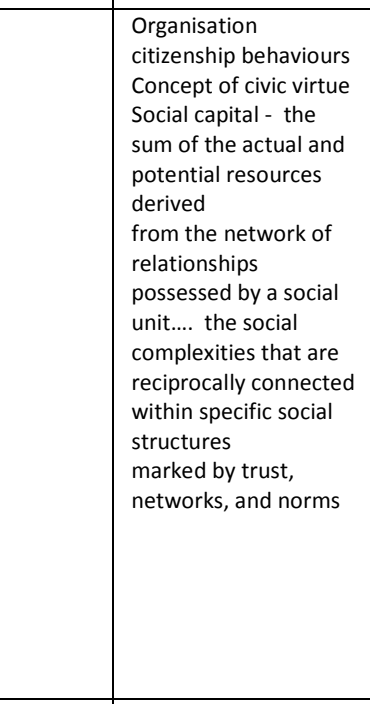 \\
\hline $\begin{array}{l}28 \\
29 \\
29 \\
30 \\
31 \\
32 \\
33 \\
34 \\
35 \\
36 \\
36 \\
37 \\
38 \\
39 \\
40 \\
40 \\
41 \\
42 \\
43 \\
44 \\
45 \\
46 \\
47\end{array}$ & 16 & 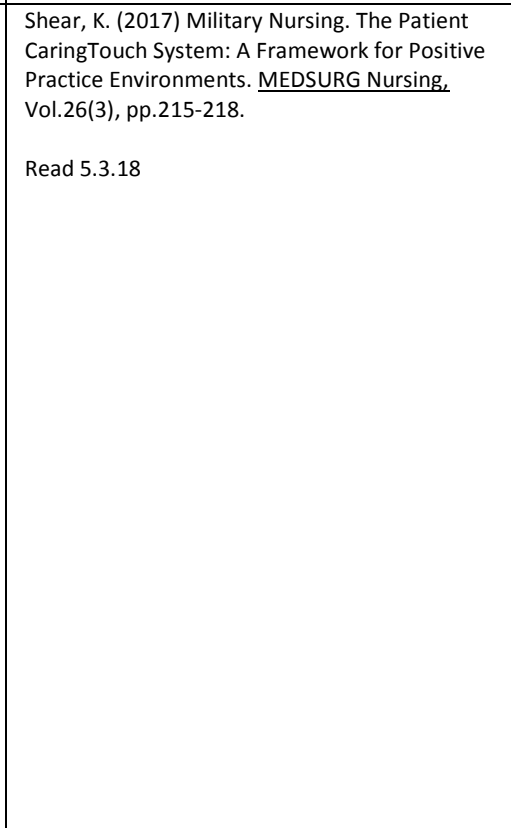 & \begin{tabular}{|l|} 
Peer review journal \\
Discussion paper
\end{tabular} & 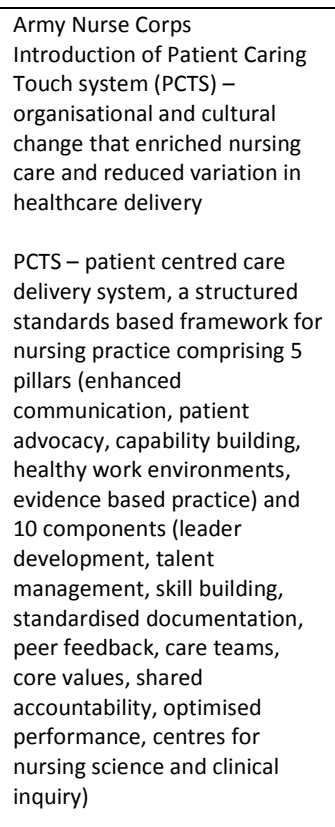 & 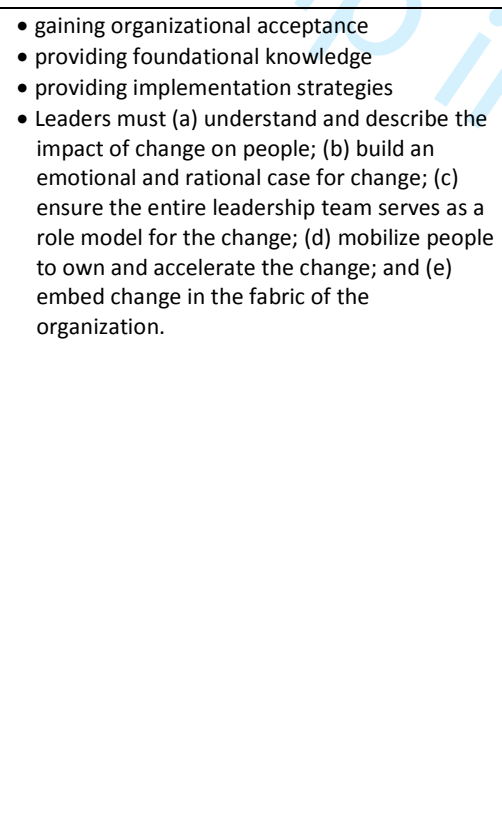 & 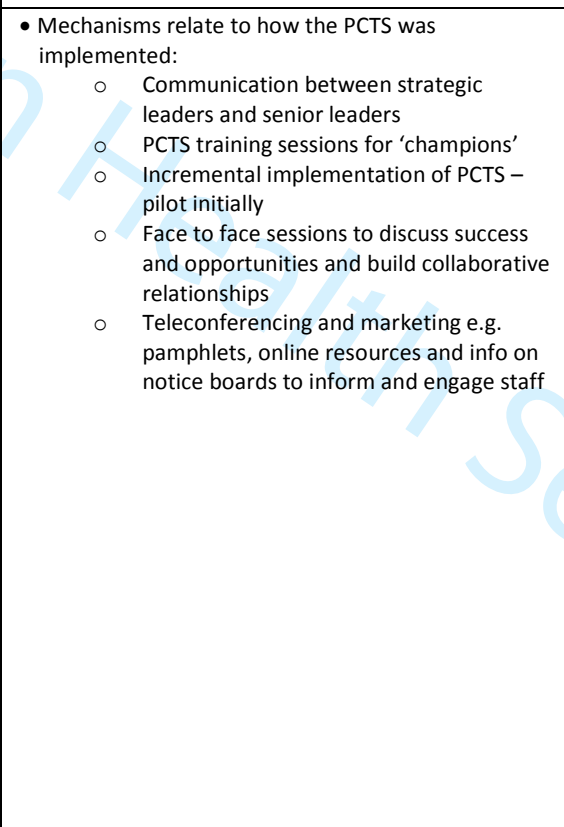 & 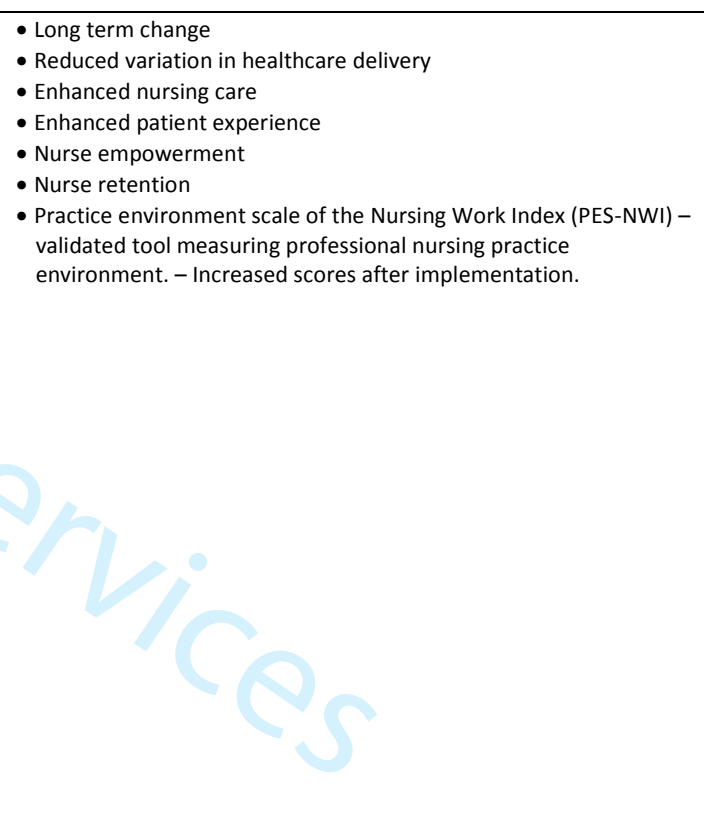 & $\begin{array}{l}\cdot \text { Nurses } \\
\text { : Patients } \\
\text { - Organisations }\end{array}$ & $\begin{array}{l}\text { Paper relatest to } \\
\text { implementation of a } \\
\text { care deliery system in } \\
\text { Army corps and impact } \\
\text { of this mechanisisms } \\
\text { decsribe how the } \\
\text { change was facilitited }\end{array}$ \\
\hline $\begin{array}{l}4 \\
48 \\
49 \\
50 \\
51 \\
52 \\
53 \\
54 \\
55 \\
56 \\
57\end{array}$ & 17 & 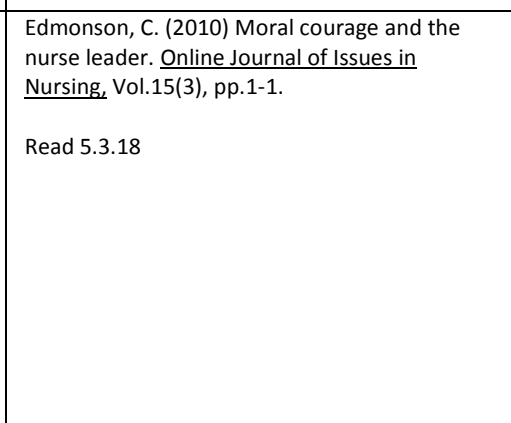 & \begin{tabular}{|l|} 
Peer review journal \\
Discussion paper
\end{tabular} & $\begin{array}{l}\text { Nurse leaders } \\
\text { Complex environments leading } \\
\text { to value cofficts and potential } \\
\text { for moral distresss }\end{array}$ & $\begin{array}{l}\text { - Develop, role model and practice moral } \\
\text { courage } \\
\text { - Result of dispositional factors (i.e. } \\
\text { characteristics) and situational factors } \\
\text { - Healthful work environments that support } \\
\text { moral courage } \\
\text { - create cultures that support courage in } \\
\text { nursing }\end{array}$ & 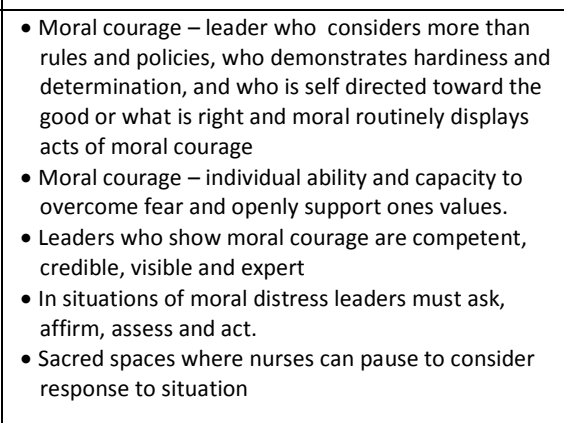 & - Prevent moral distress & - Nurses & $\begin{array}{l}\text { Lack of discussion } \\
\text { related to impact and } \\
\text { outcome. }\end{array}$ \\
\hline $\begin{array}{l}58 \\
59 \\
60\end{array}$ & 18 & 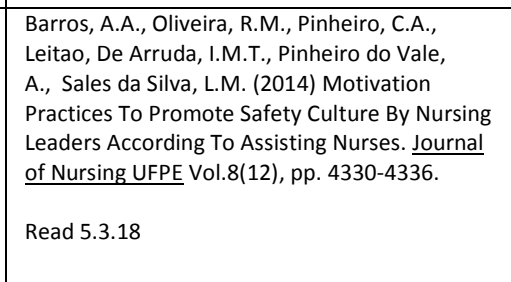 & \begin{tabular}{|l|l|} 
Peer review journal \\
Qualitative research
\end{tabular} & 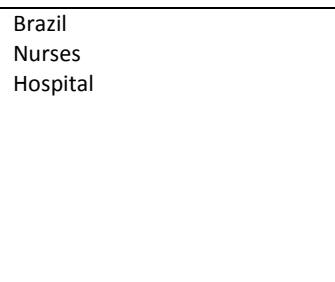 & $\begin{array}{l}\text { - Identify factors that promote a safety of } \\
\text { culture by nurse leaders - safety culture is } \\
\text { defined as the sum of } \\
\text { the individual or group values, attitudes, } \\
\text { perceptions, competencies and patterns of } \\
\text { - behavior that determine the commitment, } \\
\text { - style and ability of health organization in } \\
\text { - security management }\end{array}$ & 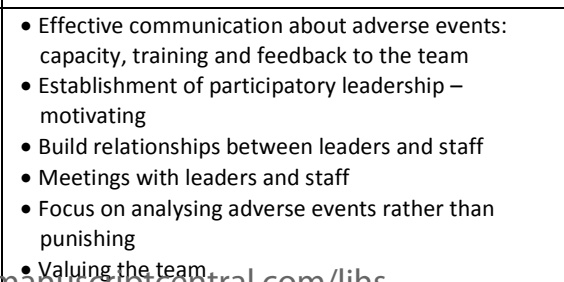 & $\begin{array}{l}\text { - Enhanced safety culture - reduced adverse events, hospital stay } \\
\text { - } \text { - Mot. }\end{array}$ & - patients & $\begin{array}{l}\text { Would be interessting if } \\
\text { therew was more detail } \\
\text { about the what and } \\
\text { how of particitipatory } \\
\text { leadership }\end{array}$ \\
\hline
\end{tabular}


9 Carlin, A., and Duffy, K. (2013) Newly qualified staff's perceptions of senior charge nurse roles.
Nursing Management. Vol.20(7), pp24-30. Read 5.3.18

20 Scott, J., Morales, D.R., McRitchie, A., Riviello, R., Smink, D., and Yule, S. (2016) Non-technica
skills and health care provision in low- and Siddle-income countries: a a ystematic review
Medical Education, Vol.50(4), pp.441-455 Read 5.3.18

21 Boynton, B. (2012) Nurse Leaders' Critical Role in and Collaboration Strategies for Creating
Safe, Positive Workplace Cultures. Journal of
Legal Nurse Consulting, Vol.23(2), p. 31 -34. Sadeal Postive Wor
Legal Read 5.3.18

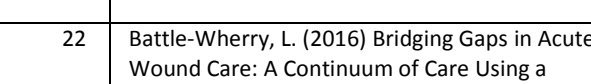
Wound Care: A Continum of Care Using a
Computerized Provider Order Entry System. Online Journal of I fursing Informatics,
Vol.20(1), p. 1-1. Read 8.3.18

\begin{tabular}{ll}
23 & $\begin{array}{l}\text { Sharkey, S., Lefebre, N. (2017) Bringing Nursing } \\
\text { Back to the Future Through People-Powered }\end{array}$ \\
\hline
\end{tabular} Care. Nursing Leadership Vol.30(1), pp.11-22. Read 8.3.18

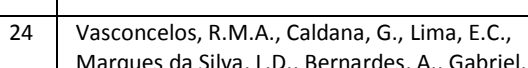
C.S. (2017) Communication In The Relations

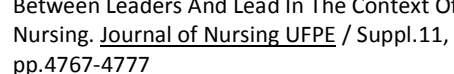
Read 8.3.18

- Participatory leadership - encourage shared
decision making - Participatory leadership - encourage shared
- Autision making
- Authors identify in problems with safety

- STRONG, EFFECTIVE and visible clinical - leadership at senior chargen nurse (SCN) level is - at the centre of the government's
modernisation

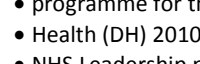
- NHS Leadership - NAS Leadership programme for SCN amongst
others (e.g. RCN) - however doubt over effectiveness of strategies
- Participants had diffiction Participants had difficulty in articulating the
rol the SCN with overlap between management and leadership roles

- Little is known about NTS in LMICs. - Study aims to explore contextual factors that affect their use - leadership being one of
these.

nursing leadership - Lack of leadership training in LMICS

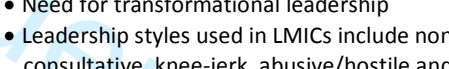
depowered.

- Context of patient safety and promoting
positivive work enviromments. LNCS trought in when there is a problem but have a role to to play in terms of leadership and prevention of - The Joint com - The Joint Comission (TIC) statistics on root
cause sentinel events - leaders is on commonly cited root cause - Humans as adaptive system

- Gaps in wound care management
- Varied approaches in wound management - Varied approaches in wound managemenent
protocols - Donabedian's model for quality - structure process and outcomes is the structure for Us - Transformational leadership

- 'People powered care' - engaging and
empowering nurses to engage and empower empowering nurses to engage and empo
patients patients
- HOPE model - focus on wellness and independence guidinin clinical
than number of vists. - Focus on human connections

\section{- Literature review aims to explore importance} of communication between leaders and the
led in nursinin - Importance of the process communication
led nurig. - Importance of he process communication
- dentified as an area for exploration
- Leadership competencec directly related to ability to communicate - Good leadership will ensure professionals
committed to the vision of the organiss

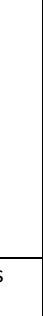

\begin{tabular}{|c|c|c|c|}
\hline $\begin{array}{l}\text { - Visibility of SCN on ward, clinical presence } \\
\text { - Support of leader to be able to make autonomous } \\
\text { decisions } \\
\text { - Emotional support in the form of praise } \\
\text { - Leaders as nurturers } \\
\text { - Role modelling - clinical and being with patients - } \\
\text { - beliefs and davilues } \\
\text { - Approachability of leader - facilitating concept of } \\
\text { belongingness }\end{array}$ & - Job satisfaction, retention & - Nurses & 5 participants \\
\hline $\begin{array}{l}\text { - Cross over with management } \\
\text { - Organising, planning tasks } \\
\text { - Developing teamworkt/tam skills } \\
\text { - Developing a positive atmosphere }\end{array}$ & $\begin{array}{l}\text { - Nurses more satisfied witt transformational leadership } \\
\text { - Improved nursing leadership = improved patient safety }\end{array}$ & & $\begin{array}{l}\text { What does 'smproved' } \\
\text { nursing leadership } \\
\text { mean? }\end{array}$ \\
\hline $\begin{array}{l}\text { - Healthy communication skills - including } \\
\text { assertivenesss respectful listening e.g. asking for, } \\
\text { offering and accepting help; setting limits; } \\
\text { respecting self and others. } \\
\text { - Building trust and healthy relationships } \\
\text { - Develop a plan with vision, commitment and } \\
\text { consensus building } \\
\text { - Incorporate training and practice - around } \\
\text { respectful listening and speaking up, healthy } \\
\text { communication, managing conflict } \\
\text { - Coachinin, rolele modelling } \\
\text { - Discipline }\end{array}$ & - Safe positive workplace cultures & $\begin{array}{l}\text { - Patients - safe care } \\
\text { - Organisations }\end{array}$ & \\
\hline 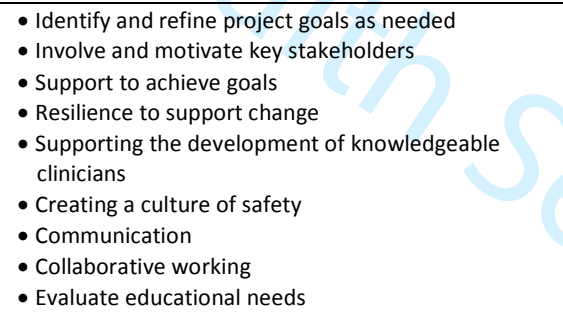 & \begin{tabular}{|l} 
- 20\% decrease in pressure ulcer incidence in test site \\
- Improved care delivery \\
$\cdot$ Standardised documentation
\end{tabular} & $\begin{array}{l}\text { - Healthcare staff } \\
\text { Patitents } \\
\text { - Organsation }\end{array}$ & \\
\hline $\begin{array}{l}\text { - Co-design } \\
\text { - Proactive in creating and sustaining the culture and } \\
\text { responsive to needs goals and desires of people } \\
\text { Courgaeous } \\
\text { Experiment with new approaches on the go } \\
\text { - Championinin new models of healthcare } \\
\text { Expert communication } \\
\text { - Transformativiv leaders explore the tensions } \\
\text { between being bold and humble }\end{array}$ & \begin{tabular}{|l} 
- Increased patient satisfaction \\
B Better alignment between those accessing the service and those \\
delivering
\end{tabular} & - patients & $\begin{array}{l}\text { llike how this paper is } \\
\text { written. }\end{array}$ \\
\hline $\begin{array}{l}\text { - communication, commitment, responsibility, } \\
\text { empathy, ability } \\
\text { - to decision-making, and management } \\
\text { effectively } \\
\text { - Open direct and transparent communication } \\
\text { - Involving team members in the decision making } \\
\text { process. } \\
\text { - Theoeretical and practical knowledge } \\
\text { - Motivation and dedication } \\
\text { - Ability to listen and speak and practicality in conflict } \\
\text { resolution } \\
\text { - Dialogic communication } \\
\text { Participatory leadership } \\
\text { - Leadership training } \\
\text { - Authentic dialogue with team with the purpose of } \\
\text { sharing ideas and vision } \\
\text { - Value less hierarchical communication }\end{array}$ & $\begin{array}{l}\text { - Good team relationships } \\
\text { - Promote desired changes in work environment } \\
\text { : uuality saf care } \\
\text { - Staff satisfaction }\end{array}$ & $\begin{array}{l}\text { - Patients } \\
\text { - Staff } \\
\text { - Organisation }\end{array}$ & \\
\hline 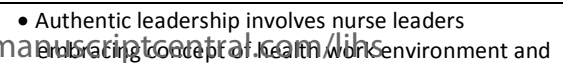 & \begin{tabular}{|l|} 
- Staff satisfaction and retention \\
- Enhanced patient safety and qua
\end{tabular} & $\begin{array}{l}- \text { Patients } \\
\text { - Staff }\end{array}$ & $\begin{array}{l}\text { Note link between } \\
\text { reduced access to }\end{array}$ \\
\hline
\end{tabular}


33 Roberts-Turner, R., Hinds, P.S., Nelson, J., Pryor, J, Robinson, N.C. and Wang, I. (2014)
Effects of Leadershii Characacteristics on Pediatric Registered Nurrses' ob Satisfaction
Pediatric Nursing Vol.40(5), pp.236-256. Read 14.3.18

Waite, R., and Mckinney, N.S. (2014) Enhancing
Conflict Competency ABNF Journal, Vol. 25(4), p. $123-128$.

Read 14.3.18

35 Curtis, E, and Connell, O.A. (2011) Essential leadership skills for motivating and developin
staff Surssing Management - UK. Vol.18(5),
pp.32-35. Read 15.3.18

36 Tomlinson, J. (2012) Exploration of transformational and distributed leadership.
Nursing Management - UK, vol.1944), pp.30-34. Read 15.3.18

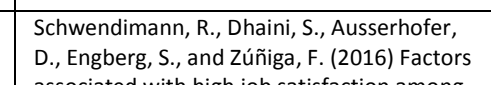
D., Engberg, S., and Zúníiga, F. (2016) Factors
associated with high job satisfaction among
cers care workers in Swiss nursing homes --a cross
sectional survey study. BMC Nursing. Vol.15,
pp. 1-10. Read 15.3.18

\begin{tabular}{|c|c|}
\hline $\begin{array}{l}\text { Peer review } \\
\text { Case study }\end{array}$ & $\begin{array}{l}\text { Ireland } \\
\text { Emergency department } \\
\text { Introduction of new short stay } \\
\text { unit }\end{array}$ \\
\hline $\begin{array}{l}\text { Peer review journal } \\
\text { Description of curriculum of } \\
\text { leadership programme and } \\
\text { mixed methods evaluation }\end{array}$ & $\begin{array}{l}\text { America } \\
\text { Critical Care Nurses }\end{array}$ \\
\hline $\begin{array}{l}\text { Peer review journal } \\
\text { Research- survey- } \\
\text { qualitative and quantitative }\end{array}$ & $\begin{array}{l}\text { America } \\
\text { Paediatric nurses }\end{array}$ \\
\hline $\begin{array}{l}\text { Peer review journal } \\
\text { Research- non- } \\
\text { experimental pre- and post- } \\
\text { survey design }\end{array}$ & $\begin{array}{l}\text { Underergaduate nursing } \\
\text { students } \\
\text { America }\end{array}$ \\
\hline $\begin{array}{l}\text { Peer review journal } \\
\text { Discussion paper }\end{array}$ & $\begin{array}{l}\text { Ireland } \\
\text { Nurses }\end{array}$ \\
\hline $\begin{array}{l}\text { Peer review journal } \\
\text { Research - interpretivist }\end{array}$ & \begin{tabular}{|l|}
$\begin{array}{l}\text { Scotland } \\
\text { Nursing }\end{array}$ \\
\end{tabular} \\
\hline $\begin{array}{l}\text { Peer review journal } \\
\text { Quantitative research }\end{array}$ & \begin{tabular}{|l|} 
Switzerland \\
Nursing homes
\end{tabular} \\
\hline
\end{tabular}

- Adopting Lewin's (1951) 3 stage approach to

- Motivation and ability to motivate others - Assertiveness
care of how the short stay unit would improve - Willingness to engage with all staff
- Emotional intelligence

- American Association of Critical Care Nurses staff nurse leadership programme -16 month
programme
Hospitals chosen to participate were granted - Hospitals chosen to participate were granted
$\$ 10000$ to backfill shifts etc to support project \$10000 to backill
cohort approach

- ob satisfaction among RN in hospitals is - RN Shortage

- Lack of research focussing specifically on job

satisfaction amongsts peediatric nurses
Research available showed that lack of

leadership support hrowudted in poor
latisfaction with job satisfaction with job.
This study aimed to

Mils study aimed to explore leadership
characteristics and job satisfaction in

paediatric RNs.
- Study guided by full range leadership theory - Study guided by full range leadership theor
which identifies transformational and Iransactional leadership as influencing followers in positive ways

- Seeing conflict as potentially positive - -i.e.
rather than negative injury, energising and an opportunity for growth
Undergraduate leadership programme Undergraduate eadereship programme
specifically yxploring changes in conflict style. - Paper discusses link between transformational
leadership and motivation 作

- Need to restore public faith in healthcare - Introduction of 'modern matron'
- Leading better care - introduction - charge netter care - introduction of senio - Government policies highlighting motivation, morale and ultimately care

- Research tends to focus on job satitifaction in
cuute care settings with a lack of rescartch acute care settings with a lack of research on
factors that influence job satisfaction in nursing homes Ongoing gocietal and demographic changes
leading to to increased demana for nursing - High turnover rates in nursing homes (uriculum empowers and engages staff nurses in quality improvement and evidence translation
change strategies, leadership skills - John Kotter's s step change theory (has been change in communication, vision ande empowerrme
contion - Communicating and embedding a vision
- Staff are mentored through a change project - Interactive and experiential - Internal cosach to subsed communication

Thentomite Transformational leadership - creating an
environment allowing individuals to perform at their
fullest potential - recognised by autonomy. - process - achieving organisisational goals in exchan vard - relates to distributive justice

\section{- Didactic and experiential activities to enhance} leadership development
- Reflective journaling, team building exercise - Thomas-Kilmann Conflict mode instrument was used
to measure ans to measure conflict resolution styles - the basis

\section{Skilled communicat}

- Inspire trust

- Bass (1998) theory of transformatritional leaderstion dientifies 4 main components main components
Idealised influence where leaders are admired and respected
Inspiratitional motivation Intellectual stimulation

\section{- Arriculate a vision that can motivast individuals to} - Articulate a vision that can mot co
adapt to changing situations - Shared accountability, responsibility and power - Work enhancement - job enrichment $\mathrm{e}$. freedom), job enlargement (e.g. decreasi monotony, job rotation
- Role models

Empowerment - top down: delegation and accountability; bottom up: encoura d

- Clinical leadership education early in career - Engaging whole team - shared vision

- Distributed leadership can have a positive effect on

- Supportive leadership associated with high job nursing work index - PES-NWII) included:

- Sumport by supervisors

Back up in decision makir

- praise and recognititon criticism satisfaction - strongest association. Leaders

\begin{tabular}{|c|c|c|}
\hline $\begin{array}{l}\text {-Improved services } \\
\text { - Increase competence and professionalism of nursing } \\
\text { - Strong multidisciplinary team ethos }\end{array}$ & \begin{tabular}{|l|}
$\begin{array}{l}\text { Patients } \\
\text { Staff } \\
\text { Organisation }\end{array}$ \\
\end{tabular} & $\begin{array}{l}\text { Weak discussion of } \\
\text { outcomes. }\end{array}$ \\
\hline 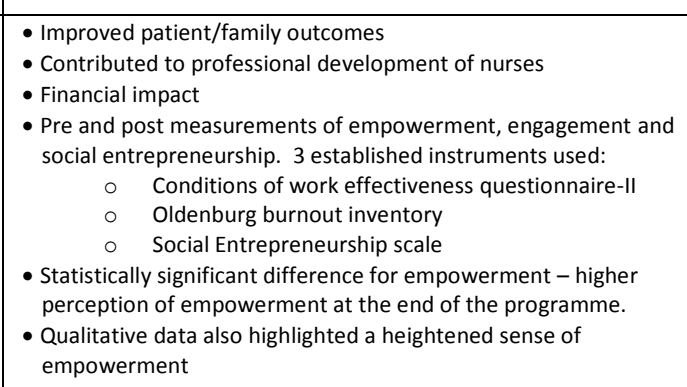 & \begin{tabular}{|l|} 
- Nurses \\
- Patients \\
- Organisations \\
\end{tabular} & $\begin{array}{l}\text { Highlight that patient } \\
\text { and financial outcomes } \\
\text { could ont necessarily } \\
\text { be wholly yttributed to } \\
\text { the leaderssipip } \\
\text { programme. }\end{array}$ \\
\hline 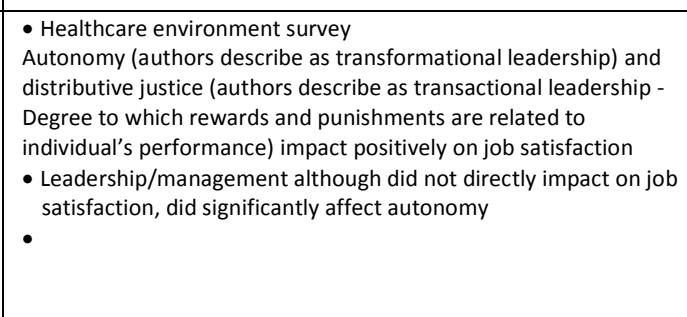 & - Nurses & 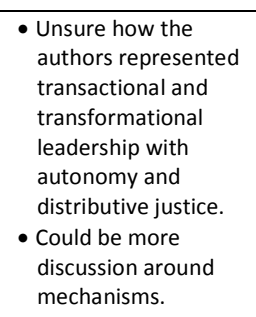 \\
\hline - Increased self awareness of conflict style & • Student & $\begin{array}{l}\text { - Vague findings and } \\
\text { discussion related to } \\
\text { impact of awerens } \\
\text { of conflict style }\end{array}$ \\
\hline $\begin{array}{l}\text { - Motivation and empowerment among nurses } \\
\text { - ingher leve of forformance } \\
\text { - Nurse retention }\end{array}$ & $\begin{array}{ll}\text {-Staff } \\
\text { - Organisation }\end{array}$ & \\
\hline $\begin{array}{l}\text { - Enhanced motivation, morale and performance of team } \\
\text { - Organisational goals met }\end{array}$ & \begin{tabular}{|l|} 
Staff \\
Patients \\
Organisation
\end{tabular} & \\
\hline $\begin{array}{l}\text { - High job satisfaction } \\
\text { - Enhanced resident care }\end{array}$ & $\begin{array}{l}\text { - Organisation/nursing home sector } \\
\text { • Staff } \\
\text { Residents }\end{array}$ & $\begin{array}{l}\text { Paper focusses on } \\
\text { what helus those to } \\
\text { feel aigh sense of job } \\
\text { satisfaction. } \\
\text { Appreciative focus } \\
\text { Refers to literature } \\
\text { that suggests variety of } \\
\text { leadership approaches } \\
\text { are ereneficial in in } \\
\text { nursinin homes- } \\
\text { sometimes more task } \\
\text { foccussed (Havig et al) }\end{array}$ \\
\hline
\end{tabular}




\begin{tabular}{|c|c|c|c|c|c|c|c|c|c|}
\hline dg & & & & & & 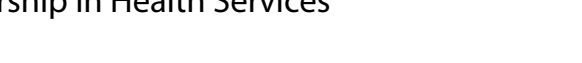 & & & \\
\hline${ }_{1}$ No & & Reference & tegory & & ntext & Mechanisms & Outcomes & Impact on whom & Notes \\
\hline $\begin{array}{l}3 \\
4 \\
5\end{array}$ & & & & & & $\begin{array}{l}\text { • Foster and maintain communication with front line } \\
\text { care workers, monitor needs and support } \\
\text { achievement of organisational gaols } \\
\text { - Reciprocal staff and management communication } \\
\text { - Support from colleagues I I would feel safe being a } \\
\text { resident in this unit' }\end{array}$ & & & \\
\hline $\begin{array}{l}8 \\
8 \\
9 \\
10 \\
11 \\
12 \\
13 \\
14 \\
15 \\
16 \\
17 \\
18 \\
19 \\
20 \\
21 \\
22\end{array}$ & 38 & 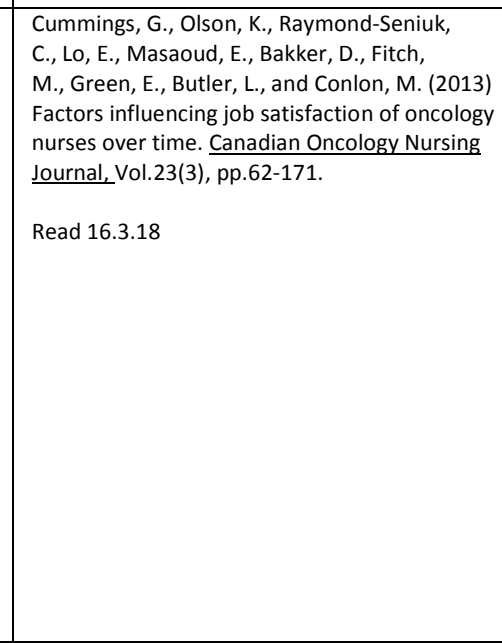 & \begin{tabular}{|l|l|} 
Peer review journal \\
Research - prospective \\
descriptive research design
\end{tabular} & $+\infty$ & 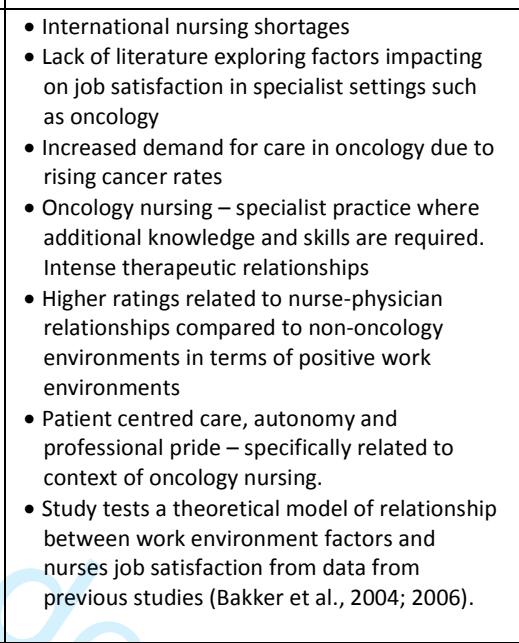 & 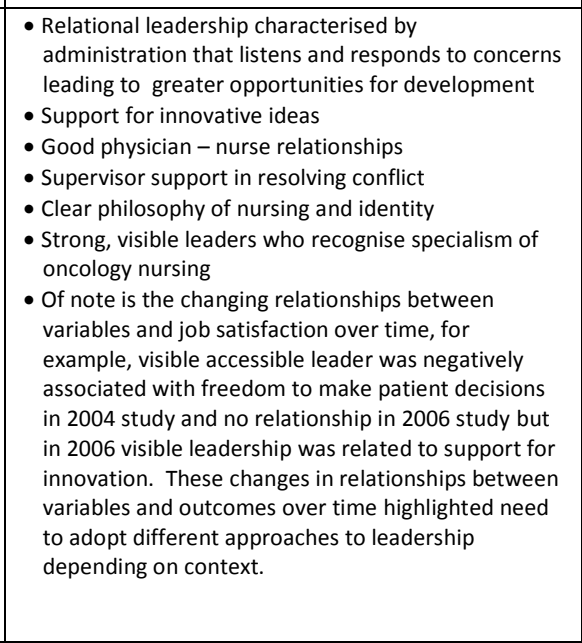 & 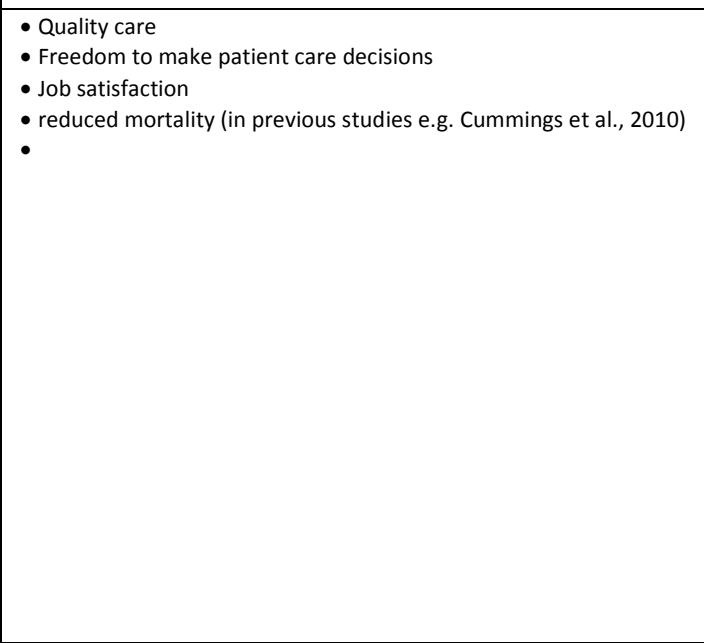 & \begin{tabular}{|l|} 
P Patients \\
- Nurses \\
- Organisation
\end{tabular} & \\
\hline $\begin{array}{l}23 \\
24 \\
25 \\
26 \\
27 \\
28 \\
29 \\
30 \\
31 \\
32 \\
33 \\
34 \\
35 \\
36 \\
37 \\
38 \\
39 \\
40 \\
41 \\
42 \\
43 \\
44\end{array}$ & 39 & 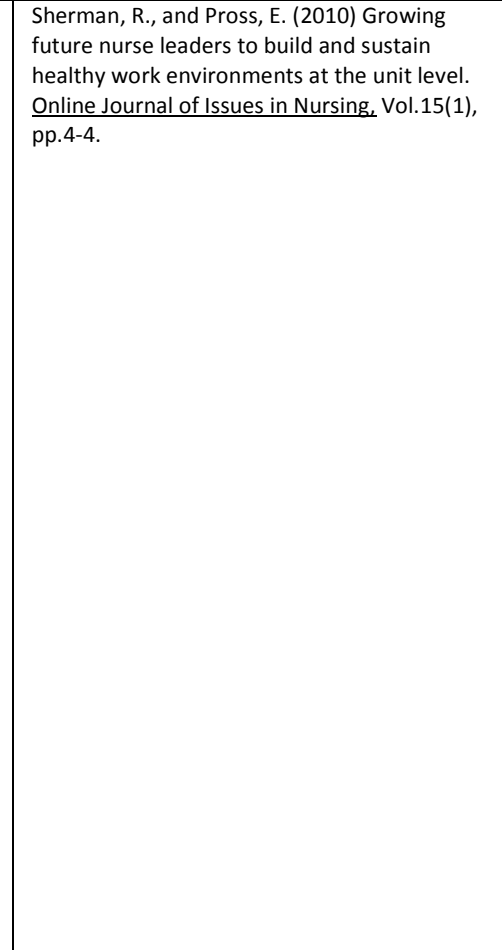 & \begin{tabular}{|l|l|} 
Peer review journal \\
Literature review
\end{tabular} & $\begin{array}{l}\text { America } \\
\text { Nursing }\end{array}$ & 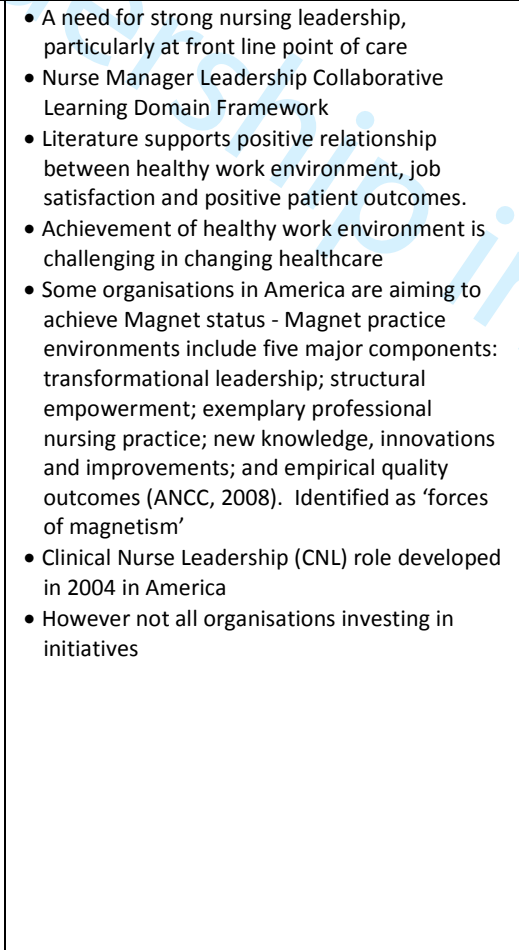 & 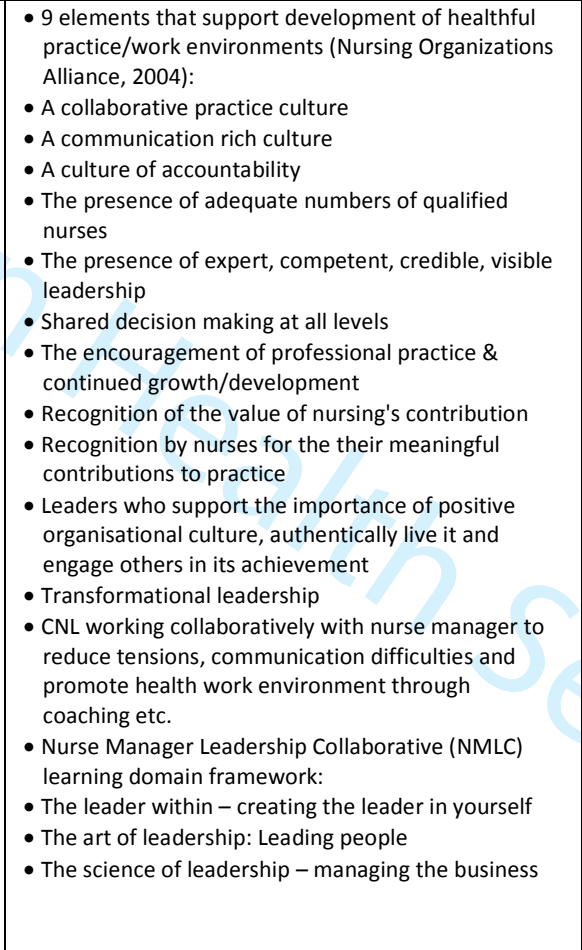 & $\begin{array}{l}\text { - Healthy work environments - higher job satisfaction, recruitment, } \\
\text { retention, improved patient outcomes }\end{array}$ & $\begin{array}{l}\text { - Nurses } \\
\text { OOrganisation } \\
\text { - Patients }\end{array}$ & \\
\hline $\begin{array}{l}45 \\
46 \\
47 \\
48 \\
49 \\
50 \\
51 \\
52 \\
53 \\
54 \\
55 \\
56 \\
57\end{array}$ & 40 & 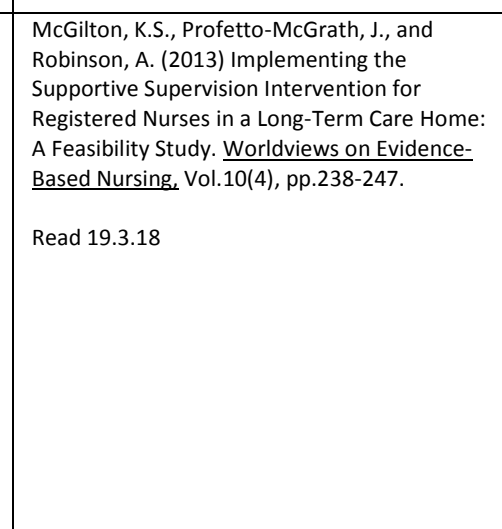 & \begin{tabular}{|l|} 
Peer review journal \\
Research - feasibility study \\
Quantitative - surveys and \\
focus groups
\end{tabular} & 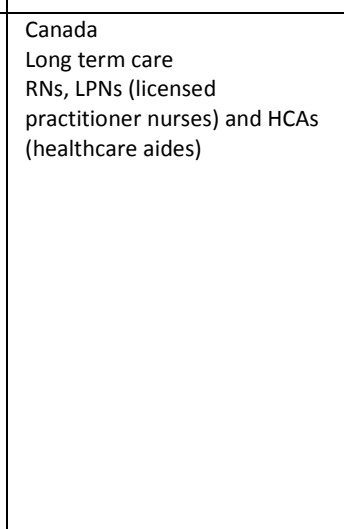 & 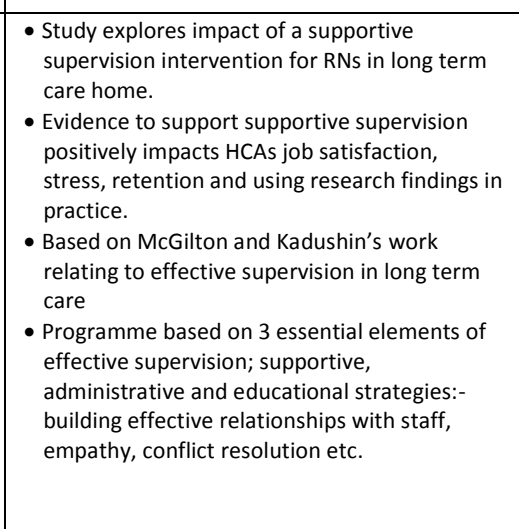 & $\begin{array}{l}\text { - Supportive supervision workshop } \\
\text { - Weekly reflection over } 6 \text { months - not seen feasible } \\
\text { by all staff. } \\
\text { •On-unit coaching over } 6 \text { weeks - this element did } \\
\text { not happen due to staffing problems }\end{array}$ & 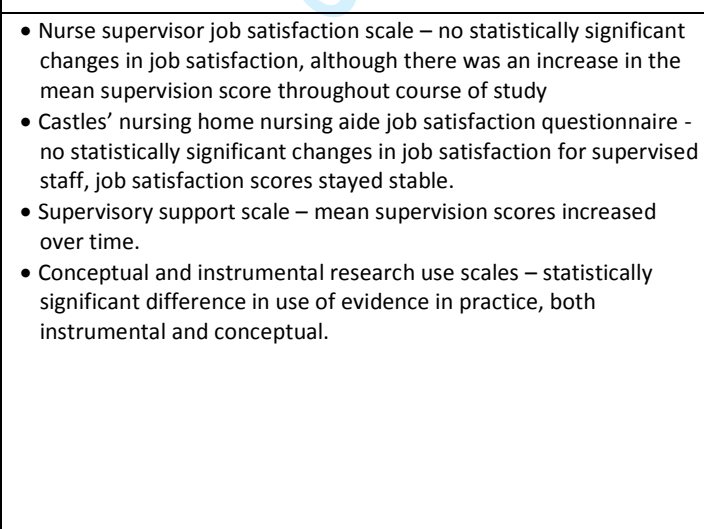 & $\cdot$ - Staff & \begin{tabular}{|l} 
Potential impact on \\
residents due to \\
enhanced use of \\
research athough this \\
was not documented.
\end{tabular} \\
\hline $\begin{array}{l}58 \\
59 \\
60\end{array}$ & 41 & $\begin{array}{l}\text { Coleman, C. (2013) Integrating Quality and } \\
\text { Breast Cancer Care: Role of the Clinical Nurse } \\
\text { Leader. oncology Nursing Forum, Vol.40(4), } \\
\text { pp.311-314. } \\
\text { Read 19.3.18 }\end{array}$ & \begin{tabular}{|l|} 
Peer review journal \\
Discussion paper
\end{tabular} & $\begin{array}{l}\text { Oncology nursing } \\
\text { USA }\end{array}$ & 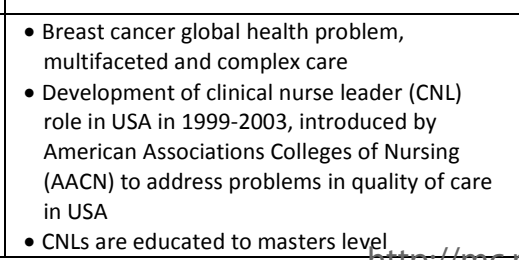 & $\begin{array}{l}\text { - Clinical microsystems - listening to staff working on } \\
\text { frontlinin with patients } \\
\text { - swot analysis for organisational assessment } \\
\text { - Advocate for overall organisational goals }\end{array}$ & $\begin{array}{l}\text { - Organisational effectiveness } \\
\text { - optimise client outcomes } \\
\text { - National accreditation Programme for breast centres }\end{array}$ & $\begin{array}{ll}\text { - Patients } \\
\text { Organisation }\end{array}$ & \\
\hline
\end{tabular}




\begin{tabular}{|c|c|c|c|c|c|c|c|c|c|}
\hline 1 No & & Reference & tegory & Setting & ntext & Mechanisms & Outcomes & Impact on whom & Notes \\
\hline $\begin{array}{l}2 \\
3 \\
4 \\
5 \\
6 \\
7 \\
8 \\
9\end{array}$ & & & & & 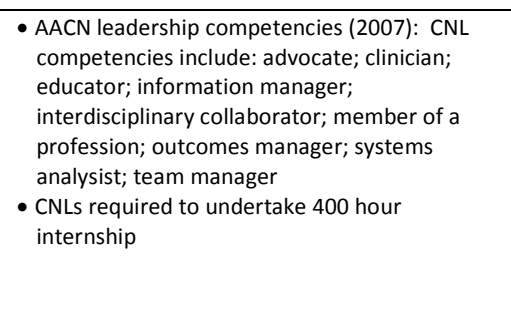 & & & & \\
\hline $\begin{array}{l}10 \\
11 \\
12 \\
13 \\
13 \\
14 \\
16 \\
16 \\
17 \\
18\end{array}$ & 42 & 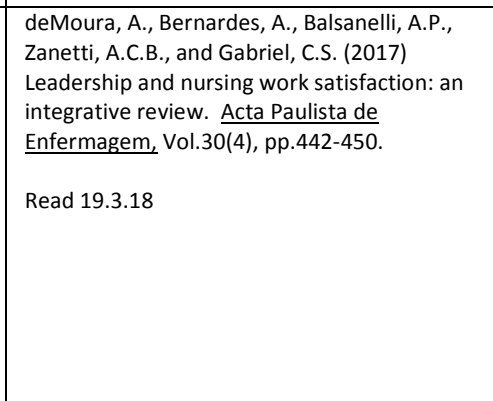 & $\begin{array}{l}\text { Peer review journal } \\
\text { Integrative review }\end{array}$ & $\begin{array}{l}\text { - Brazilian journal } \\
\text { - Nurning leadership and } \\
\text { relationship with job } \\
\text { satiffaction } \\
\text {-9/15 articles focussed on } \\
\text { hospital }\end{array}$ & $\begin{array}{l}\text { - Leadership is an essential competency in } \\
\text { nursing practice } \\
\text { - Theoretical basis for leadership: } \\
\text { transformational, authentic, resonant, task } \\
\text { orientated, situational } \\
\text { - Preparation for leadership role }\end{array}$ & 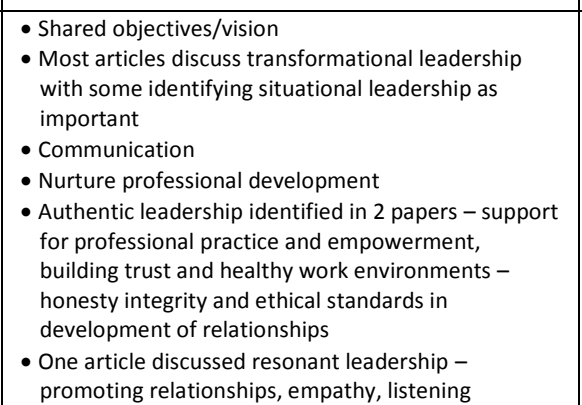 & 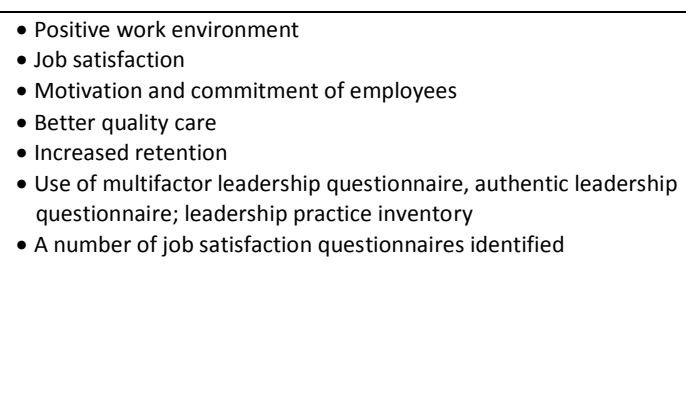 & $\begin{array}{l}\text { - Patients } \\
\text { - Nurses } \\
\text { - Organisation }\end{array}$ & 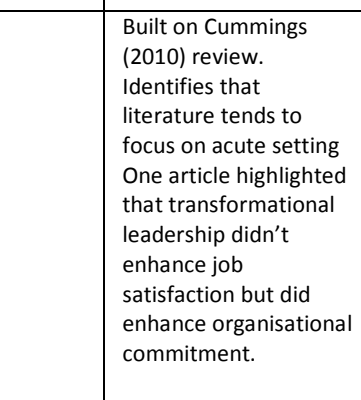 \\
\hline $\begin{array}{l}19 \\
20 \\
21 \\
22 \\
23 \\
24 \\
25 \\
26 \\
27 \\
28 \\
29 \\
30 \\
31 \\
32 \\
33 \\
34 \\
35 \\
36 \\
37 \\
38 \\
39 \\
40 \\
41 \\
42 \\
43 \\
44 \\
45 \\
46 \\
47\end{array}$ & 43 & $\begin{array}{l}\text { Hewison, A., and Morrell, K. (2014) Leadership } \\
\text { developm ment in the English National Health } \\
\text { Service: A counter naratative to inform policy. } \\
\text { International Journal of Nursing Studies, } \\
\text { Vol.51(4), pp.677-688. } \\
\text { Read 19.3.18 }\end{array}$ & $\begin{array}{l}\text { Peer review journal } \\
\text { Policy review paper }\end{array}$ & $\begin{array}{l}\text { NHS England } \\
\text { Leadership in healthcare } \\
\text { including nurses, AHPs etc. }\end{array}$ & 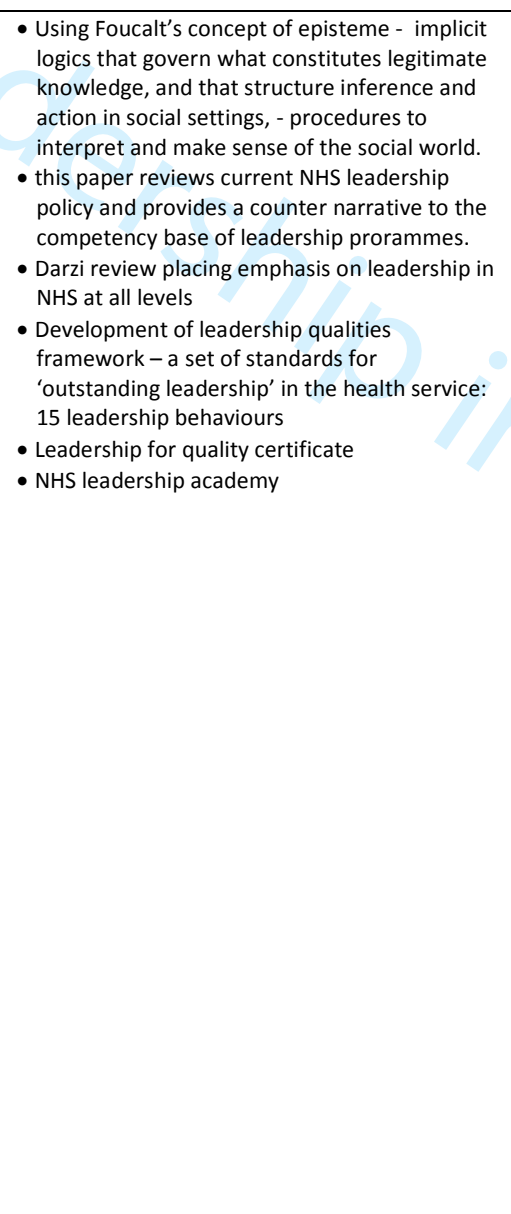 & 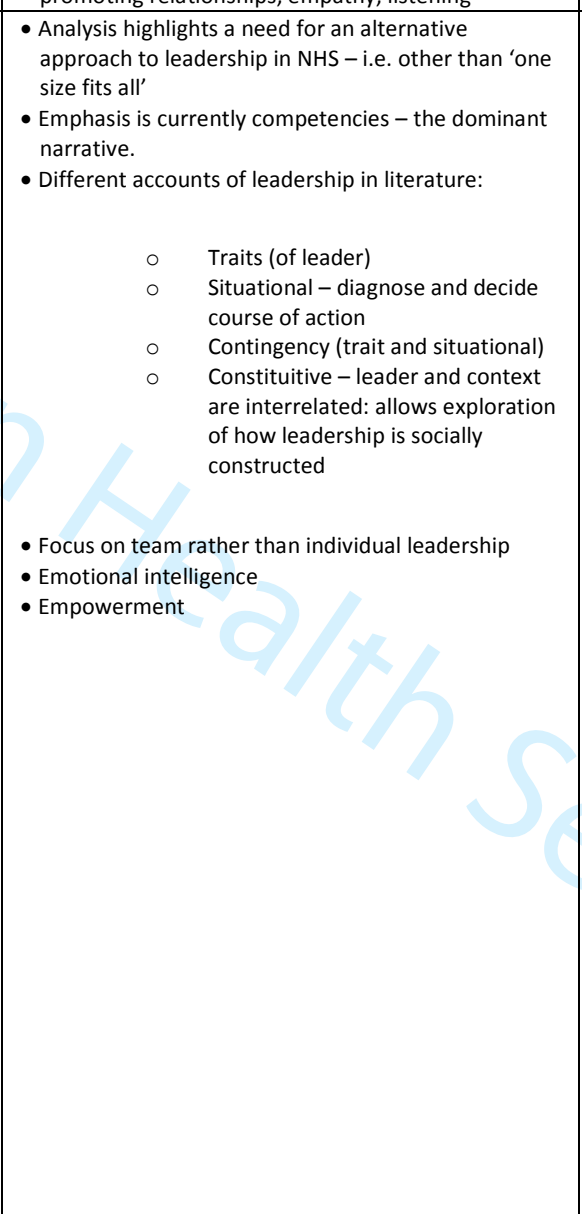 & - Enhanced patient care & $\begin{array}{l}\text { Organisation } \\
\text { Patients }\end{array}$ & $\begin{array}{l}\text { Interesting paper that } \\
\text { provides counter } \\
\text { narrative to idea of } \\
\text { competency vased } \\
\text { leadership that } \\
\text { underpins NHS. }\end{array}$ \\
\hline $\begin{array}{l}48 \\
49 \\
50 \\
51 \\
52 \\
53 \\
54 \\
55 \\
56 \\
57 \\
58 \\
59 \\
60\end{array}$ & 44 & \begin{tabular}{|l|} 
Morrison, $\mathrm{J}$. (2016) Nursing Leadership in ACO \\
Payment Reform. Nurring Economics. \\
vol.34(5), p. p.230-235. \\
Read 19.3.18
\end{tabular} & $\begin{array}{l}\text { Peer review journal } \\
\text { Discussion paper }\end{array}$ & $\begin{array}{l}\text { Nursing leadership } \\
\text { USA }\end{array}$ & $\begin{array}{l}\text { - Accountable Care organisations in context of } \\
\text { USA Healthcare reforms - valuevs sased } \\
\text { payment model aimed at improving quality } \\
\text { and coordination of care }\end{array}$ & 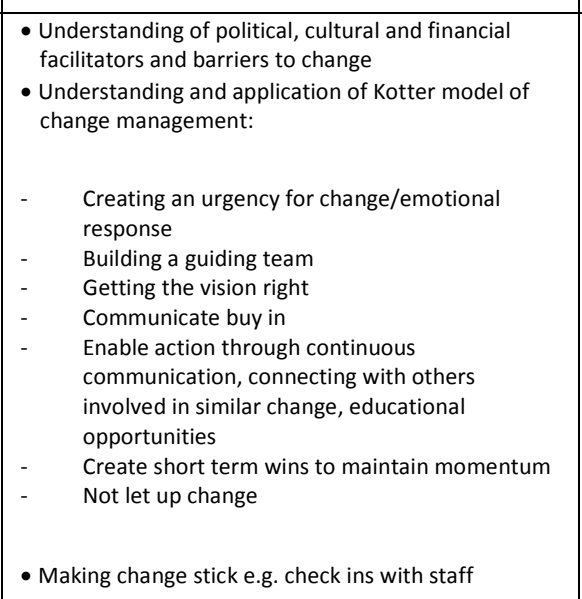 & - Successful organisational change & - Organisation & \\
\hline
\end{tabular}




\begin{tabular}{|c|c|c|c|c|c|c|c|c|c|}
\hline \multicolumn{10}{|c|}{ Impact on whom } \\
\hline $\begin{array}{l}2 \\
3 \\
4 \\
5 \\
6 \\
7\end{array}$ & 45 & 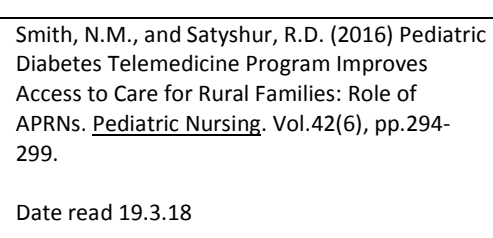 & $\begin{array}{l}\text { Peer review journal } \\
\text { Quantitative research }\end{array}$ & \begin{tabular}{|l|} 
Paediatric diabetes programme \\
for rural communities in \\
America \\
Role of Advanced Practice \\
Registered Nurses (APRNs) \\
\end{tabular} & 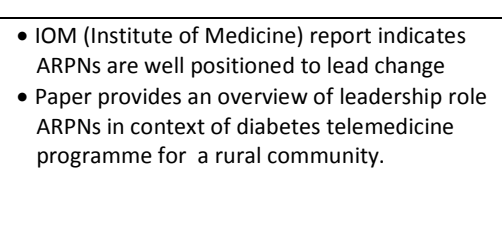 & $\begin{array}{l}\text { - APRNs provided technology expertise and led } \\
\text { interdisciplinary communication }\end{array}$ & $\begin{array}{l}\text { - Care giver satisfaction (telemedicine diabetes caregiver } \\
\text { satisfaction survey) }\end{array}$ & $\begin{array}{l}\text { - Caregivers } \\
\text { (parents/grandparents). }\end{array}$ & \\
\hline $\begin{array}{l}8 \\
9 \\
10 \\
11 \\
12 \\
13 \\
14 \\
15 \\
16 \\
17 \\
18 \\
19 \\
20 \\
21 \\
22 \\
23 \\
24 \\
25 \\
26 \\
27 \\
28 \\
29 \\
30 \\
31\end{array}$ & 46 & 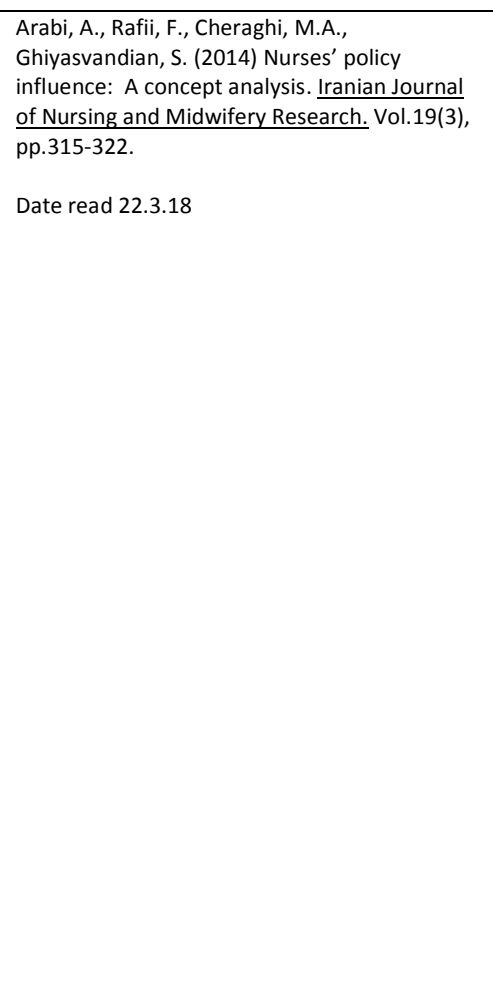 & $\begin{array}{l}\text { Peer review journal } \\
\text { Qualitative content analysis } \\
-8 \text { stage Walker and Avant } \\
\text { approach }\end{array}$ & $\begin{array}{l}\text { Nursing influence on policy } \\
\text { making } \\
\text { International context }\end{array}$ & 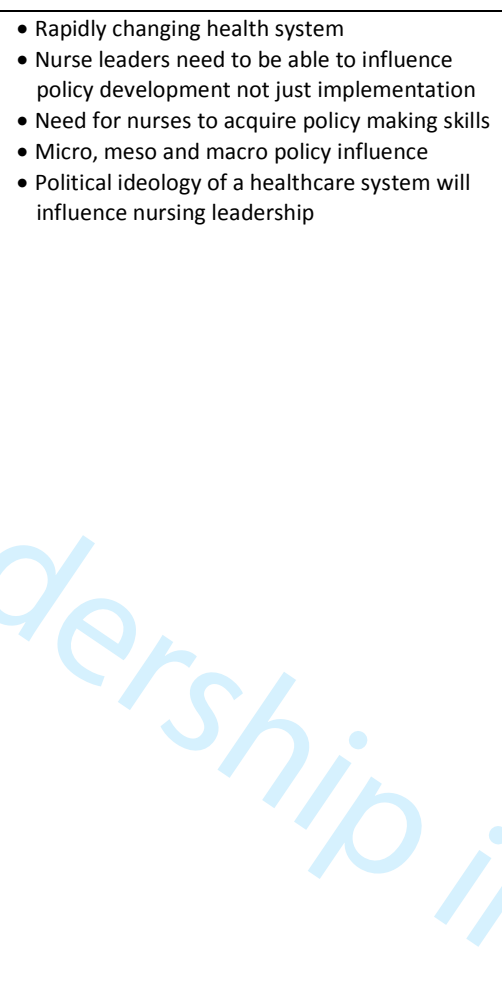 & 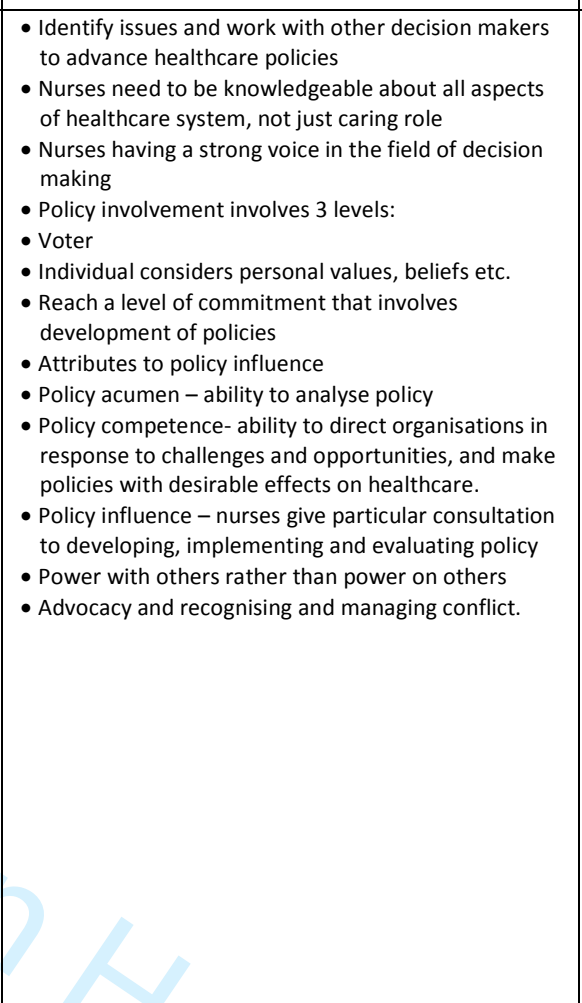 & $\begin{array}{l}\text { - Protect patient safety } \\
\text { - Increase quality of care, promoting quality of care }\end{array}$ & & 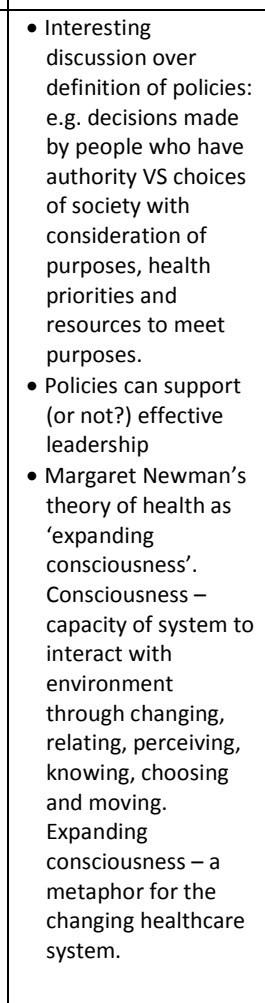 \\
\hline $\begin{array}{l}32 \\
33 \\
34 \\
35 \\
36 \\
37 \\
38 \\
39 \\
40 \\
41 \\
42 \\
43 \\
44 \\
45 \\
46 \\
47 \\
48\end{array}$ & 47 & 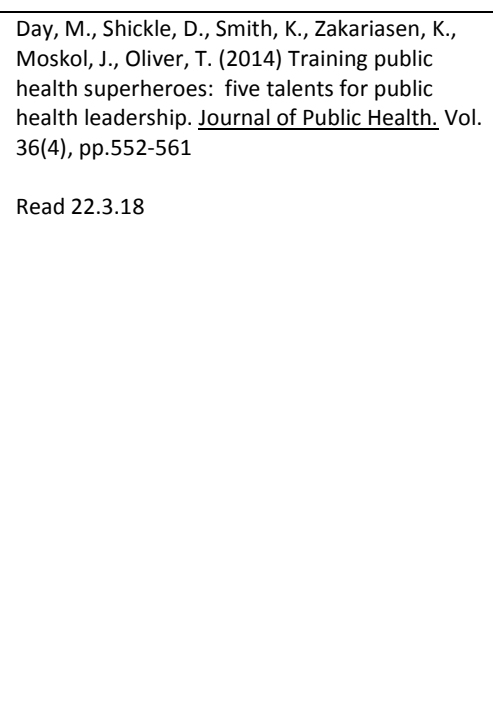 & $\begin{array}{l}\text { Peer review } \\
\text { Research - grounded theory }\end{array}$ & $\begin{array}{l}\text { Public health } \\
\text { UK Faculty of public health } \\
\text { members were asked to } \\
\text { identify their 'public cealth } \\
\text { superhero' - this led to } \\
\text { interviews to identify the } \\
\text { leadership talents } \\
\text { UK }\end{array}$ & 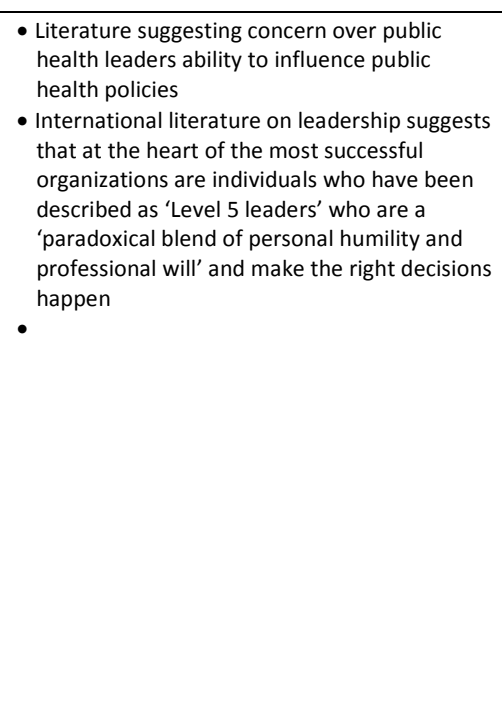 & 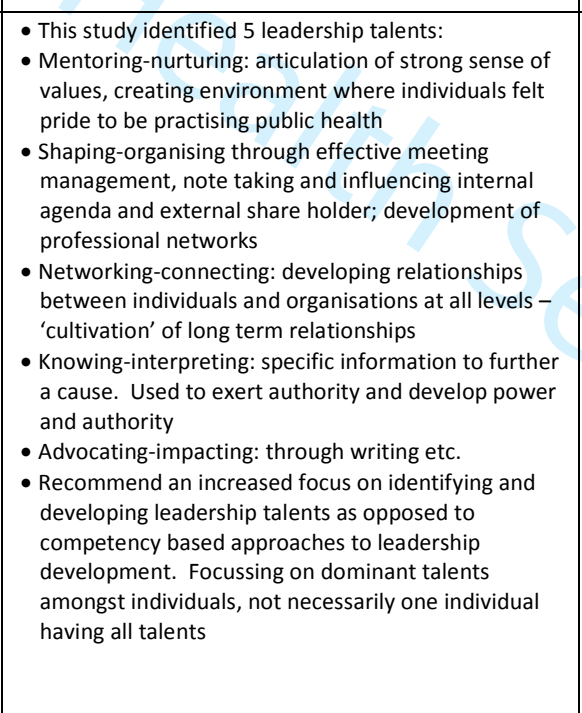 & - Strengthened public health leadership & $\begin{array}{l}\text { - Individuals working in public } \\
\text { heath } \\
\text { - Ultithately impacting on } \\
\text { population as a whole? }\end{array}$ & 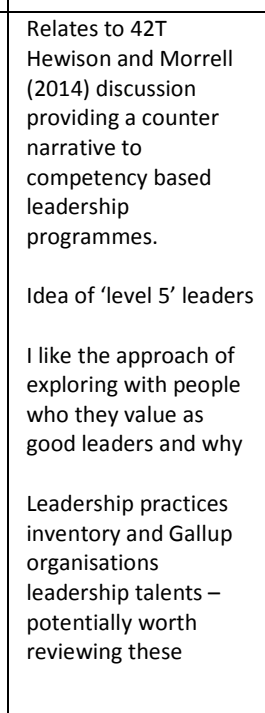 \\
\hline $\begin{array}{l}49 \\
50 \\
51 \\
52 \\
53 \\
54 \\
55 \\
56 \\
57 \\
58 \\
59 \\
60\end{array}$ & 48 & $\begin{array}{l}\text { Akerjordet, K., and Severinsson, E. (2008) } \\
\text { Emotionally intelligent nurse leaderships a } \\
\text { literature review studyy Journal of Nursing } \\
\text { Management. Vol.16, pp.565-577. } \\
\text { Read 23.3.18 }\end{array}$ & $\begin{array}{l}\text { Peer review journal } \\
\text { Literature review }\end{array}$ & - Nurse leaders & 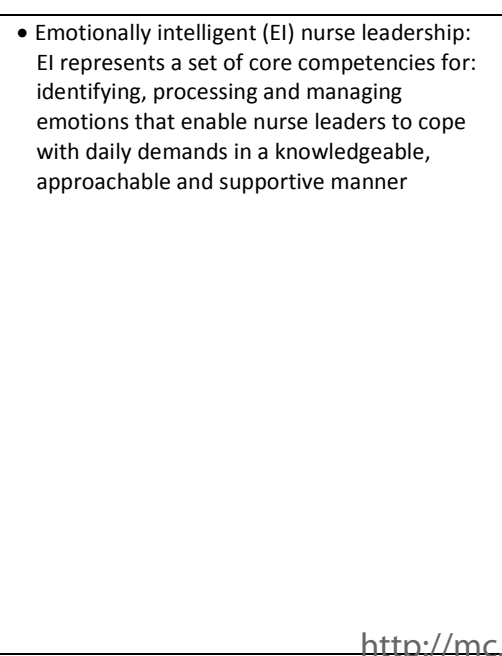 & 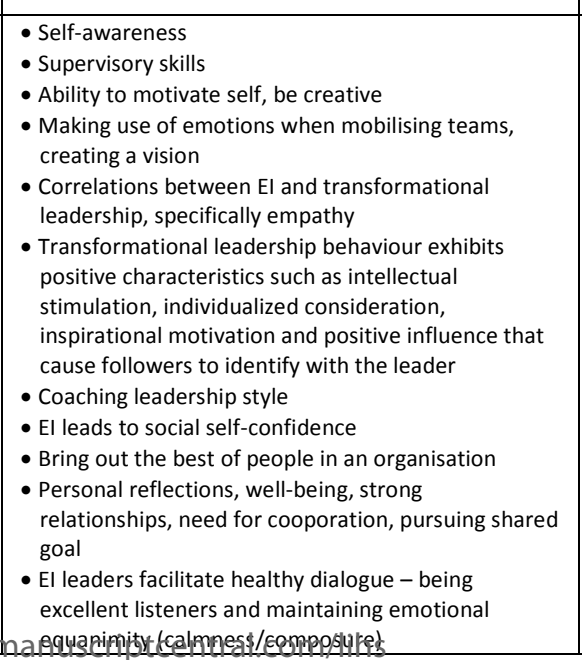 & 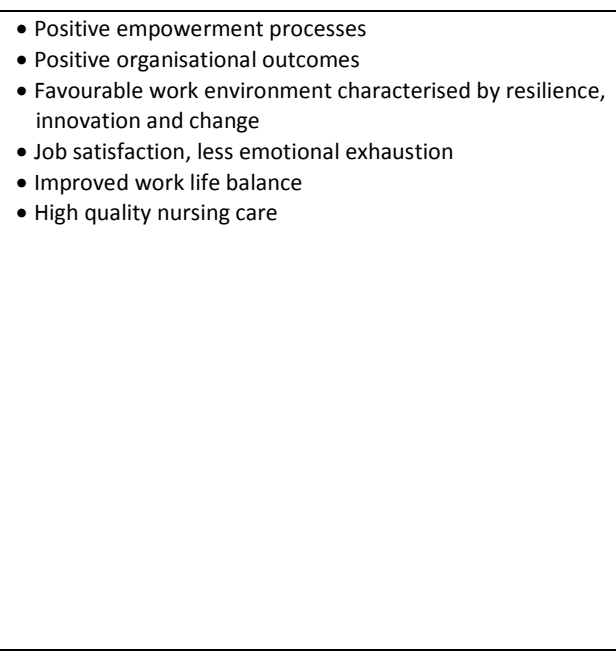 & $\begin{array}{l}\text { - Organisation } \\
\text { - Nurses } \\
\text { - Patients }\end{array}$ & 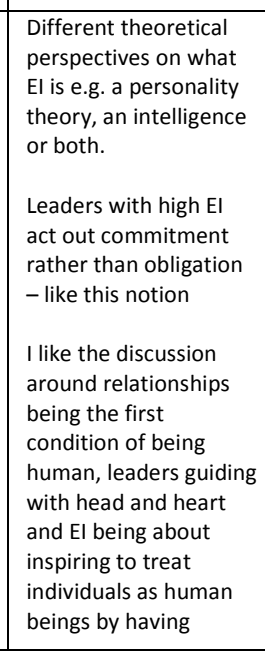 \\
\hline
\end{tabular}




\begin{tabular}{|c|c|c|c|c|c|c|c|c|}
\hline & & & & & - Continuous self reflection - inner supervision & & & $\begin{array}{l}\text { authentic empathy } \\
\text { (P.570) } \\
\text { Creativity being } \\
\text { enhanced when } \\
\text { people feel free and } \\
\text { respected }\end{array}$ \\
\hline 49 & 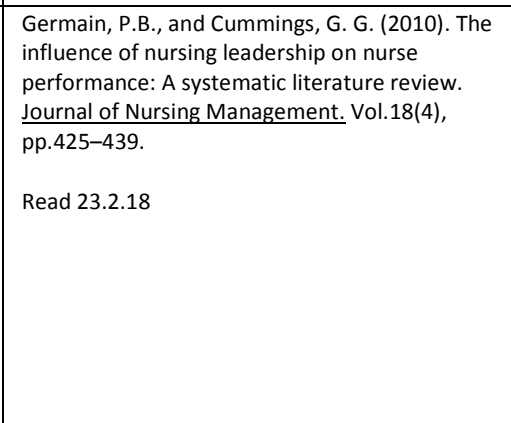 & $\begin{array}{l}\text { Peer review journal } \\
\text { Systematic literature review } \\
\text { and content analysis }\end{array}$ & 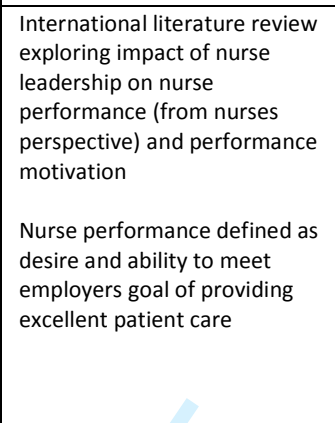 & 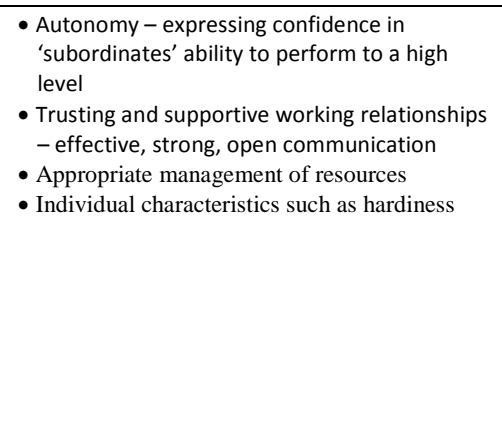 & 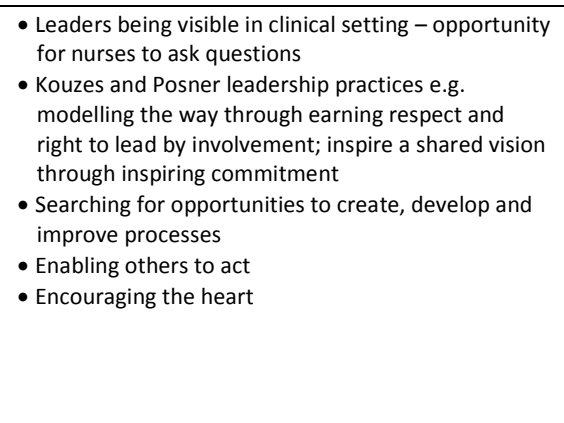 & 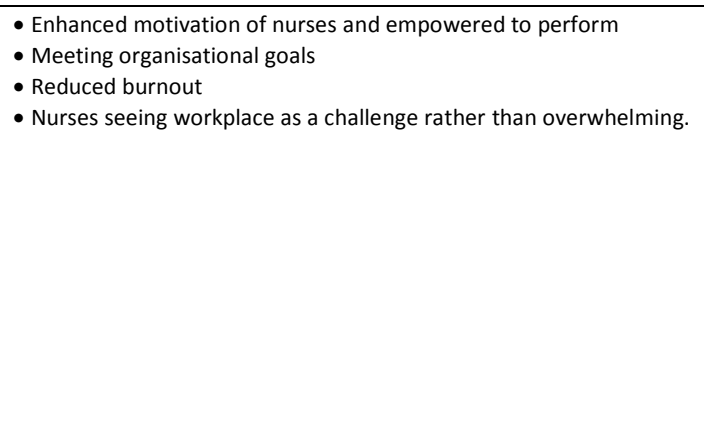 & $\begin{array}{l}- \text { Organisation } \\
\text { - Nursestion } \\
\text { - Patients }\end{array}$ & 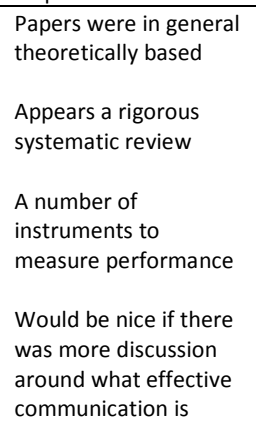 \\
\hline 50 & 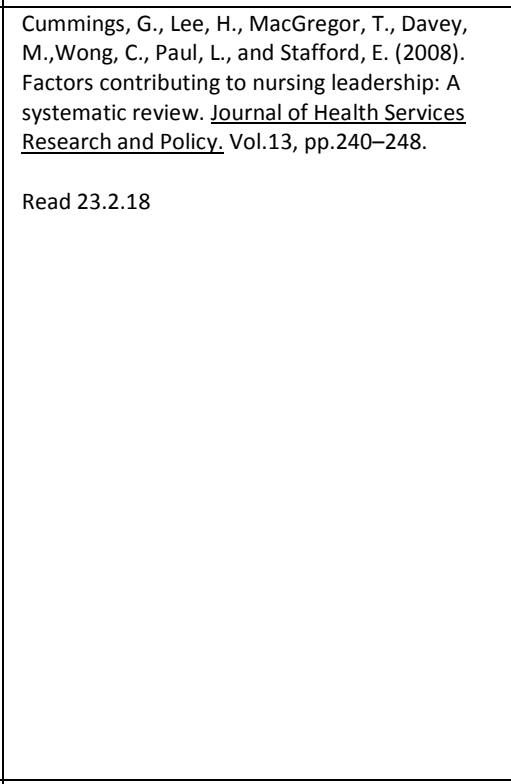 & $\begin{array}{l}\text { Peer review journal } \\
\text { Systematic review }\end{array}$ & $\begin{array}{l}\text { International review of factors } \\
\text { relating to positive nursing } \\
\text { leadership } \\
\text { Authors based in Canada }\end{array}$ & 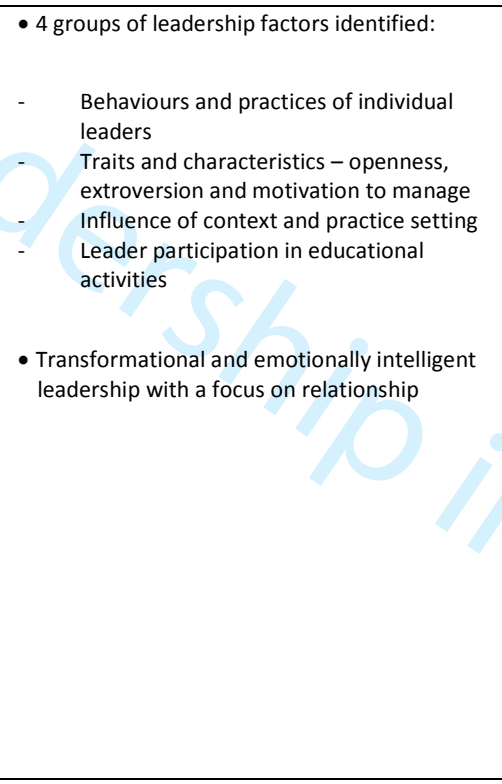 & $\begin{array}{l}\text { - Leadership can be developed through educational } \\
\text { activities and modelling and practising leadership } \\
\text { competencieis } \\
\text { - Relationship based competencies more effective } \\
\text { than financial } \\
\text { - Staff value more contact with leader } \\
\text { - Formal and informal leadership education related to } \\
\text { transformational leadership behaviours } \\
\text { - Leadership devel lodment programmers most } \\
\text { significant factor in increased leadership practices }\end{array}$ & $\begin{array}{l}\text { - Positive nursing leadership measured by a number of different } \\
\text { tools e.g. } \\
\text { - Leadership Practices Inventory } \\
\text { (three stsudies), Multifactor } \\
\text { Leadership Questionaire (two studies), Leader Behaviour } \\
\text { Descriptive Questionnaire } \\
\text { (three studies and the } \\
\text { Leadership effectiveness and Adaptability Description (two } \\
\text { studies). }\end{array}$ & $\begin{array}{l}\text { - Ultimately impacts on } \\
\text { individuals, patients and } \\
\text { organisation }\end{array}$ & 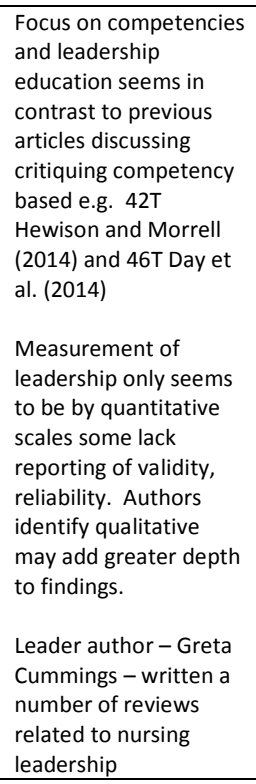 \\
\hline 51 & 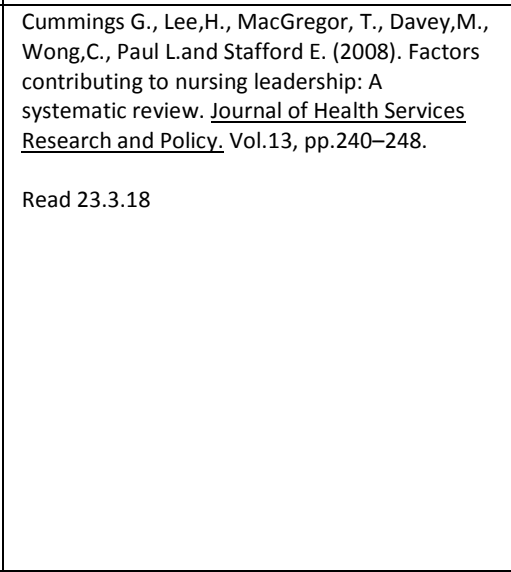 & $\begin{array}{l}\text { Peer review journal } \\
\text { Systematic review }\end{array}$ & 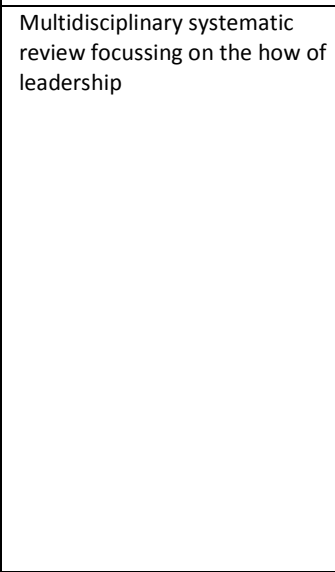 & $\begin{array}{l}\text { - Policy advocating strong leadership for } \\
\text { organisitional change but less focus on how } \\
\text { this is achieved }\end{array}$ & 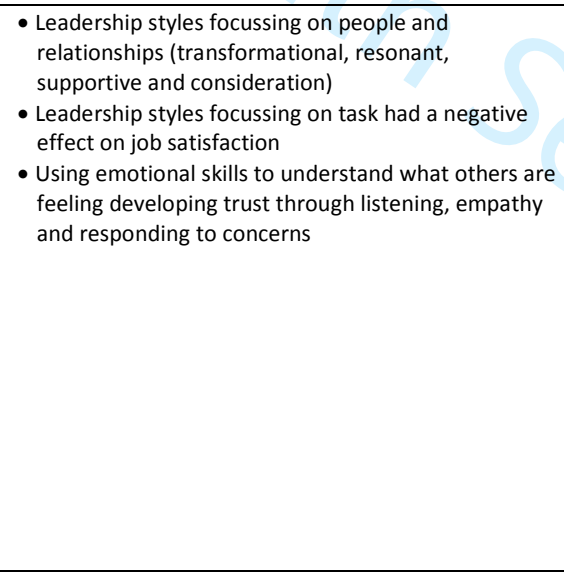 & $\begin{array}{l}\text { - Enhanced job satisfaction } \\
\text { - Organisational commitment } \\
\text { - Nurse empowerrment } \\
\text { - Intention to stay in post } \\
\text { Staff health } \\
\text { - Eurse research utilisation } \\
\text { - Enhanced teamwork between nurses and physicians }\end{array}$ & $\begin{array}{l}- \text { Organisations } \\
\text { Patients } \\
: \text { Healthare providers }\end{array}$ & $\begin{array}{l}\text { Multidisisiplinary } \\
\text { review cut focus on } \\
\text { nursing? } \\
\text { Review provides strong } \\
\text { arrument for } \\
\text { relationally focussed } \\
\text { leadership } \\
\text { Would have liked to } \\
\text { see more discussion on } \\
\text { the how of relational } \\
\text { leadership } \\
\text { Lead author - Greta } \\
\text { Cummings - written a } \\
\text { number of revews } \\
\text { related to nursing } \\
\text { leadership }\end{array}$ \\
\hline 52 & 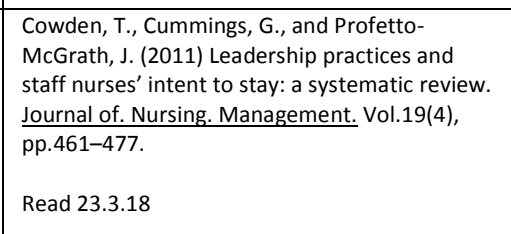 & $\begin{array}{l}\text { Peer review journal } \\
\text { Systematic review }\end{array}$ & $\begin{array}{l}\text { - Staff nurses and nurse } \\
\text { managers } \\
\text { - Various sites including } \\
\text { hospital, home care, state } \\
\text { - unrining associations } \\
\text { - International context }\end{array}$ & $\begin{array}{l}\text { - A need to retain staff nurses led to need to } \\
\text { explore relationship between leadership } \\
\text { practices and nurses intent to stay } \\
\text { - Relational leadership }\end{array}$ & $\begin{array}{l}\text { - Positive relationship between relational leadership } \\
\text { (transformational and intent to stay } \\
\text { - Recommend incorporating relational leadership } \\
\text { theory into management practices } \\
\text { - Empowering others }\end{array}$ & $\begin{array}{l}\text { - Increased intention to stay in role } \\
\text { - A variety of different tools used to measure intent to stay and } \\
\text { leadership }\end{array}$ & $\begin{array}{l}- \text { Nurses } \\
\text { - Organisation }\end{array}$ & $\begin{array}{l}\text { Another paper by } \\
\text { Gretac cummings that } \\
\text { highlight value of } \\
\text { transfor ational } \\
\text { leadership - would } \\
\text { again be intersting to } \\
\text { hear more of the 'how' }\end{array}$ \\
\hline 53 & 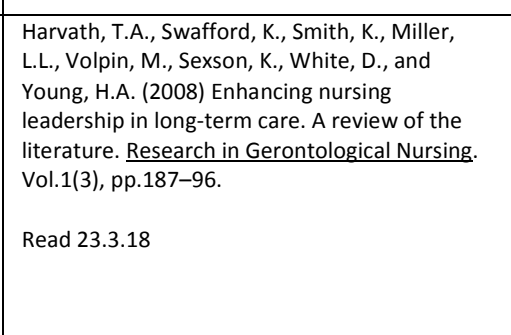 & $\begin{array}{l}\text { Peer review journal } \\
\text { Review of literature }\end{array}$ & $\begin{array}{l}\text { - Long term care } \\
\text { - Nursing leadership }\end{array}$ & $\begin{array}{l}\text { - Evidence that quality of care in nursing homes } \\
\text { can be enhanced by nursing leadership } \\
\text { - Need to develo leadership skills in nursing } \\
\text { homes }\end{array}$ & 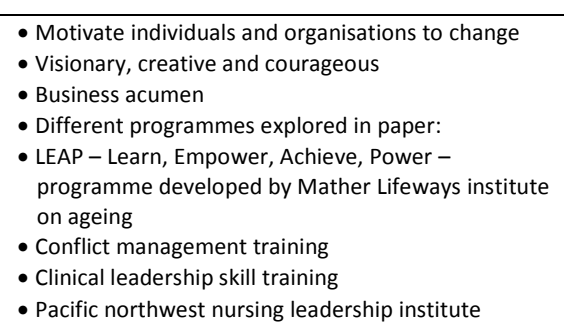 & $\begin{array}{l}\text { - Notet that evidence on outcomes is weak } \\
\text { - Empowerment } \\
\text { - Leadershipe effectiveness } \\
\text { - Organisational climate } \\
\text { - Dob satisfaction } \\
\text { - Work effectiveness } \\
\text { - Intent to stay }\end{array}$ & - Not clear & $\begin{array}{l}\text { Review identifies that } \\
\text { evidence that } \\
\text { leadership } \\
\text { programmes enhance } \\
\text { leadership in long term } \\
\text { care is weak. } \\
\text { Paper is } 10 \text { years old - } \\
\text { develoments such as } \\
\text { MHL since! }\end{array}$ \\
\hline
\end{tabular}




\begin{tabular}{|c|c|c|c|c|c|c|c|c|c|}
\hline${ }_{1}^{\text {No }}$ & & Reference & tegory & & ntext & Mechanisms & Outcomes & Impact on whom & \\
\hline $\begin{array}{l}3 \\
3 \\
4 \\
5 \\
6 \\
7 \\
7 \\
8 \\
9\end{array}$ & & & & & & & & & 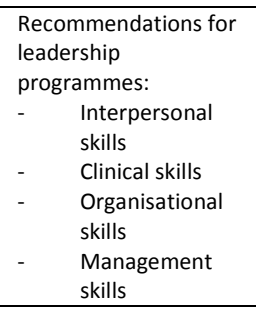 \\
\hline $\begin{array}{l}10 \\
11 \\
12 \\
13 \\
14 \\
15 \\
16 \\
17 \\
18 \\
19 \\
20 \\
21 \\
22 \\
23\end{array}$ & 54 & \begin{tabular}{|l} 
Krugman, M., Rudolph, M., Nenaber, A., and \\
Dietrich, , . (2013) Clinical stars lead a \\
successful professional practice programme, \\
American Nurse Today. Vol.8(9), pp.46-50 \\
Read 5.4.18
\end{tabular} & Discussion paper & America & 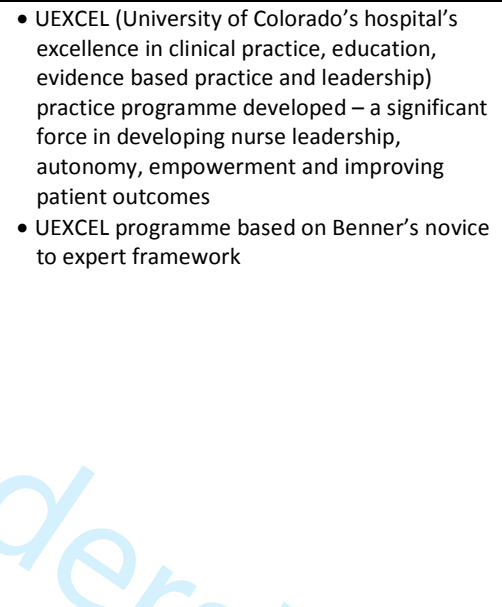 & 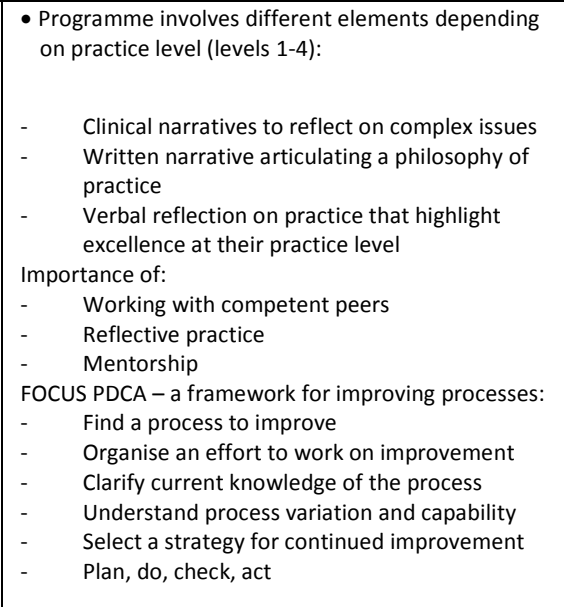 & $\begin{array}{ll} & \text { Organisation - achievement of magnet status } \\
: & \text { Nurses } \\
\text { Staff }\end{array}$ & & \\
\hline $\begin{array}{l}24 \\
25 \\
26 \\
27 \\
28 \\
29 \\
30 \\
31 \\
32 \\
33 \\
34 \\
35 \\
36\end{array}$ & 55 & 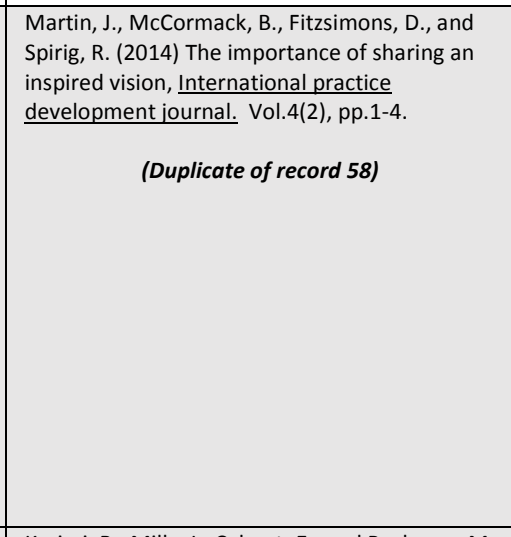 & $\begin{array}{l}\text { Research } \\
\text { Qualitative phase of a Mixed } \\
\text { methods study }\end{array}$ & Switzerland & 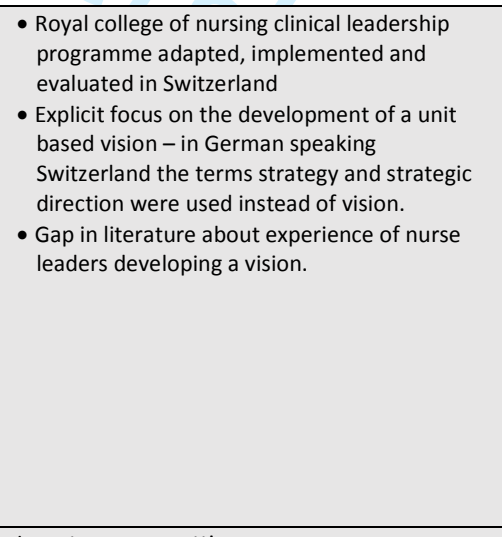 & 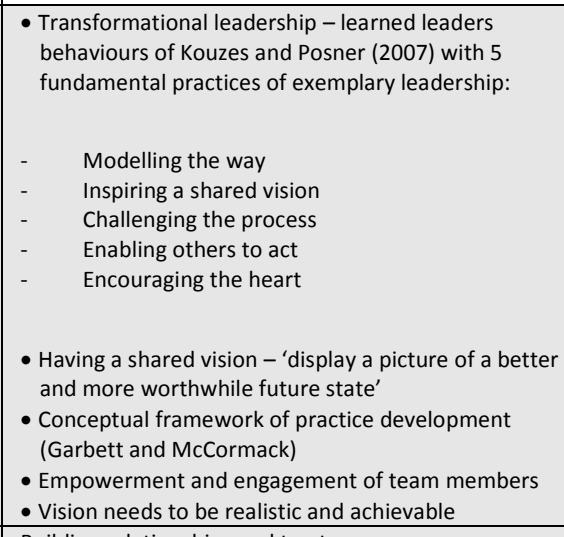 & $\begin{array}{l}\text { - High quality care } \\
\text { Effective workplace culture } \\
\text { - Increased motivation, energy and commitment of staff } \\
\text { - Move from traditional to evidence based practice }\end{array}$ & $\begin{array}{l}\text { - Nurses } \\
\text { - Patients } \\
\text { - organisation }\end{array}$ & 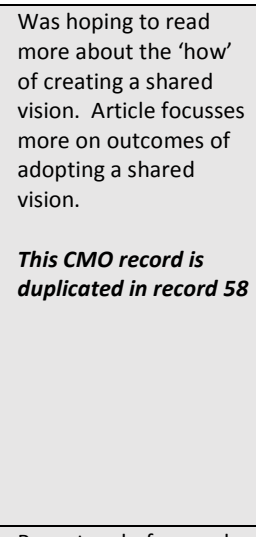 \\
\hline $\begin{array}{l}37 \\
38 \\
39 \\
40 \\
41 \\
42 \\
43 \\
44 \\
45 \\
46 \\
47 \\
48 \\
49 \\
50 \\
51 \\
52 \\
53 \\
54 \\
55 \\
56\end{array}$ & 56 & 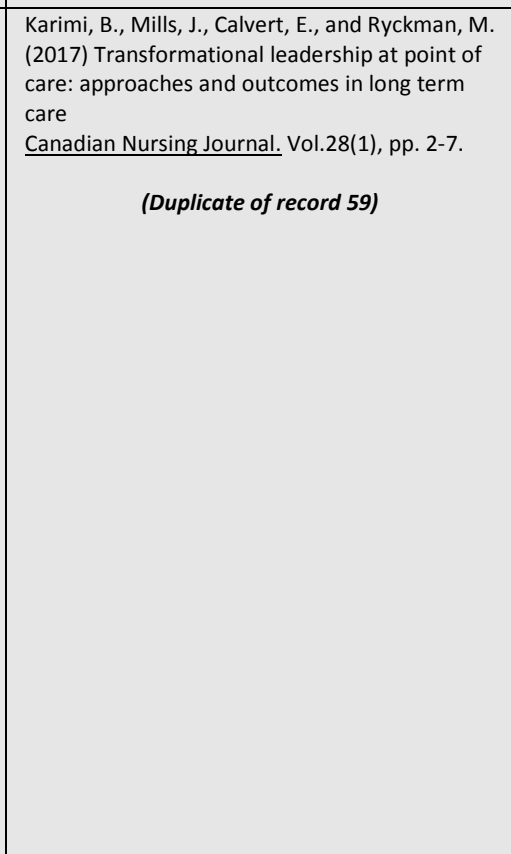 & Research & $\begin{array}{l}\text { Canada } \\
\text { Long term care }\end{array}$ & 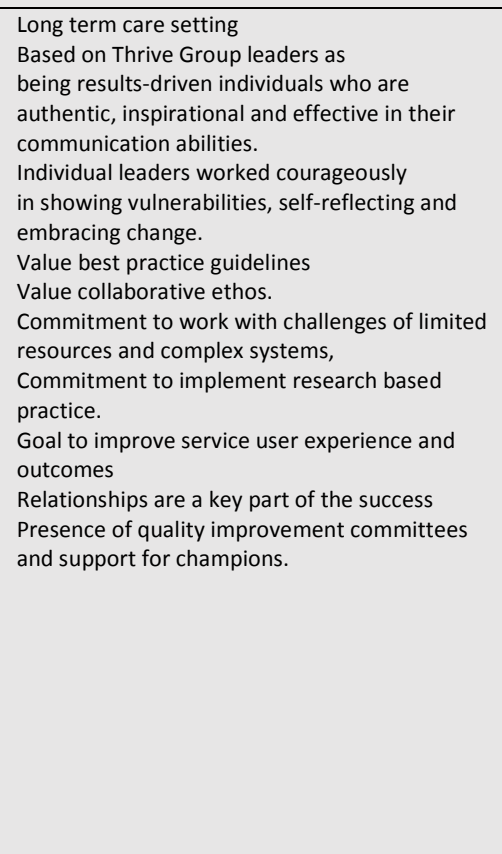 & 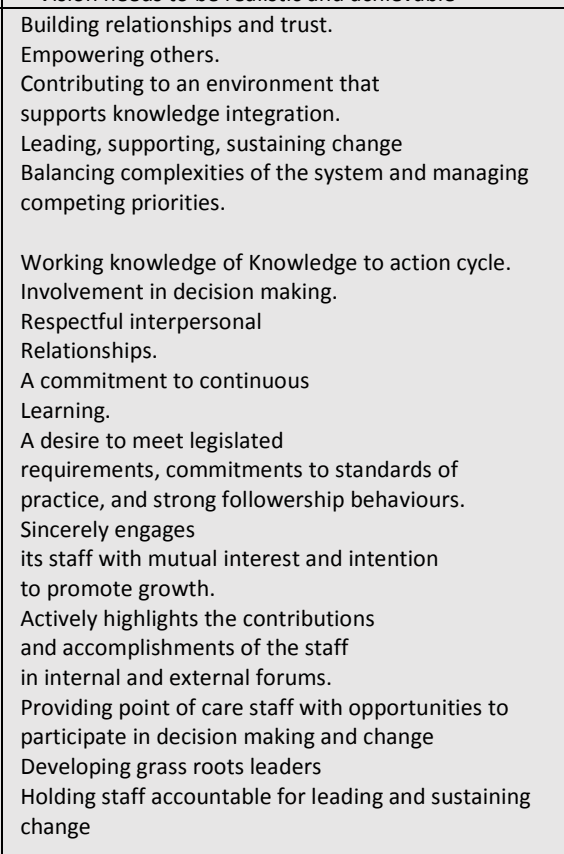 & 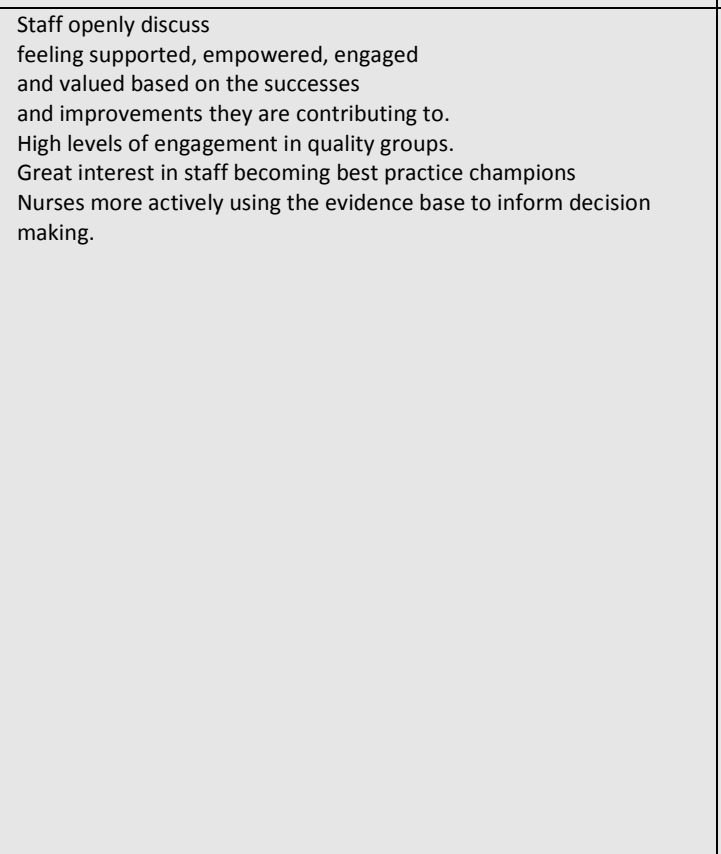 & $\begin{array}{l}\text { Staff - Unit was designated Great } \\
\text { places to work following } \\
\text { implementation of leadership } \\
\text { programme. }\end{array}$ & 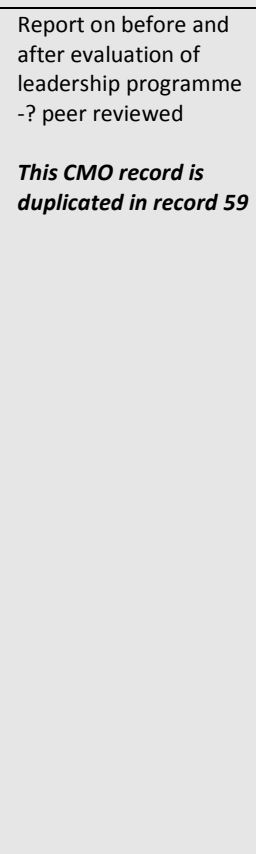 \\
\hline $\begin{array}{l}5 / \\
58 \\
59 \\
60\end{array}$ & 57 & 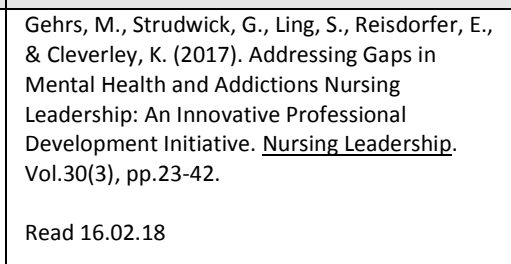 & Describing initiative & $\begin{array}{l}\text { Mental health and addictions } \\
\text { services in Toronto, Canada }\end{array}$ & $\begin{array}{l}\text { - Difficulty recruiting mental health \& } \\
\text { addictions nurse leaders with experience } \\
\text { - Practice development } \\
\text { - Implementing eductional programme } \\
\text { focusing on leadership } \\
\text { - Initititive in } 5 \text { th year of } 10 \text { year programme. }\end{array}$ & 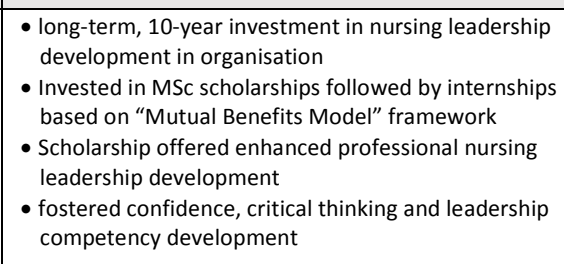 & $\begin{array}{l}\text { Initiative provided mentees with: } \\
\text { - Improved understanding of the Clinical Nurse Specialist role. } \\
\text { - Opportunity to observe and then mirror leadership styles. } \\
\text { - Provided a safe space to receive feedback and improve eadership pr. } \\
\text { - Meeting their career goals, increasing their confidence level and } \\
\text { helping them learn more about leadership stylles. } \\
\text { - Inititivive increased visibility and credibility of nursing profession } \\
\text { within organization. }\end{array}$ & $\begin{array}{l}\text { - Nurse leaders } \\
\text { Nursing profession } \\
\end{array}$ & $\begin{array}{l}\text { Mutual benefits } \\
\text { Model" framework }\end{array}$ \\
\hline
\end{tabular}


Individualized Role Development Plans align to
organizational leadership competency needs, intern interests \& mentor expertise.

time in supporting mentees. - Mentees invested effort in accepting guidance \& coaching from mentors.
Mentes engaged in actities to further develop
their informal leadership skills and participate in

Shared vision:

- helped leaders and teams to become inspired and

commintted to a shared goal
strong driving force for practice development

strong tool for successful transformation of practice
importance of having shared values and defined goals
- leaders steered practice development more

- Leaders steered practice development more
systematically and efficiently if they employed

strategic goals through a shared vision.
- Leaders and team members experienced that shared visions provided clear orientation and a strong purpose in practice.
- positive impact of
Sh

deal of enthusiasm, which had potential to overload
the organisation through hat pon more than could through tak

to focus their energies and 作 政 innovation/transformation and relaxation/recovery
- The empowerment of team members is key for to The empowerment of team members is key for to
transform the cutture of care into that of an
and change

- Leader can only create the vision in a top down approach with a small selection of staff members, so
the integration of the entire team remained a huge - Initiative guided by 'Point-of-Care Leadership Tips
and Tools for Nurses' based on the 'Healthy Work and Tools for Nurses' based on the 'Healthy Work
Environment Best Practice Guidelines: Developin and Sustaining Nursing Leadership'. - Implemented 5 Transformational Leadership
practice recommendations for point of-care leaders . Buld ding relationships
2 mpowering others. Contributing to an environment that supports 4. Leading, supporting, sustaining change

\section{Programme covered: Benners novice to expert
model, Carper's four ways of knowing, Critical} model, Carper's four ways of knowing,
thinking, Leadership stylys, Roles and

responsibilitites Leading to success, Empowerment,
Change strategies, Tream building skills, Effective milies, Communication, engagement, steward and stakeholder and finally Project management
niteractive learning approach including reflective and critical analysis.
Use of action research in simulated case studies - The evidence-based Nurse Practitioner framework
(HNPP) provides arenewed vision for
understanding what is unique about the NP role and anderstanding what is unique about the
how to acquire full role value. (Hurlock-ch 2013; Hurlock-Chorosteckie te tal. 2014 -14 - Author suggests hospital leaders and physicians play
major role in the success of reaching full NP role

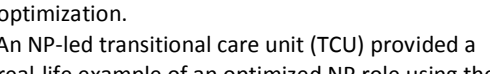
real-ifife example of a a optimized NP role using the -NP main person responsible for patient care
decisions with part-time physician support - Employees do a "caring reflection" of practice based Daily caring check-ins (huddlles)
- Staff learn to be still for 2 minutes, to center, pause Initiative:
- provided guidance on infrastructures to put in place

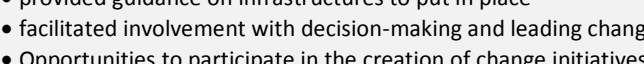
- Opportunities to participate in the creation of change initititives
- Participation in decision-making processes used to gain trust and commitment to strategic directions of organizal
- Providing staff with support, resources, tools - Holding staff accountable for leading and sustaining change
- increased engagement and commitment to culture of quality - More able to identify skills of an effective clinical leader leadership knowledge and stakeholder engagement - Improved self-awareness and critical thinking through engaging in
self-reflection activities

\section{Implementation of NP in one hospital led to} - Broad systems cost savings being realized
- Easy access to the NP on the TCU allowed for rapid and early - Easy access to the NP on the TCU allowed for rapid a
intervention in situations of patient deterioration
- Emergency room avoidance became more common

and reflect.

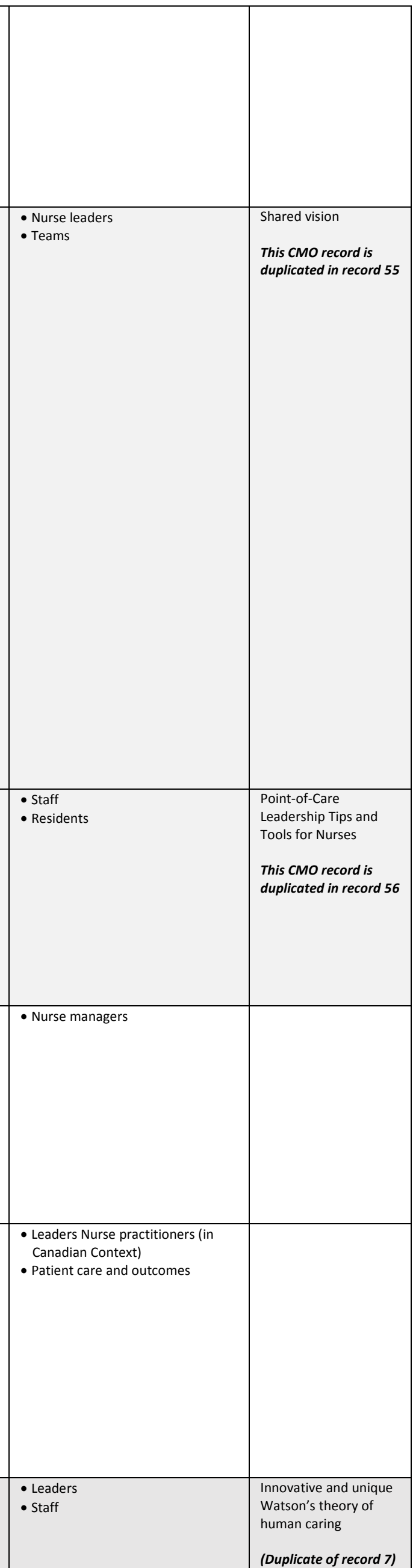




\begin{tabular}{|c|c|c|c|}
\hline 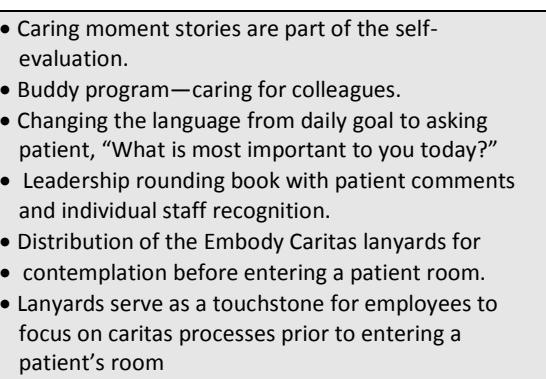 & & & \\
\hline 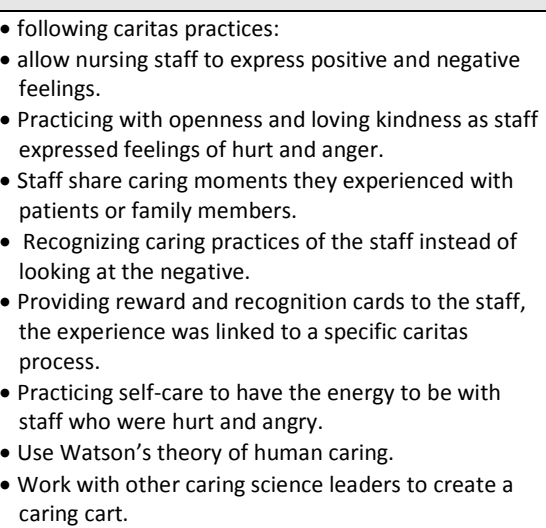 & $\begin{array}{l}\text { - provided an opportunity for staff to become familiar with the } \\
\text { language of caring while providing tangible examples of how } \\
\text { caring is expressed in practice }\end{array}$ & • staff & \\
\hline 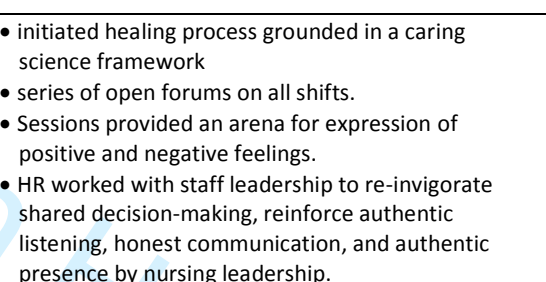 & $\begin{array}{l}\text { - Eduction related to Watson's theory of human caring provided a } \\
\text { renewed sense of hope and reminded hurses of the importance of } \\
\text { practicing from the heart and not from anger }\end{array}$ & - Staff & \\
\hline 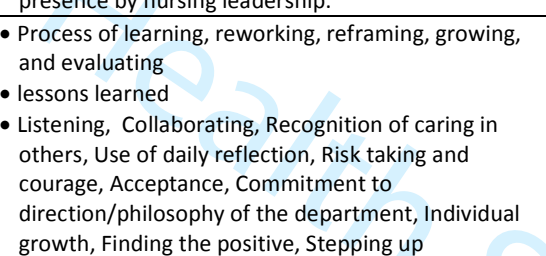 & 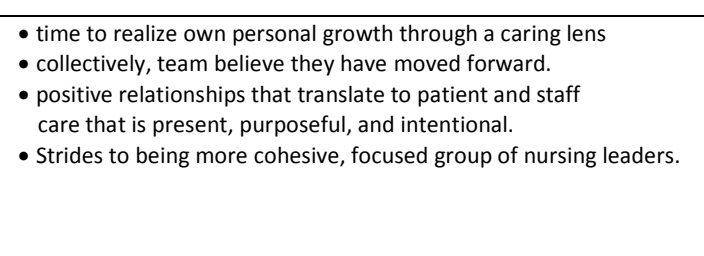 & \begin{tabular}{|l|l} 
- Patients \\
- Staff
\end{tabular} & \\
\hline 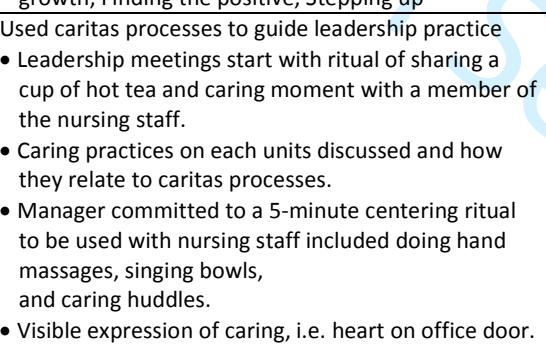 & $\begin{array}{l}\text { - Managers use 5-item Watson Caritas Assessment Score as a way } \\
\text { for nursining staff to formally vevaluate nurse manager caring } \\
\text { behaviours. }\end{array}$ & - Staff & $\begin{array}{l}\text { Watson's theory of } \\
\text { human caring }\end{array}$ \\
\hline $\begin{array}{l}\text { - realisising commitment, negotitating conditions and } \\
\text { encouragement to keep momentum going can } \\
\text { supportr implementation of change } \\
\text { - giving voice to the staff identified as enabling factor } \\
\text { for reeping momentum going. } \\
\text { - communication crucial between all involved. } \\
\text { - suppoptrive role modellilig by managerial leader } \\
\text { - change oriented behaviour by management such as } \\
\text { "providing vision and direction }\end{array}$ & $\begin{array}{l}\text { - continuuus reciprocal relationship between managerial leaders } \\
\text { and clinical leaders key to successful implementatiotion }\end{array}$ & - staff & "building of a bridge" \\
\hline 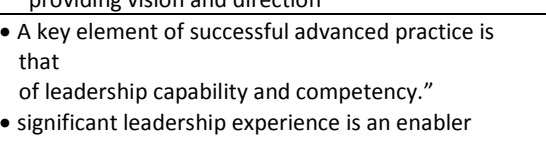 & $\begin{array}{l}\text { - Advanced practitioner roles or positions would benefit } \\
\text { dietitians }\end{array}$ & - dietitians & \\
\hline 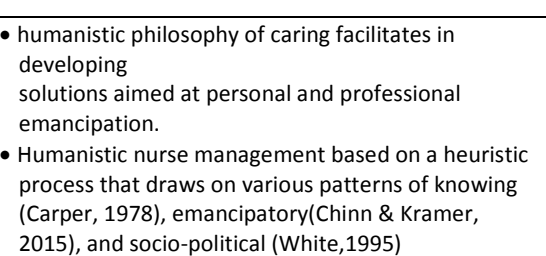 & 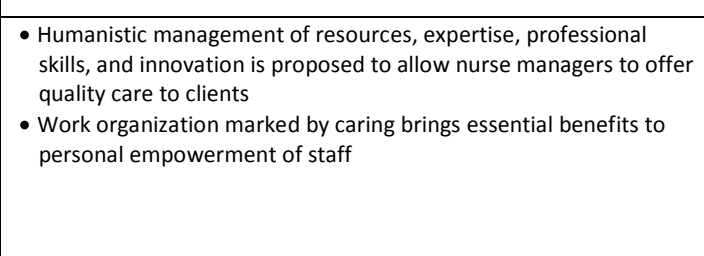 & $\begin{array}{ll}\text { staff } \\
\text { patients }\end{array}$ & $\begin{array}{l}\begin{array}{l}\text { Phillosophy of } \\
\text { humanism }\end{array}\end{array}$ \\
\hline
\end{tabular}




\begin{tabular}{|c|c|c|c|c|c|c|c|c|}
\hline 70 & 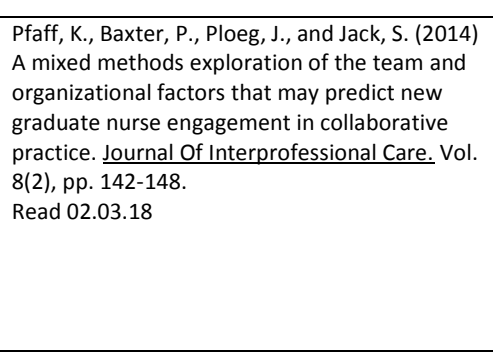 & Journal Article research & $\begin{array}{l}\text { Newly qualified nurses in } \\
\text { Canada completed the } \\
\text { Collaborative Practice } \\
\text { Assessment Tool. }\end{array}$ & $\begin{array}{l}\text { - studdy explored team and organizational } \\
\text { factors that may predict rewly zualified nurse } \\
\text { engagement in collaborative practice. }\end{array}$ & 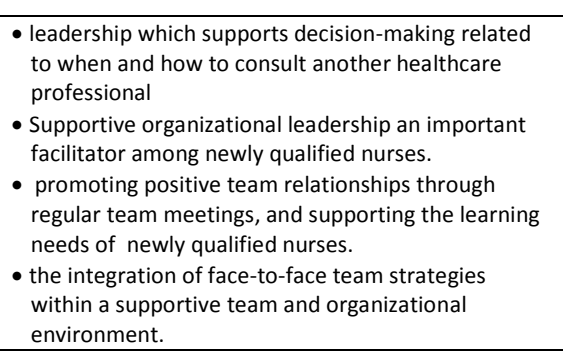 & $\begin{array}{l}- \text { Studd concludes priritity given to strategies that promote } \\
\text { accessible leadership, yuality preceptorship and mentorship } \\
\text { models for newly qualified nurses. }\end{array}$ & • newly qualified nurse & \\
\hline 71 & 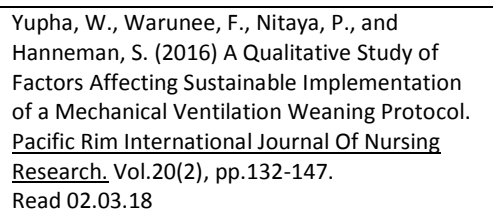 & Journal Article research & ICU department in Thailand & $\begin{array}{l}\text { - A Qualitative study focusing on sustainable } \\
\text { Implementation mechanical ventilation } \\
\text { weaning protococo (MVWP) }\end{array}$ & $\begin{array}{l}\text { - Leadership encouragement including broad staff- } \\
\text { assistive } \\
\text { activities of educting, consulting, and coaching, } \\
\text { role modellign, } \\
\text { and monitoring implementation of practice. } \\
\text { - leadership monitoring and audith helps to odentify } \\
\text { gaps in implementation for quality improvement. }\end{array}$ & $\begin{array}{l}\text { - Study concludes continuing education important strategy to } \\
\text { improve staff attitude and competence. }\end{array}$ & - Nursing staff & \\
\hline 73 & $\begin{array}{l}\text { Fynes, E., Martin, D., Hoy, L., and Cousley, A. } \\
\text { (2014) Anaesthetic nurse specialist role: } \\
\text { leading and facilitation in ilinicac practice, } \\
\text { Journal Of Perioperative Practice. Vol.24(5) pp. } \\
97-102 .\end{array}$ & Journal Article - review & Literature review & $\begin{array}{l}\text { Article provided overview of leadership, } \\
\text { followed by disisussion on nits applicability to } \\
\text { Alaesthetic nurse specialist role }\end{array}$ & $\begin{array}{l}\text { - Building trust, demonstrating integrity inspiring, } \\
\text { encouraging and coaching others led to positive } \\
\text { working environment } \\
\text { - sole use of transformational skills may not be } \\
\text { enough to ensure effectiveness unless combined } \\
\text { with some components of transactional leadership } \\
\text { itself e.g. rewarding achievenents and monitoring } \\
\text { mistakes }\end{array}$ & 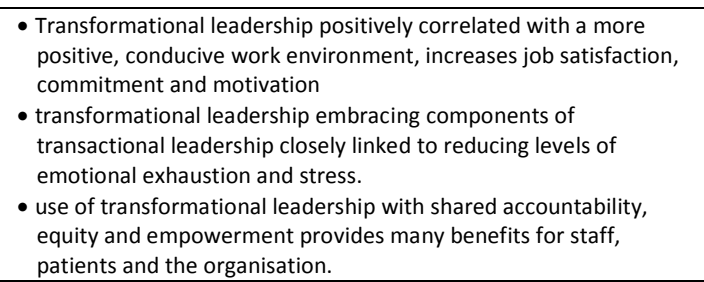 & $\begin{array}{l}\text { - Staff } \\
\text { : Patients } \\
\cdot \text { Organisations }\end{array}$ & \\
\hline 74 & $\begin{array}{l}\text { Bobbio, A., and Manganelli, A. (2015) } \\
\text { Antecedents of hospitial nurses' 'intention to } \\
\text { leave the organization: A cross sectional } \\
\text { survey, International Juorual Of Nursing } \\
\text { Studies, Vol.52 (7), pp.1180-1192. } \\
\text { Read 02.03.18 }\end{array}$ & journal article - research & Hospitals withii Italy & $\begin{array}{l}\text { - Servant Leadership Survey utilised } \\
-711 \text { Cross sectional surveys sompleted within } \\
\text { two Italian public general hospitals }\end{array}$ & 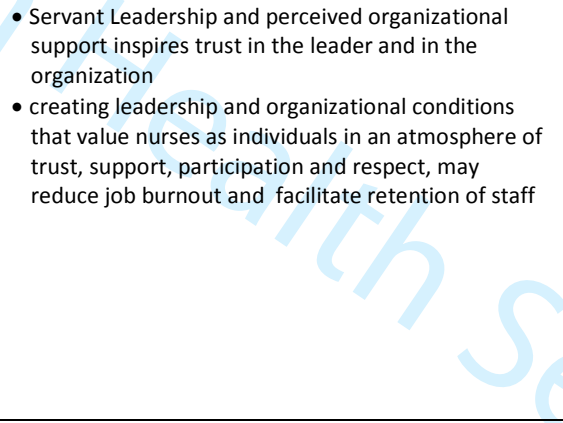 & $\begin{array}{l}\text { - Servant Leadership may reduce burnout in staff and facilitate } \\
\text { retention of staff }\end{array}$ & $\begin{array}{l}\text { : Staff } \\
\text { Organisation }\end{array}$ & 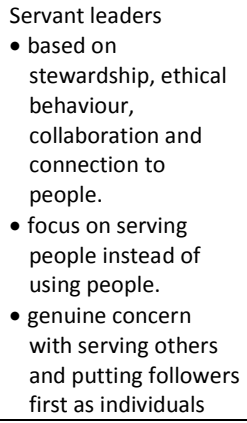 \\
\hline 75 & $\begin{array}{l}\text { Hansen, I. (2011) Be a change leader. Standard. } \\
\text { Vol. 36(1), pp. 10-12. } \\
\text { Read 02.03.18 }\end{array}$ & Journal Article - pictorial & $\begin{array}{l}\text { Rehabilitation Centre in } \\
\text { Ontario, Canada }\end{array}$ & Implementing a change in practice & 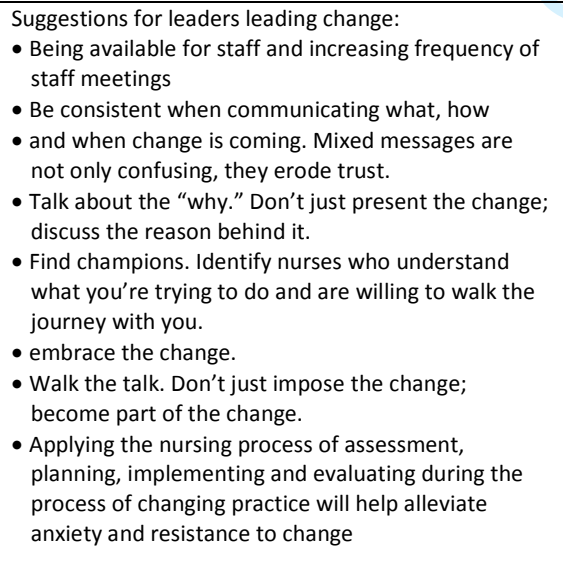 & $\begin{array}{l}\text { - With understanding comes acceptance, which makes it easier to } \\
\text { apply new knowledge or skills to make change successful }\end{array}$ & $\begin{array}{l}\text { Staff } \\
\text { - Patients } \\
\text {-Organisation }\end{array}$ & \\
\hline
\end{tabular}




\begin{tabular}{|c|c|c|c|c|c|c|c|c|c|}
\hline $1_{1}^{\text {No }}$ & & Reference & tegory & & ntext & Mechanisms & Outcomes & Impact on whom & Notes \\
\hline $\begin{array}{l}3 \\
4 \\
5 \\
6 \\
7 \\
8 \\
9 \\
10 \\
11 \\
12 \\
13 \\
14 \\
15 \\
16 \\
17 \\
18 \\
19 \\
20 \\
21 \\
22 \\
23 \\
24 \\
25 \\
26 \\
27 \\
28 \\
29 \\
30 \\
31 \\
32 \\
33 \\
34 \\
35 \\
36 \\
37\end{array}$ & & & & 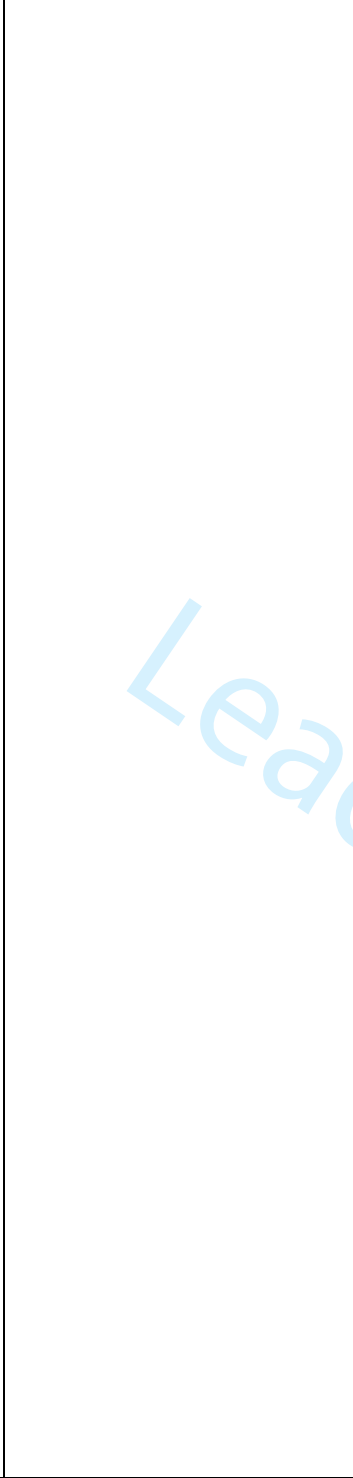 & & 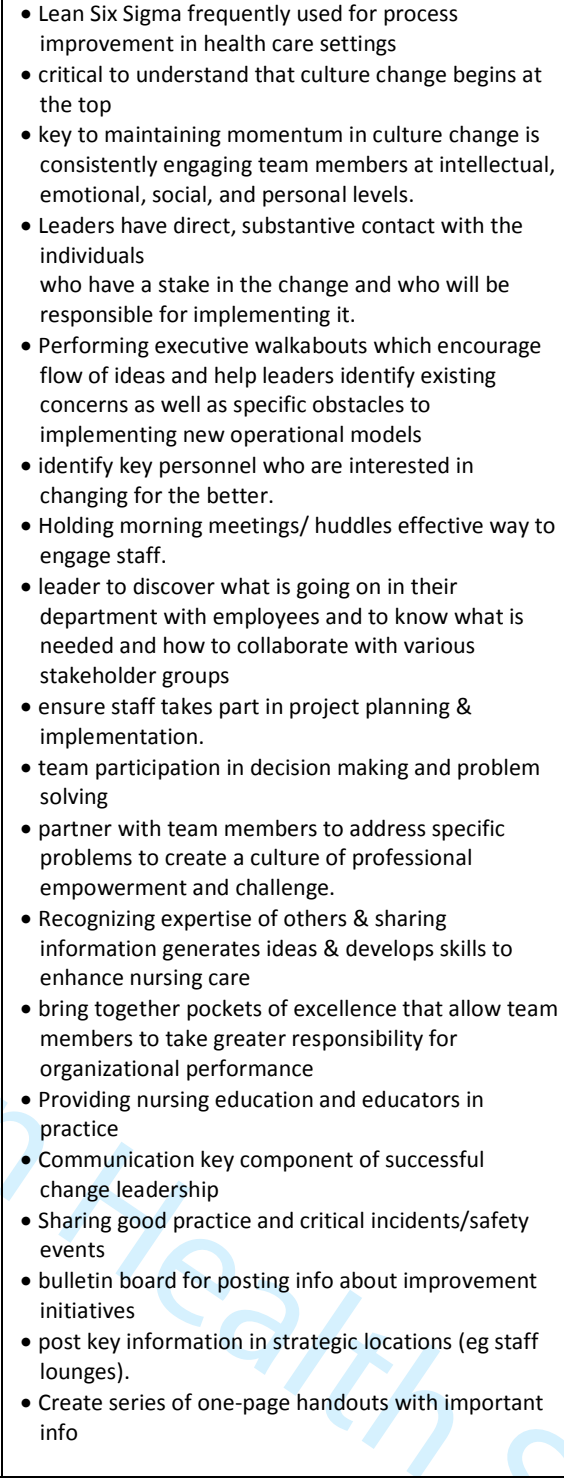 & & & $\begin{array}{l}\text { create standardized } \\
\text { workflow practices. }\end{array}$ \\
\hline $\begin{array}{l}38 \\
39 \\
40 \\
41 \\
42 \\
43 \\
44 \\
45 \\
46 \\
47 \\
48 \\
49\end{array}$ & 77 & 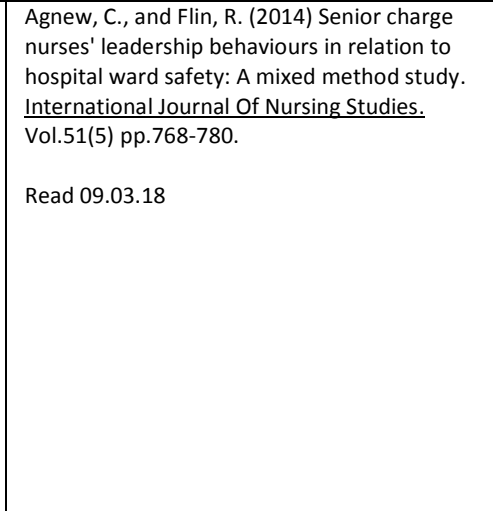 & \begin{tabular}{|l|} 
journal article - research, \\
\end{tabular} & hospital ward context. & 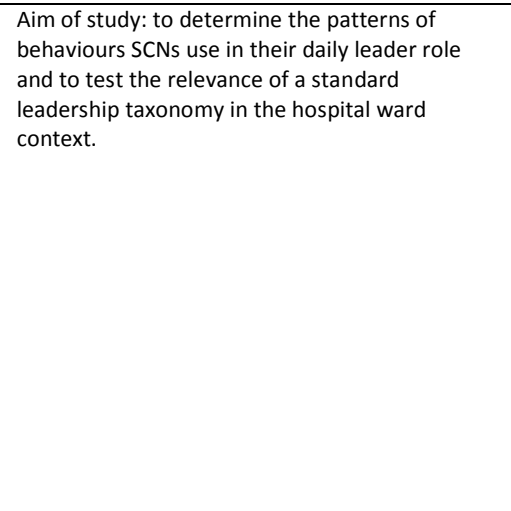 & 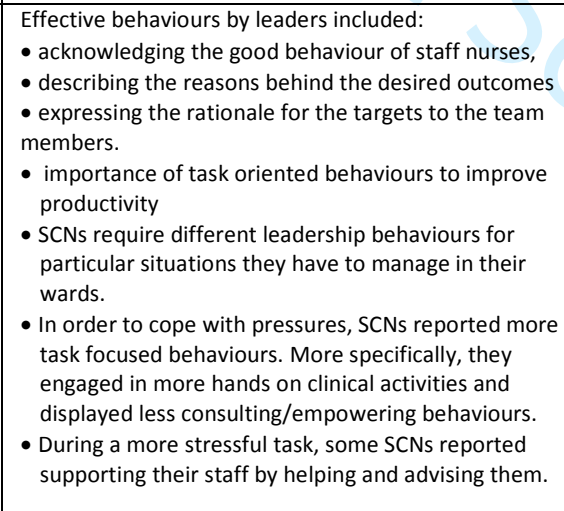 & 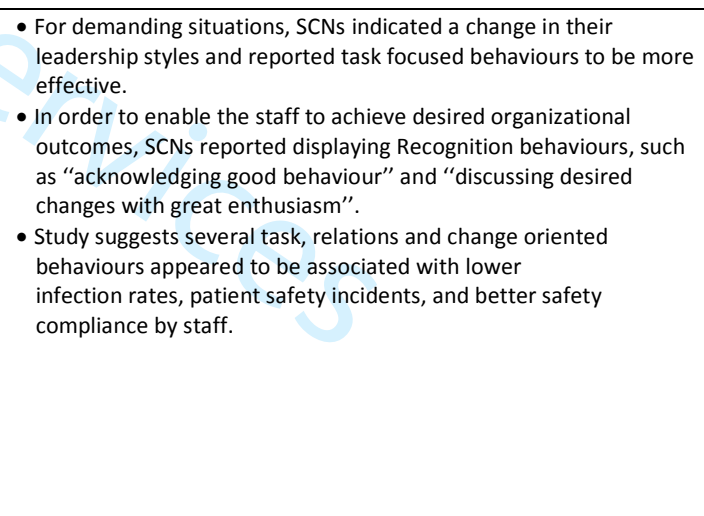 & 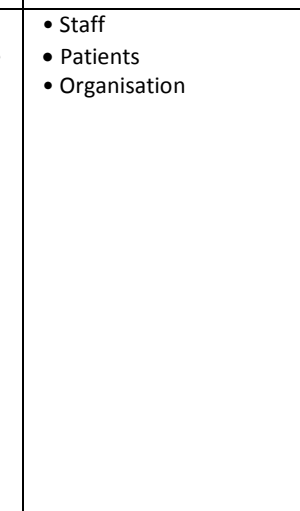 & \\
\hline $\begin{array}{l}50 \\
51 \\
52 \\
53 \\
54 \\
55 \\
56 \\
57\end{array}$ & 78 & 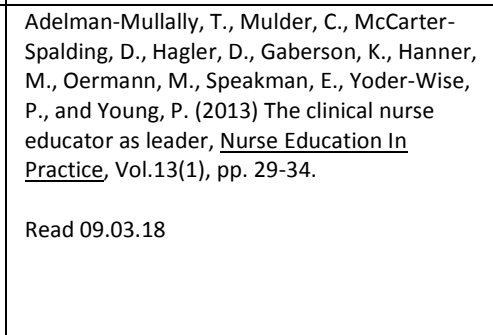 & \begin{tabular}{|l} 
Literature review and \\
yearlong discussions on \\
leadership
\end{tabular} & $\begin{array}{l}\text { - Nurse Education } \\
\text { - Clinical nurse educator as } \\
\text { leader }\end{array}$ & 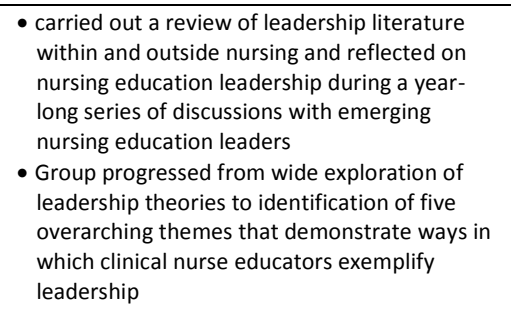 & $\begin{array}{l}\text { - clinical nurse educators exemplify leadership by: } \\
\text { role modelling, providing vision, helping students to } \\
\text { learn, challenging the system or status quo, and } \\
\text { seeking relational integrity }\end{array}$ & $\begin{array}{l}\text { - Suggesst leadership potential of clinical nurse educators to help } \\
\text { transform nursing education through meaningful interactions with } \\
\text { students. }\end{array}$ & - Nursing students & \\
\hline $\begin{array}{l}58 \\
59 \\
60\end{array}$ & 79 & 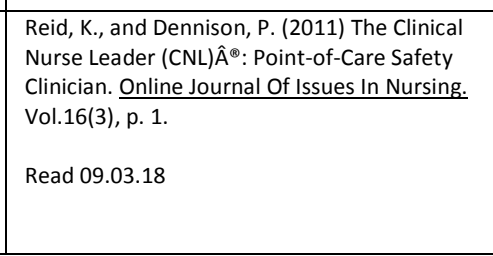 & \begin{tabular}{|l|l} 
Journal article - discussion \\
\end{tabular} & \begin{tabular}{|l|} 
- Clinical nurse leaders (CNL) \\
working in hospital \\
environments within America
\end{tabular} & $\begin{array}{l}\text { - discussion and vevaluation of the role of clinical } \\
\text { nurse leaders within hospital environments }\end{array}$ & 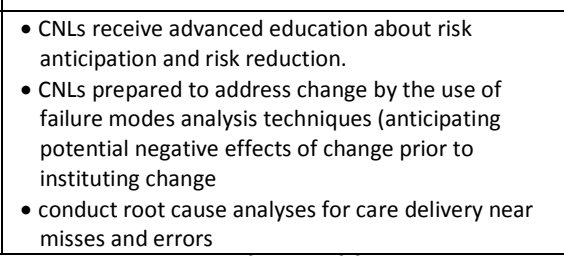 & 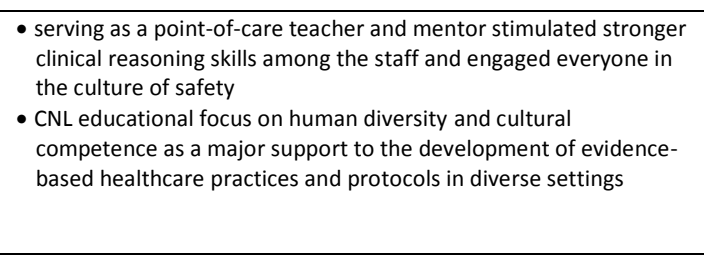 & - Nursing teams & $\begin{array}{l}\text { Appreciative based } \\
\text { approach }\end{array}$ \\
\hline
\end{tabular}




\begin{tabular}{|c|c|c|c|c|c|c|c|c|}
\hline & & & & & 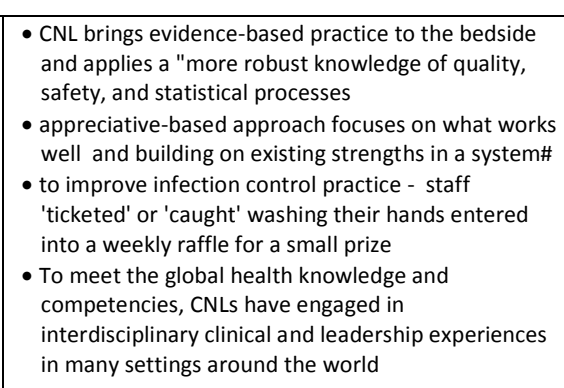 & & & \\
\hline 80 & 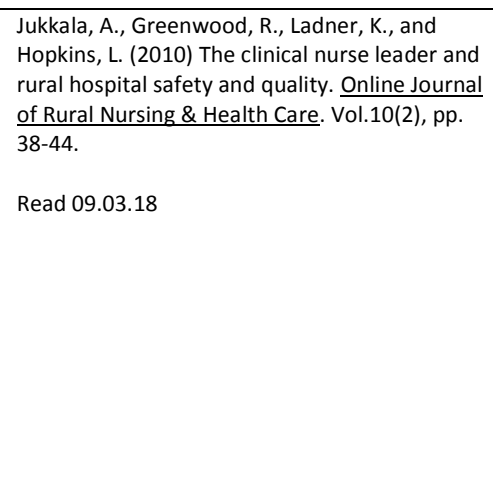 & Journal Article & $\begin{array}{l}\text { Rural healthcare system in } \\
\text { America }\end{array}$ & $\begin{array}{l}\text { Discussion on the role of CNIs in rural healthcare } \\
\text { system in America }\end{array}$ & 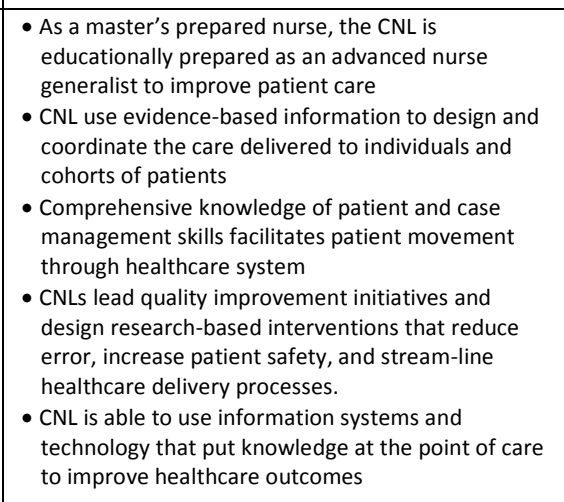 & Focused on processes and qualities rather than outcomes. & $\begin{array}{l}\cdot \text { - Patients } \\
\text { - Staff }\end{array}$ & \\
\hline 81 & $\begin{array}{l}\text { Stavrianopoulos, T. (2012) The clinical nurse } \\
\text { leader. Health Science Juurnal. Vol.6(3), pp. } \\
\text { 392-401. } \\
\text { Read 09.03.18 }\end{array}$ & $\begin{array}{l}\text { Literature reviews on the } \\
\text { role of the Clinical nurse } \\
\text { leader }\end{array}$ & $\begin{array}{l}\text { Literature review regarding the } \\
\text { Clinical nurse leader role (CNL) }\end{array}$ & $\begin{array}{l}\text { Clinical nurse leader role is repared in a new } \\
\text { master of nursing curriculum that educates } \\
\text { nurrses to understand how to provide care and } \\
\text { improve quality in today's complex healthcare } \\
\text { system. }\end{array}$ & 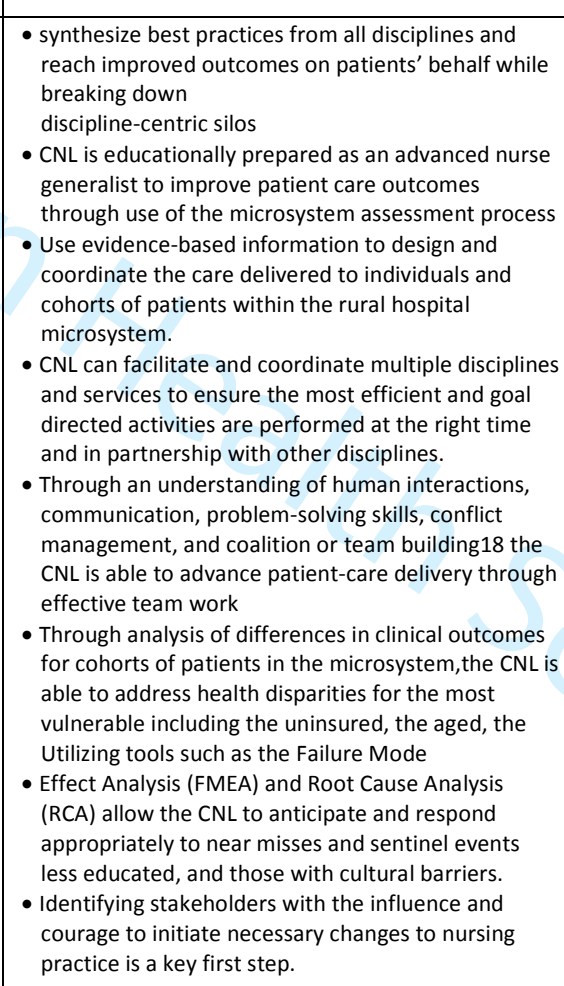 & 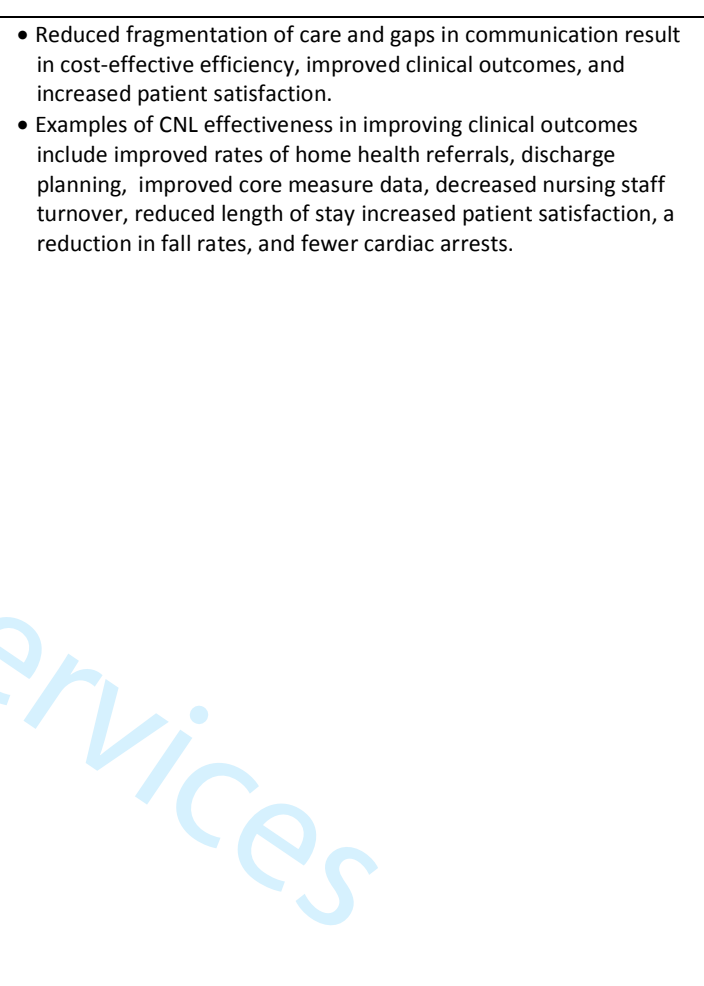 & $\begin{array}{l}\text { Patients } \\
\text { - Staff } \\
\text { - Organisation }\end{array}$ & $\begin{array}{l}\text { The Clinical Nurse } \\
\text { Leader role developed } \\
\text { in response to } \\
\text { concerns about quality } \\
\text { and } \\
\text { safety of nursing care } \\
\text { in the complex, } \\
\text { technologically } \\
\text { advanced, ever- } \\
\text { changing healthcare } \\
\text { system }\end{array}$ \\
\hline 82 & 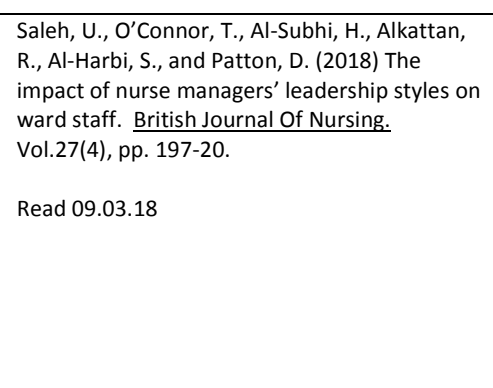 & Journal article - research & $\begin{array}{l}\text { Phenomenological study - } 35 \\
\text { nurses working in nifferent } \\
\text { specialties of a medical city in } \\
\text { Saudi Arabia. }\end{array}$ & & $\begin{array}{l}\text { - participants described four types of leadership } \\
\text { sttles: relational leadership, preferential leadership, } \\
\text { communication chain leadership, and ineffectual } \\
\text { leadership } \\
\text { - relationship between ward nurses and their } \\
\text { management team is a determinant of job } \\
\text { satisfaction }\end{array}$ & 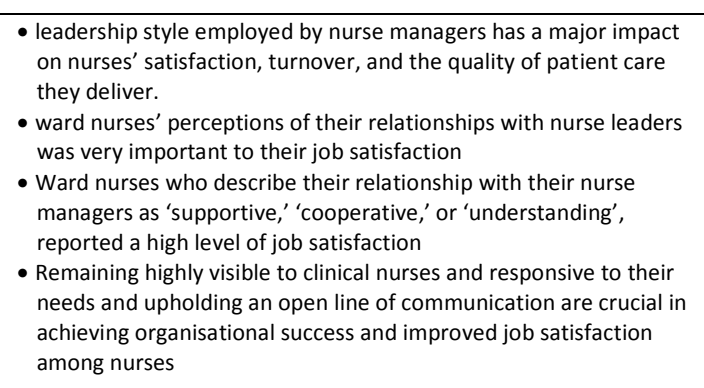 & $\cdot$ - Staff & \\
\hline 83 & 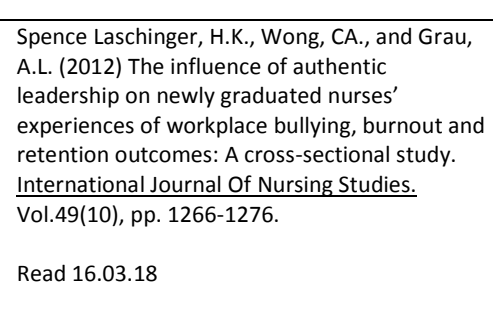 & Journal article research & $\begin{array}{l}\text { new graduate nurses working } \\
\text { in acutu care } \\
\text { hospitals in Ontario, Canada. }\end{array}$ & 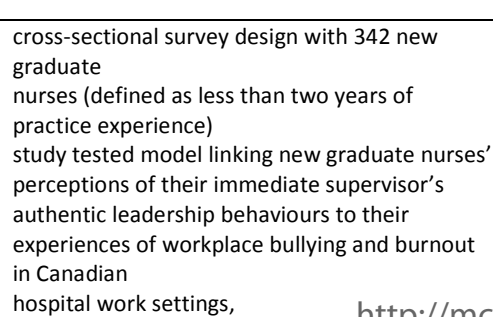 & $\begin{array}{l}\text { leadership practices that promote a supportive work } \\
\text { climate by discouraging negative interpersonal } \\
\text { interactions play an important role in retaining } \\
\text { newly graduated nurses. }\end{array}$ & $\begin{array}{l}\text { - authentic leadership practices promote healthy workplace } \\
\text { conditions that positively yinfluence factors that encourage new } \\
\text { graduate nurse retention. }\end{array}$ & staff & \\
\hline
\end{tabular}




\begin{tabular}{|c|c|c|c|c|c|c|c|c|c|}
\hline \multicolumn{10}{|c|}{ Impact on whom } \\
\hline $\begin{array}{l}10 \\
11 \\
12 \\
13 \\
11\end{array}$ & 84 & 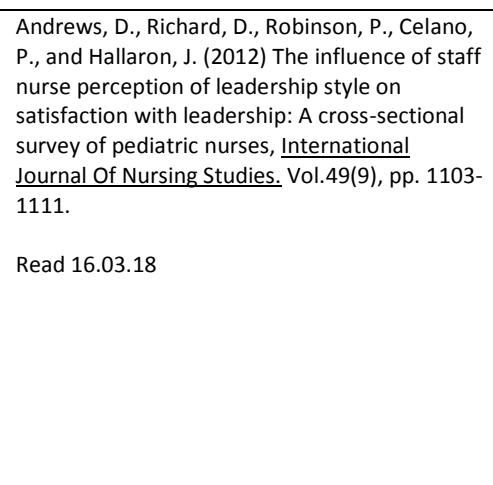 & Journal article research & $\begin{array}{l}\text { Range of clinical areas. All } \\
\text { authors from Florida - research } \\
\text { possibly completed in Florida. }\end{array}$ & $\begin{array}{l}16 \text { supervisors and } 179 \text { supervisees completed } \\
\text { the Multifactor Leadership Questionnaire and a } \\
\text { demographic survey }\end{array}$ & 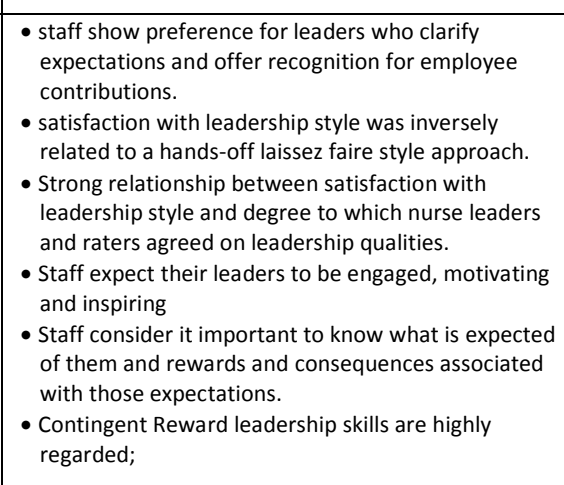 & 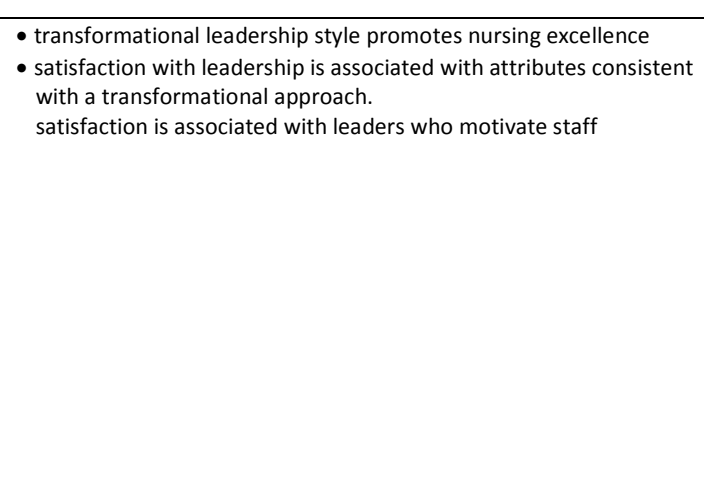 & $\cdot$ - staff & \\
\hline $\begin{array}{l}15 \\
15 \\
16 \\
17 \\
18 \\
19 \\
20 \\
21\end{array}$ & 85 & 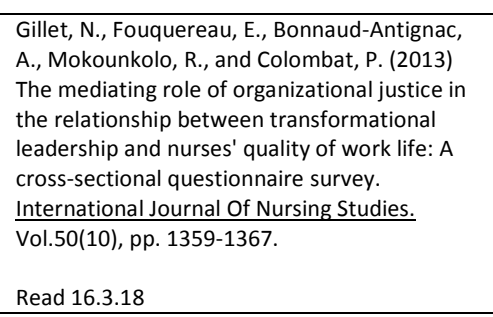 & Journal article research & $\begin{array}{l}\text { Study took place in } 47 \text { different } \\
\text { haematology, oncology, and } \\
\text { haematology/ } \\
\text { oncology nuits in France. } \\
\text { Participants were nurses and } \\
\text { auxiliary nurses. }\end{array}$ & 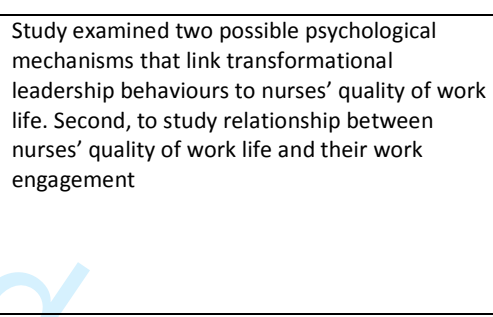 & $\begin{array}{l}\text { - organizational justice an important psychological } \\
\text { mechanism in the relationship between supervisors' } \\
\text { leadership style and nurses' quality of work life. }\end{array}$ & 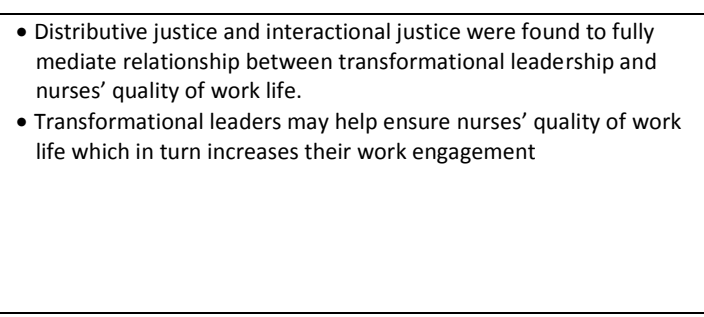 & - Organisation & \\
\hline $\begin{array}{l}22 \\
23 \\
24 \\
25 \\
26 \\
27 \\
28 \\
29 \\
30 \\
31 \\
32 \\
33 \\
34 \\
35 \\
36 \\
37 \\
38 \\
39 \\
40 \\
41 \\
42 \\
43 \\
44 \\
45 \\
46 \\
47 \\
48 \\
49 \\
50 \\
51 \\
52 \\
53 \\
54 \\
55 \\
56 \\
57 \\
58 \\
59 \\
60\end{array}$ & 86 & $\begin{array}{l}\text { Schwartz, D., Spencer, T., Wilison, B., and } \\
\text { Wood, K. (2011) Transformational leadership: } \\
\text { implictions for nursing leadedrs in facitities } \\
\text { seeking magnet designation. AORN Journal. } \\
\text { Vol.93(6) p. p.7377-748. } \\
\text { Read 16.3.18 }\end{array}$ & Journal article - research & $\begin{array}{l}\text { Leaders, staff members, and } \\
\text { educators in a } \\
\text { two-hospital system in Virginia, } \\
\text { USA }\end{array}$ & 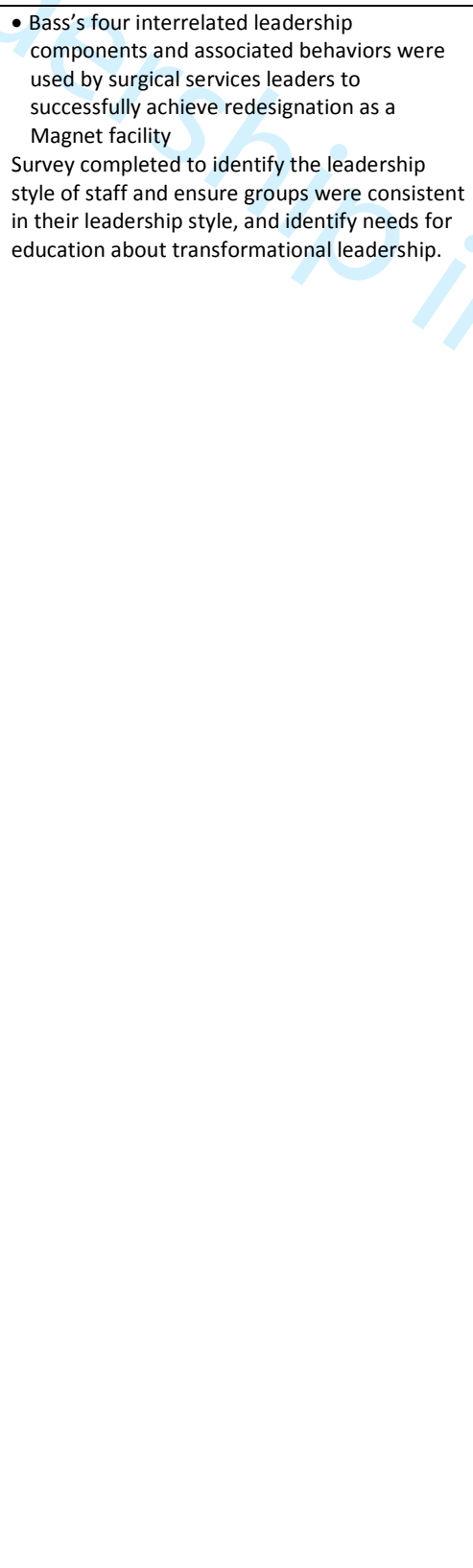 & 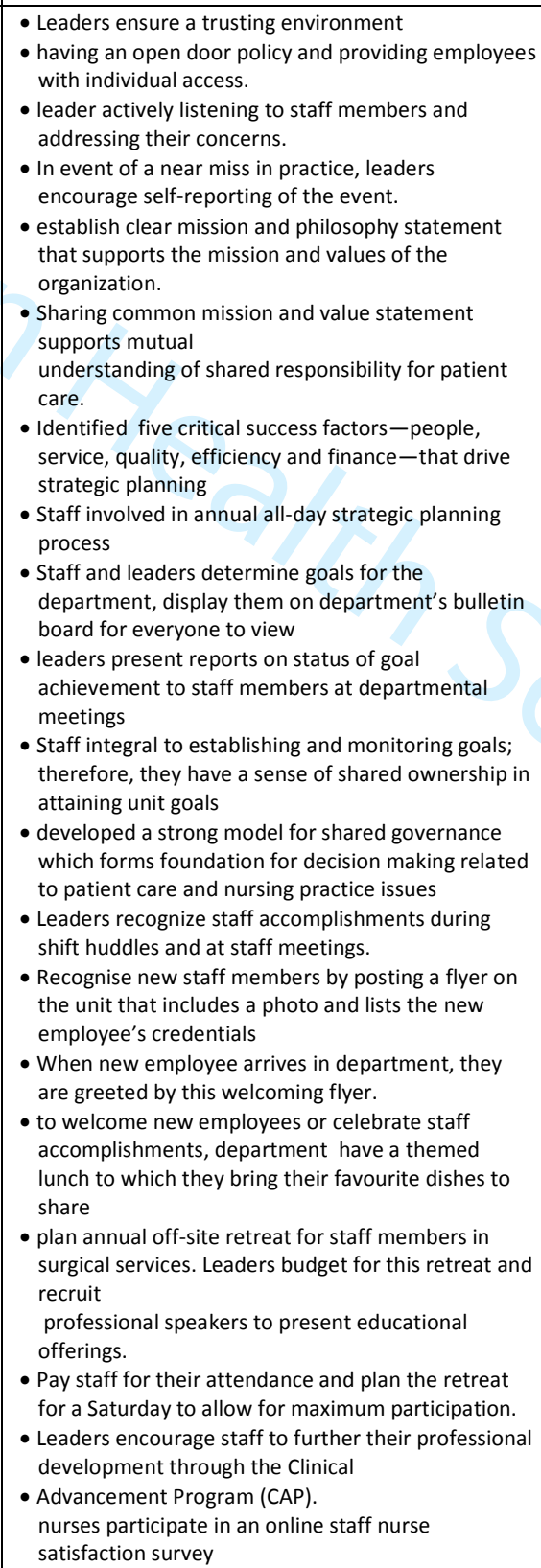 & 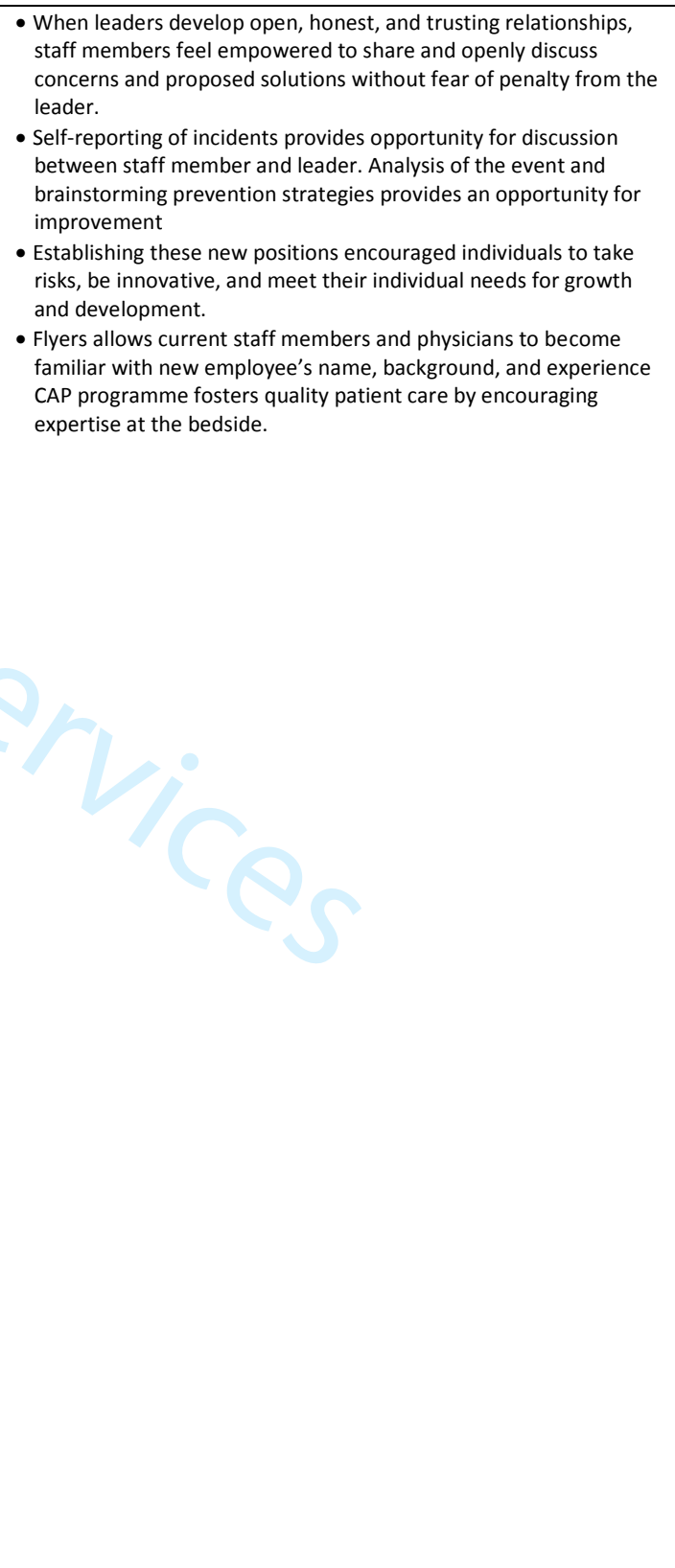 & 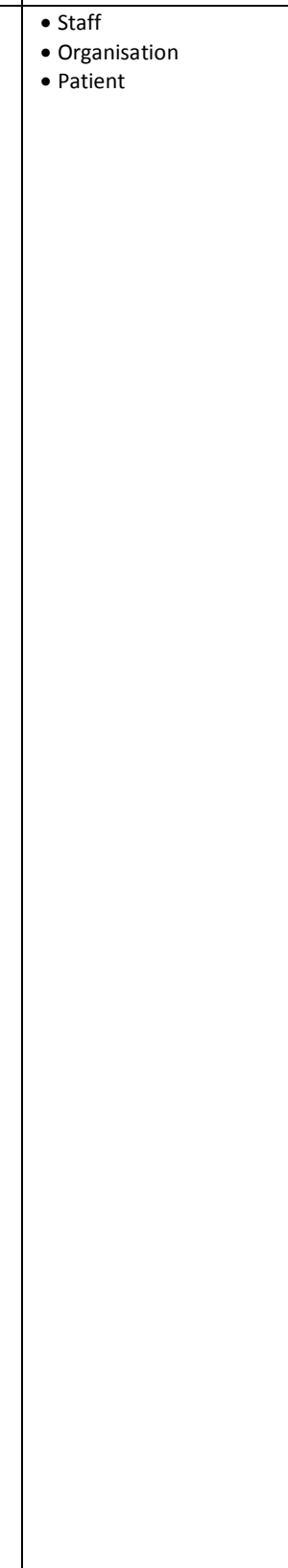 & 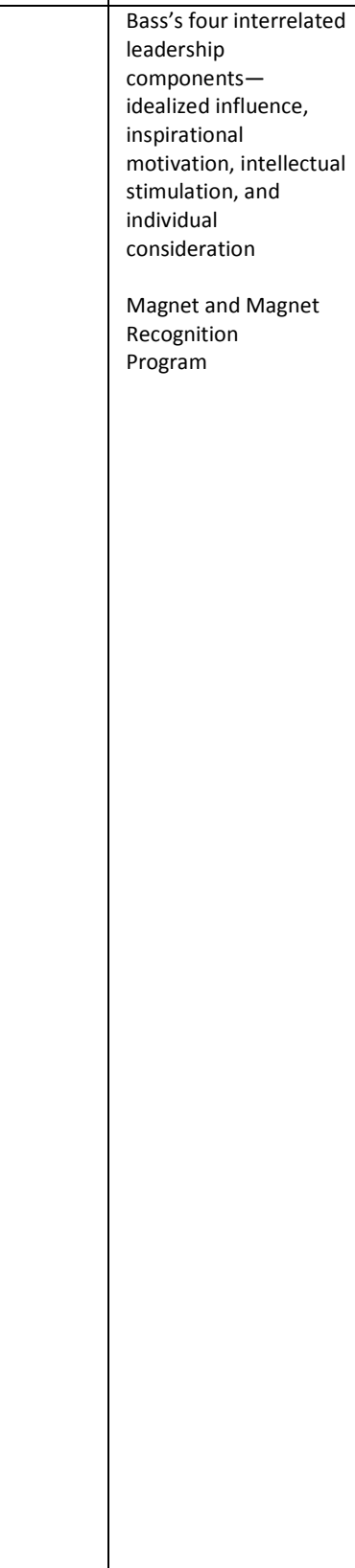 \\
\hline & 87 & 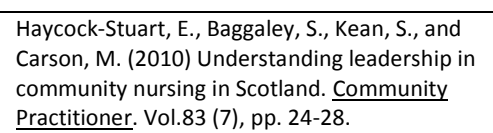 & Journal article - research & $\begin{array}{l}\text { Study in three health boards in } \\
\text { Scotland with district nurses } \\
\text { and health visitors }\end{array}$ & $\begin{array}{l}\text { - paper reports findings of a research study that } \\
\text { aimed to tidentify how leadershipi is serceived } \\
\text { and experienced by community nurses } \\
\text { http: } / / \mathrm{mc}\end{array}$ & 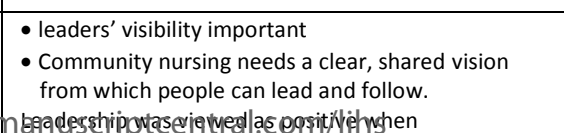 & $\begin{array}{l}\text { - strong leadership can help address invisibilility of community } \\
\text { nursing work }\end{array}$ & $\begin{array}{l}\cdot \text { Staff } \\
:^{\text {Organisation }}\end{array}$ & \\
\hline
\end{tabular}




\begin{tabular}{|c|c|c|c|}
\hline $\begin{array}{l}\text { - leaders listened } \\
\text { - consulted before implementing changes, } \\
\text { - respected and valued the contributions staff were } \\
\text { making to } \\
\text { - community nursing, } \\
\text { explained why things were changing, } \\
\text { - had an understanding of different policy agendas } \\
\text { - motivated staff to develop the service with them. }\end{array}$ & & & \\
\hline 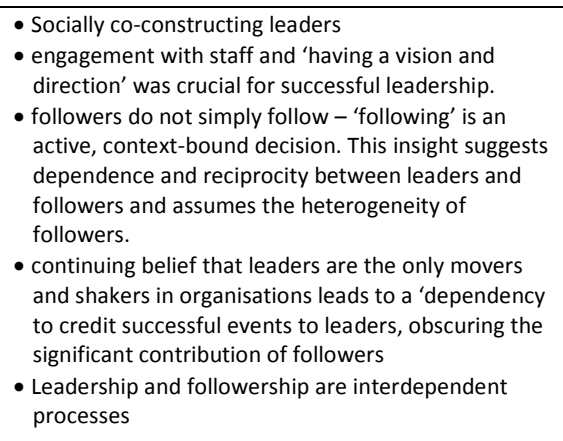 & $\begin{array}{l}\text { - successful leadership is the result of a co-constructive process } \\
\text { involving leaders and followers. }\end{array}$ & $\begin{array}{l}\text { - Staff } \\
\text { - Organisation }\end{array}$ & \\
\hline $\begin{array}{l}\text { - most effective leaders score high in emotional } \\
\text { intelligence } \\
\text { - includes the characteristics of self-awareness, self- } \\
\text { regulation, motivation and social skill } \\
\text { - Narrative leadership involves harnessing the power } \\
\text { of tsory and narrativiv to oimprover communication } \\
\text { - willingness to hear and learn from patients stories, } \\
\text { and to deliberately and co-operatively use such } \\
\text { stories to change for the better }\end{array}$ & $\begin{array}{l}\text { Narrative leadership skills can help create environments of trust } \\
\text { and openness, inspiring and driving new and better directions for } \\
\text { improvement }\end{array}$ & $\begin{array}{l}\cdot \bullet \text { Patients } \\
. \text { Staff } \\
\text { Organisation }\end{array}$ & \\
\hline $\begin{array}{l}\text { - changing the way they present themselves to others } \\
\text { to improve professional relationships and clinical } \\
\text { enviroment } \\
\text { - looking at problems from a different perspective }\end{array}$ & $\begin{array}{l}\text { - Evaluations demonstrtated tangible learning from the programme } \\
\text { Staff could articulate the benefits of using a framework to address } \\
\text { challenges }\end{array}$ & $\begin{array}{l}\cdot \text { Patients } \\
\text { : Staff } \\
\cdot \text { Organisation }\end{array}$ & $\begin{array}{l}\text { Covey 2004) } 7 \text { Habits } \\
\text { of Highly Effective } \\
\text { People }\end{array}$ \\
\hline 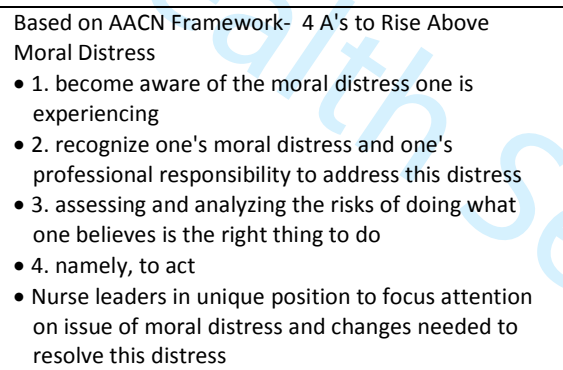 & \begin{tabular}{|l|l} 
- AACN's AA's framework enables nurse leaders and professionals \\
to reduce moral distress in the work environment
\end{tabular} & $\begin{array}{ll}- \text { Staff } \\
\text { Organisation }\end{array}$ & $\begin{array}{l}\text { AACCN' 4A's } \\
\text { framework- (American } \\
\text { Assocition of Critical } \\
\text { Care Nurses) }\end{array}$ \\
\hline 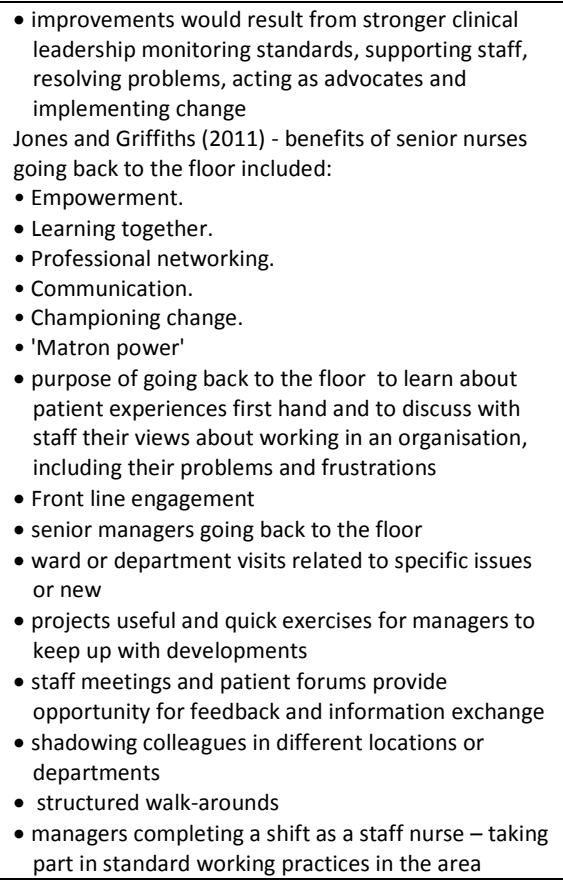 & 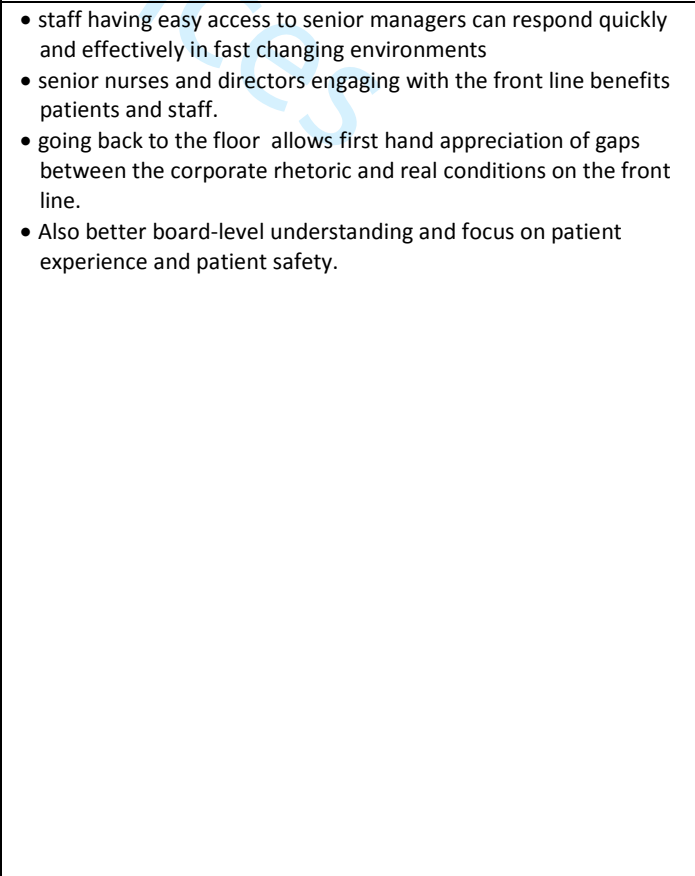 & $\begin{array}{l}\text { - Patients } \\
\text { - Staff } \\
\text { Organisation }\end{array}$ & \\
\hline
\end{tabular}




\begin{tabular}{|c|c|c|c|c|c|c|c|c|}
\hline & & & & & 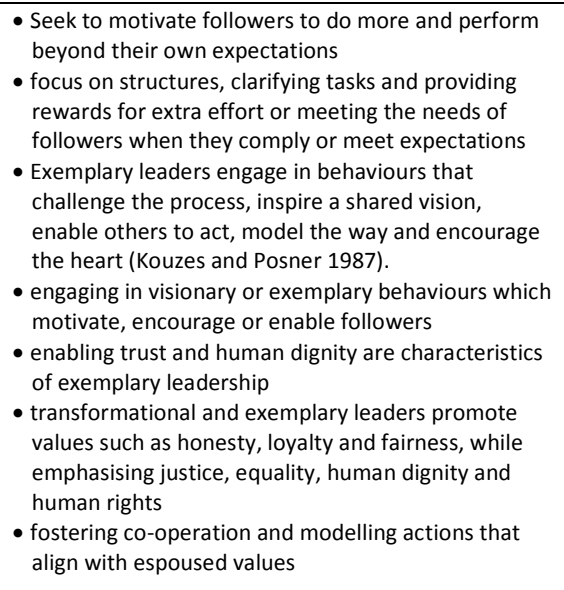 & & & \\
\hline 95 & 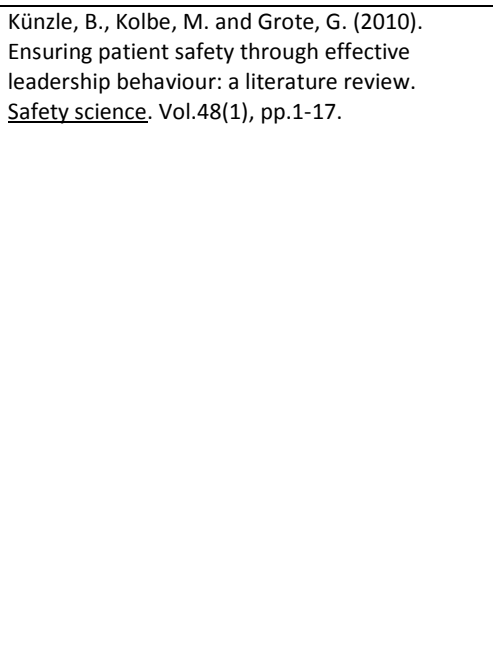 & Literature review & 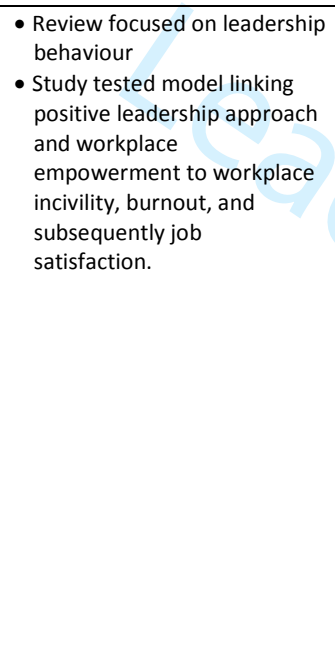 & 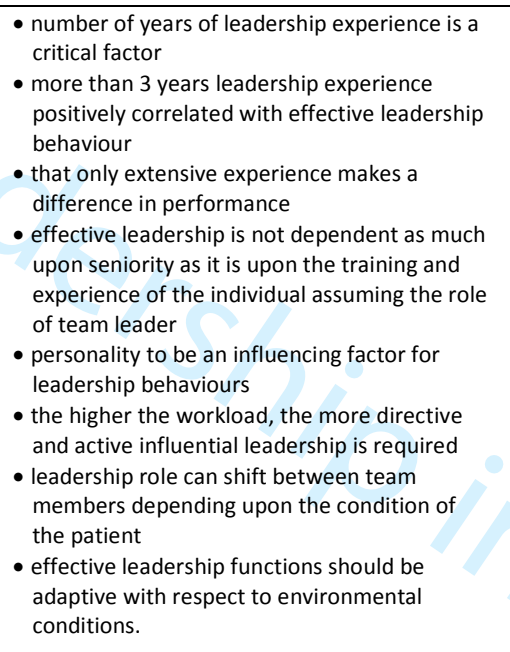 & 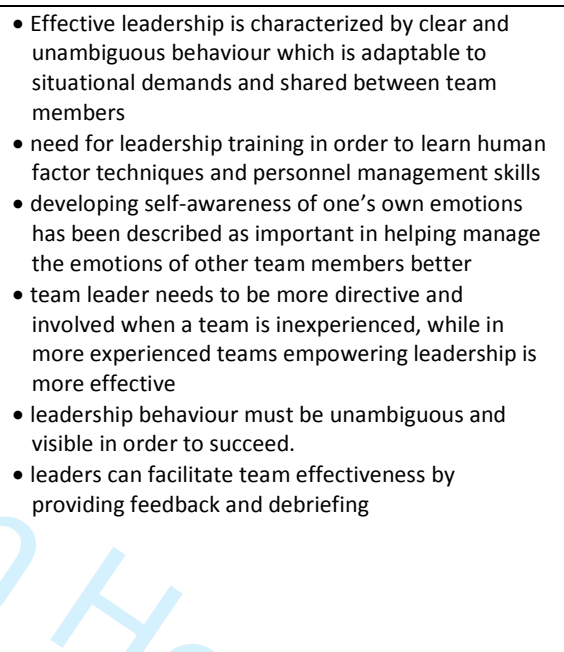 & 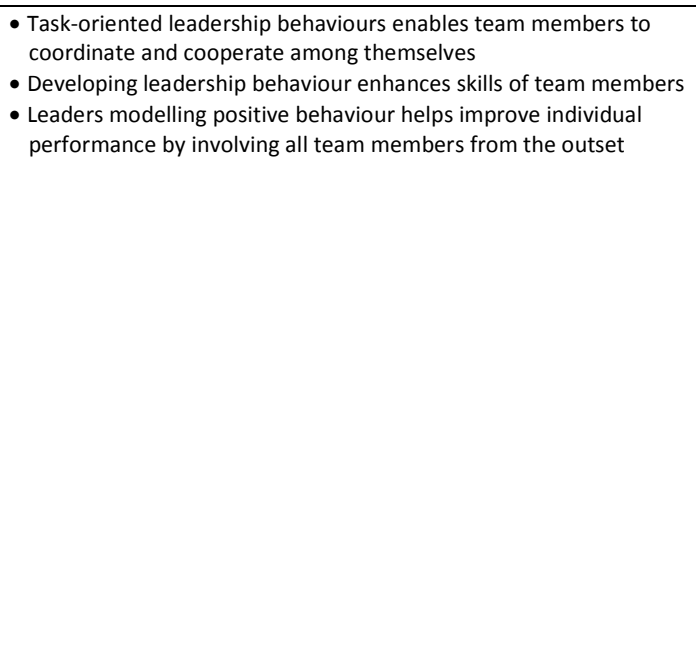 & - Staff & \\
\hline 96 & 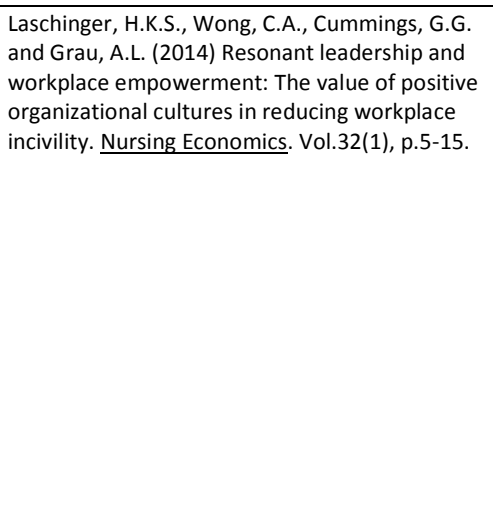 & $\begin{array}{l}\text { Paper is part of a larger } \\
\text { national study of nurses' } \\
\text { worklives }\end{array}$ & Canadian Study & $\begin{array}{l}\text { - Paper supports the notion of resonant } \\
\text { leadership }\end{array}$ & $\begin{array}{l}\text { - Resonant leadership styles include visionary, } \\
\text { coaching, affiliative, and democratic approaches }\end{array}$ & 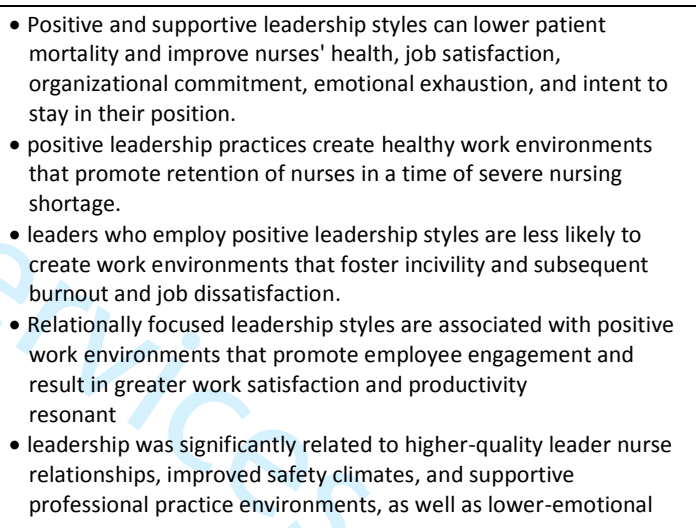 & - Staff & $\begin{array}{l}\text { Resonant leadership, a } \\
\text { relatively new theory } \\
\text { of relationshif-ocused } \\
\text { leadership approach }\end{array}$ \\
\hline 97 & 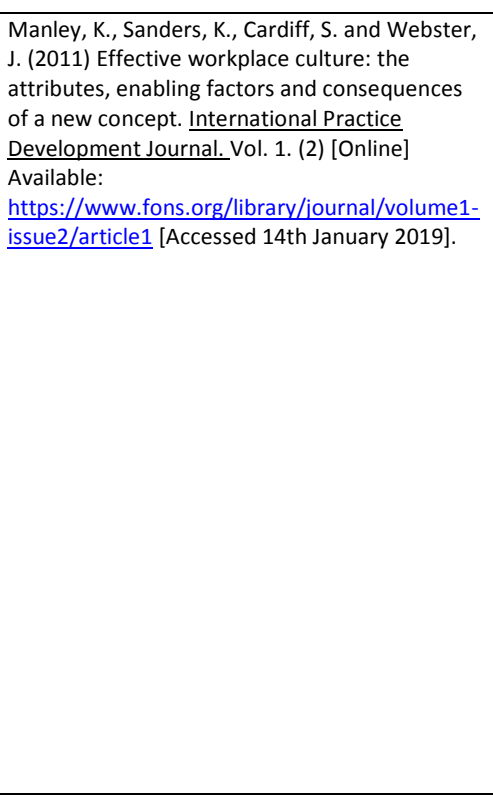 & $\begin{array}{l}\text { Literature review/ concept } \\
\text { analysis }\end{array}$ & 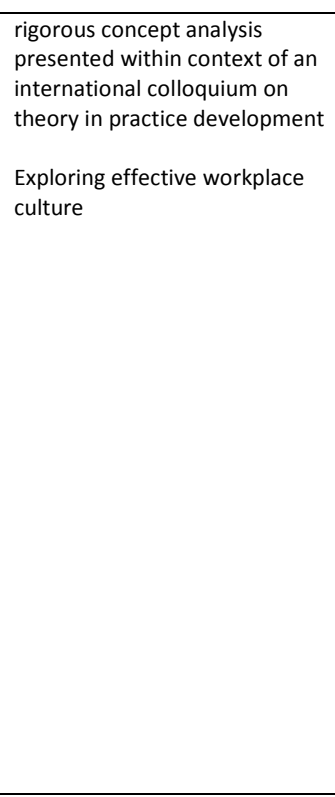 & 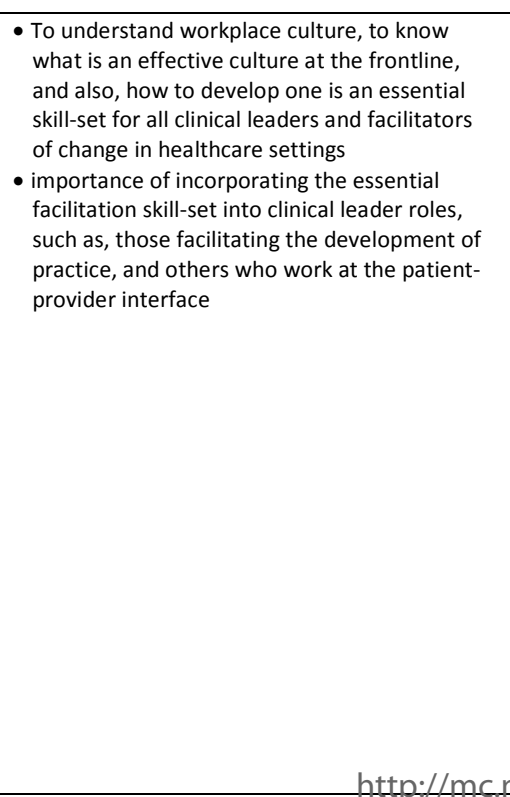 & 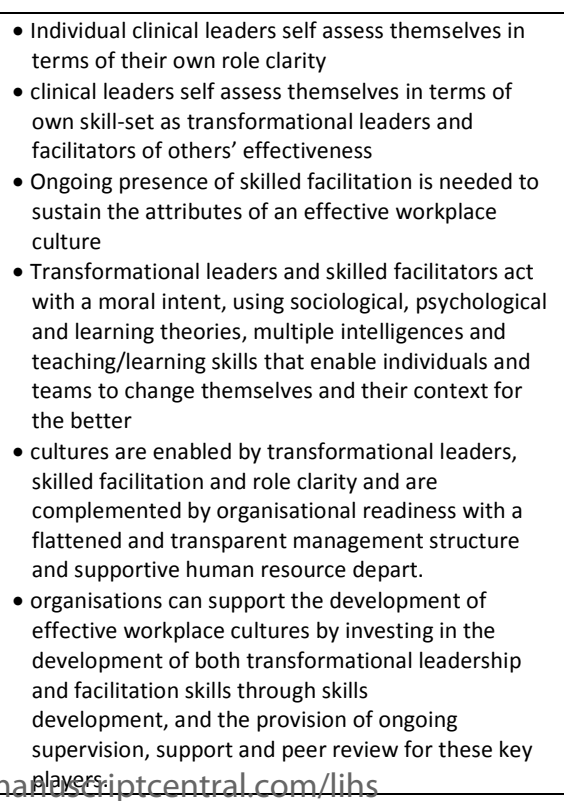 & 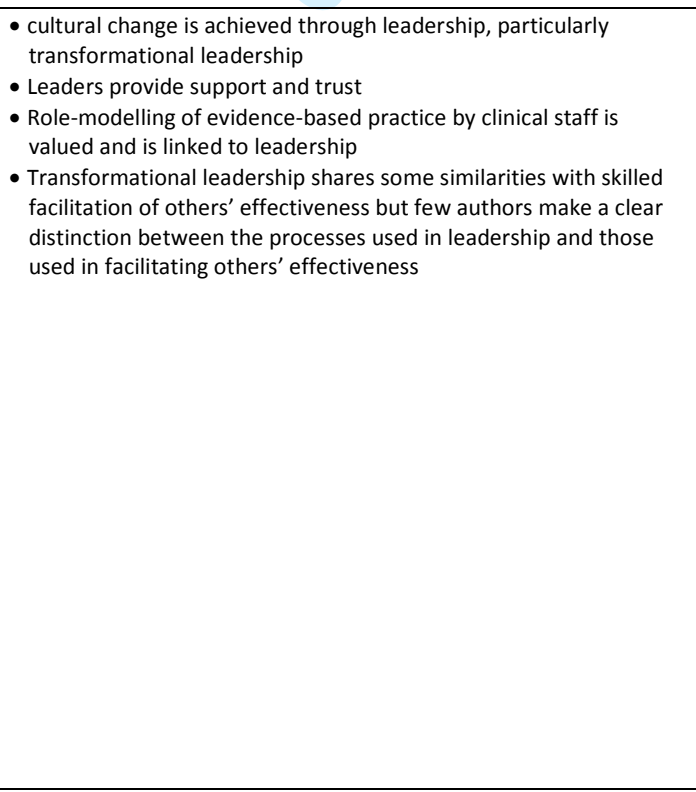 & - Staff & \\
\hline
\end{tabular}




\begin{tabular}{|c|c|c|c|c|c|c|c|c|c|}
\hline${ }_{1}$ No & & Reference & tegory & & text & Mechanisms & Outcomes & Impact on whom & Notes \\
\hline $\begin{array}{l}5 \\
6 \\
7 \\
8 \\
9 \\
10 \\
11 \\
12 \\
13 \\
14 \\
15 \\
16 \\
17 \\
18 \\
19 \\
20\end{array}$ & 98 & 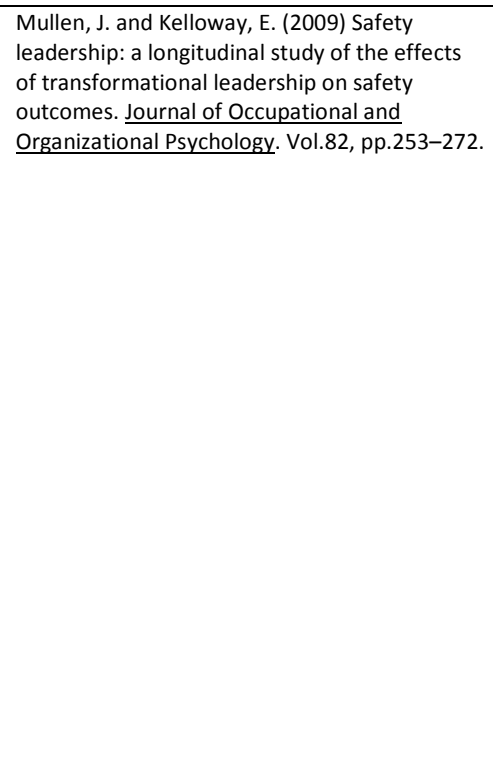 & Research & $\begin{array}{l}\text { longitudinal study of } \\
\text { effects of transformational } \\
\text { leadership on safety } \\
\text { outcomes } \\
\text { Canadian Study }\end{array}$ & 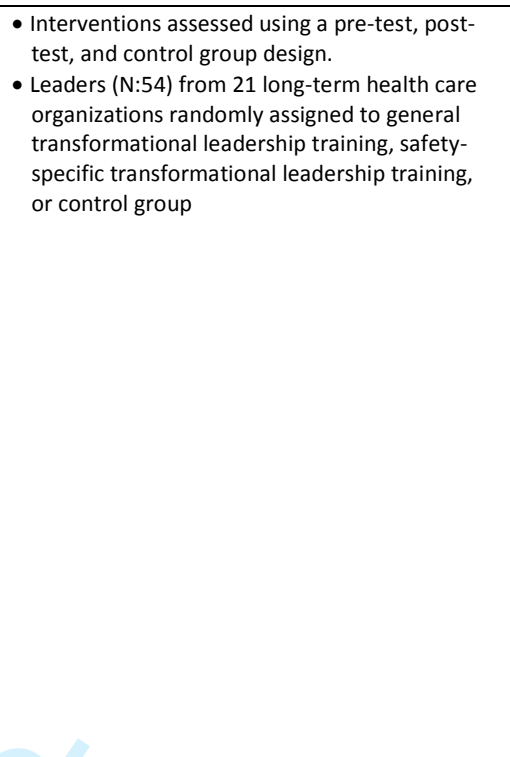 & 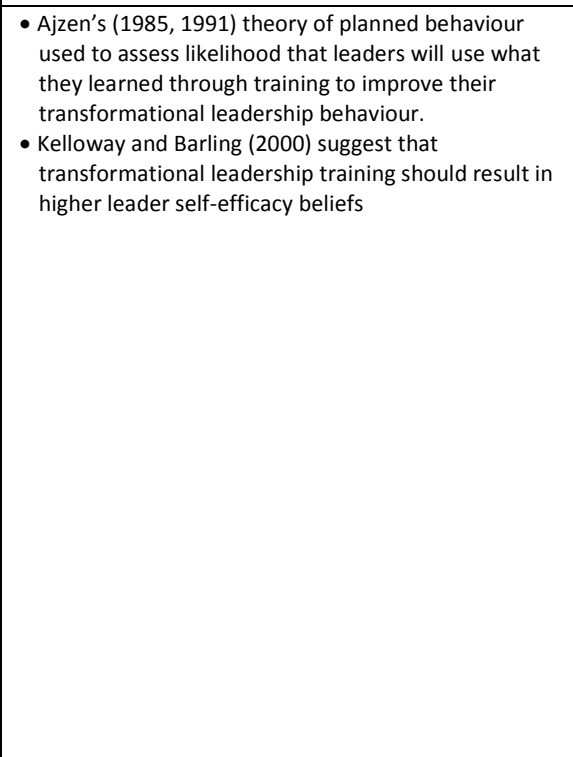 & 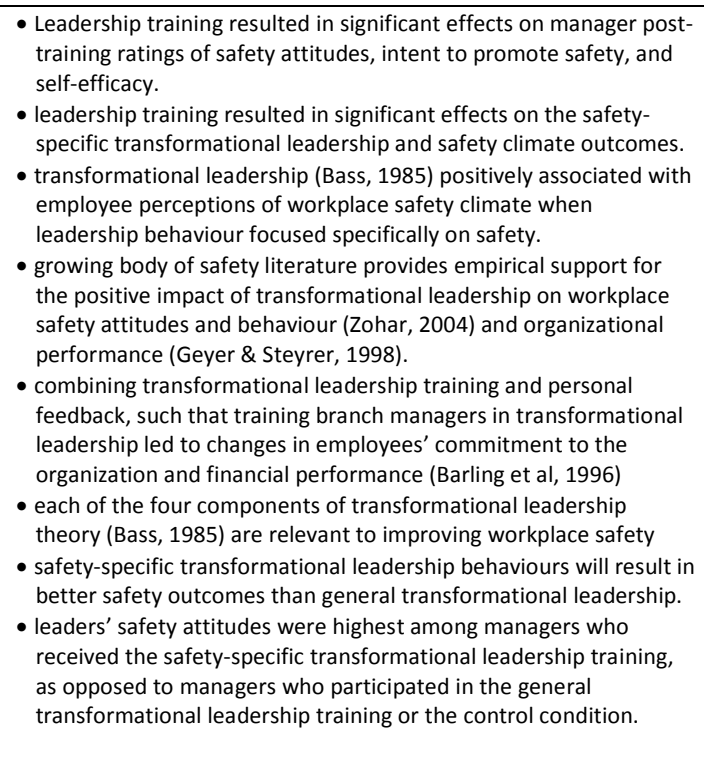 & $\begin{array}{l}\text { - Staff } \\
\text { - Culture } \\
\text { - Organisation } \\
\text { - Patient safety }\end{array}$ & $\begin{array}{l}\text { Ajzen's }(1985,1991) \\
\text { theory of planned } \\
\text { behaviour }\end{array}$ \\
\hline $\begin{array}{l}21 \\
22 \\
23 \\
24 \\
25 \\
26 \\
27 \\
28 \\
29 \\
29 \\
30 \\
31 \\
32 \\
33 \\
34 \\
35 \\
36 \\
37 \\
38 \\
39 \\
40 \\
41 \\
42\end{array}$ & 99 & 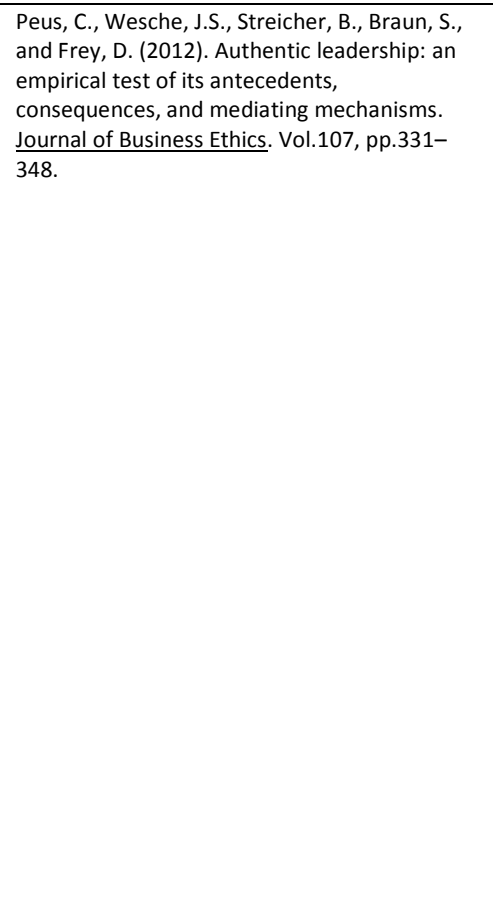 & Literature review & 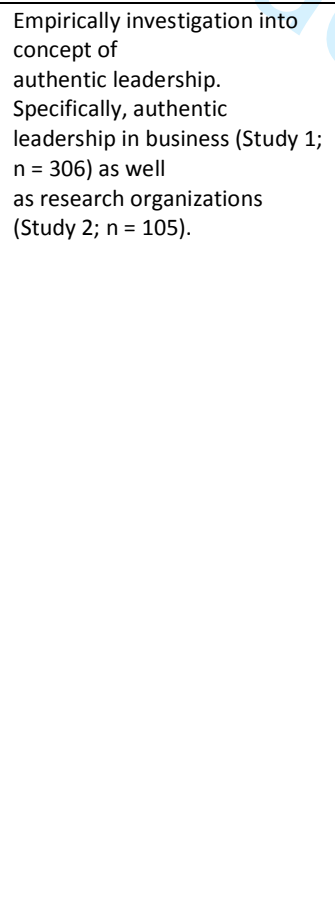 & 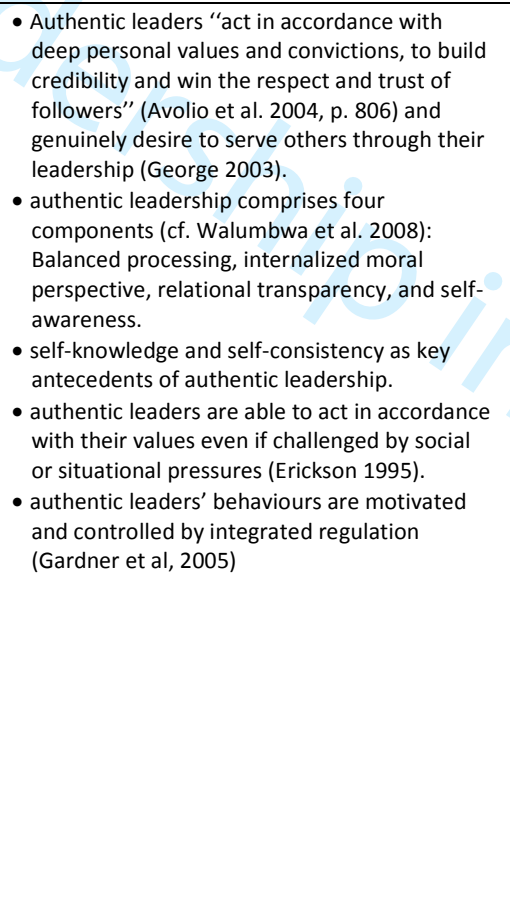 & 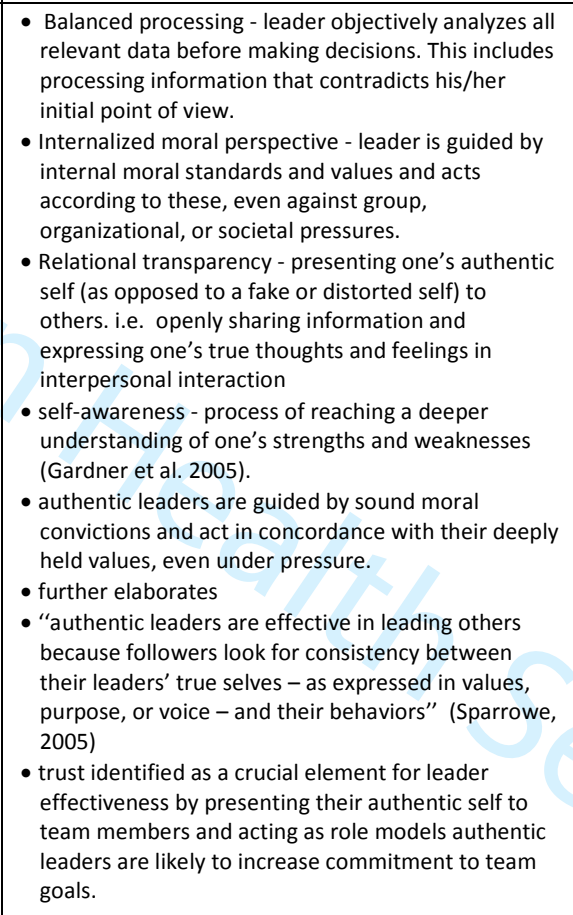 & 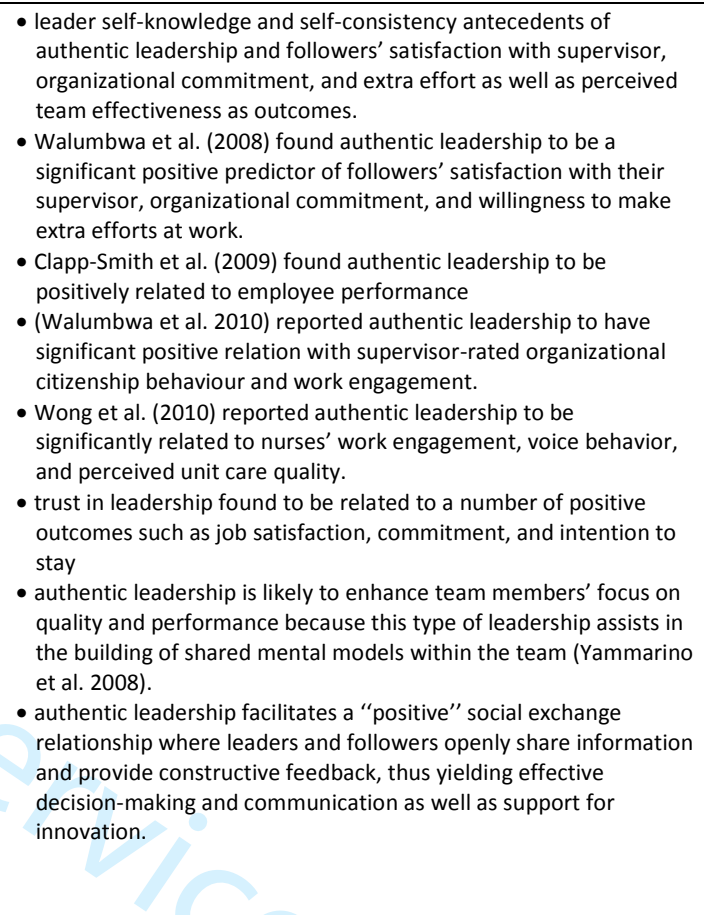 & $\begin{array}{l}\cdot \text { - Staff } \\
\text { Organisation }\end{array}$ & \\
\hline $\begin{array}{l}44 \\
44 \\
45 \\
46 \\
47 \\
48 \\
49 \\
50\end{array}$ & 100 & $\begin{array}{l}\text { Sandstrtom, B., Borglin, G., Nilsson, R., and } \\
\text { Willman, A. (2011). Promoting the } \\
\text { implementation of evidence--based practice: A } \\
\text { literature review focusing on the role of } \\
\text { nursing leadership. Worldviews on Evidence- } \\
\text { Based. Vol.8(4), pp.212-223. }\end{array}$ & Literature review & Authors from Sweden & 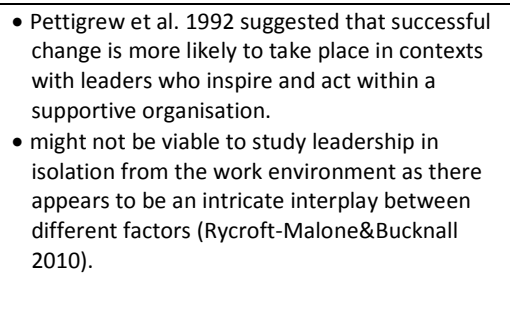 & 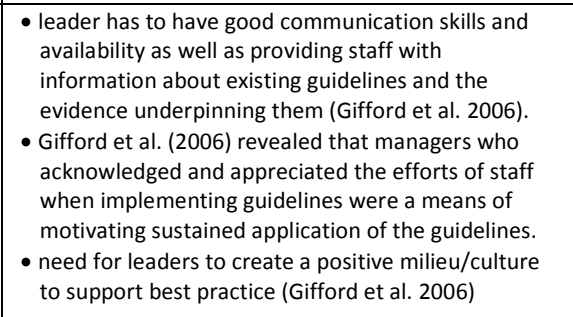 & 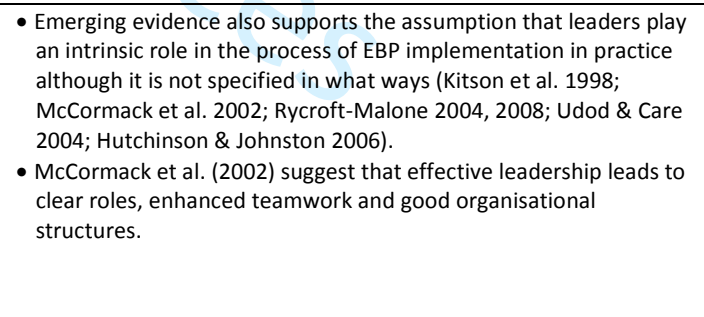 & $\begin{array}{l}\text { : Staff } \\
\text { Organisation }\end{array}$ & \\
\hline $\begin{array}{l}52 \\
53 \\
54 \\
55 \\
56 \\
57 \\
58 \\
59 \\
60\end{array}$ & 101 & 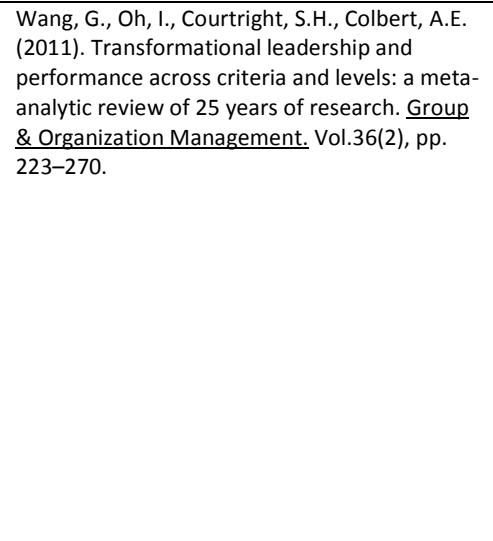 & $\begin{array}{l}\text { Meta- analytic } \\
\text { study of } 113 \text { primary studies }\end{array}$ & Authors from USA & 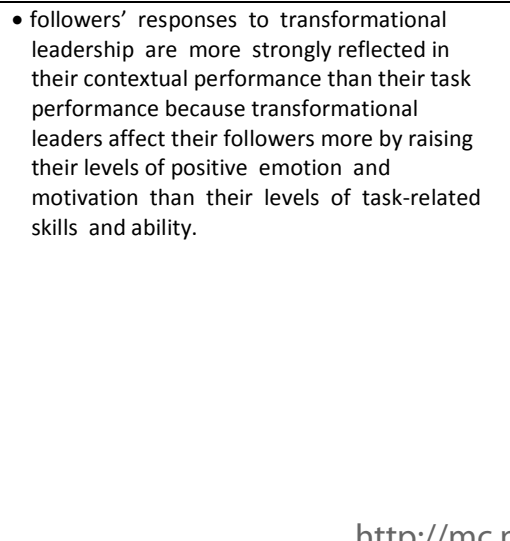 & 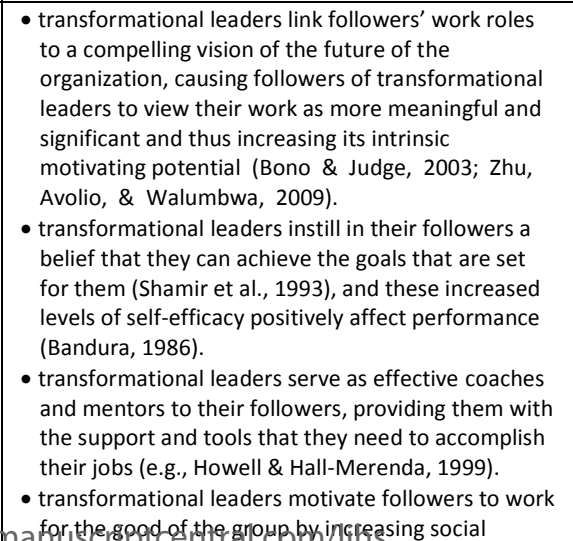 & 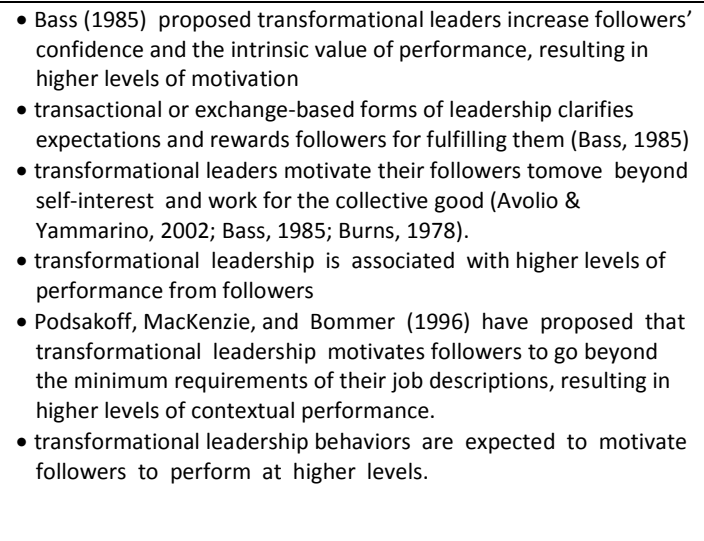 & $\begin{array}{l}\text { - Staff } \\
\text {-Patients } \\
\text {-Organisation }\end{array}$ & \\
\hline
\end{tabular}


Research studies have consistently found positive relationships
between transformational leadership and task performance (e.G

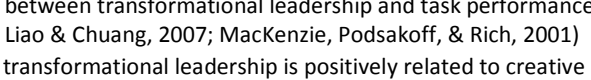
- transformationa
performance. - increasing team cohesion, motivation, and goal congruence within higher levels of organizational performance (Colbert Kristof. Brown, Bradley, \& Barrick, 2008; Waldman \& Yammarino, 1999). - ransactional leaders may motivate higher levels of team
performance by clariffing team goals and rewarding the team for the achievement of those goals - rransformational leadership is positively related to individual - transformational leadership has positive relationshion with - transformation
follower task - gastormational leadership was also positively related to follower - transformational leadership is more strongly related to
follower contextual performance than to follower task

- Transformational leadership was found to be positively related to - overall team performancrice and significiantly associtited with
organizational performance.
- transformational leadership - elationship with team performance
rence - transformational leadership exhibits a positive relationship with performance across several individual performance criteria, Influence of transformational leadership is stronger for contextual performance than for task performance across most
study settings examined.

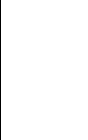




\section{Context}

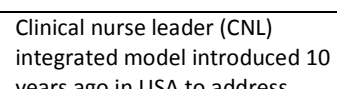
intears ago in USA to address
yes quality and safety gaps.
The ccLL is a Registered Nurse The CNL is a Registered Nurse
with a Master's level education and advanced competencies
clinical leadership, care clinical leadership, care
environment management and
clinical outcomes management Rationale for study is that theoretical clarity is is required to
support effectiveness of this support effectiveness of this 4 Domains of CNL practice:

Preparing for CNL
practice

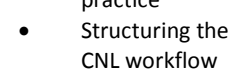

- CNL practice

- CNL outcomes

CNL practice integration is not hands' into a dysfunctional care delivery system with hopes
solving entrenched care solving entrenched care
problems, but rather a systematic process that requires
multilivel organizational input: significant resource allocation and commitment to care deliver
redesign from leaders and redesign from leaders and
practitioners across organizational levels to produce
consistent care quality and safety

Clinical leadership has been complex process of managing relationships at the microssystem level to facilitate the
restructuring of multirest
Get care delivery processes to improve care quality and has
been conceived as a new model requires sustained effort that requires sustained feffort
and appropriate and supportive Medical staff, UK

Entering 'turbulent' period in healthcare were cost framework for all professions Concerns over leadership rolose being away from
patients Term clinical leadershien not well fefined Lack of leadership in early medical training Clinicians moving into more integral decision making Lack of clarity around leadership roles and definitions 1) facilitate effective (2) strengthen intro tols and rounding structures: relationships by
establishing a network of multi-professional partners who previously worked in isolation; (3) create and sustain teams by bringing people from
all disciplines and departments affected by care processes to work together
and improve them; and
(a) ongoing, consistents supportive presence, the provision of resources based on in-the-moment. staff to perform to their full scope of practice and It is important to note that data from this study independent role based on CNL competencies placed
in a clinical mircsistem considered necessarry structuring elementents that continuous clinical leadership practices by colts at

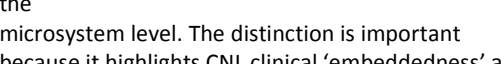
efficiency is required and implementation of reform
etc. Clinicians need to meet demands for a future NHS Medical Leadership Competency Framework

Mechanisms CNL practice identified as a process of ongoing
clinical leadership with the four fundamental a fundamental aspect of practice.$$
\text { . }
$$

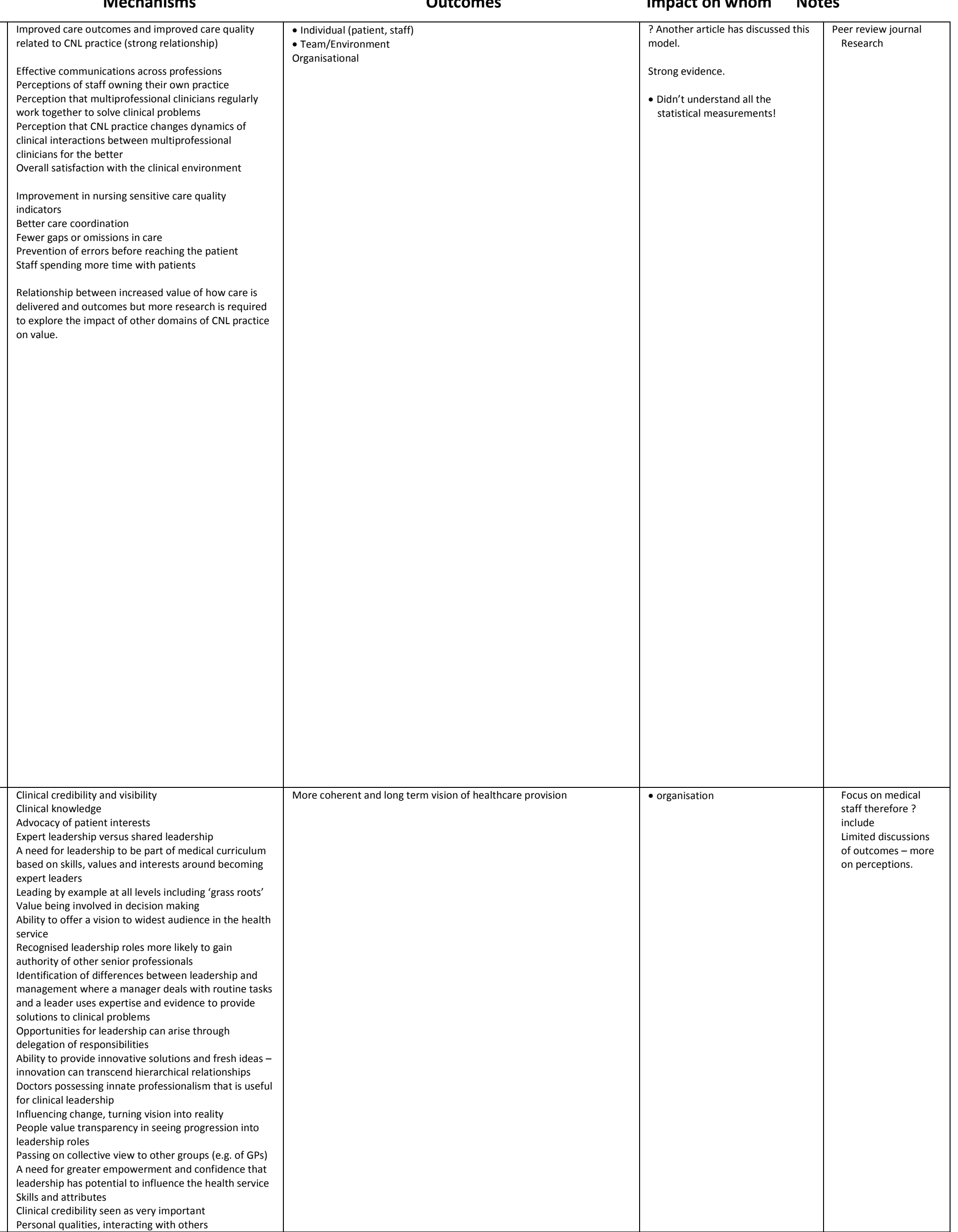




\begin{tabular}{|c|c|c|c|c|c|c|c|c|c|}
\hline \multicolumn{10}{|c|}{ rage 390190} \\
\hline 1 No & & Reference & Category & Setting & Context & Mechanisms & Outcomes & Impact on whom & Notes \\
\hline $\begin{array}{l}2 \\
3 \\
4 \\
5 \\
6 \\
7 \\
8 \\
9 \\
10 \\
11 \\
12 \\
13 \\
14 \\
15 \\
16 \\
17 \\
18 \\
19\end{array}$ & & & & & & 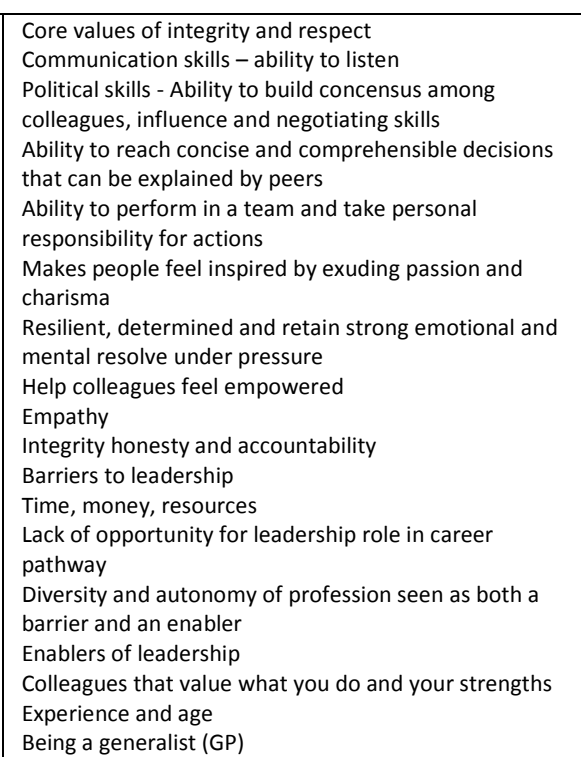 & & & \\
\hline $\begin{array}{l}20 \\
21 \\
22 \\
23 \\
24 \\
25 \\
26 \\
27 \\
28 \\
29 \\
30 \\
31 \\
32 \\
33 \\
34 \\
35\end{array}$ & $\mathrm{~F} 3$ & 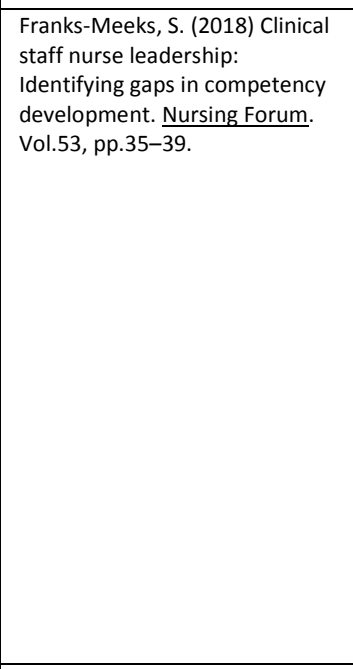 & Literature review & \begin{tabular}{|l|} 
Authors from Texas \\
\end{tabular} & $\begin{array}{l}\text { Lack of research validating clinical staff nurse (CSN) } \\
\text { leadership role, identifying competencies and } \\
\text { invvolving staff nurses in this procecess } \\
\text { Paper discusses validated competencies for Nurse } \\
\text { executivi (NE) and Nurse manager (NM) role but } \\
\text { lack of research validating and involving CSN in CSN } \\
\text { leadership competencies } \\
\text { AONE - American organisation of nurse executives }\end{array}$ & 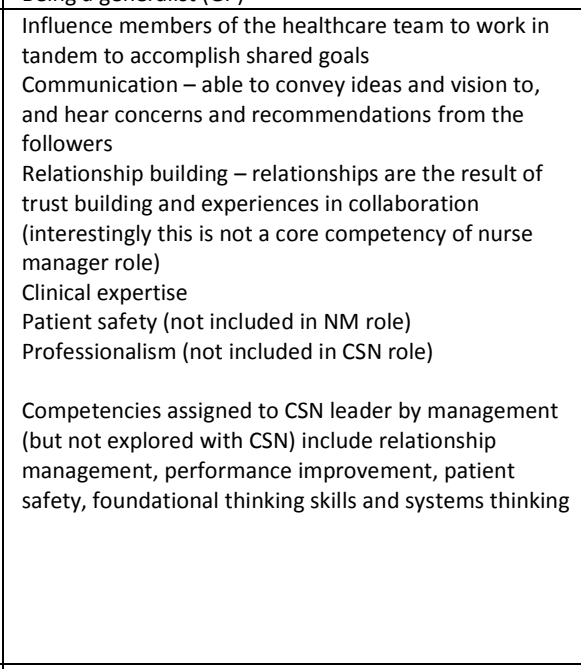 & $\begin{array}{l}\text { - Enhanced patient outcomes - fewer errors, higher satisfaction scores } \\
\text { I mproved organisational and financial success }\end{array}$ & - & 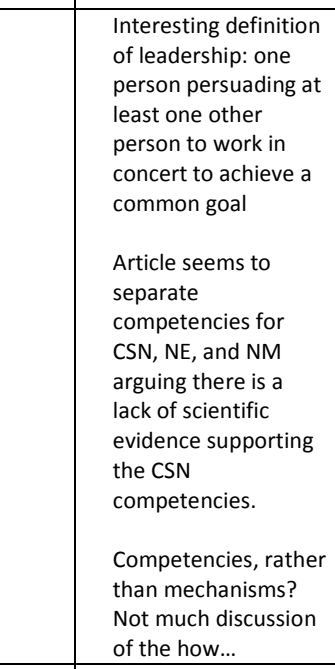 \\
\hline $\begin{array}{l}36 \\
37 \\
38 \\
39 \\
40 \\
41 \\
42\end{array}$ & $\mathrm{~F} 4$ & 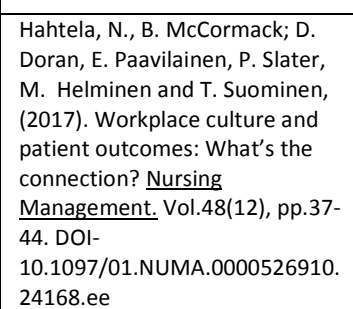 & Research & \begin{tabular}{|l|} 
Finland \\
\end{tabular} & $\begin{array}{l}\text { Study aimed to explore connection between } \\
\text { workplace culture and nursing sensitive patient } \\
\text { outcomes } \\
\text { Cross sectional design } \\
14 \text { healthcare units }\end{array}$ & $\begin{array}{l}\text { Workplace culture - the unit level culture that patients } \\
\text { and staff experience everry day } \\
\text { Managerial support associated with improved } \\
\text { outcomes } \\
\text { Constructs of workplace culture (Nursing Construct } \\
\text { Inndex Questionnaire - Slater and Mccormack) }\end{array}$ & $\begin{array}{l}\text { Nursing sensitive patient outcomes: } \\
\text { Patients pereceptions of self care and patient centred care } \\
\text { Reduced complictions e.g. pressurue injury } \\
\text { Adverse events (related to information, diagnosis, procedures etc.) } \\
\text { RN job satisfaction }\end{array}$ & 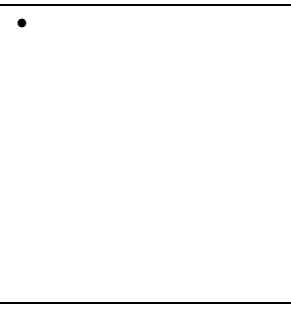 & 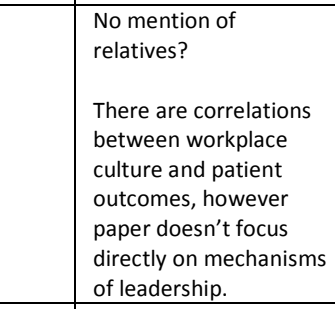 \\
\hline $\begin{array}{l}43 \\
44 \\
45 \\
46 \\
47 \\
48 \\
49 \\
50 \\
51 \\
52 \\
53 \\
54 \\
55 \\
56 \\
57 \\
58 \\
59 \\
60\end{array}$ & $\mathrm{F5}$ & 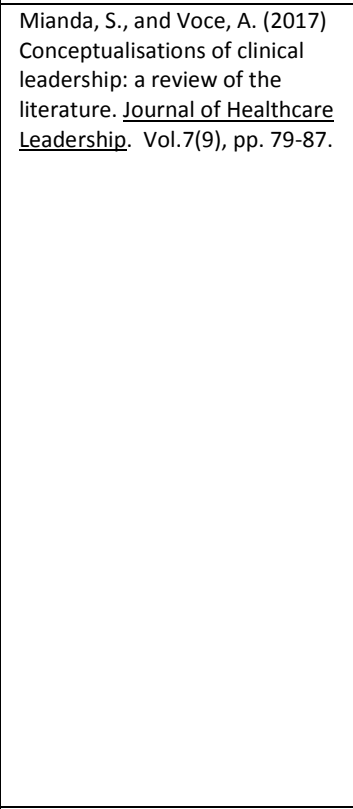 & Systematic literature review & \begin{tabular}{|l|} 
South Africa maternal health \\
Literature review covered papers \\
from Australaia, UK, Ireland, New \\
Zealand
\end{tabular} & 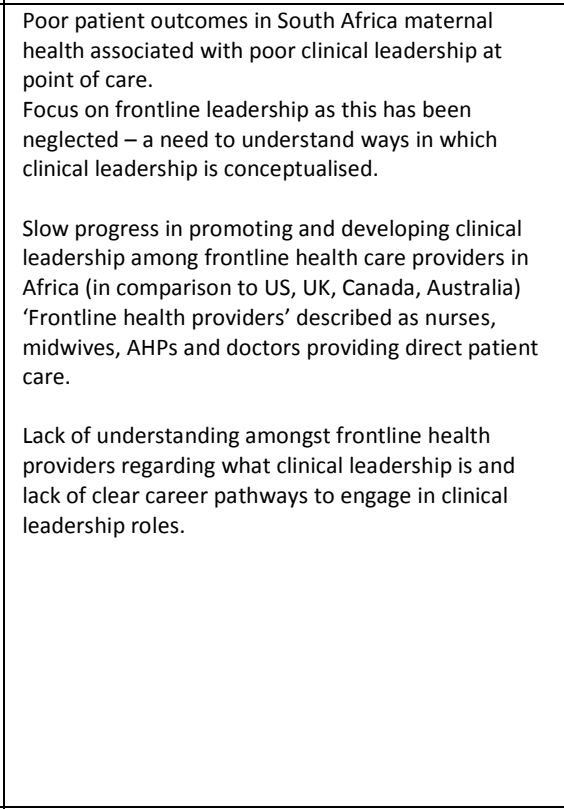 & 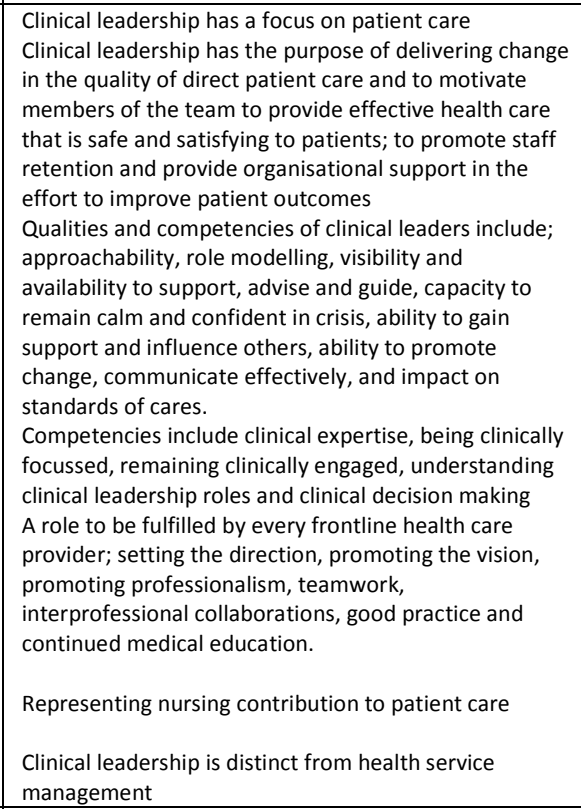 & $\begin{array}{l}\text { Quality patient care/improved outcomes } \\
\text { Staff retention } \\
\text { Healthy and safe clinical work environment }\end{array}$ & $\begin{array}{l}\begin{array}{l}\text { Patient } \\
\text { Teamms } \\
\text { Organisation }\end{array} \\
\end{array}$ & \\
\hline & $\mathrm{F} 6$ & $\begin{array}{l}\text { Murray, M., Sundin, D., Cope, V. } \\
\text { (2018) The eneus of nursing } \\
\text { leadership and a culture of safer }\end{array}$ & \begin{tabular}{|l|} 
Discursive paper- \\
integrative literature review
\end{tabular} & \begin{tabular}{|l|l} 
Authors from Australia \\
\end{tabular} & $\begin{array}{l}\text { Paper explores connection between }+6 \text { leadership } \\
\text { and enhanced patient safety }\end{array}$ & $\begin{array}{l}\text { Visisility of leaders } \\
\text { credible support for patient safety initiatives } \\
\text { Lsystems }\end{array}$ & \begin{tabular}{|l} 
Enhanced patient safety \\
Patient outcomes \\
Employee satisfaction
\end{tabular} & & $\begin{array}{l}\text { Comparison of } \\
\text { transformational and } \\
\text { transactional }\end{array}$ \\
\hline
\end{tabular}




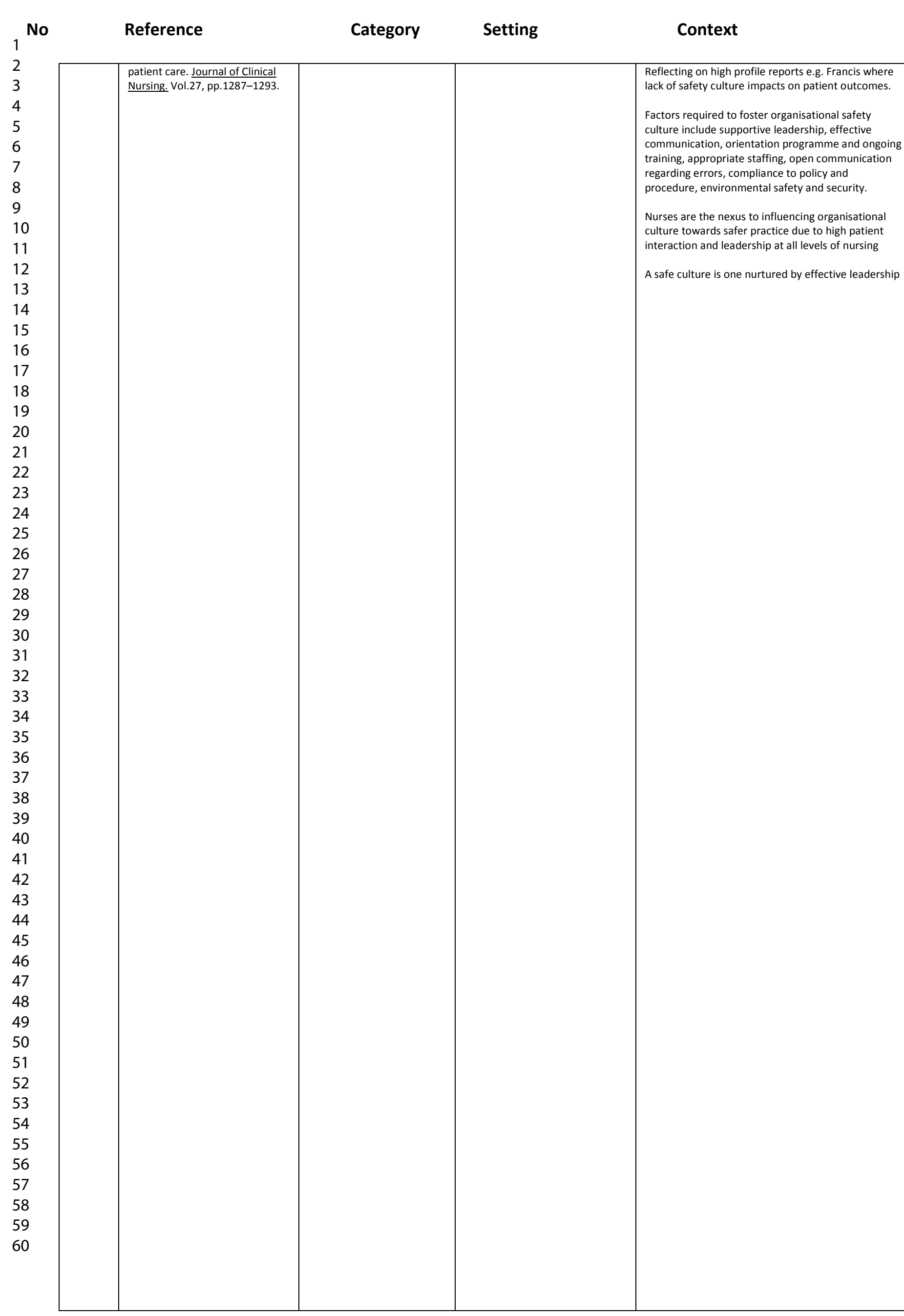

\begin{tabular}{|c|c|c|}
\hline 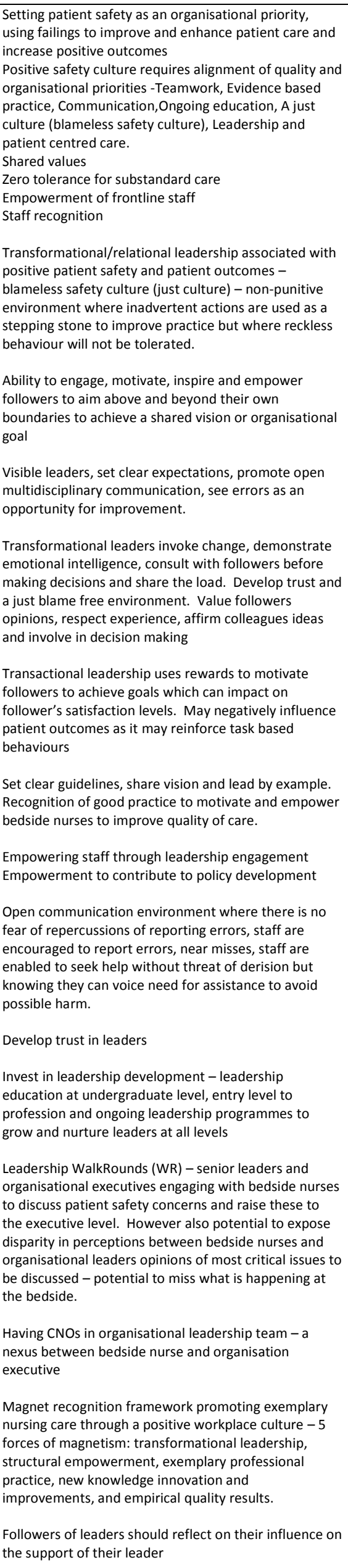 & 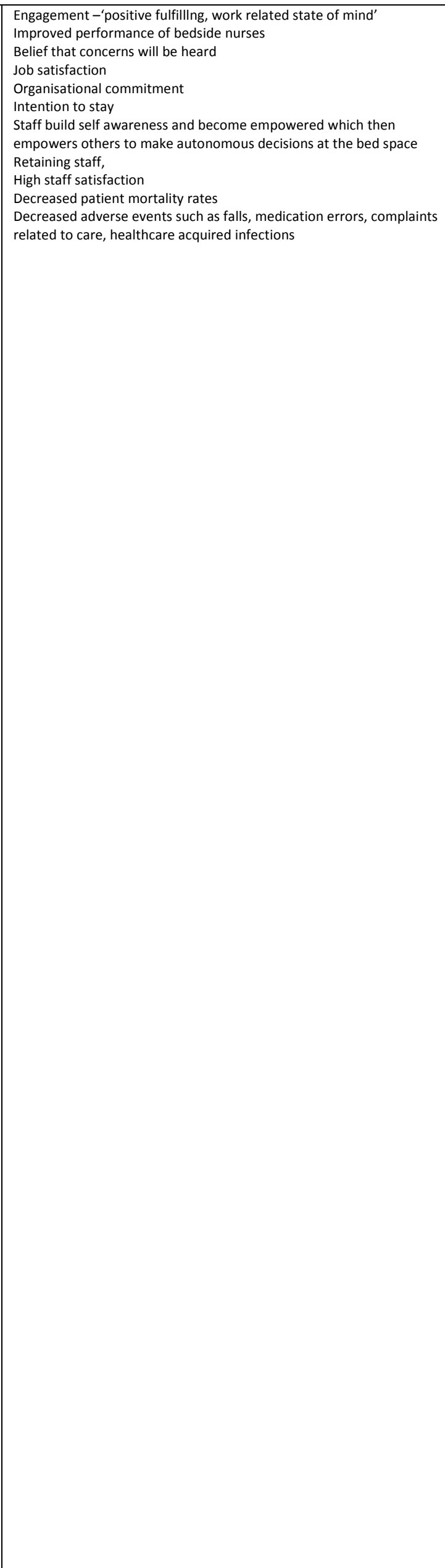 & \begin{tabular}{|l}
$\begin{array}{l}\text { leadership as well as } \\
\text { situational and } \\
\text { democratic. }\end{array}$ \\
\end{tabular} \\
\hline
\end{tabular}




\begin{tabular}{|c|c|c|c|c|c|c|c|c|c|}
\hline${ }_{1}$ No & & Reference & Category & Setting & Context & Mechanisms & Outcomes & Impact on whom & \\
\hline $\begin{array}{l}2 \\
3 \\
4 \\
5 \\
6 \\
6 \\
7\end{array}$ & & & & & & $\begin{array}{l}\text { Responsibility for nurses to seek leadership education, } \\
\text { and develop confidence and competence in leadership } \\
\text { Bedside nurses have most influence on patient } \\
\text { outcome and effective leadership can empower them } \\
\text { to go above and beyond their seff-imposed boundaries } \\
\text { to meet a vision shared by their leader, without fear of } \\
\text { recrimination }\end{array}$ & & & \\
\hline $\begin{array}{l}8 \\
9 \\
10 \\
11 \\
12 \\
13 \\
14 \\
15 \\
16 \\
17 \\
18 \\
19 \\
20 \\
21 \\
22 \\
23 \\
24 \\
25 \\
26 \\
27 \\
28 \\
29 \\
30 \\
31 \\
32 \\
33 \\
34 \\
35 \\
36 \\
37 \\
38 \\
39 \\
40 \\
41\end{array}$ & F7 & 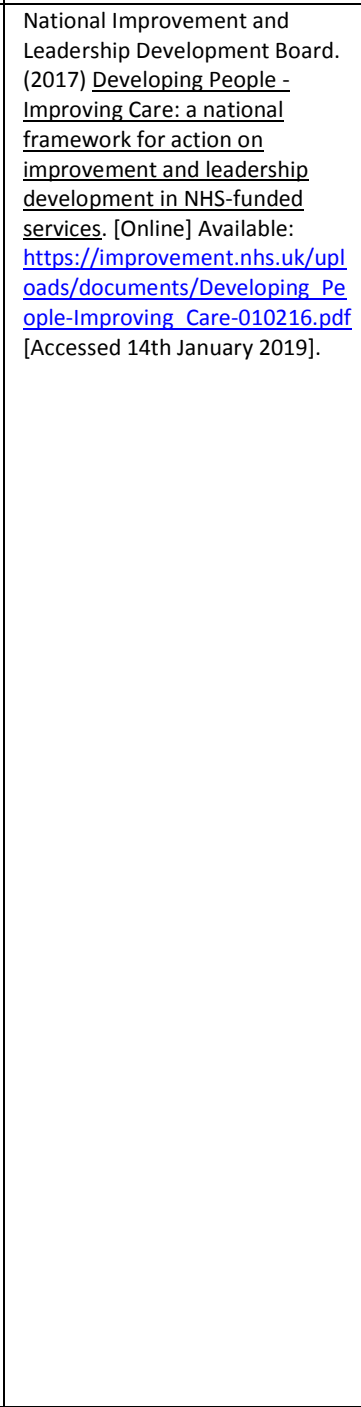 & 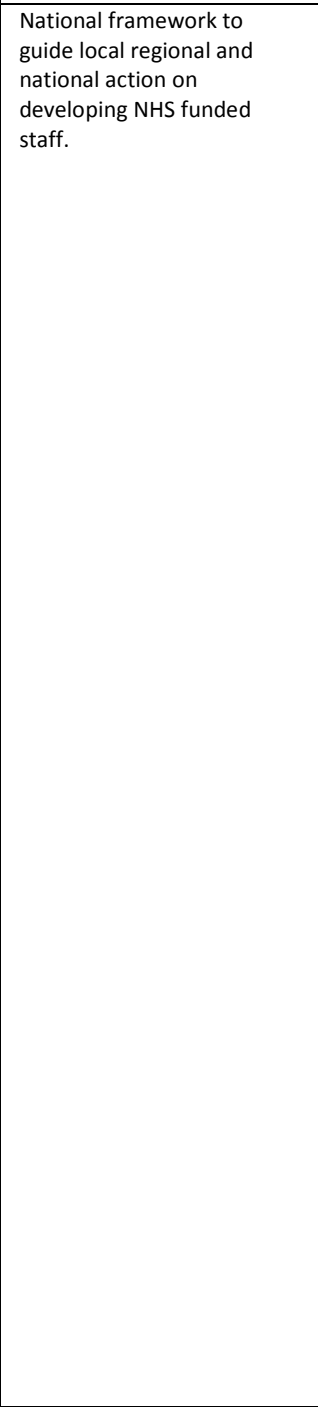 & \begin{tabular}{|l|} 
NHS England \\
Framework for all health \\
professions \\
\end{tabular} & 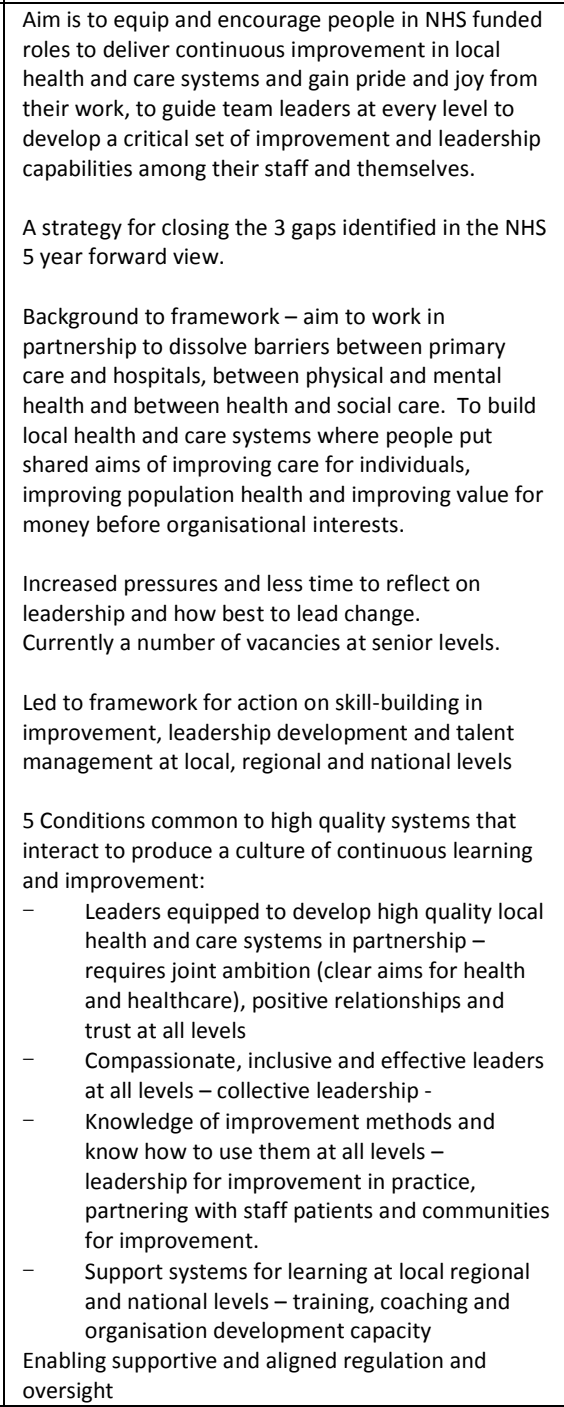 & 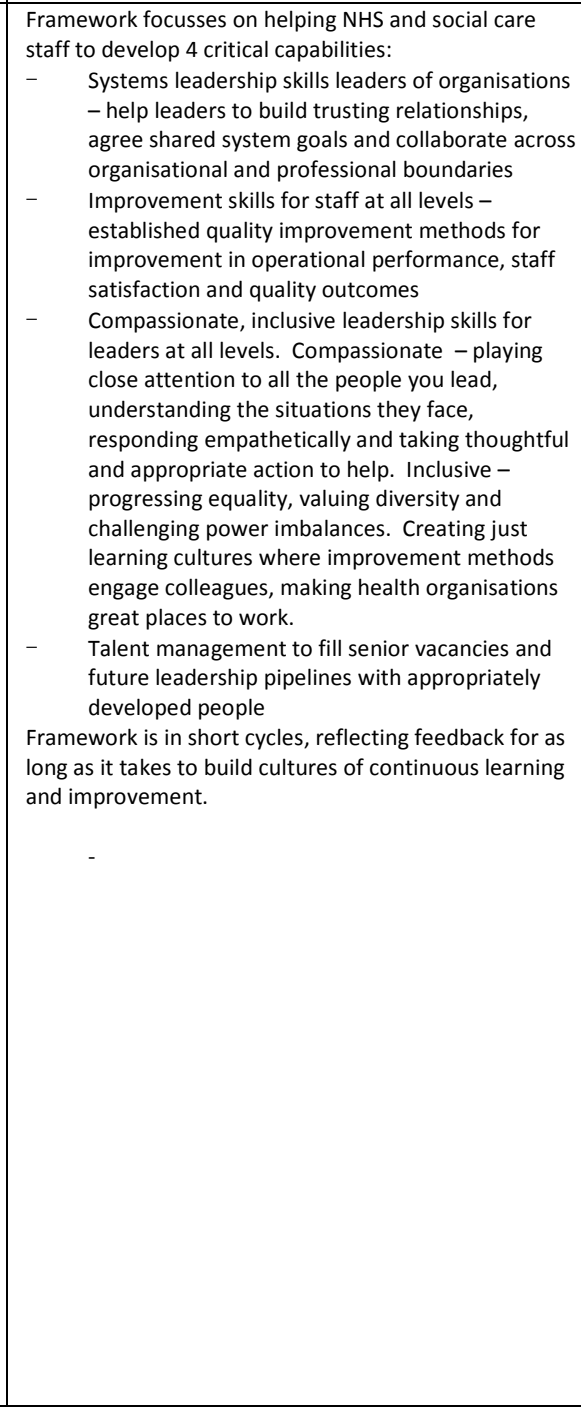 & 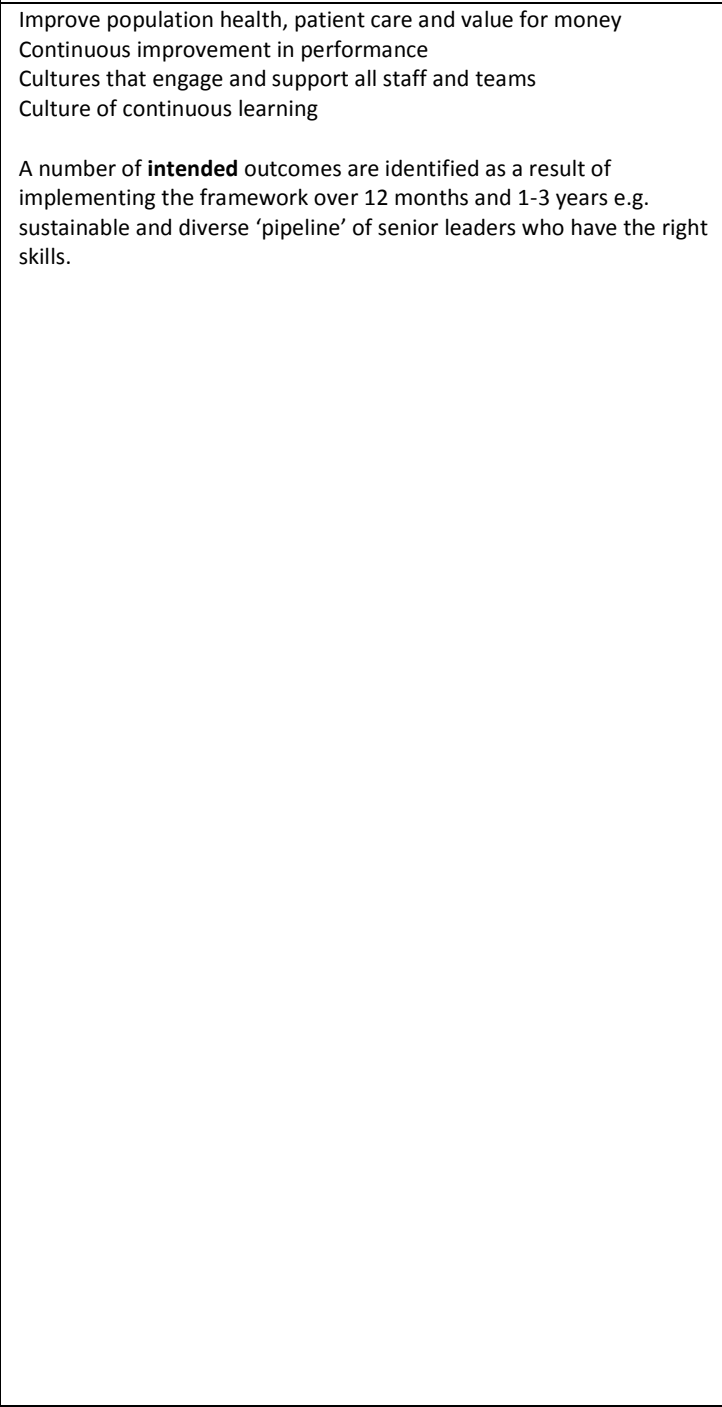 & $\begin{array}{l}\text { Individuals, teams, organisation, } \\
\text { communities }\end{array}$ & 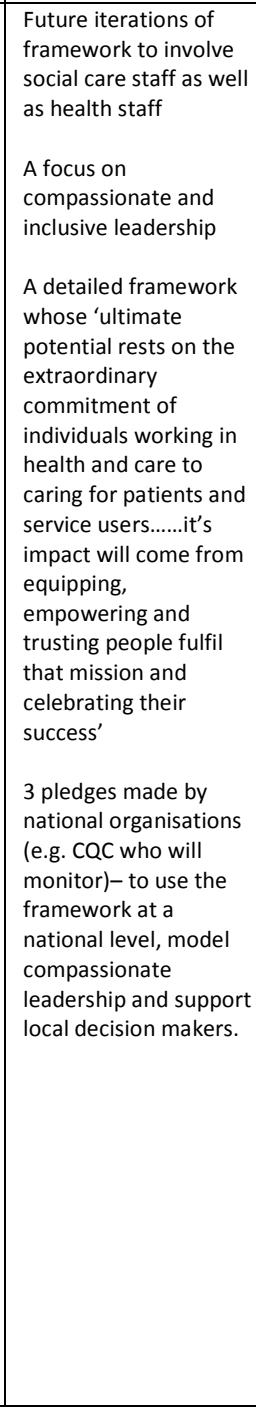 \\
\hline $\begin{array}{l}41 \\
42 \\
43 \\
44 \\
45 \\
46 \\
47 \\
48 \\
49 \\
50 \\
51 \\
52 \\
53 \\
54\end{array}$ & F8 & 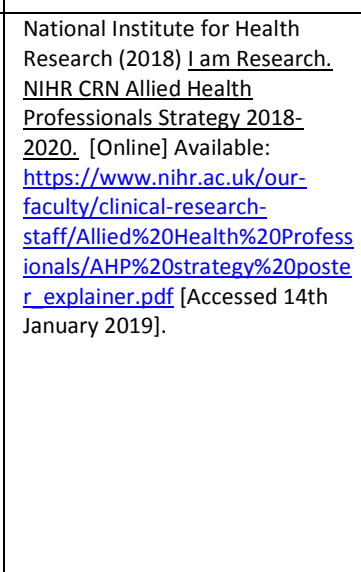 & \begin{tabular}{|l|l|} 
Strategy \\
\end{tabular} & \begin{tabular}{|l|l|} 
UK \\
AHPS
\end{tabular} & 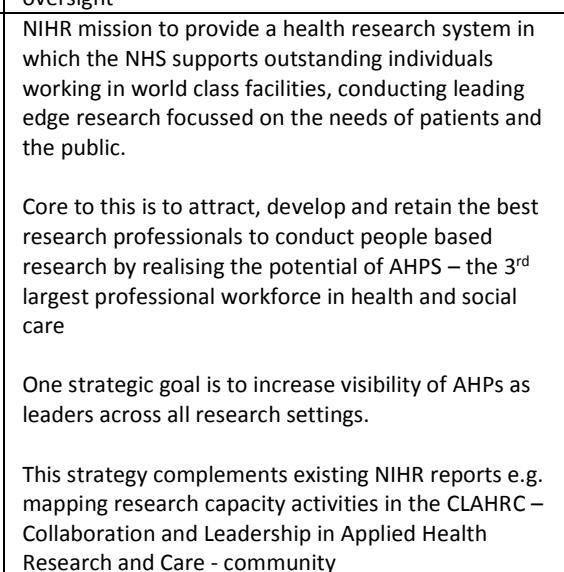 & $\begin{array}{l}\text { Building awareness, demonstrating innovation and } \\
\text { promoting and sharing best practice } \\
\text { Leaders who develop best clinical practice, are NIIR } \\
\text { ambassadors, visible role models and building identity } \\
\text { and momentum for the professions }\end{array}$ & Development of best clinical practice & $\begin{array}{l}\begin{array}{l}\text { Organisations } \\
\text { Individuals }\end{array} \\
\end{array}$ & $\begin{array}{l}\text { ? relevance of this } \\
\text { document - - letated to } \\
\text { APP leadership and } \\
\text { research. }\end{array}$ \\
\hline $\begin{array}{l}55 \\
56 \\
57 \\
58 \\
59 \\
60\end{array}$ & $\mathrm{F9}$ & 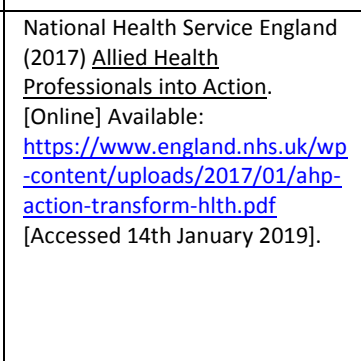 & $\begin{array}{l}\text { Framework to develop plan } \\
\text { of delivery } \\
\text { Reviev of national policy } \\
\text { documents, engagement nd } \\
\text { involvement of senior } \\
\text { leaders }\end{array}$ & \begin{tabular}{|l|l} 
NHS England \\
\end{tabular} & 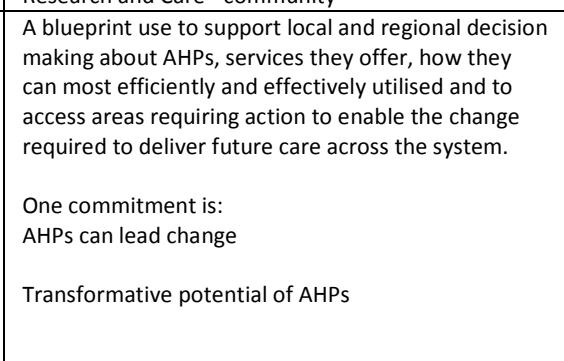 & 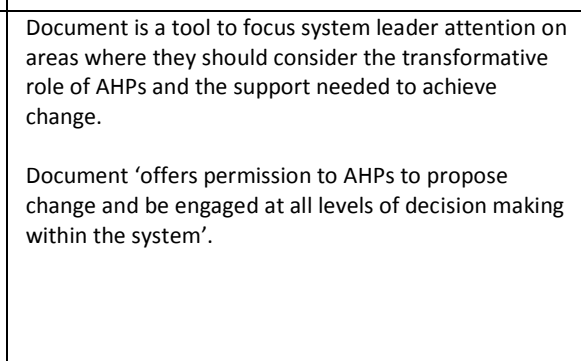 & $\begin{array}{l}\text { Improve health and well-being of individuals and populatitions } \\
\text { Support and provide solutions to general practice and emergency } \\
\text { services to address demand } \\
\text { support integration } \\
\text { Deliver evidence based/informed practice }\end{array}$ & & 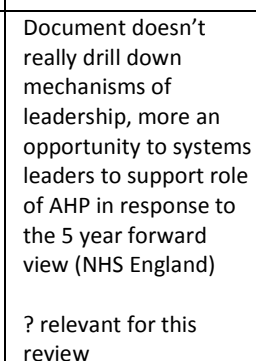 \\
\hline
\end{tabular}




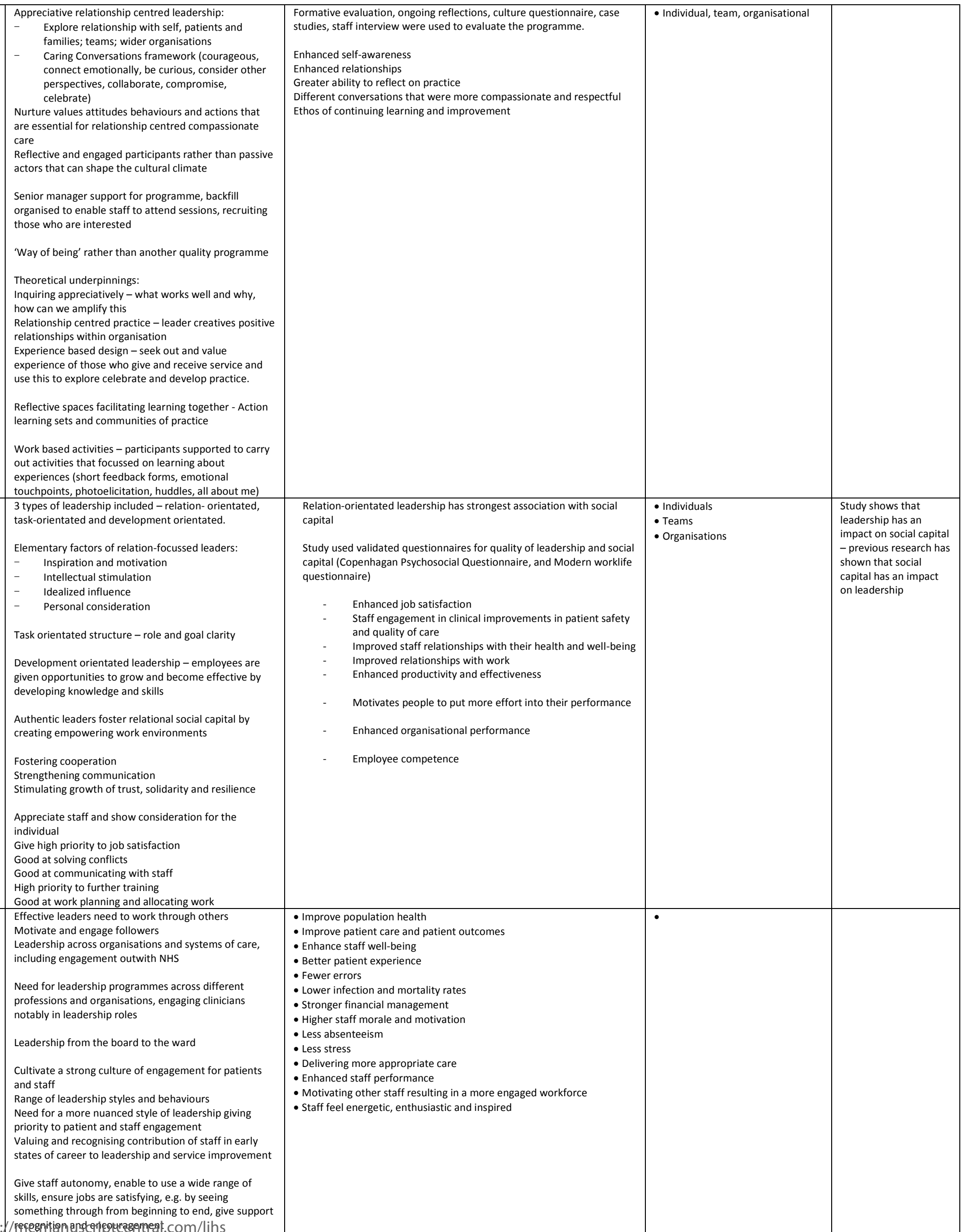




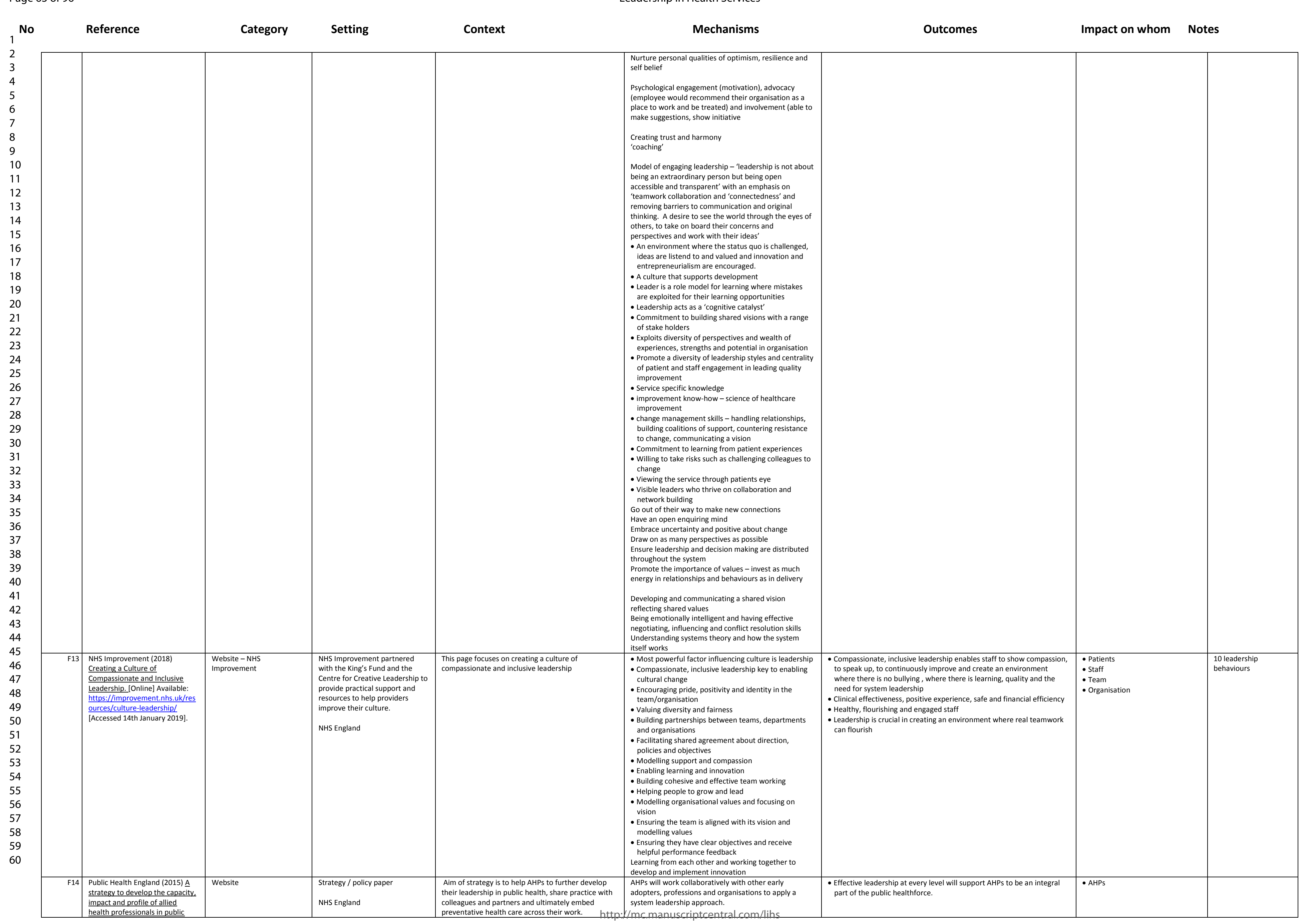




\begin{tabular}{|c|c|c|c|c|c|c|c|c|c|}
\hline${ }_{1}^{\text {No }}$ & & Reference & Category & Setting & Context & Mechanisms & Outcomes & Impact on whom & Notes \\
\hline $\begin{array}{l}2 \\
3 \\
4 \\
5 \\
6\end{array}$ & & \begin{tabular}{|l|} 
health 2015-2018. [Online] \\
Available: \\
httr://www.ahpf.org.uk/files/AH \\
P\%20Public\%2OHealth\%20Strate \\
gy.pdf \\
2019]. \\
\end{tabular} & & & & & & & \\
\hline $\begin{array}{l}7 \\
8 \\
9 \\
10 \\
11 \\
12 \\
13 \\
14 \\
15 \\
16 \\
17 \\
18 \\
19 \\
20 \\
21 \\
22 \\
23 \\
24 \\
25 \\
26 \\
27 \\
28 \\
29 \\
30\end{array}$ & $\mathrm{~F} 15$ & \begin{tabular}{|l} 
Royal College of Speech and \\
Language Therapists (2000) \\
Excellent AHP Leadership \\
Connections. [Online] Available: \\
https://www.rcslt.org/governme \\
nts/docs/leadership_day report \\
[Accessed 14th January 2019].
\end{tabular} & \begin{tabular}{|l|l} 
Website \\
\end{tabular} & $\begin{array}{l}\text { Report of Royal College of } \\
\text { speech hand language therapist. }\end{array}$ & 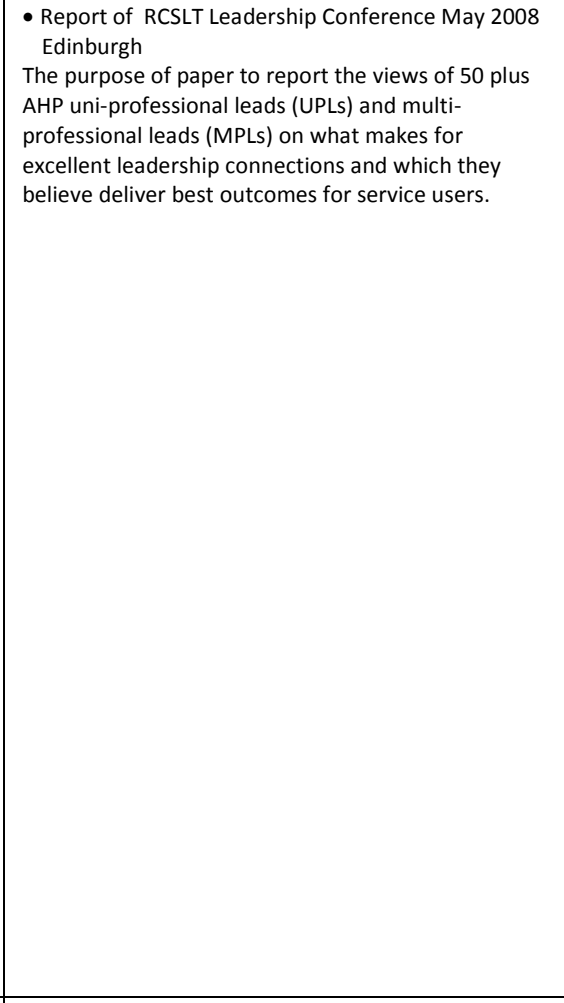 & 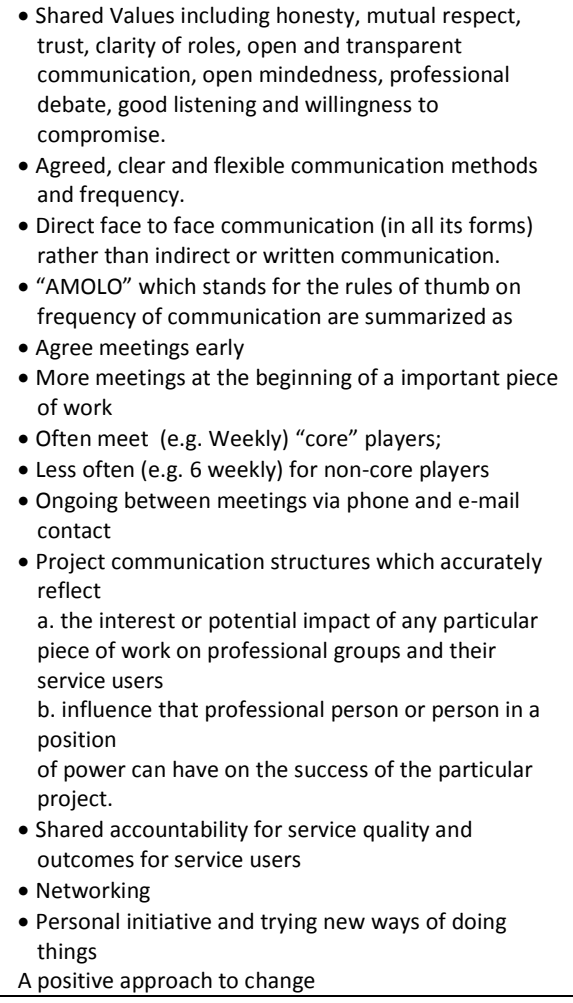 & • & \begin{tabular}{|l} 
Nurses \\
- Teams
\end{tabular} & \\
\hline $\begin{array}{l}31 \\
32 \\
33 \\
34 \\
35 \\
36 \\
37 \\
38\end{array}$ & $\mathrm{~F} 16$ & \begin{tabular}{|l} 
Scottish Government (2017) \\
Nursing 2030 Vision. [online] \\
Available: \\
httr://www.gov.scot/Publication \\
s/2017/07/4277/1 [Accessed \\
14th January 2019].
\end{tabular} & Website & $\begin{array}{l}\text { Nursing } 2030 \text { Vision paper } \\
\text { NHS Scottand }\end{array}$ & 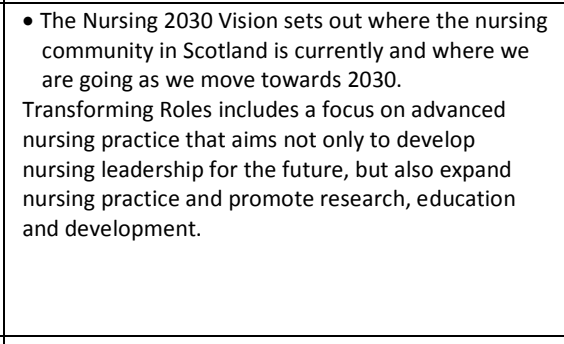 & & 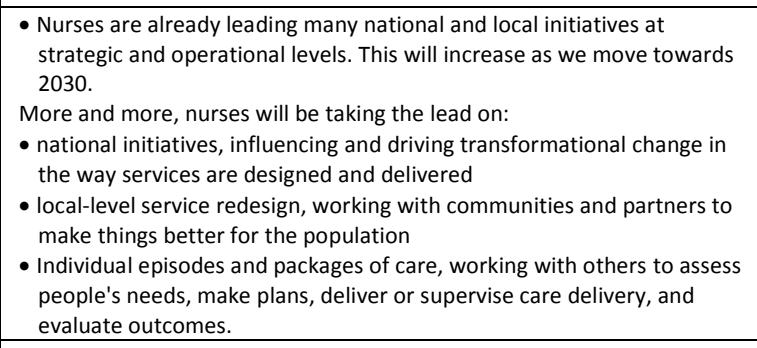 & \begin{tabular}{|l|} 
- Nurse leaders \\
Services
\end{tabular} & \\
\hline $\begin{array}{l}39 \\
40 \\
41 \\
42 \\
43 \\
44 \\
45 \\
46 \\
47 \\
48\end{array}$ & $\mathrm{~F} 17$ & 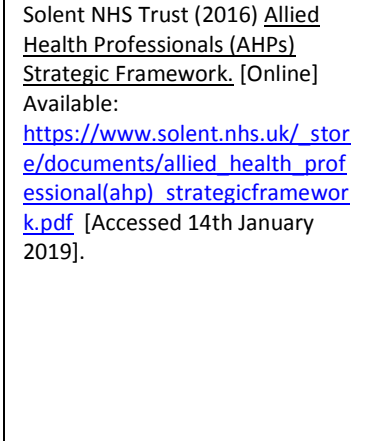 & \begin{tabular}{|l|l} 
Website \\
\end{tabular} & Strategy / policy framework & 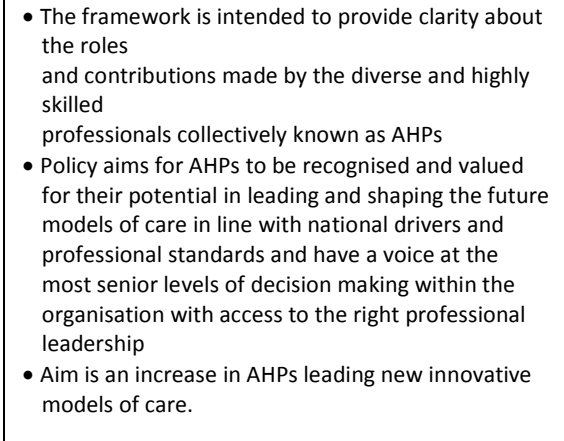 & $\begin{array}{l}\text { - Promoting training and leadership whilst celebratiting } \\
\text { and being inspiried by exammles of APIPs working in } \\
\text { non-traditional roles across integrated care models. }\end{array}$ & $\cdot$ & -AHPs & \\
\hline $\begin{array}{l}49 \\
50 \\
51 \\
52 \\
53 \\
54 \\
55 \\
56 \\
57 \\
58 \\
59 \\
60\end{array}$ & $\mathrm{~F} 18$ & 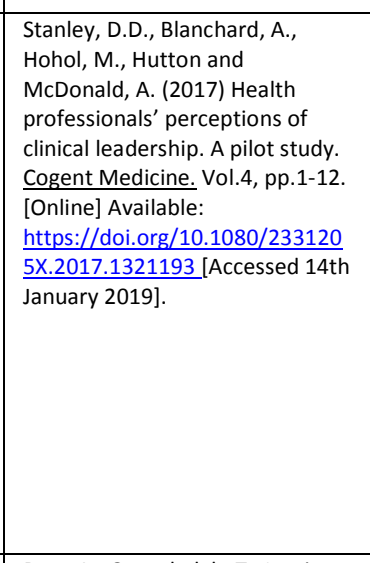 & \begin{tabular}{|l|} 
Website \\
\end{tabular} & $\begin{array}{l}\text { Research article using mixed } \\
\text { methods based in Australia }\end{array}$ & $\begin{array}{l}\text { - To identify how clinical leadership was perceived } \\
\text { by Health } \\
\text { Professionals (HPs) (excluding nurses and doctors) } \\
\text { and to understand how effective clinical leadership } \\
\text { relates to intititing and establishing a culture of } \\
\text { change and progression in the health services. }\end{array}$ & 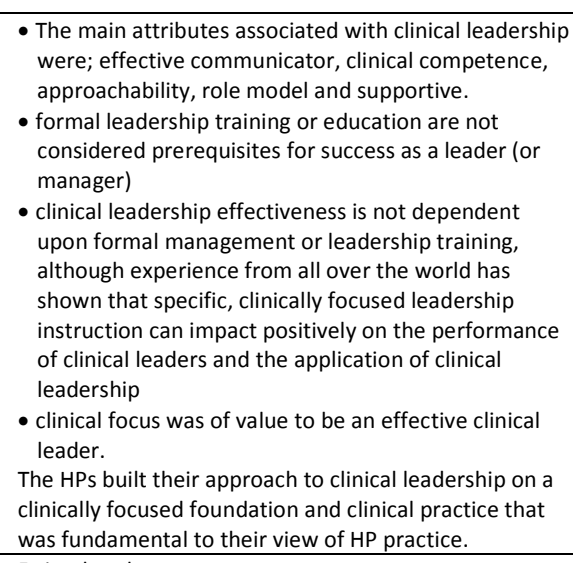 & $\begin{array}{l}\text { - linical leaders were perceived as having an impact on how clinical care } \\
\text { is delivered, staff support and leading change and service } \\
\text {. mprovement. }\end{array}$ & \begin{tabular}{|l}
-Staff \\
Team
\end{tabular} & \\
\hline & $F 19$ & $\begin{array}{l}\text { Best, A., Greenhalgh, T., Lewis, } \\
\text { S.,. Laul, J.E, , arroll, S,, and Bitz, } \\
\text { J. (2012) Large-System }\end{array}$ & \begin{tabular}{|l} 
Peer review journal \\
Realist review
\end{tabular} & & $\begin{array}{l}\text { Need for evidence base that addresses issues of } \\
\text { complexty and context for large system } \\
\text { transformation. }\end{array}$ & $\begin{array}{l}5 \text { simple rules: } \\
\text { //mc.manuscriptcentral.com/lihs }\end{array}$ & - Large system change & - Organisaton & \\
\hline
\end{tabular}




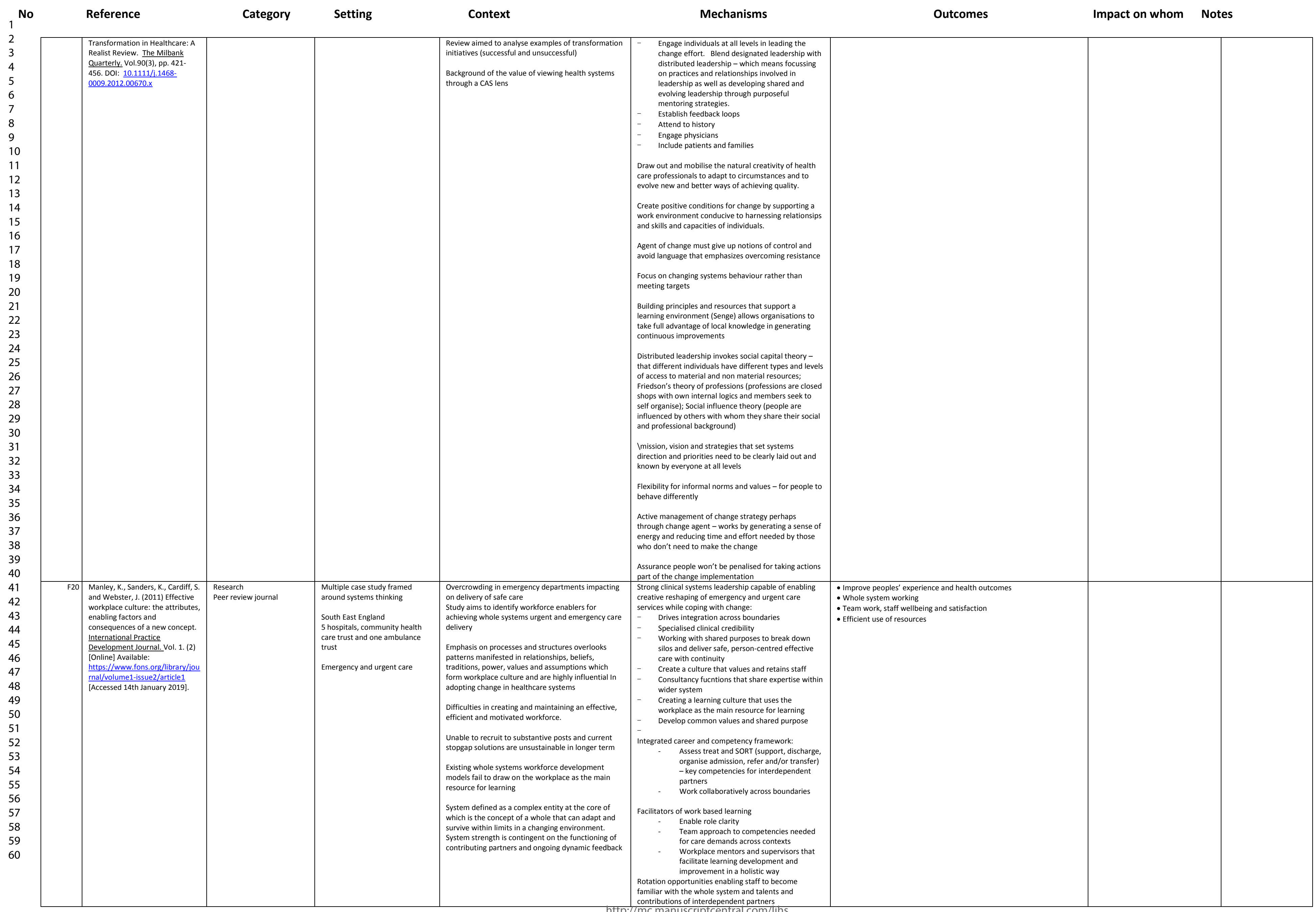




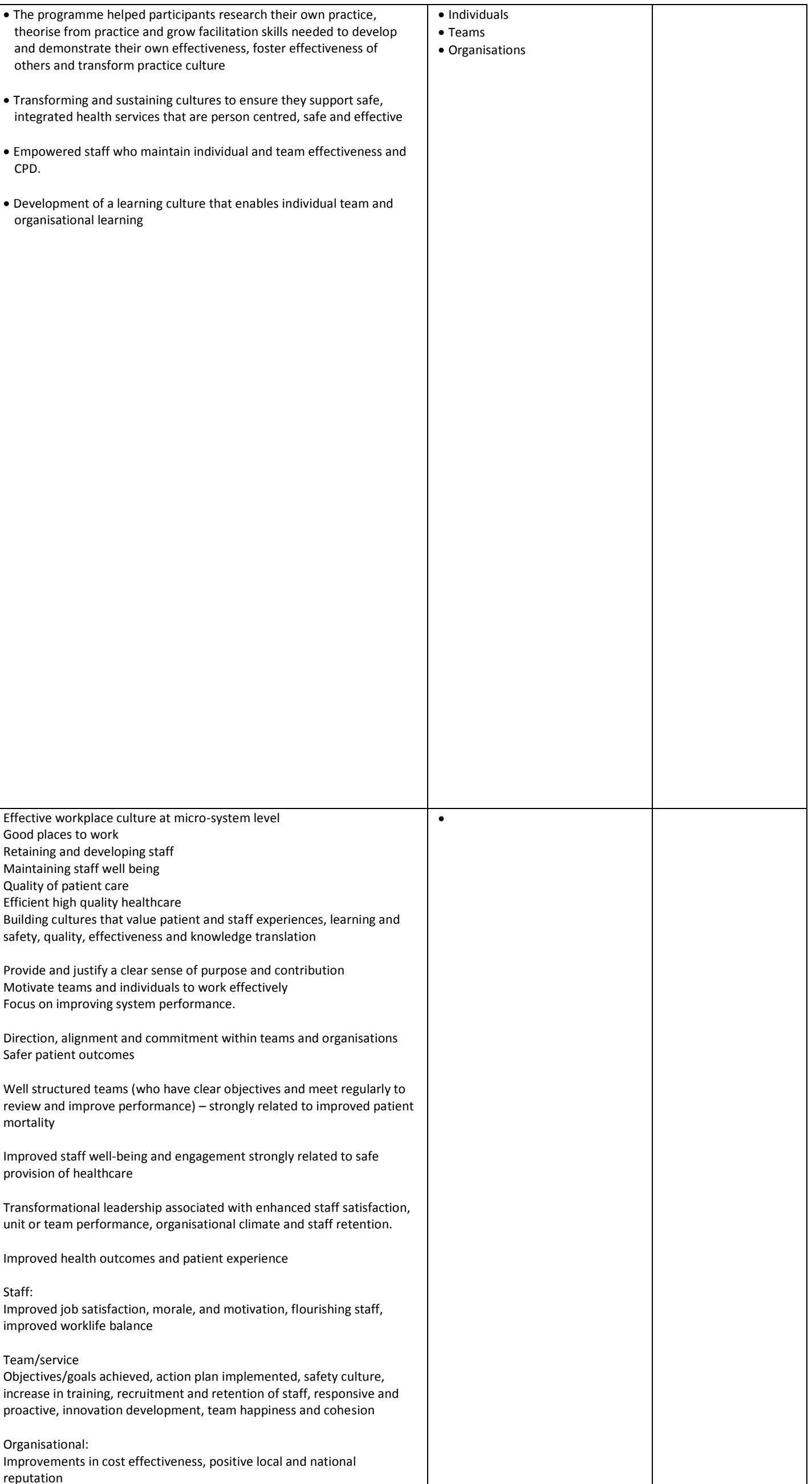




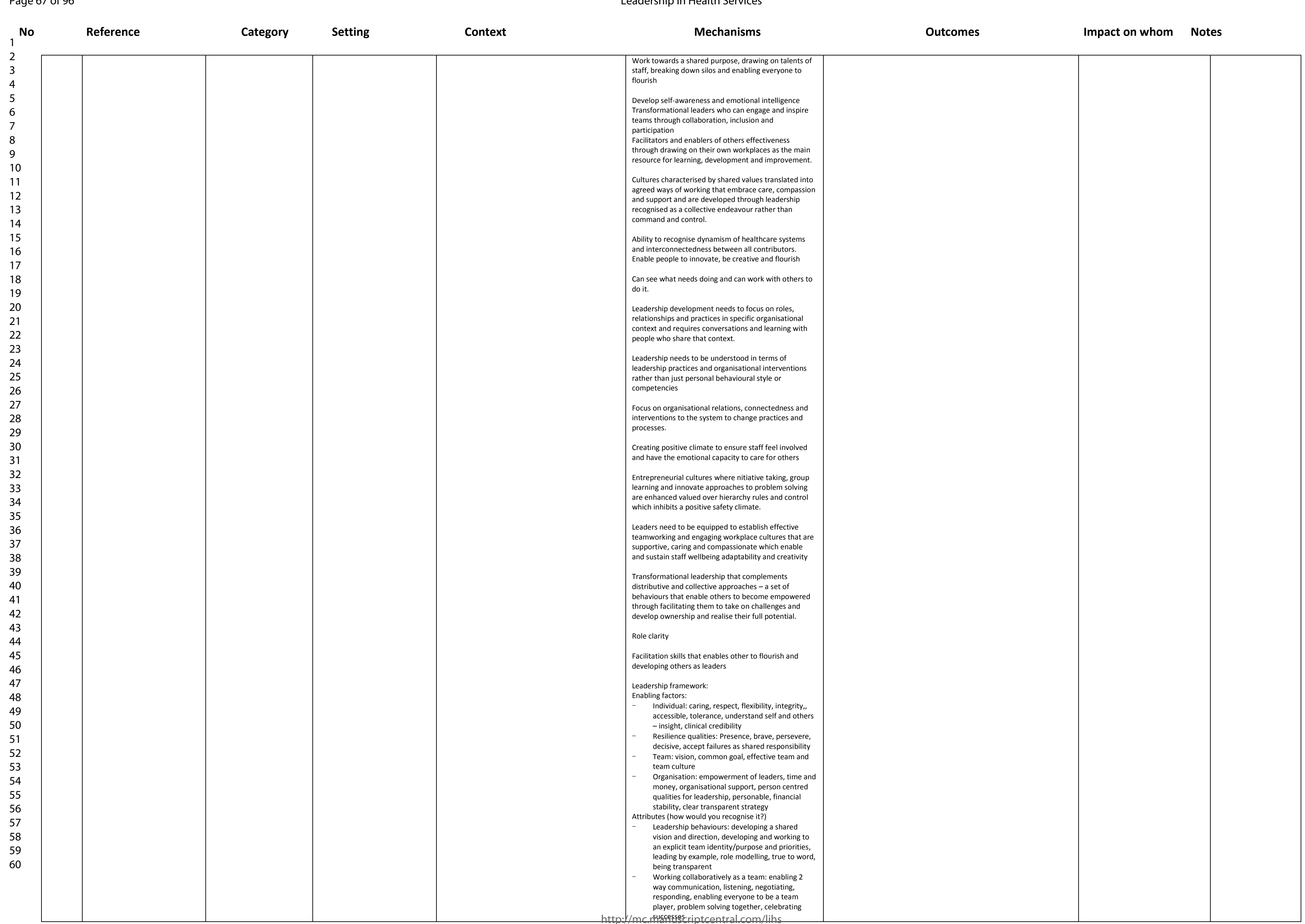




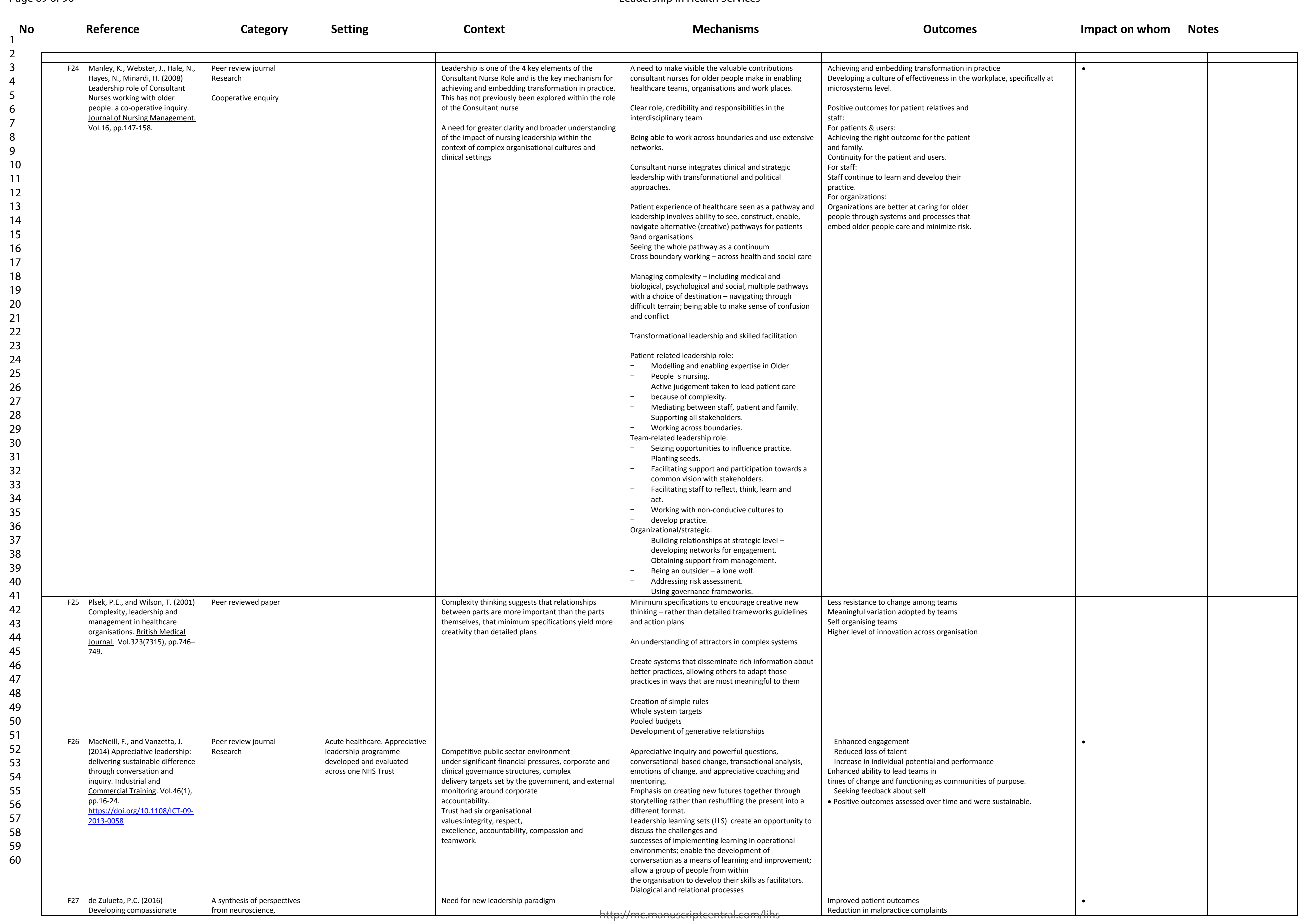




\begin{tabular}{|c|c|c|}
\hline $\begin{array}{l}\text { leadership in health care: an } \\
\text { integrative review, Journal of } \\
\text { Healthcare Leadership, Vol.8, } \\
\text { pp.1-10 }\end{array}$ & $\begin{array}{l}\text { psychology, and complexity } \\
\text { science with modern } \\
\text { leadership and } \\
\text { organizational theories }\end{array}$ & 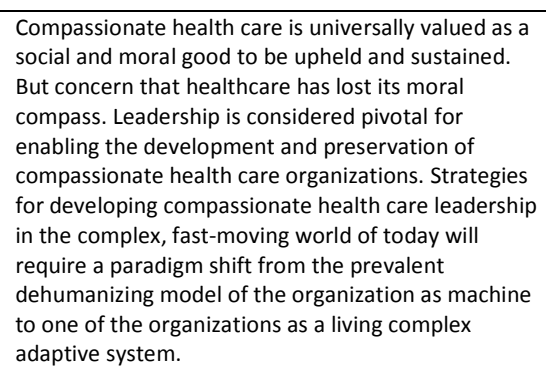 \\
\hline
\end{tabular}

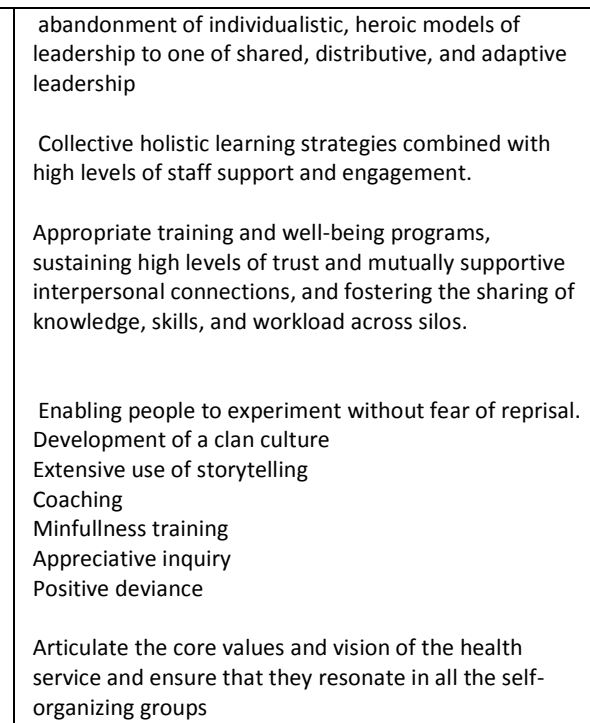
service and ensure that they resonate in all the self.

Tasks and relational care need to be integrated into a

Creating space for real dialog between patients,
clinicians, and managers, so that togetther they can clinicians, and managers, so that together they can
cocreate ways to flourish in the context of illness and cocreate
dying.

Practicing self compassion Modeling and harnessing of positive adaptive
responses to hallenges

Foster a culture of learning and openness

Relational transparency Learning the art of humble inquiry Democratizing work Listening to all the relevant voices
Focus on develoning teams that

Key processes: Caring conversations, flexible person centred risk
taking knowing me knowing you feedback involving,valuing and transparaency, creating spaces

Relationship centred model
Valuins

Valuing emotiona support
Recognsisong skilled facilitation required to foster
Athos

cultures of finquiry-
Action learning sets

Share positive
care practices and the processes that ente

care practices and the processses that enable
these to happen in m more systematic way

across organisations
Implementation of the Nuka model -Calculated risk-

taking innovation and creativty on the part of

taking innoverito
employees
Leadership

Leadership drives quick change while being conscious
of the potential for work fativiue in memployess $5 C$ F strives to grow leadership from within by mentoring

Tight alignment across all aspects of organisation All corporate, division, work unit, and individual goals and points": shared ressonsibility commitssonts 3 "key and family wellness.

leadership works to maximize individual employee skill while encouraging personal relationships within all re Employees are encouraged to take ownership of the
organization and are given power in decision-making. Leadership is also committed to building and organization, as well as a data system to measure

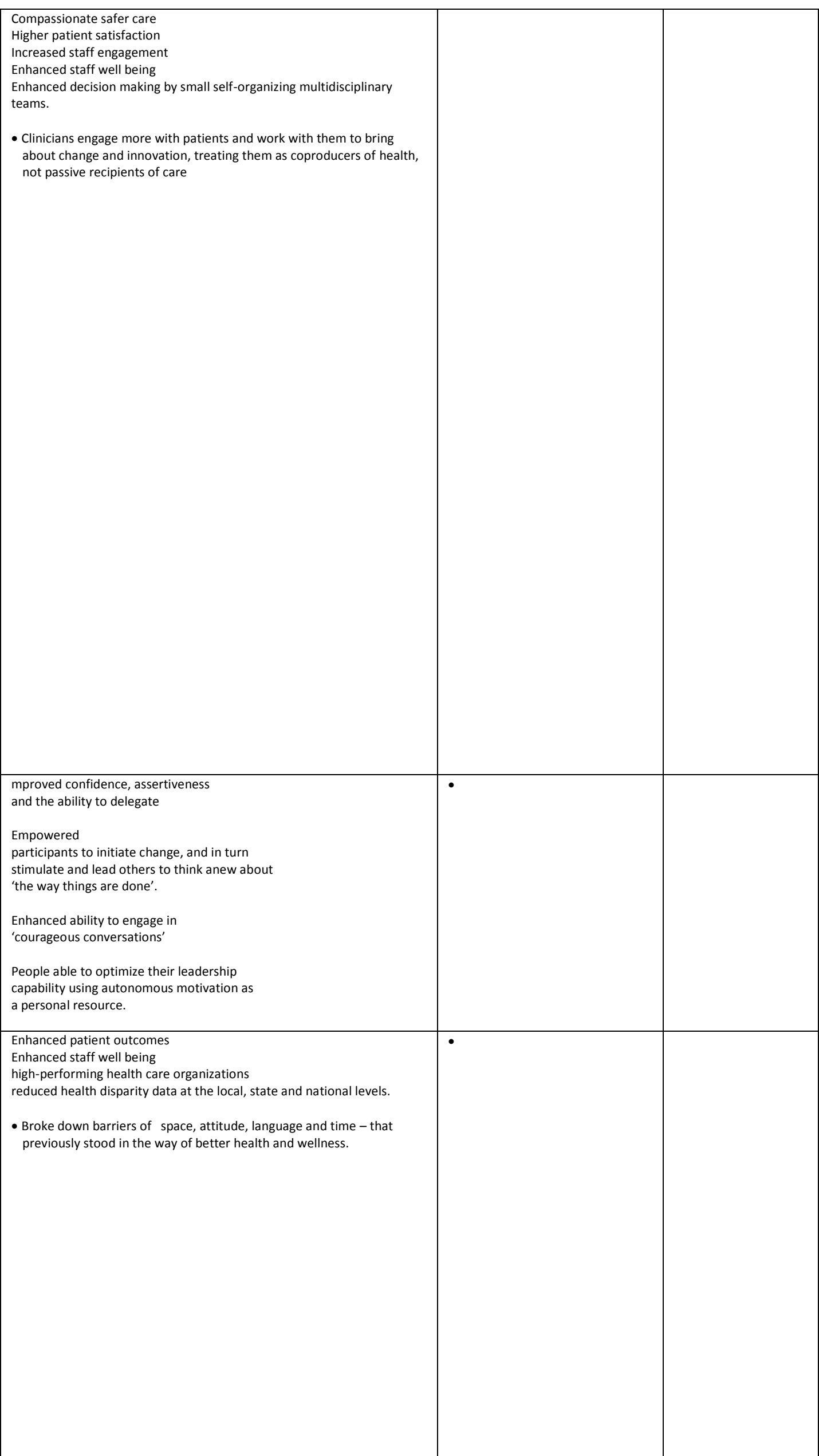




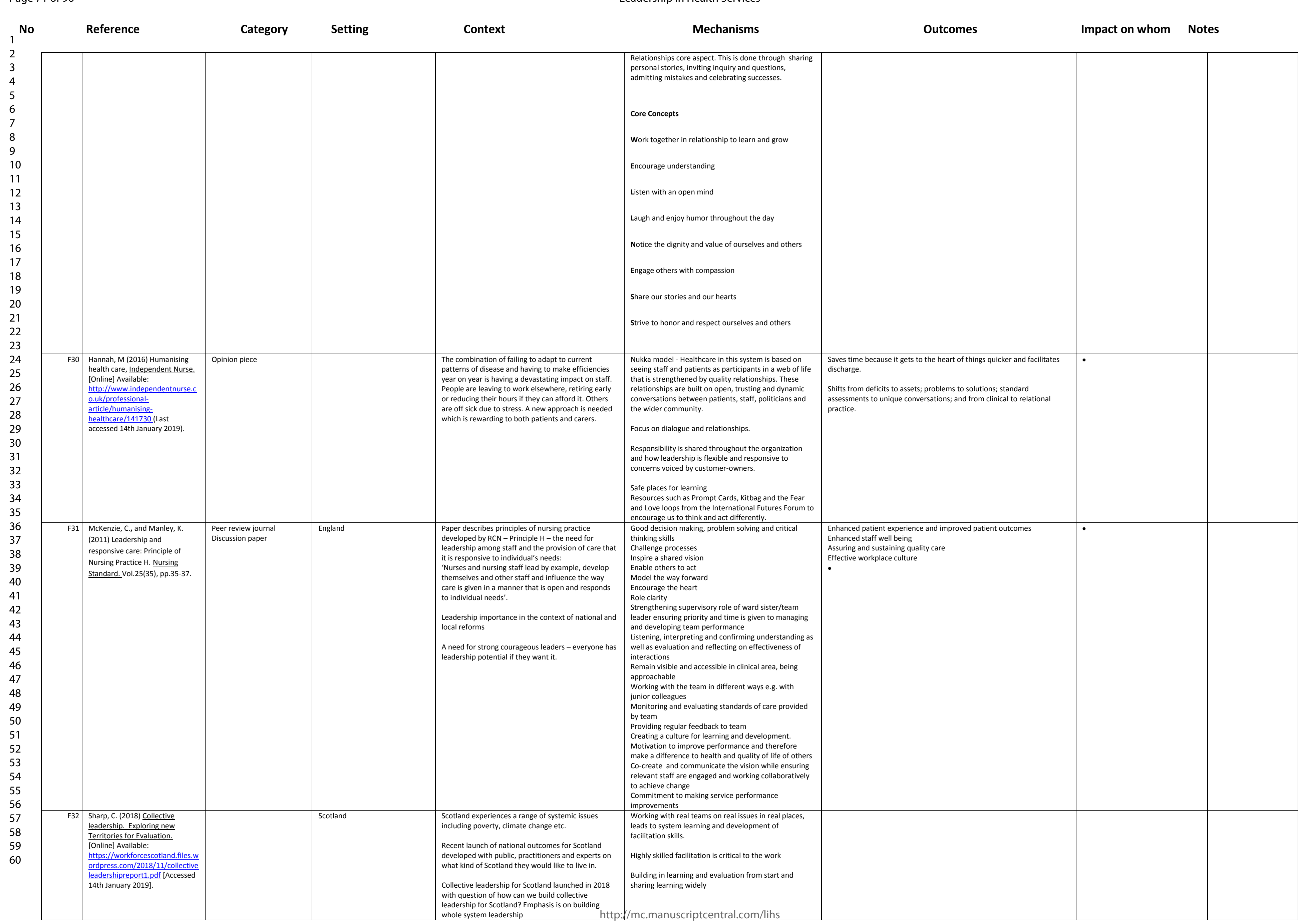




\begin{tabular}{|c|c|c|c|c|c|}
\hline${ }_{1}^{\text {No }}$ & Reference & Category & Setting & Context & Mechanisms \\
\hline 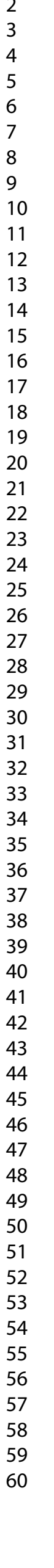 & & & & $\begin{array}{l}\text { Builds on previous work by workforce Scotland, } \\
\text { looking at systemic issues of wider public } \\
\text { transformation } \\
\text { complexity is generated by the services, } \\
\text { organisational } \\
\text { systems and relationships amongst them and from } \\
\text { both those who work in services and people } \\
\text { who are intended to benefit. } \\
\text { Greater acknowledgement of complexity in Scottand } \\
\text { and UK policy }\end{array}$ & 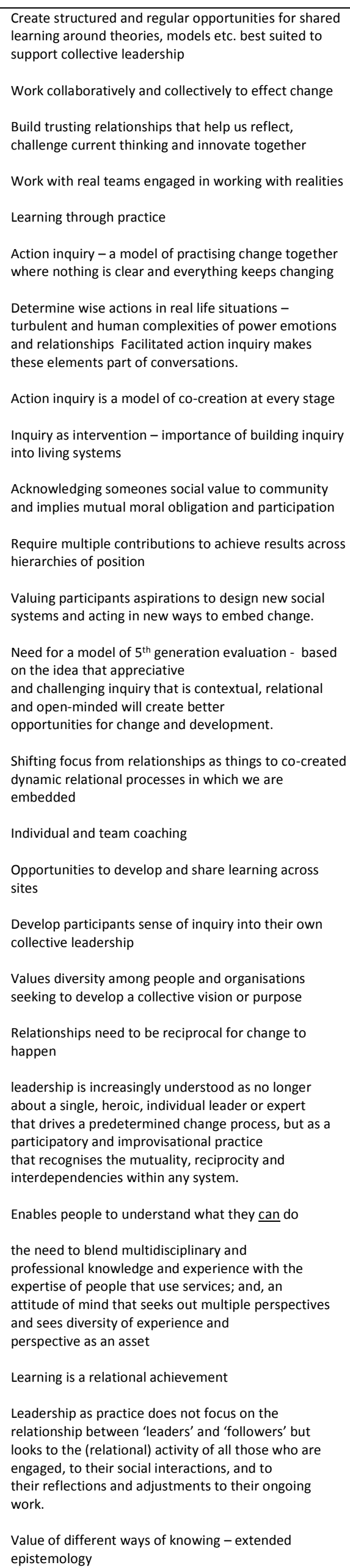 \\
\hline
\end{tabular}


Page 73 of 96

Leadership in Health Services

No
1
2
3
4
5
6
7
8
9
10
11
12
13
14
15
16
17
18
19
20
21
22
23
24
25
26
27
28
29
30
31
32
33
34
35
36
37
38
39
40
41
42
43
44
45
46
47
48
49
50
51
52
53
54
55
56
57
58
59
60

Reference

Category

Setting

Context

Mechanisms

Outcomes

Impact on whom Notes

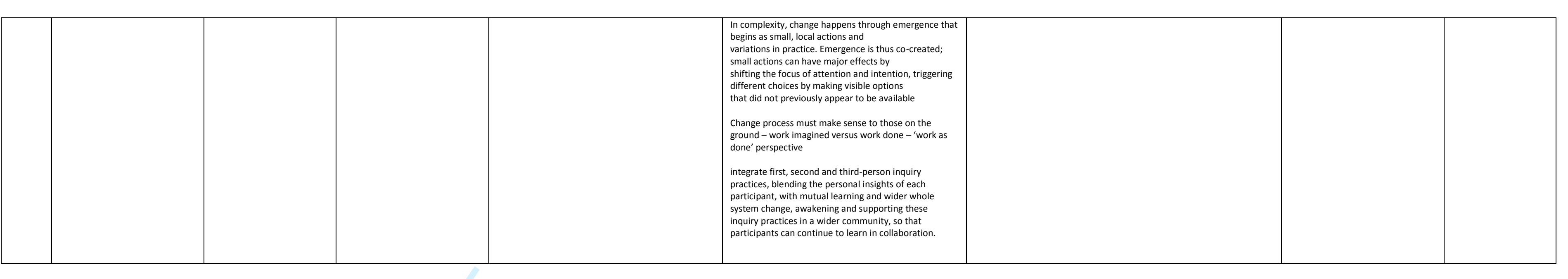




\begin{tabular}{|c|c|c|c|}
\hline \multicolumn{4}{|c|}{$\begin{array}{l}\text { Supplemental Document: The CMO Relationships informing each of the three tentative programme theories derived from } \\
\text { interrogating the literature and workshop dialogue }\end{array}$} \\
\hline WHAT WORKS (CONTEXT) & WHY IT WORKS (MECHANISMS) & $\begin{array}{l}\text { INTERMEDIATE OUTCOME } \\
\text { FOR WHOM }\end{array}$ & $\begin{array}{c}\text { ULTIMATE OUTCOME FOR } \\
\text { WHOM }\end{array}$ \\
\hline \multicolumn{4}{|c|}{ CMO relationships informing tentative Programme Theory 1: Authentic Relationships } \\
\hline $\begin{array}{l}\text { Contexts that focus on developing } \\
\text { NMAHPs as leaders who can build \& } \\
\text { nurture authentic, caring \& successful } \\
\text { relationships with individuals, those } \\
\text { important to them, staff and } \\
\text { stakeholders [C1] }\end{array}$ & $\begin{array}{l}\text { - Facilitate caring/compassionate civil conversations, } \\
\text { caring reflections and practices using different } \\
\text { opportunities and powerful inquiry questions for } \\
\text { conversation based change [M1,M5] } \\
\text { - Enables authentic presence and builds ethical } \\
\text { trusting relationships where people feel safe to } \\
\text { speak up [M2] } \\
\text { - } \text { Enables self \& situational awareness in self and } \\
\text { others through self-assessment, inquiry, self- } \\
\text { motivation, self-compassion, self-reflection for } \\
\text { learning, role clarity [M6] } \\
\text { - } \quad \text { Emotions are valued and used to connect [M4] } \\
\text { developed and nurtured in others [M3] } \\
\text { - Saves time } \\
\text { Time is saved because good relationships gets to the } \\
\text { heart of things quicker [040] }\end{array}$ & 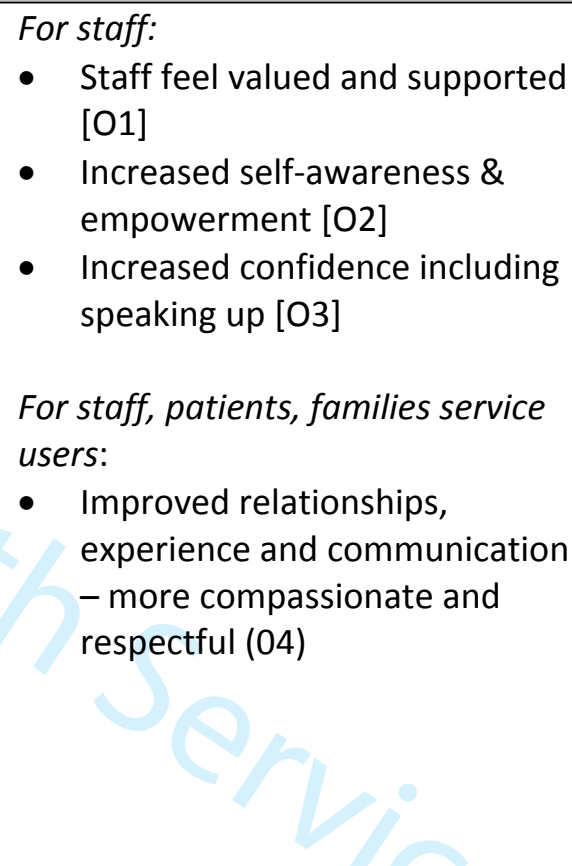 & $\begin{array}{l}\text { FOR INDIVIDUAL STAFF: } \\
\text { - Improved staff wellbeing, } \\
\text { reduced stress \& } \\
\text { emotional exhaustion [05] } \\
\text { - Improved staff morale and } \\
\text { satisfaction [06] } \\
\text { FOR TEAMS: } \\
\text { - Improved leadership - } \\
\text { compassionate, inclusive, } \\
\text { credible recognised \& } \\
\text { valued by others [07] } \\
\text { - Healthy, safe } \\
\text { workplace/culture with } \\
\text { staff engagement [09] } \\
\text { Enhanced team } \\
\text { effectiveness \& learning } \\
\text { culture [08] }\end{array}$ \\
\hline
\end{tabular}




\section{CMO relationships informing tentative Programme Theory 2: Transformational leadership linked to collective leadership and social capital}

\section{Contexts that:}

Develop transformational behaviours towards collective leadership \& growing a network of relationships and human connections as resources with a shared vision [C2]

Have a positive organisational culture, a flattened, transparent and supportive Infrastructure that helps members actively interact [C3]

Invest in strategic mentors and skilled facilitators for organisation wide initiatives [C4]
- Build \& use social capital and human connections through collaborative relationships \& networks [M7]

- Focus on what matters [M25]

- Enable positive social behaviours around core values [M10]

- Provides vision (a picture of a better more worthwhile state) with staff and a sense of unity which engenders a sense of belonging/identity/empowerment [M8]

- Embeds shared vision in clear expectations, acting on shared priorities [M12]

- Model the way/values and act with moral courage [M11]

- Motivate and support people, enabling feedback and self-empowerment [M10.2]

- Challenge, stimulate thinking and supports people with informed risk taking [M10.1]

- Celebrate, praise and 'encourages the heart' [M10.3]

- Focus on learning using different approaches to enable action [M14]

- Use the workplace for learning, improving \& reflection - including learning from the patients experience [M15]

- Blend, draw on and implement different types of evidence (M16)
For staff:

- Individuals feel involved \& heard [010]

- Positive staff morale \& Job Satisfaction [012].

- Staff empowerment, commitment and wellbeing [011]

- Staff confidence, clinical, professional skills, attitudes, credibility, relationships and career goals [013].

- Staff reduced burnout, stress and exhaustion [014].

For teams:

- $\quad$ Strong team identity [013]

- Enhanced work engagement, empowered team context team context performance, creativity, innovation [016]

- Evidence implementation, best practice, innovation [017]

For organisation

- Recruitment, retention and stability [020].

- Successfully health care organisation \& performance with staff commitment to organisation [022]

\section{PATIENTS \& FAMILIES:}

- Improved patients \& family outcomes [015]

TEAMS:

- Healthy teams [014]

- Culture and climate of safety and quality, improvement [015]

- Enhanced and strengthened leadership shared, distributive and adaptive [037]

\section{ORGANISATIONS}

- Improved quality \& safety, performance [019]

- Improved services and health care delivery [021].

- Positive organisational outcomes \& learning culture [018] 


\begin{tabular}{|c|c|c|c|}
\hline & & $\begin{array}{l}\text { Social capital for } \\
\text { organisational/systems change } \\
{[041]}\end{array}$ & \\
\hline \multicolumn{4}{|c|}{ CMO relationships informing tentative Programme Theory 3: Providing everyone a voice in complex and changing contexts. } \\
\hline $\begin{array}{l}\text { Contexts with: } \\
\text { A commitment to everyone having a } \\
\text { voice to support decision-making, } \\
\text { learning and co-creation of services in } \\
\text { partnership within increasing } \\
\text { complexity across systems [C5] } \\
\text { Engagement of all partners \& } \\
\text { development of interdisciplinary } \\
\text { services for a shared vision [C6] } \\
\text { Support by leaders to develop personal, } \\
\text { team and organisational effectiveness } \\
\text { [C7] } \\
\text { Draw on new models and roles to } \\
\text { support integration [C9] } \\
\text { Leaders who are credible, competent, } \\
\text { authentic and visible [M13] } \\
\text { Leadership values, skills and attributes } \\
\text { that embrace [C8]: } \\
\text { - Purpose and shared values } \\
\text { - Personal and professional skills } \\
\text { - Personal attributes } \\
\text { - Ethical/moral attributes: } \\
\text { - Communication skills }\end{array}$ & $\begin{array}{l}\text { - Engages all in the co-creation of a shared vision, } \\
\text { ways of } \\
\text { working and adaption to changing contexts actively } \\
\text { seeking out experiences of those using and providing } \\
\text { services [M18] } \\
\text { Bring people together, creates and sustains teams } \\
\text { [M24] } \\
\text { - Creates a positive culture /milieu that enhances } \\
\text { commitment through participation and draws on } \\
\text { multiple perspectives and talents for change [M19] } \\
\text { - Develops an appreciative learning culture that } \\
\text { includes safe reflective spaces for collective learning } \\
\text { [M20] } \\
\text { - Creates and supports formal and informal learning } \\
\text { and improvement opportunities using holistic } \\
\text { facilitation [M21] } \\
\text { - Enables curiosity, creativity, challenge, experiment, } \\
\text { learning and feedback in the moment [M22] } \\
\text { - Works with a social construction of leadership - } \\
\text { therefore works with a social world and complexity } \\
\text { and understanding how systems work [M23] }\end{array}$ & $\begin{array}{l}\text { Individuals (incl service users) } \\
\text { - } \quad \text { Feel valued [O25] } \\
\text { For staff } \\
\text { - } \quad \text { Clinicians engage/co-create with } \\
\text { patients to bring about change \& } \\
\text { innovation as co-production } \\
\text { [O39] } \\
\text { - } \quad \text { Enhanced critical thinking, } \\
\text { creativity, improvement and } \\
\text { inquiry skills [O27] } \\
\text { - } \quad \text { Role clarity, autonomy \& shared } \\
\text { accountability [O28] } \\
\text { - Improved self-esteem, hope, } \\
\text { empowerment; stress reduction } \\
\text { [O26] } \\
\text { Organisation } \\
\text { - Decreased sickness \& turnover } \\
\text { [O33] } \\
\text { Enhanced visibility of community } \\
\text { nursing/nursing } \\
\text { Society } \\
\text { - Enhanced citizen behaviours, } \\
\text { social entrepreneurship and } \\
\text { advocacy [O36]. } \\
\text { Enhances organisational citizen } \\
\text { behaviour }\end{array}$ & $\begin{array}{l}\text { For staff; } \\
\text { - Increased motivation \& job } \\
\text { satisfaction [O29] } \\
\text { - } \quad \text { Flourishing staff and talent } \\
\text { retention \& management } \\
\text { [O38] } \\
\text { PATIENTS: } \\
\text { - Improved patient } \\
\text { outcomes [O30] } \\
\text { TEAMS } \\
\text { - Enhanced teamwork - self } \\
\text { organising/high } \\
\text { performing teams [O31] } \\
\text { ORGANISATIONS } \\
\text { - Enhanced safety culture \& } \\
\text { culture of openness [034] } \\
\text { Improved alignment \& } \\
\text { delivery of service [O32] } \\
\text { Organisational } \\
\text { effectiveness excellence, } \\
\text { innovation \& increased } \\
\text { organisational loyalty that } \\
\text { is noticed [O35] }\end{array}$ \\
\hline
\end{tabular}

3 
\begin{tabular}{|l|l|l|}
\hline - Collaboration & $\bullet$ Social entrepreneurship \\
\hline
\end{tabular}

- Transformational leadership behaviours

- Related business and facilitation skills

- Access to resources and networks
- Working for the collective good

- Enhanced organisational advocacy

- Improved social capital

- Positive social exchange relationship
SYSTEMS

- Whole system working [037]

- Value for Money \& cost effectiveness [039]

SOCIETY:

- Enhanced citizen behaviours, social entrepreneurship and advocacy (036)

- Improved population health [038] 
Table I: Study Design

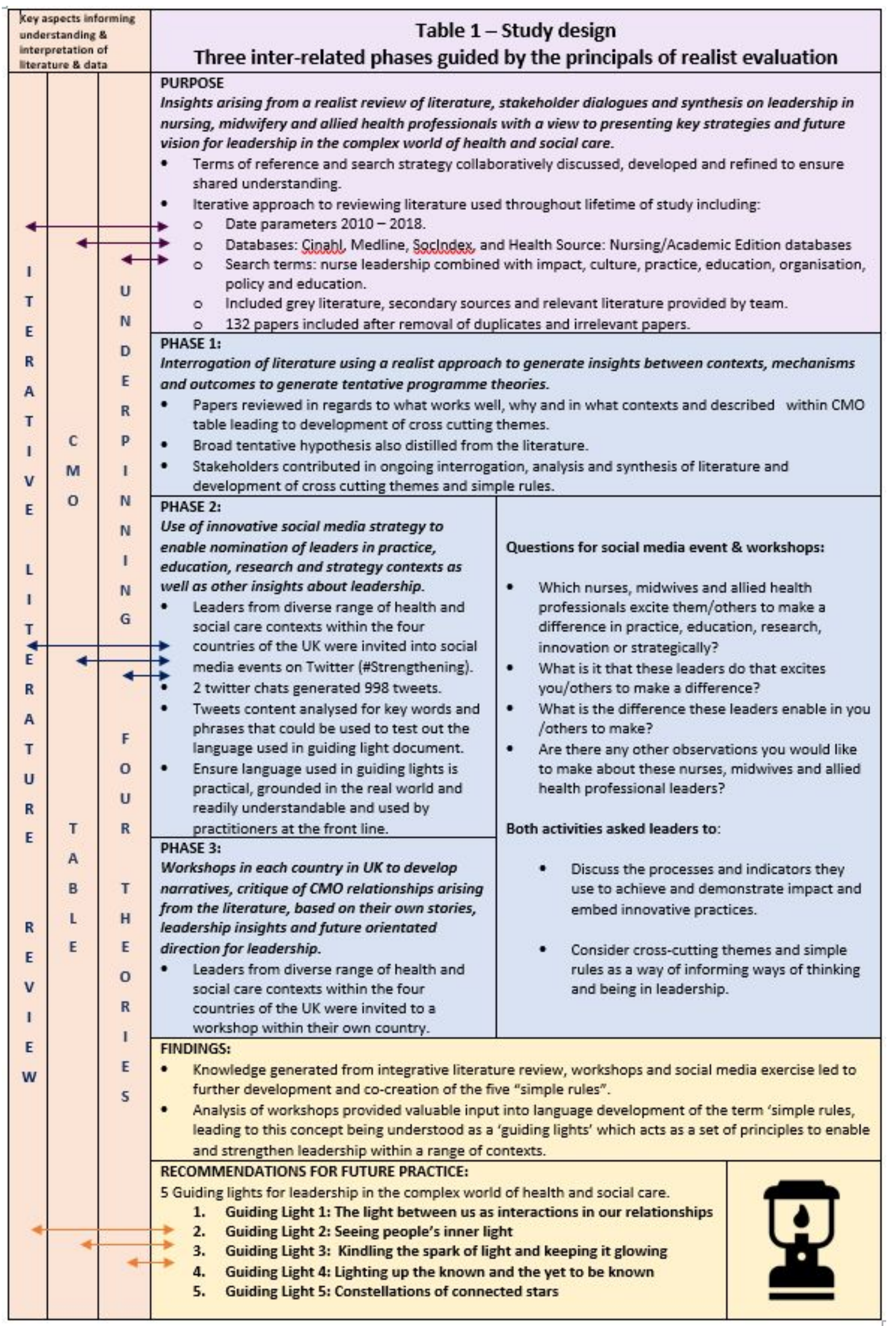


Table II: Example of Framework Constructed for first level analysis of the literature

\begin{tabular}{|c|c|c|c|c|c|c|c|c|}
\hline $\begin{array}{l}\text { Paper } \\
\text { Number }\end{array}$ & Reference & Category & Setting & Context & Mechanisms & Outcomes & $\begin{array}{c}\text { Impact on } \\
\text { Whom }\end{array}$ & Notes \\
\hline 1 & $\begin{array}{l}\text { Henderson, A. } \\
\text { (2013) } \\
\text { Processes to } \\
\text { Engage and } \\
\text { Motivate } \\
\text { Staff, Nursing } \\
\text { Management } \\
\text { Vol. 20(8), } \\
\text { pp.18-24. } \\
\text { Read 19.2.18 }\end{array}$ & $\begin{array}{l}\text { Peer review } \\
\text { journal } \\
\text { Research }\end{array}$ & $\begin{array}{l}\text { - Specialist } \\
\text { surgical unit } \\
\text { - Australia }\end{array}$ & $\begin{array}{l}\text { - 'poor working } \\
\text { relationships'. } \\
\text { - Manager } \\
\text { adopted } \\
\text { transformational } \\
\text { leadership } \\
\text { behaviours and } \\
\text { facilitated } \\
\text { activities with } \\
\text { practice } \\
\text { development }\end{array}$ & $\begin{array}{l}\text { - Transformational } \\
\text { leadership } \\
\text { techniques/behaviours } \\
\text { that focus on } \\
\text { feedback, learning and } \\
\text { improving quality } \\
\text { rather than task focus, } \\
\text { challenging the } \\
\text { tradition of 'how } \\
\text { things are done' to } \\
\text { bring about the } \\
\text { desired behaviours: } \\
\text { - Create a vision for } \\
\text { staff to follow. } \\
\text { Challenge existing } \\
\text { behaviours, } \\
\text { particularly } \\
\text { negative } \\
\text { interactions. } \\
\text { Encourage staff to } \\
\text { contribute to } \\
\text { decisions. } \\
\text { Support access to } \\
\text { clinical knowledge } \\
\text { and individual } \\
\text { skills } \\
\text { development. } \\
\text { Sustain efforts } \\
\text { through reward } \\
\text { and recognition of } \\
\text { desired } \\
\text { behaviours } \\
\text { Activities involved } \\
\text { coaching, } \\
\text { interactive }\end{array}$ & $\begin{array}{l}\text { - Sinflo } \\
\text { (Support } \\
\text { instrument for } \\
\text { nurses } \\
\text { facilitating the } \\
\text { learning of } \\
\text { others) and } \\
\text { CLOCS } \\
\text { (Clinical } \\
\text { Learning } \\
\text { Organisation } \\
\text { Survey) } \\
\text { questionnaires } \\
\text { at beginning } \\
\text { of project and } \\
\text { 12 months } \\
\text { later. Results } \\
\text { showed an } \\
\text { improvement } \\
\text { in most areas } \\
\text { including } \\
\text { support, } \\
\text { culture and } \\
\text { facilitating } \\
\text { others } \\
\text { learning. } \\
\text { - Field notes of } \\
\text { local } \\
\text { successes and } \\
\text { informal } \\
\text { observations } \\
\text { also } \\
\text { documented a } \\
\text { change in } \\
\text { various areas }\end{array}$ & $\begin{array}{l}\text { - Nurses } \\
\text { considered } \\
\text { work was } \\
\text { more } \\
\text { acknowledged } \\
\text { - Improved } \\
\text { performance } \\
\text { impact on } \\
\text { patients and } \\
\text { organisation. }\end{array}$ & $\begin{array}{l}\text { - Reference to } \\
\text { Magnet } \\
\text { Recognition } \\
\text { programme- } \\
\text { recognises } \\
\text { organisations } \\
\text { for high } \\
\text { quality care, } \\
\text { nursing } \\
\text { excellence } \\
\text { and } \\
\text { innovations } \\
\text { on nursing } \\
\text { practice } \\
\text { (American } \\
\text { Nurses } \\
\text { Credentialing } \\
\text { Center, } \\
\text { 2013). } \\
\text { - ? field notes } \\
\text { of local } \\
\text { successes } \\
\text { indicating } \\
\text { changes- } \\
\text { how do we } \\
\text { know these } \\
\text { weren't } \\
\text { happening } \\
\text { before? }\end{array}$ \\
\hline
\end{tabular}




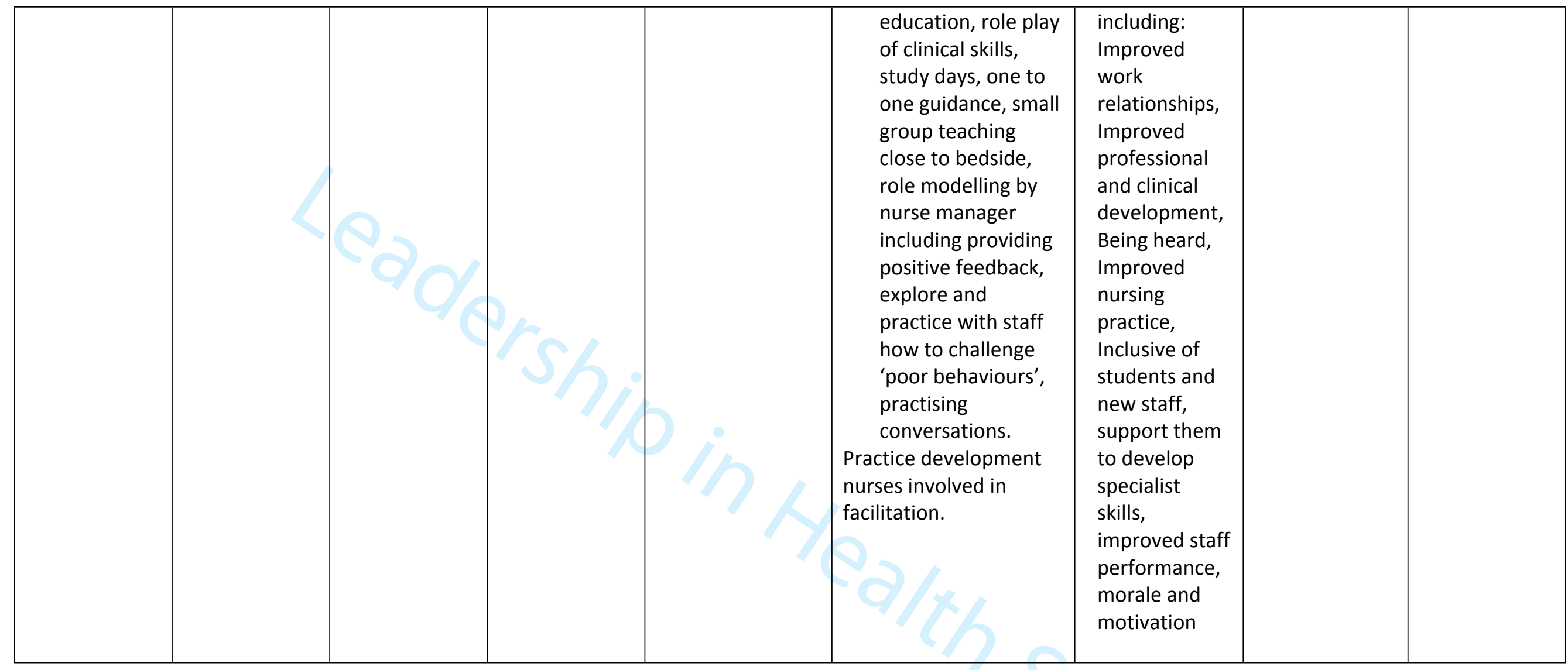


Table III Illustration of second level analysis CMO relationships in relation to NMAHP leadership derived from interrogating the literature for cross cutting theme Authentic Relationships and Connections

\begin{tabular}{|c|c|c|}
\hline WHAT WORKS (CONTEXT) & WHY IT WORKS (MECHANISMS) & OUTCOME \& FOR WHOM \\
\hline 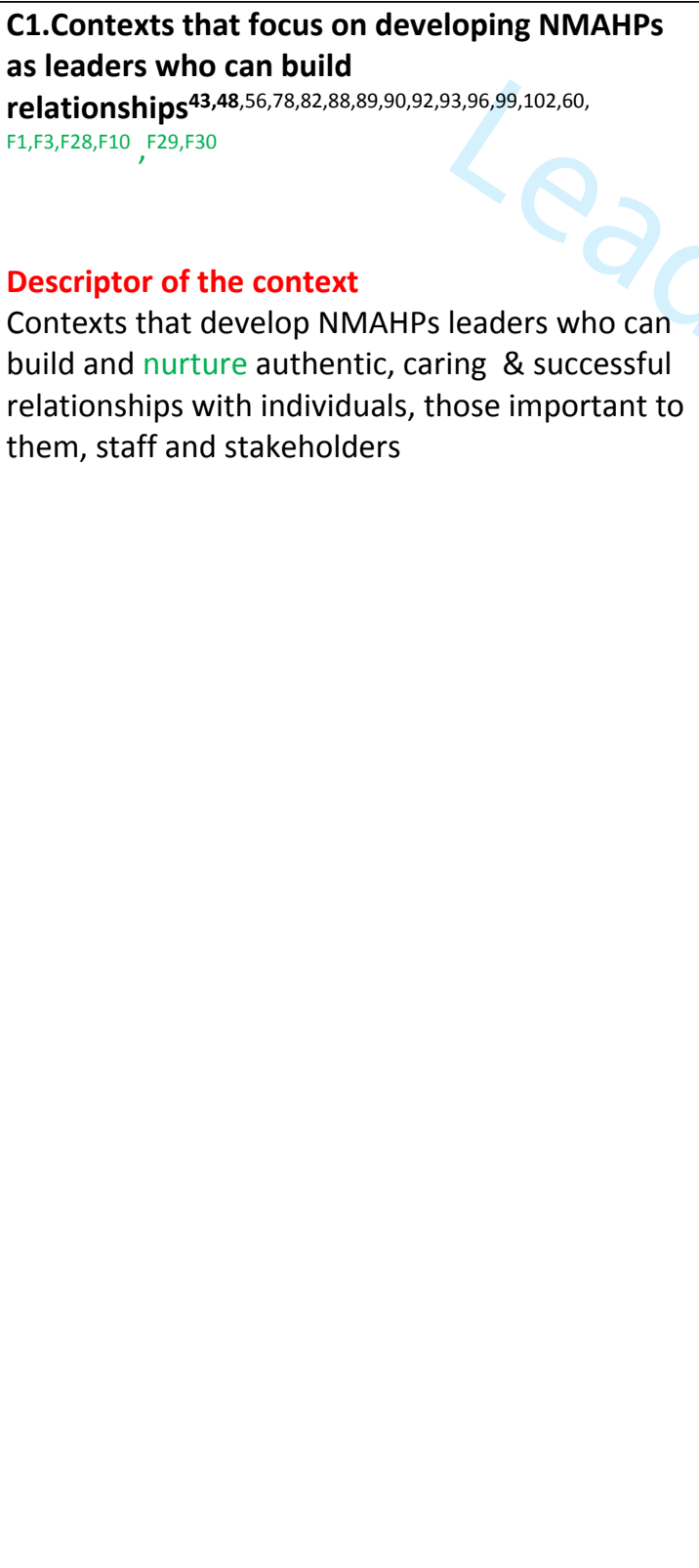 & 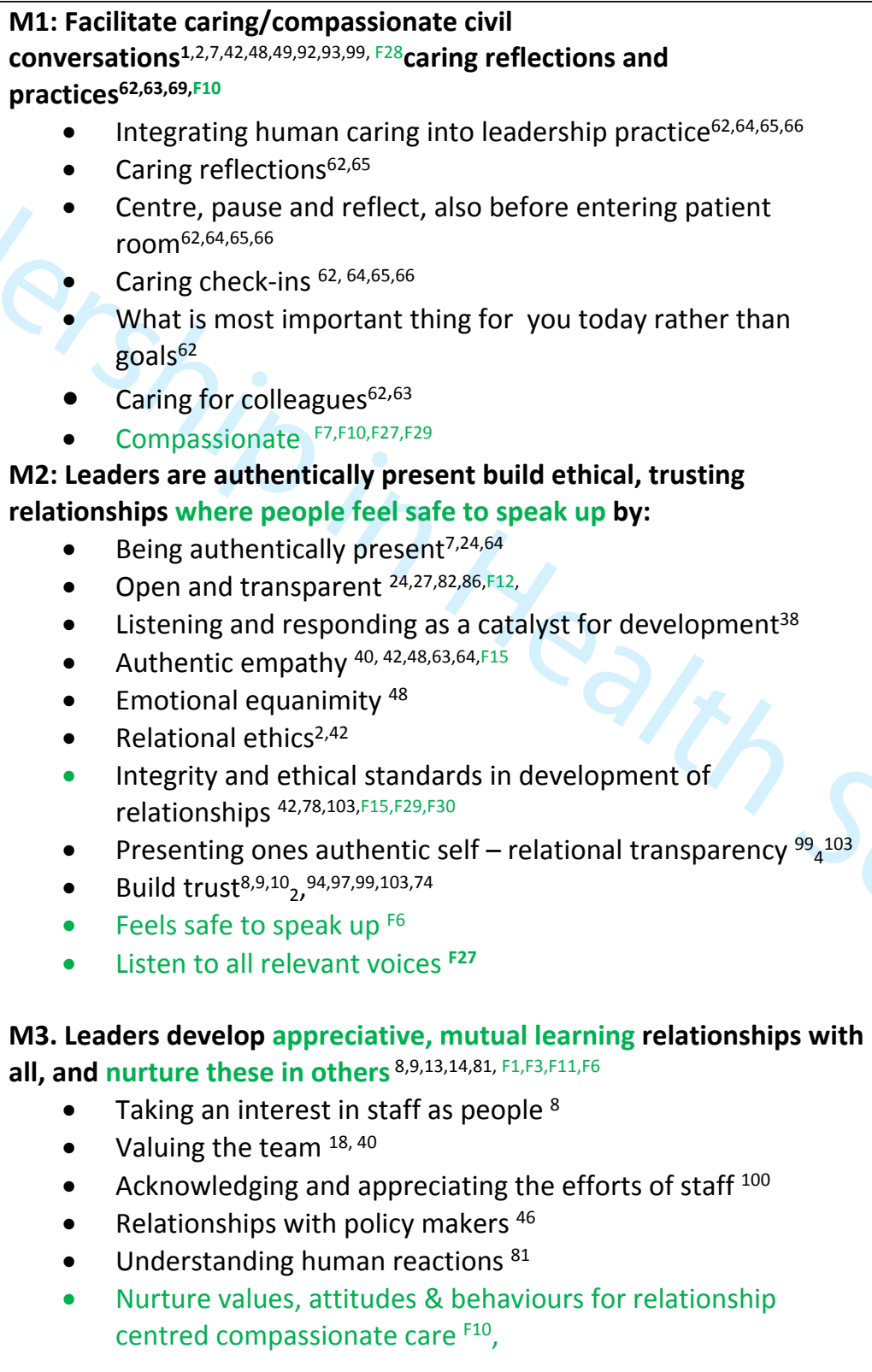 & 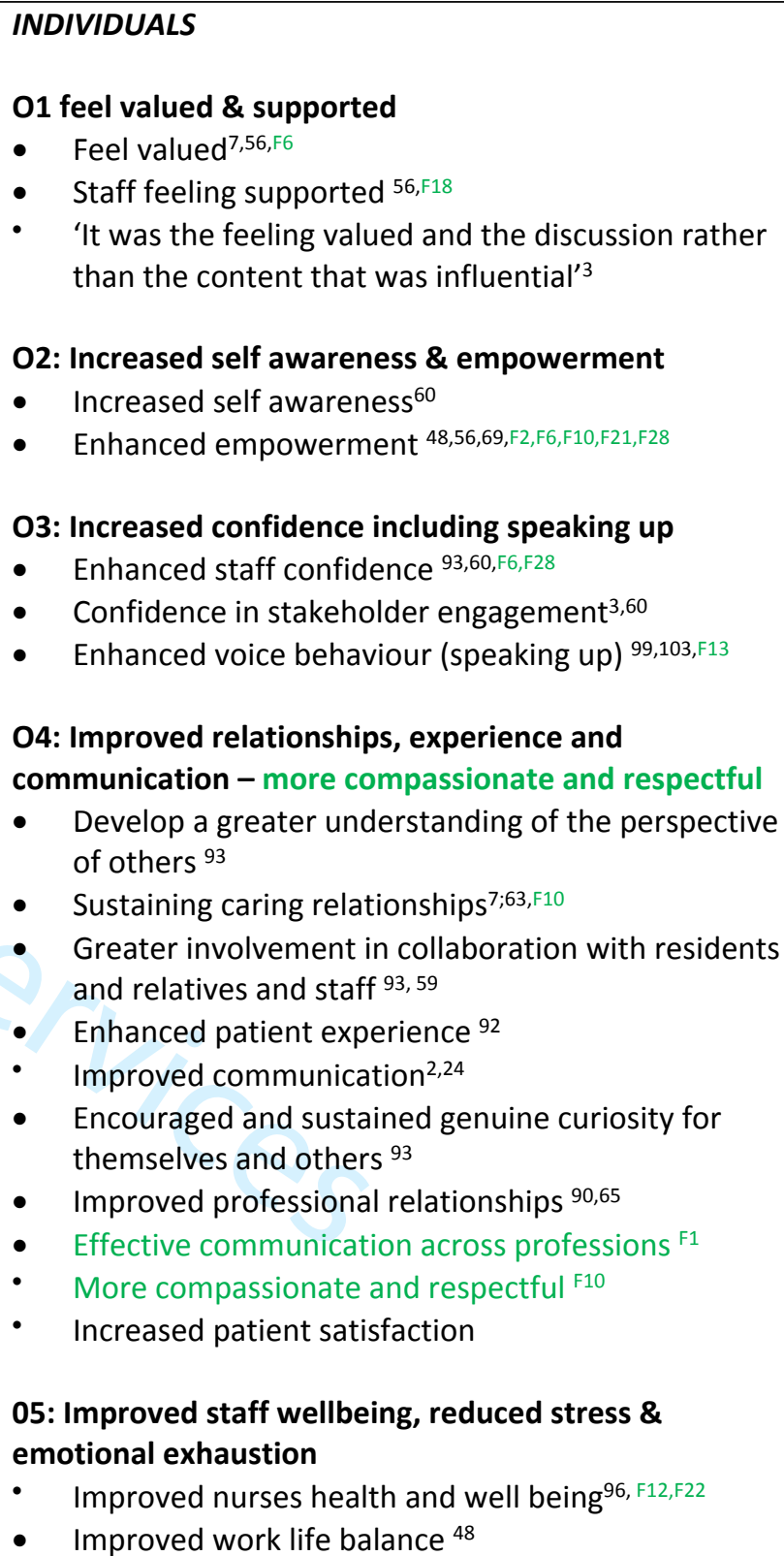 \\
\hline
\end{tabular}


Build mutual learning relationships ${ }^{\text {F22 }}$

- Build relationships with all F23

- Focus shifts from deficits to assets ${ }^{\mathrm{F}} \mathrm{O}$

\section{M4: Leaders connect emotions}

- Emotional intelligence $2,27,29,31,43,48,51,89,95,8,43,50,51, F 12$

- Valuing emotionality $93,63, F 28$

- Build an emotional \& rationale case for change ${ }^{16,44,47,75}$

- Connect emotionally $\mathrm{F}^{10}$

M5: Leaders use different opportunities, use powerful inquiry questions for conversation- based change

- $\quad$ e.g Daily huddles ${ }^{7,44}$; Group discussions ${ }^{3,20,22,23,24,29,36}$

- Debriefing ${ }^{2}$

- Dialogic conversations $24,48, F 26$

- Value non-hierarchical communication 24

- Story telling F27,F28,F29

- Have courageous conversations $\mathrm{F} 10, \mathrm{~F} 28, \mathrm{f3} 1$

- Use powerful inquiry questions for conversation based change ${ }^{\mathrm{F} 22, \mathrm{~F} 26, \mathrm{~F} 29}$

- $\quad$ Positive deviance,, 527

M6: Leaders enable self \& situational awareness in self and others through self-assessment, inquiry, self-motivation, self-compassion, self-reflection for learning, role clarity $2,3,5,21,27,43,48,50,89,93,95,99$ In Self

- Developing and practising self care ${ }^{7,63}$

- Self-regulation ${ }^{89}$

- Knowing more about me 93,F26

- Deeper understanding of ones strengths and weaknesses 99

- Self-motivation $48, \mathrm{~F} 12$

- Continuous self-reflection and learning 48,54,56,60,65, F12

- Self-assessment of role clarity and skill set of transformational leaders 97

- Self-compassion F23,F27

- An open inquiring mind F12

\section{In others}

- Facilitating embodied knowing 2, F12

- Openness to spirituality ${ }^{7}$

- Facilitate personal identification by connecting with the selfconcept of followers ${ }^{103}$

- Wellness and independence ${ }^{23}{ }_{5}$

- Reduced emotional exhaustion ${ }^{48}$

- Reduction in stress ${ }^{93}$

\section{6: Improved staff morale \& satisfaction}

- Intention to stay ${ }^{99}$

- Increased job satisfaction $93,99,103, F 6$

- Increased staff satisfaction $23,24,38,48,82,96,99,75$

- Improved staff morale ${ }^{93}$

07: Improved leadership - compassionate, inclusive, credible recognised \& valued by others

- Improved knowledge of effective leadership $3,30,60$

- Helped leaders to focus, prioritise and evaluate practice $^{58}$

- $\quad$ Freedom to make care decisions ${ }^{38}$

- Improved leadership $p^{3,30}$

- Ability to influence others ${ }^{8}$

- Compassionate, inclusive leadership F7,F13

- Credibility, recognised and valued by others ${ }^{\mathrm{F} 23}$

\section{TEAM (including service users and relatives)}

08: Enhanced team effectiveness \& learning culture

- Enhanced team effectiveness 99, F1, F21

- Building of shared mental models within team 99

- Perceptions unit is changing for the better ${ }^{7}$

- Effective decision making ${ }^{99}$

- Learning culture ${ }^{\mathrm{F} 21}$

- Improvement skills F7,F13

- Effective workplace culture at microsystems level ${ }^{221, F 22, F 24}$

- Ethos of continuous learning and improvement F10

09: Healthy, safe workplace/culture - staff engagement

- Safe positive workplace culture $21,24,89,96$

- Enhanced work environment ${ }^{48}$ characterised by resilience and innovation ${ }^{48}$

- Healthy workplace/working environments ${ }^{83,96}$

- Improved clinical environment ${ }^{90}$

- Staff engagement $56, \mathrm{~F} 7, \mathrm{~F} 13$, 


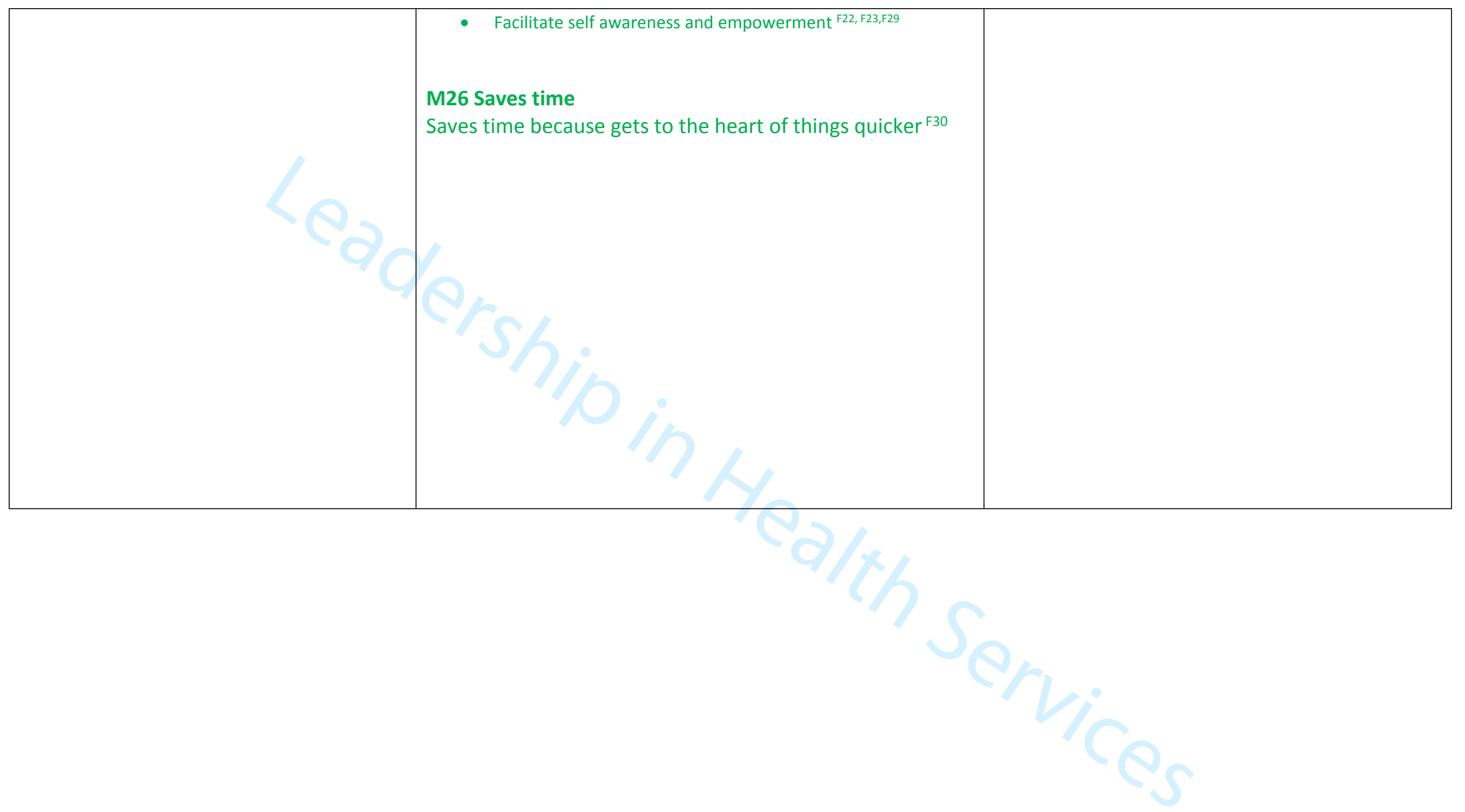


Table iV: Illustration of Cross Cutting Theme 1 Authentic Relationships and Connections further refined in preparation for presentation to workshop participants

\begin{tabular}{|c|c|c|c|}
\hline WHAT WORKS (CONTEXT) & WHY IT WORKS (MECHANISMS) & $\begin{array}{l}\text { INTERMEDIATE OUTCOME \& FOR } \\
\text { WHOM }\end{array}$ & $\begin{array}{l}\text { ULTIMATE OUTCOME \& FOR } \\
\text { WHOM }\end{array}$ \\
\hline $\begin{array}{l}\text { Contexts that focus on developing } \\
\text { NMAHPs as leaders who can build \& } \\
\text { nurture authentic, caring \& successful } \\
\text { relationships with individuals, those } \\
\text { important to them, staff and stakeholders } \\
\text { [C1] }\end{array}$ & $\begin{array}{l}\text { Facilitate caring/compassionate civil conversations, } \\
\text { caring reflections and practices using different } \\
\text { opportunities and powerful inquiry questions for } \\
\text { conversation based change [M1,M5] } \\
\text { Enables authentic presence and builds ethical } \\
\text { trusting relationships where people feel safe to } \\
\text { speak up [M2] } \\
\text { Enables self \& situational awareness in self and } \\
\text { others through self-assessment, inquiry, self- } \\
\text { motivation, self-compassion, self-reflection for } \\
\text { learning, role clarity [M6] } \\
\text { Emotions are valued and used to connect [M4] } \\
\text { Appreciative, mutual learning relationships are } \\
\text { developed and nurtured in others [M3] } \\
\text { Saves time } \\
\text { Time is saved because gets to the heart } \\
\text { of things quicker [040] }\end{array}$ & $\begin{array}{l}\text { FOR STAFF } \\
\text { - } \quad \text { Staff feel valued and supported [O1] } \\
\text { - Increased self awareness \& } \\
\text { empowerment [O2] } \\
\text { - Increased confidence including speaking } \\
\text { up [O3] } \\
\text { FOR STAFF, PATIENTS, FAMILIES SERVICE } \\
\text { USERS: } \\
\text { - Improved relationships, experience and } \\
\text { communication - more compassionate } \\
\text { and respectful (04) }\end{array}$ & $\begin{array}{l}\text { FOR INDIVIDUAL STAFF MEMBERS } \\
\text { - Improved staff wellbeing, reduced } \\
\text { stress \& emotional exhaustion } \\
\text { [O5] } \\
\text { - Improved staff morale and } \\
\text { satisfaction [06] } \\
\text { FOR TEAMS: } \\
\text { - Improved leadership - } \\
\text { compassionate, inclusive, credible } \\
\text { recognised \& valued by others } \\
\text { [07] } \\
\text { Healthy, safe workplace/culture } \\
\text { with staff engagement [09] } \\
\text { Enhanced team effectiveness \& } \\
\text { learning culture [O8] }\end{array}$ \\
\hline
\end{tabular}


Table V: Sample of comments derived from Twitter Chat to help inform development of Guiding Light 1

\begin{tabular}{|c|c|c|c|c|}
\hline GUIDING LIGHT & $\begin{array}{l}\text { LEADERSHIP ATTRIBUTES } \\
\text { identified as influential in } \\
\text { twitterchat -useful for } 360 \\
\text { (numbers in brackets indicate } \\
\text { twitter statement) }\end{array}$ & $\begin{array}{l}\text { IMPACT OF LEADERSHIP } \\
\text { EXPERIENCED by } \\
\text { participants in twitterchat } \\
\text { on them selves }\end{array}$ & $\begin{array}{l}\text { LEADERSHIP PROCESSES } \\
\text { perceived as infliuential by } \\
\text { participants } \\
\text { (numbers in brackets indicate } \\
\text { twitter statement) }\end{array}$ & $\begin{array}{l}\text { IMPACT OF LEADERSHIP } \\
\text { perceived by participants in } \\
\text { twittechat more generally } \\
\text { (numbers in brackets } \\
\text { indicate twitter statement) }\end{array}$ \\
\hline $\begin{array}{l}\text { Guiding Light 1: 'The Light } \\
\text { Between Us' } \\
\text { Working towards (OR BUILDING) } \\
\text { authentic caring relationships. } \\
\text { Building caring relationships with } \\
\text { all groups of people involved in } \\
\text { giving and receiving health and } \\
\text { social care that enable us to } \\
\text { reflect, stretch our current } \\
\text { thinking and innovate together } \\
\text { was a core finding from the } \\
\text { review and the data generated } \\
\text { through the workshops and social } \\
\text { media strand. }\end{array}$ & $\begin{array}{l}\text { APPROACHABLE,PERSONABLE, } \\
\text { COMPASSIONATE,GENEROUS } \\
\text { Personal approach (147) } \\
\text { Approachable (318) } \\
\text { Approachability and friendly } \\
\text { (383) } \\
\text { Approachable, caring, (518) } \\
\text { Compassionate (509) } \\
\text { Generosity(147) } \\
\text { Respect the respect they are } \\
\text { given (536) } \\
\text { Smile a lot (302) } \\
\text { SPARKLE, AUTHENTIC,RELAXED, } \\
\text { PASSIONATE } \\
\text { Sparkle with passion and } \\
\text { authenticity (58) } \\
\text { Being relaxed allows me to } \\
\text { make connections (383) } \\
\text { Passionate without aggression } \\
\text { (536) } \\
\text { OBSERVE, LISTEN,NON- } \\
\text { JUDGEMENTAL } \\
\text { Observe and listen (577) } \\
\text { Non-judgemental (509) } \\
\text { Don't gossip or join cliques } \\
\text { (509) } \\
\text { Ability to observe and listen, } \\
\text { (318) }\end{array}$ & $\begin{array}{l}\text { ENCOURAGED ME TO FOLLOW } \\
\text { PASSION } \\
\text { Encourage me to follow } \\
\text { passion(58) } \\
\text { Passion is infectious (137) } \\
\text { SHOWING YOU ARE REAL PERSON } \\
\text { Showing you are a real } \\
\text { person, having a friendly } \\
\text { attribute (343) } \\
\text { Took time with me, shared } \\
\text { their vulnerabilities with me, } \\
\text { co-created with me (95) } \\
\text { Admitting they have failed - } \\
\text { no-one is perfect (397) } \\
\text { Share own experiences (152) } \\
\text { Unselfish, share experiences, } \\
\text { highs and lows - importantly } \\
\text { including failure's (664) }\end{array}$ & $\begin{array}{l}\text { CONNECT IN A WAY THAT MAKES } \\
\text { EVERYONE FEEL SPECIAL } \\
\text { Modest yet gifted in ability to } \\
\text { make students feel } \\
\text { extraordinary special (761) } \\
\text { CONNECTS AUTHENTICALLY,TRUE } \\
\text { TO VALUES } \\
\text { Connect with each individual, } \\
\text { willing to be authentic, true to } \\
\text { their values and at same time } \\
\text { values the values of others } \\
\text { (770) } \\
\text { Happy to hear other peoples } \\
\text { thoughts and perspectives } \\
\text { (318) }\end{array}$ & \\
\hline
\end{tabular}




\section{Table VI: Summary of Participants in the National Workshops}

Participants from different contexts of nursing, midwifery and AHP contributing to national workshops

\begin{tabular}{|c|c|c|c|c|c|c|c|c|}
\hline Country & England & & Northern Ireland/Eire & & Scotland & & Wales & \\
\hline Nursing & Mental health x1 Researcher x2 & 3 & $\begin{array}{l}\text { Practice/services x6 Education } x 3 \\
\text { Research } x 2\end{array}$ & $\begin{array}{ll}63 \\
2\end{array}$ & $\begin{array}{l}\text { Practice/services Strategy } \\
\text { Education }\end{array}$ & $\begin{array}{l}31 \\
1\end{array}$ & $\begin{array}{l}\text { Practice Strategy } \\
\text { Research Education }\end{array}$ & $\begin{array}{lll}4 & 1 & 1 \\
3 & \end{array} \mid$ \\
\hline Midwifery & $\begin{array}{l}\text { Midwives } x 4 \text { Student } x 1 \\
\text { Researcher } x 1\end{array}$ & 6 & Practice $\times 1$ Research $x 1$ & 2 & & 0 & Practice & 1 \\
\hline AHP & $\begin{array}{l}\text { Practice/service } \times 5 \text { Education } x 1 \\
\text { Strategic } \times 2\end{array}$ & 8 & Practice $\times 3$ & 3 & $\begin{array}{l}\text { Dietician Physiotherapist } \\
\text { Education }\end{array}$ & $\begin{array}{l}11 \\
1\end{array}$ & $\begin{array}{l}\text { Paramedic Pharmacist } \\
\text { Other }\end{array}$ & 4 \\
\hline $\begin{array}{l}\text { Citizens through } \\
\text { U3A }\end{array}$ & & 2 & 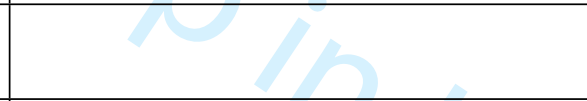 & 2 & & 2 & & \\
\hline Total & & 19 & +8 & 18 & & 10 & & 14 \\
\hline
\end{tabular}




\section{Table VII Initial Programme Theories and Guiding Lights}

\begin{tabular}{|l|l|}
\hline Initial Programme Theories & Five 'Simple Rules' \\
\hline 1) Authentic relationships and connections, & Guiding Light 1 \\
\hline 2) Transformational leadership linked to collective leadership and social capital & Guiding Light 2 Guiding Light 3 \\
\hline 3) Providing everyone a voice in complex and changing contexts. & Guiding Light 4 Guiding Light 5 \\
\hline
\end{tabular}




\section{Table VIIII The Guiding Lights of NMAHP Leadership}

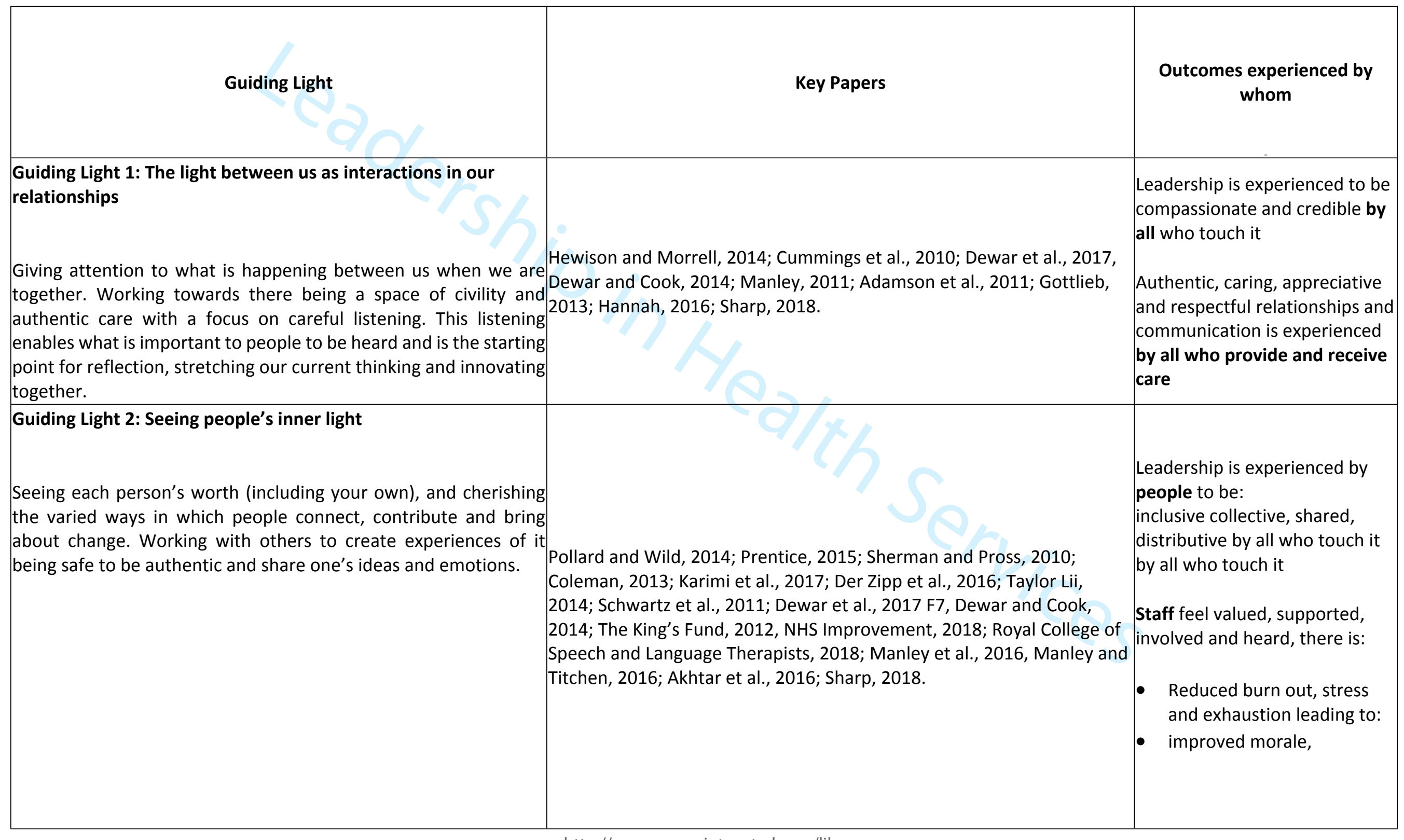




\begin{tabular}{|c|c|c|}
\hline $\begin{array}{l}\text { Guiding Light 3: Kindling the spark of } \\
\text { light and keeping it glowing } \\
\text { Generating a shared understanding of } \\
\text { what it is that lights people's fire and } \\
\text { finding ways for people to get energy } \\
\text { from each other's different light sources } \\
\text { (priorities, values, beliefs). Helping } \\
\text { ourselves and others to take the risk and } \\
\text { harness the learning from } \\
\text { disappointments alongside delights. }\end{array}$ & $\begin{array}{l}\text { Manley et al., 2011; Wong and Cummings, 2007; The } \\
\text { King's Fund, 2012; Best et al., 2012; Manley and } \\
\text { Titchen, 2016; Akhtar, 2016; Adamson et al., 2011; } \\
\text { Sharp, 2018. }\end{array}$ & $\begin{array}{l}\text { commitment, wellbeing, staff satisfaction \& retention } \\
\text { - Improved confidence to speak up, self-awareness, and empowerment } \\
\text { leading to increased skills, improved relationships, and career development } \\
\text { Teams are healthy, effective and empowered with cultures of active learning, } \\
\text { engagement, reflection and adaptation. } \\
\text { Have a strong team commitment to better practice, creativity, innovation and } \\
\text { improving performance. }\end{array}$ \\
\hline $\begin{array}{l}\text { Guiding Light 4: Lighting up the known } \\
\text { and the yet to be known } \\
\text { Aspiring to be a source of steadiness in } \\
\text { the midst of change by: Sharing } \\
\text { information on what is known and } \\
\text { stable Showing a level of comfort } \\
\text { engaging with uncertainty; and valuing } \\
\text { that what will light the way forward will } \\
\text { be found in relationships which facilitate } \\
\text { flexible and creative approaches that } \\
\text { may differ from action plans, risk } \\
\text { aversion strategies and hierarchical } \\
\text { rules. }\end{array}$ & $\begin{array}{l}\text { Soo Young, 2017; Edmonson, 2010; Hewison and } \\
\text { Morrell, 2014; Cummings et al, 2008; Karimi et al., } \\
\text { 2017; Hurlock- Chorostecki, C., \& McCallum, 2016; } \\
\text { Stavrianopoulos, 2012; Hutchison and Jackson, 2013; } \\
\text { Bender et al., 2017; NHS England, 2017; Dewar and } \\
\text { Cook, 2014; Best et al., 2012; Akhtar et al., 2016; } \\
\text { Manley, 2011; Manley et al., 2008; Plsek and Wilson, } \\
\text { 2001; deZulueta, 2016; Gottlieb, 2017; Sharp, 2018. }\end{array}$ & $\begin{array}{l}\text { People experience better patient, family healthcare outcomes, quality and } \\
\text { satisfaction } \\
\text { Organisations demonstrate } \\
\text { - Improved outcomes for patients/clients, staff and families with regards to } \\
\text { quality, safety, performance, healthy teams, } \\
\text { - Improved services and delivery, } \\
\text { Improved staff retention and stability, and staff commitment aligned with } \\
\text { the qualities of a learning organisation }\end{array}$ \\
\hline
\end{tabular}




\begin{tabular}{|l|l|l|}
\hline $\begin{array}{l}\text { Guiding Light 5: Constellations of } \\
\text { connected stars }\end{array}$ & \\
$\begin{array}{l}\text { Tuning into local resources, networks, } \\
\text { communities and recognising where } \\
\text { there is the potential for enhanced } \\
\text { futures through collective action. } \\
\begin{array}{l}\text { Fostering ways of connecting together } \\
\text { which maximise the possibilities for this } \\
\text { collective action. Responding to the } \\
\text { unique nature of the local context and } \\
\text { practicing adaptability in order to tap } \\
\text { into the distinctive riches }\end{array}\end{array}$ & $\begin{array}{l}\text { Soo Young, 2017; Hewison and Morrell, 2014; The } \\
\text { King's Fund, 2012; Manley et al., 2008; Sharp, 2018. }\end{array}$ & System \& Social capital identified as a resource for system change \\
\hline
\end{tabular}


Figure !: Context, Mechanisms and Outcomes Relationships

\begin{tabular}{|l|l|}
\hline \multicolumn{2}{|l|}{ Context, mechanisms and Outcomes Clarified } \\
\hline $\begin{array}{l}\text { Context } \\
\text { (What works) }\end{array}$ & $\begin{array}{l}\text { different care settings, clinical care, community care, hospital care, } \\
\text { maternity care, residential and nursing home care, primary care, } \\
\text { intermediary care social care, organisations, communities, multi- } \\
\text { professional team environment, culture, systems and processes, } \\
\text { interpersonal and social relationships, multi-professional, technological } \\
\text { factors, economic conditions, enablers, education, }\end{array}$ \\
\hline $\begin{array}{l}\text { Mechanisms } \\
\text { (Why) }\end{array}$ & $\begin{array}{l}\text { how things work, what works, why does it work, triggers, what has to be in } \\
\text { place to facilitate mechanism, does the context affect/impact how or why } \\
\text { the process works, what enablers facilitate, }\end{array}$ \\
\hline Outcome & $\begin{array}{l}\text { What is the impact/outcome? } \\
\text { What are the indicators of impact/outcome? }\end{array}$ \\
\hline $\begin{array}{l}\text { For whom } \\
\text { does it work }\end{array}$ & $\begin{array}{l}\text { Identify how the mechanism and outcome impacts on an individual, team } \\
\text { and /or organisation }\end{array}$ \\
\hline
\end{tabular}


Key term Nurse leadership searched alongside three themes

Date parameters: $2010-2018$

Databases: Cinahl, Medline, SocIndex, Health Source: Nursing/Academic Edition

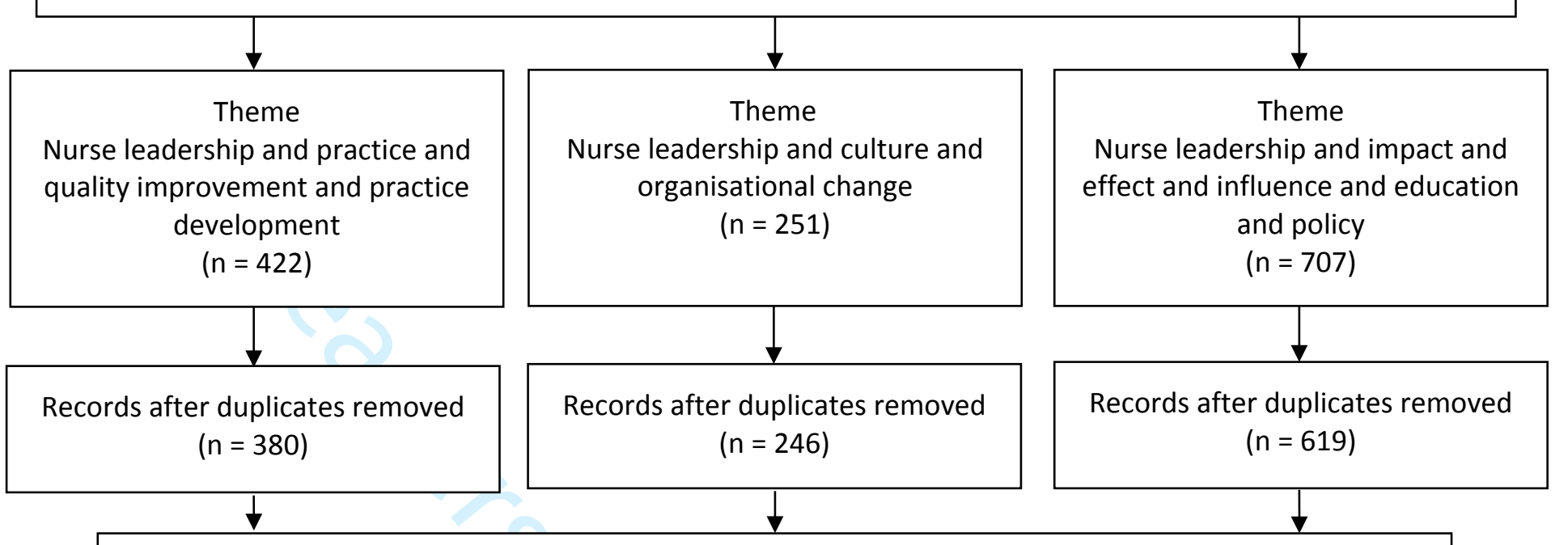

Records after duplicates removed from three themes

$$
\text { ( } n=853)
$$

Search strategy further refined to include key terms only in the title and abstract of the 853 papers and screened to determine which were relevant in relation to meeting the objectives of the review

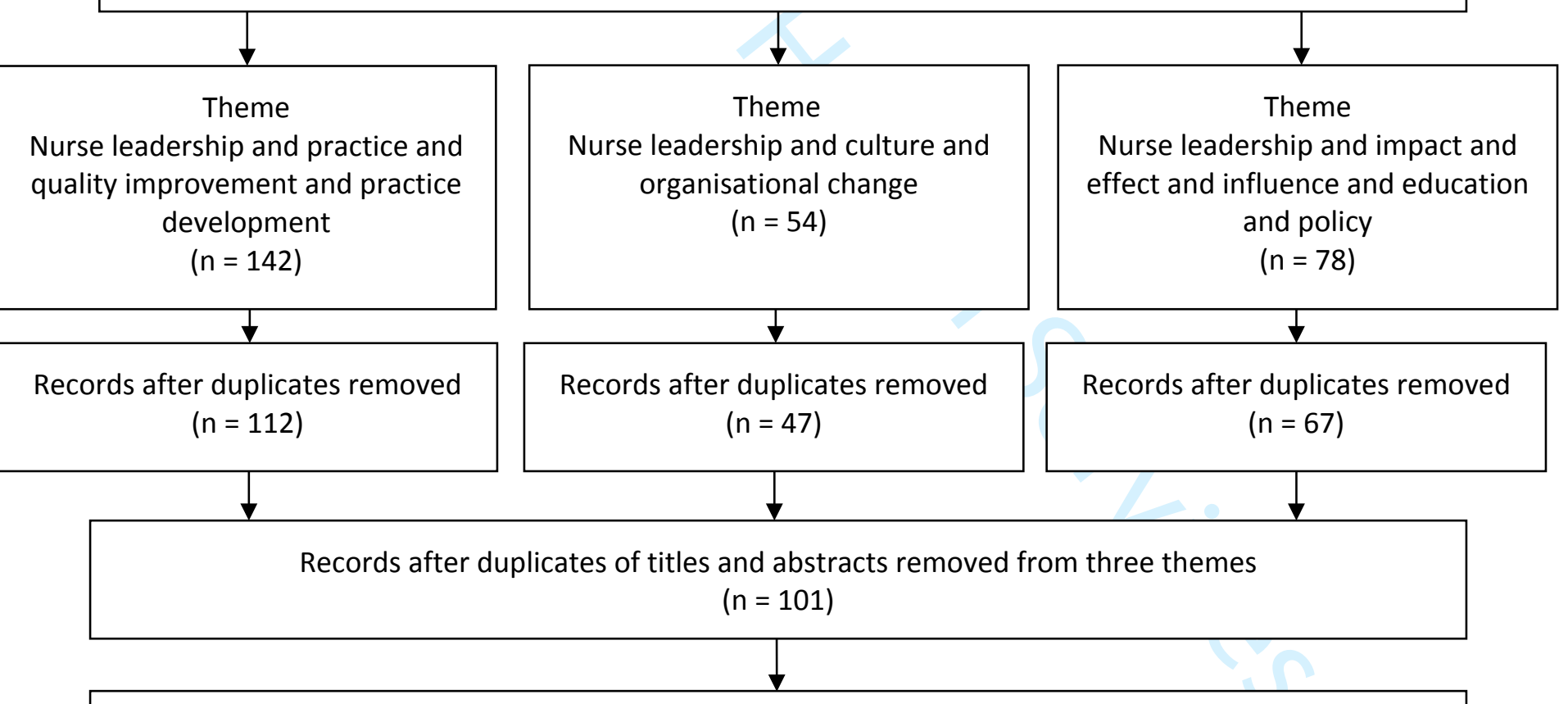

Key authors and grey literature in the field of nurse leadership were identified whilst reviewing the literature and the reference lists of relevant papers screened for secondary sources leading to an additional 32 papers being included in the realistic evaluation of the literature

$$
(n=133)
$$

133 papers reviewed with the context, mechanisms and outcomes included in a realistic evaluation of the literature 


\section{Figure III Composite of images chosen by participants and the conversations this sparked about leadership Phase 3 Workshops}

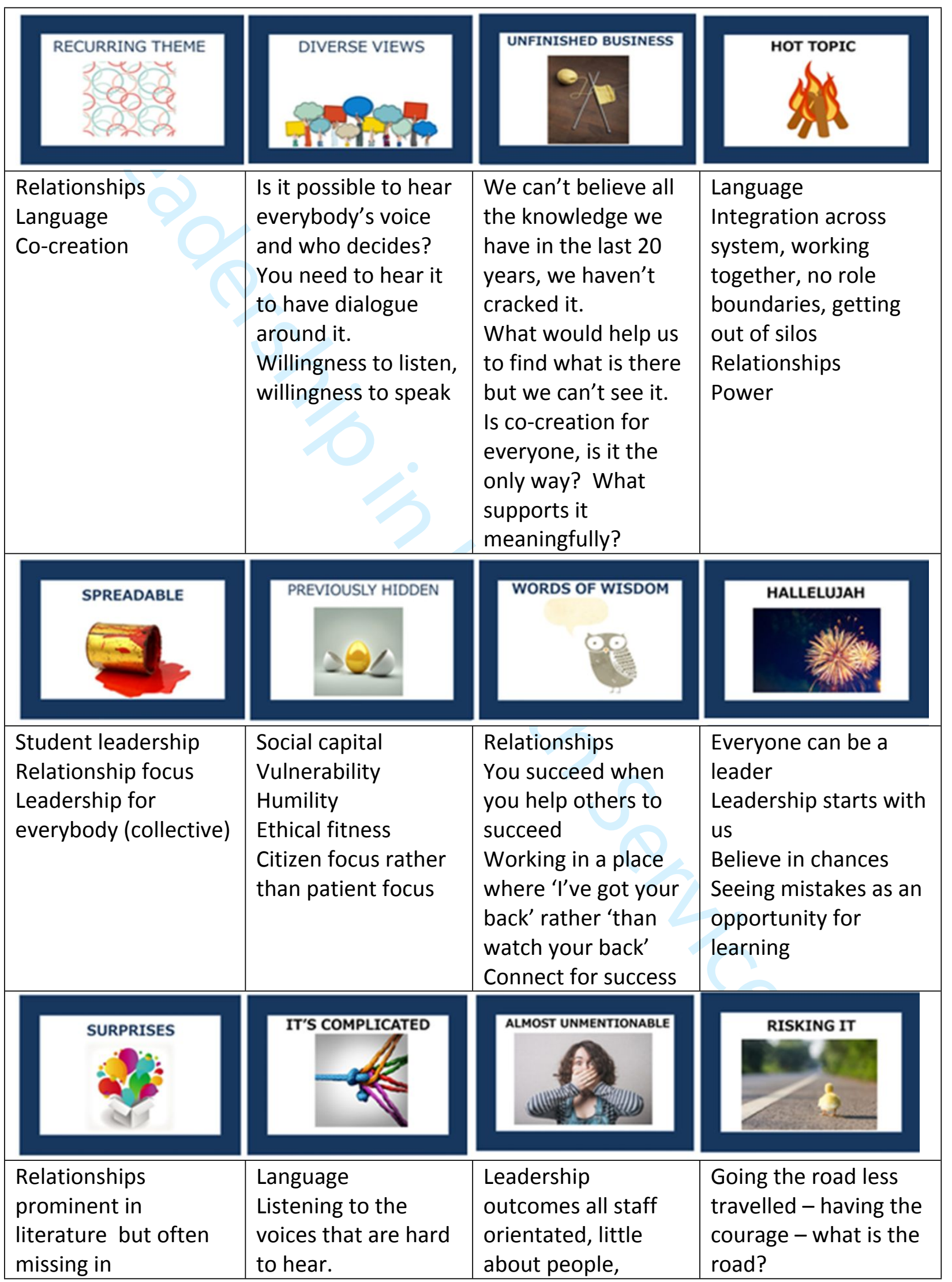




\begin{tabular}{|l|l|l|l|}
\hline $\begin{array}{l}\text { educational/caring } \\
\text { context } \\
\begin{array}{l}\text { Leadership is ways of } \\
\text { being }\end{array}\end{array}$ & $\begin{array}{l}\text { Everything is } \\
\text { intertwined } \\
\text { Relationships }\end{array}$ & $\begin{array}{l}\text { family, citizens as } \\
\text { leaders. }\end{array}$ & $\begin{array}{l}\text { Focussing deeply on } \\
\text { relationships - one } \\
\text { step at a time }\end{array}$ \\
\hline
\end{tabular}


Figure iV: An appreciative 360 assessment and reflection tool.

360 degree feedback form by Dewar (2011) is licensed under the Creative Commons Attribution-NonCommercial-ShareAlike 4.0 International License. To view a copy of this license, visit http://creativecommons.org/licenses/by-nc-sa/4.0/.

\section{Appreciative Feedback for Me. Name:}

I would be grateful if you could consider the following questions and make comments. (If there are questions you do not feel you can answer then leave blank). Do try to be as honest as you can to help me to learn and develop. If it is more helpful to discuss this with me rather than sending the form - please let me know. Try to think about specific examples in your feedback. Thank you in anticipation.

\begin{tabular}{|c|c|}
\hline Area of exploration & Feedback \\
\hline \multicolumn{2}{|c|}{ Guiding Light 1: The light between us as interactions in our relationships } \\
\hline \multicolumn{2}{|l|}{$\begin{array}{l}\text { What feedback would you like } \\
\text { to give me about the way that I } \\
\text { communicate with you? }\end{array}$} \\
\hline \multicolumn{2}{|l|}{$\begin{array}{l}\text { What feedback would you like } \\
\text { to give me about the way I } \\
\text { communicate with and engage } \\
\text { others? }\end{array}$} \\
\hline \multicolumn{2}{|l|}{$\begin{array}{l}\text { Have you seen me being } \\
\text { courageous at work? If so } \\
\text { what was this? }\end{array}$} \\
\hline \multicolumn{2}{|c|}{ Guiding Light 2: Seeing people's inner light } \\
\hline \multicolumn{2}{|l|}{$\begin{array}{l}\text { What aspects about how I am } \\
\text { at work do you think people } \\
\text { value? }\end{array}$} \\
\hline \multicolumn{2}{|l|}{$\begin{array}{l}\text { What would you say about } \\
\text { how I am with emotions, my } \\
\text { own and others? }\end{array}$} \\
\hline \multicolumn{2}{|l|}{$\begin{array}{l}\text { How do I support people } \\
\text { during stressful or emotional } \\
\text { experiences? }\end{array}$} \\
\hline \multicolumn{2}{|l|}{$\begin{array}{l}\text { How do you think I respond to } \\
\text { difficult or sensitive situations } \\
\text { with others? }\end{array}$} \\
\hline \multicolumn{2}{|l|}{$\begin{array}{l}\text { In what ways do I give } \\
\text { everyone a chance to } \\
\text { participate or feel included? }\end{array}$} \\
\hline \multicolumn{2}{|l|}{$\begin{array}{l}\text { What do I do to help create a } \\
\text { safe environment for everyone } \\
\text { to flourish? }\end{array}$} \\
\hline $\begin{array}{l}\text { What would you say about my } \\
\text { ability to take on board other } \\
\text { people's perspectives? }\end{array}$ & $U$ \\
\hline \multicolumn{2}{|c|}{ Guiding Light 3: Kindling the spark of light and keeping it glowing } \\
\hline $\begin{array}{l}\text { What feedback can you give } \\
\text { me about my ability to notice } \\
\text { and build on people's } \\
\text { strengths? }\end{array}$ & \\
\hline
\end{tabular}




\begin{tabular}{|c|c|}
\hline $\begin{array}{l}\text { What would you say about my } \\
\text { ability to work with and } \\
\text { collaborate with others? }\end{array}$ & \\
\hline $\begin{array}{l}\text { What would you say about my } \\
\text { ability to show support and } \\
\text { appreciation to people? }\end{array}$ & \\
\hline $\begin{array}{l}\text { Can you give me an example } \\
\text { when you have noticed that I } \\
\text { have shared learning/new } \\
\text { insights with others? }\end{array}$ & \\
\hline Guiding Light 4: Lighting up t & he known and the yet to be known \\
\hline $\begin{array}{l}\text { What feedback can you give } \\
\text { me about my ability to remain } \\
\text { calm and steady in complex } \\
\text { and unpredictable situations? }\end{array}$ & \\
\hline $\begin{array}{l}\text { When I am communicating } \\
\text { with you and others, what } \\
\text { would you say about my ability } \\
\text { to hold off in making } \\
\text { assumptions and ask } \\
\text { questions? }\end{array}$ & \\
\hline $\begin{array}{l}\text { What would you say about my } \\
\text { ability to help people to come } \\
\text { up with their own ideas? }\end{array}$ & \\
\hline $\begin{array}{l}\text { What would you say about my } \\
\text { ability to constructively } \\
\text { challenge or stretch people? }\end{array}$ & \\
\hline $\begin{array}{l}\text { What feedback can you give } \\
\text { me about how I am and how I } \\
\text { enable others to be flexible } \\
\text { and creative with change and } \\
\text { complexity? }\end{array}$ & \\
\hline Guiding Light 5: Constellatior & s of connected stars \\
\hline $\begin{array}{l}\text { What do I do that helps to build } \\
\text { networks? }\end{array}$ & (2) \\
\hline $\begin{array}{l}\text { What feedback would describe } \\
\text { how I connect internally and } \\
\text { external with others to achieve } \\
\text { collective action? }\end{array}$ & \\
\hline
\end{tabular}

\begin{tabular}{|l|l|}
\hline General \\
\hline $\begin{array}{l}\text { If you could choose one word } \\
\text { to describe me what would it } \\
\text { be? }\end{array}$ \\
\hline $\begin{array}{l}\text { If there was one thing that you } \\
\text { feel I could do more of what } \\
\text { would this be? }\end{array}$ \\
\hline
\end{tabular}

Please could you complete this form by and email/send this this back to me at ...... 360 degree feedback form by Dewar (2011) is licensed under the Creative Commons Attribution-NonCommercial-ShareAlike 4.0 International License. To view a copy of this license, visit http://creativecommons.org/licenses/by-nc-sa/4.0/. 